\title{
Utopia and Civilisation in the Arab Nahda
}

by

Peter Hill

St John's College

Thesis submitted in partial fulfilment of the requirements for the degree of Doctor of Philosophy

Department of Oriental Studies, University of Oxford

December, 2015 


\section{Acknowledgements}

While working on this thesis I received generous financial aid from the Arts and Humanities Research Council (UK) and St John's College, Oxford in the form of AHRC-Lamb and Flag Studentships; and latterly from Christ Church, Oxford, via a Junior Research Fellowship. The Institut français du Proche-Orient, Beirut, kindly provided me with a base in Lebanon for the 2013-14 academic year.

Many others, in many ways, have helped me to complete this project. I should like in particular to thank my supervisor Mohamed-Salah Omri, who has overseen the project throughout; and Robin Ostle, who has offered invaluable advice at various stages. I would like to thank those who participated in the Oxford Nahda Workshop in May 2015, and especially my co-organisers, Hussein Omar, Nadia Bou Ali and Ezgi Ulusoy Aranyosi; and in addition the following people for their comments and advice on the project, and in some cases for sharing unpublished work: Nicole Khayat, Adam Mestyan, Joanna Innes, Maha Abdel Megeed, Claire Savina, Geert Jan Van Gelder, Mohammed Afifi, Şeyma Afacan, Laurent Mignon, Samah Selim, Zachary Foster, Amina Rashid and Sayed El Bahrawi. I am also grateful to my many teachers of Arabic, in Syria, England, and Lebanon; and to the library staff at Oxford, the American University in Beirut, and Dār al-Kutub al-Qawmiyya in Cairo.

For this, corrected version of the thesis I thank also my two examiners, Marilyn Booth and Khaled Fahmy, for their helpful comments and suggestions.

\section{Note on the text}

All translations are my own, unless otherwise stated. For each Arabic quotation the original 
is given in a footnote, immediately following the reference, and in its original form, which will not necessarily conform to modern orthographic conventions. Arabic names, titles, etc, are transliterated using the Library of Congress system. Names with accepted Romanised versions and a few frequently-recurring terms are given in simplified forms. 


\begin{abstract}
This doctoral thesis explores the contexts of utopian writing and thinking in the Nahda, the Arab 'Awakening' of the long nineteenth century. Utopian forms of social imagination were responses to fundamental changes in the societies of the Arab-Ottoman world brought about by integration into a capitalist world economy and a European-dominated political system. Much Nahda writing was permeated by a sense of a 'New Age' opening and of wide horizons for future change - and this was not simply illusory, but a direct response to actual and massive changes being wrought in the writers' social world. My study focusses on Egypt and Bilād al-Shām in the middle decades of the nineteenth century, from the early 1830 s to the mid-1870s. An initial chapter offers a definition of the social classes and groups which contributed to the Nahda in these years - such as the Beiruti bourgeoisie and the EgyptianOttoman official class - drawing on the work of Arab Marxists such as Mahdī 'Āmil and social historians such as Bruce Masters. The following chapters deal in detail with writings produced by three distinct cultural formations within the Nahda movement, and with different aspects of their social imagination. Chapter 2 examines the discourse of civilisation (tamaddun) through the work of the Beiruti writers Khalīl al-Khūrī and Buṭus al-Bustānī in the $1850 \mathrm{~s}$ and 1860s. Chapter 3 deals with Nahda writers' sense of their place within the European-dominated world, mainly through translations of geography books made by Rifā'a al-Ṭahțāwī in Mehmed Ali's Egypt in the 1830s and 1840s. Chapter 4 examines the utopian aspirations of the Nahda, through a close study of the major utopian literary work of the period, Fransīs Marrāsh’s Ghābat al-Haqq (The Forest of Justice, 1865). Finally, a conclusion places my study in relation to other recent work in the field of 'Nahda studies'.
\end{abstract}




\section{Table of Contents}

Acknowledgements...........................................................

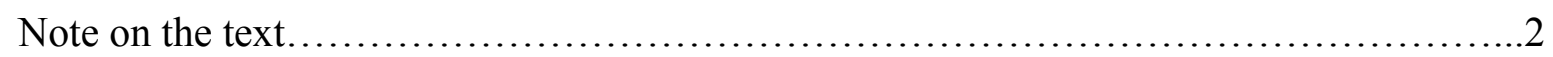

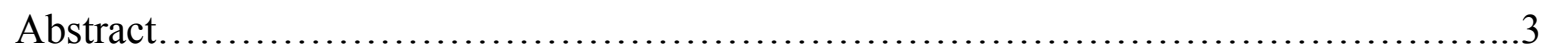

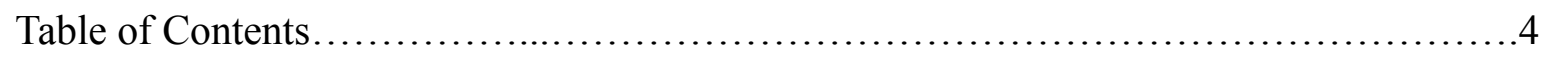

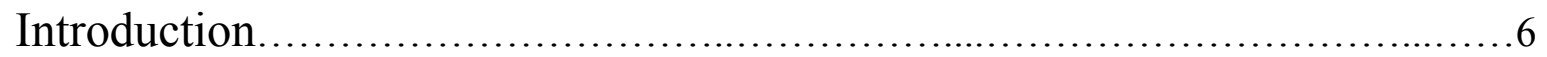

Chapter 1: Who Made the Nahda? .............................................20

'Class' and 'mode of production' in the Arab-Ottoman world...........................26

A. The Groups that Made the Nahda .................................................. 31

The Beiruti bourgeoisie................................................ 32

Bilād al-Shām: bourgeois and notables..................................... 37

Egypt: officials, teachers and students ................................... 40

Patterns of patronage.......................................................43

'Hidden categories' in the nahda public, and summary .......................46

B. Class Conflict and 'Adaptation' ..............................................48

Egypt: the Arab 'technicians' in an Ottoman bureaucracy........................49

Bilād al-Shām: the 1850-61 conflicts..........................................55

Bilād al-Shām: the restoration of order.....................................58

The place of Beirut in the post-1860 order.................................662

A capitalist class? ......................................................64

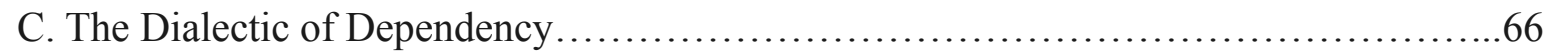

Hegemony, collaboration, and resistance...................................66

The merchants: compradors or 'bourgeoisie in their own right'? .................68

The reforming officials: between Europe and the dynasty........................75

Towards the twentieth century: 'class differentiation' ............................... 77

Conclusion, or a further hypothesis........................................... 80

Chapter 2: The Discourse of Civilisation........................................ 84

Prologue: Khalīl al-Khūrī's introduction to Hadīqat al-Akhbār .........................87

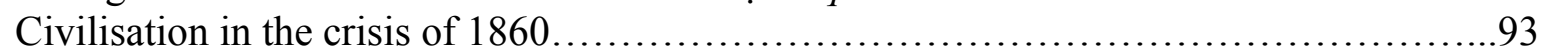

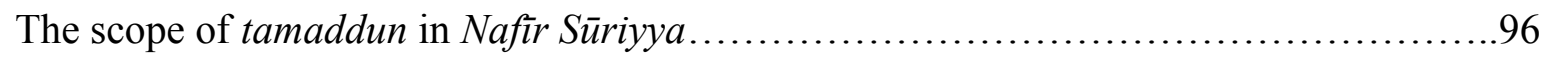

Tamaddun for whom?............................................................. 101

Tamaddun as external or internal standard?...................................... 108

Consolidation in the 1860s; Civilisation and Society................................. 115

Class confidence: Beirut 1869.................................................. 122

The discourse of civilisation: in whose terms? ..................................... 126 


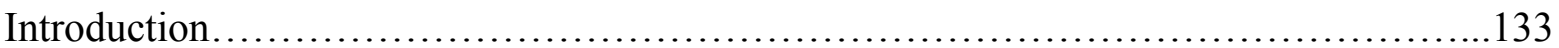

Among the Geographers........................................................... 137

The Old Geography and the New...............................................144

'A picture of what his rule contained': a geography of Mehmed Ali's domains..............148

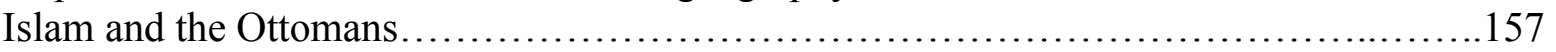

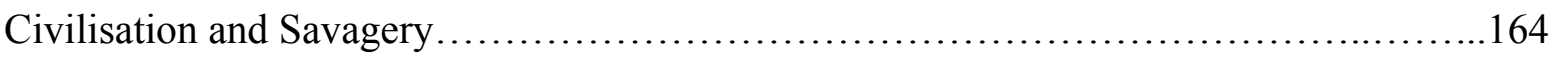

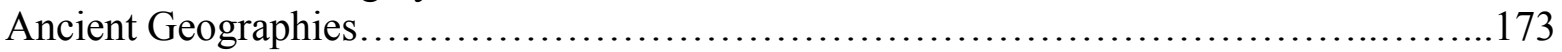

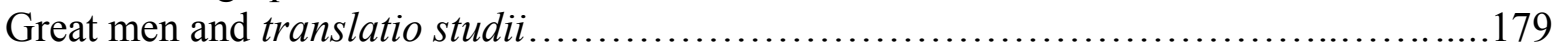

Through Western eyes: the foreign news reports of Hadīqat al-Akhbār.................183

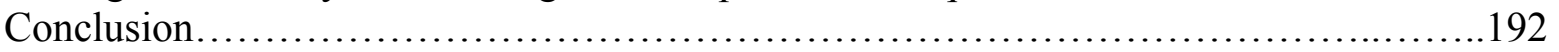

Chapter 4: An Arab Utopian..................................................197

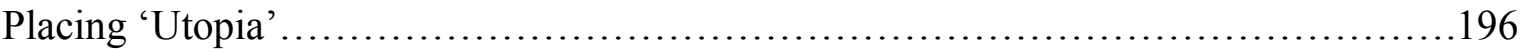

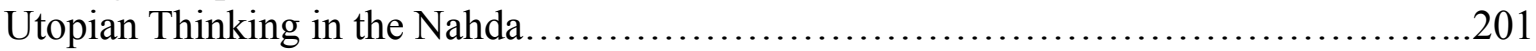

In the Forest of Justice......................................................... 210

Allegory, Dialogue and Narrative: the Framing of the Utopia..........................215

The Natural and the Moral; Law and Freedom......................................221

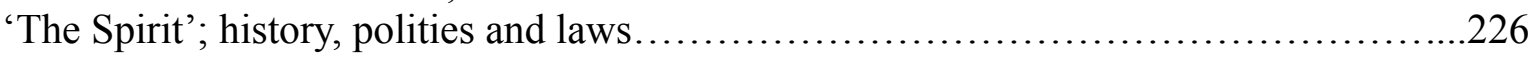

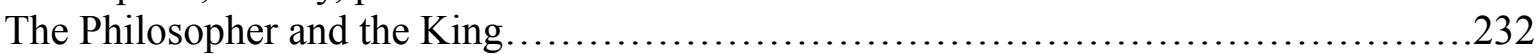

Discontents: Barbarous Civilisation............................................ 243

Conclusion: Nahda Studies and Material Histories..............................252

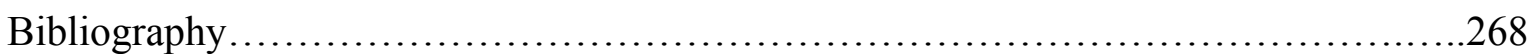




\section{Introduction}

On 1 January, 1858, the first number of a new journal, Hadīqat al-Akhbār (The Garden of News), was issued from the Syrian Press in Beirut. The first privately financed Arabic newspaper in the Arab lands, it was edited by the young Syrian poet Khalīl al-Khūrī. The date chosen for its launch was symbolic: as well as the start of a newspaper, it announces the beginning of a 'New Age'. This is in fact the title of a poem by Khūrī, included in his introductory letter to the readers. The poem begins:

\section{The New Age}

Arise: see how the universe orders itself by design; and witness the age, how it smiles with refinement!

Khūrī's introductory letter goes on to call on the 'people of the country, young men of the homeland [...] stirred by cultural honour, to 'storm forth to acquire knowledge and science'. ${ }^{1}$

This cultural and intellectual call to arms, in 1858, took place in the midst of, and indeed was one component of, an era of rapid and astonishing change for the Arab lands of the Ottoman Empire. Beirut, a mere village in the 1820 s, had grown enormously as a trading centre; in 1858 it was well on its way to supplanting Tripoli and Sidon as the principal port of Syria. Steamships (and soon, in the early 1860s, the telegraph) were drawing Beirut ever closer to the Ottoman imperial centre and to Western Europe, particularly France. The Ottoman government had announced, in 1839 and again in 1856, decrees implying radical new changes in the Empire: the founding documents of the Tanzimat or Ottoman reform. These had been preceded by the similar reformist efforts of Mehmed Ali, the Pasha of Egypt, and those of his son Ibrahim's government of Syria, which his troops occupied from 1831 to 1841. More efficient and determined taxation, military conscription, expanded bureaucracies, the use of European personnel and techniques, characterised these state reforms. They were

1 Hadīqat al-Akhbār, no. 1; see below, Chapter 1, for Arabic. 
accompanied by new cultural developments in Arabic (as well as in Ottoman Turkish and other languages of the Empire): the printing press of Bulaq in Cairo, which issued many translations of European works as well as Arabic works from the 1830s to the 1850s; the American Protestant missionaries' press in Beirut, and the missionary-sponsored Syrian Society for the Acquisition of Sciences and Arts, founded in 1847; the plays staged in Beirut in the 1850s; and now Khūrî's newspaper and the Syrian Press, on which it was printed.

Of all this Khūrī, in 1858, would have been aware. And when we look back now with the benefit of hindsight we can see that his expectations of still greater developments to come, as the 'New Age' opened, were amply justified. Over the next fifteen years, Beirut's rise continued, stimulated particularly by French demand for Mount Lebanon silk; Egypt saw a cotton boom; the implementation of the Tanzimat continued, with new commercial and land laws and an expanding bureaucracy. Hadīqat al-Akhbār was joined by four other major Arabic periodicals in Beirut alone, and many more elsewhere, publishing, as well as news reports, new kinds of addresses to the public, and serialised narrative fiction. There were more learned societies, schools and colleges, a League for the Publication of Arab Books, theatres and libraries. ${ }^{2}$ There was, of course, a darker side to these developments. Mehmed Ali's power and sponsorship of culture were built on the intensified exploitation of the Egyptian peasantry in the fields and in the army, and inextricably bound up with wars of conquest. The rise of Beirut was punctuated by the sectarian violence of 1860 in Lebanon and Damascus, and the perhaps greater violence of the Ottoman 'restoration of order'. The sustained and fruitful contact of intellectuals with European culture was enabled by the increase European in imperial power and exploitation in the region, culminating in the imposition of direct European control, from 1882 in Egypt and 1919 in Bilād al-Shām. But from the perspective of intellectuals like Khūrī, and the Beiruti merchants or Ottoman

2 The best detailed account of these developments is probably still Jurjī Zaydān, Tārīkh Ādāb al-Lugha al'Arabiyya, vol. 4: al-Nahḍa al-Akhīra, 4 vols. (Cairo: Dār al-Hilāl, 1914). 
functionaries who were their patrons, this was indeed a 'New Age' of prosperity for the Ottoman-Arab lands, and for Arabic culture.

The temporal limits of this study stretch, either side of Khūrī's announcement of 1858, from the early 1830 s to the mid-1870s. This was a period of the rise to prominence of new groups within these Arab-Ottoman lands around the Mediterranean: the merchant capitalists of Bilād al-Shām, the modern bureaucracy of Egypt (and Tunisia), a 'secular' or at any rate not primarily religious kind of intellectual. This was accompanied by growing cultural innovation, or appropriation of European models: printing, newspapers, new forms of writing. But the groups involved in the 'Nahda' of this period were still relatively small in number, with considerable continuity from older elites. It is marked off from the later period by the watershed which Sabry Hafez places in the 1870s, after which the press and reading public expanded far more rapidly. ${ }^{3}$ After this date, still newer groups rose to prominence, constituting an expanding 'middle' or 'lower-middle' class which was a definite presence by the turn of the century. This watershed in the 1870 s requires particular emphasis, perhaps, as many studies tend to assimilate the middle decades of the nineteenth century, as prelude, into an account of a 'late Ottoman' period centred essentially on the 1880 s to 1910 s, or even an account of the 'modern' Middle East or Arab world, centred on the twentieth century. This has led, rather too often, to a teleological reading of history in which the earlier decades are scanned for precursors of later developments, rather than being studied in their own right. My concentration on the middle decades of the century represents, then, an attempt to escape one of the disadvantages of historical hindsight: the temptation to believe that a certain outcome was predetermined, and hence not to see the openness of the historical processes being studied. ${ }^{4}$

3 The Genesis of Arabic Narrative Discourse: A Study in the Sociology of Modern Arabic Literature (London: Saqi, 1993), 63-6, 83.

4 For an argument along these lines, see E. P. Thompson, 'The Peculiarities Of The English', Socialist 
But while its temporal reach is more limited than is often the case for studies of the Arab Nahda, this thesis's frame of geographical reference aims to be broader than has sometimes been the case in studies of the Arab-Ottoman lands. By this I mean that I have tried to relate the specific processes I am studying, which are of course grounded in this region, to wider questions, not just of Middle Eastern but of world history. This is part of an effort to break out from a certain insularity or particularism which has often affected studies of the Middle East (or the Arab world, or Ottoman Empire), and which tends to regard phenomena of the region either as sui generis, without counterparts elsewhere, or as relating to only one part of the world outside the region: Europe, or 'the West'. I cannot claim to have offered, here, a general comparative framework or typology. But I have sought to place the Nahda within a context, not just of the Middle East or its dialogue with 'Europe', but of a general development of the globe - though a globe which was, in this period, European-dominated, and which included many developments which were indeed locally specific. ${ }^{5}$ In this I follow the lead, in one sense, of those, like Immanuel Wallerstein or Samir Amin, who have attempted to generalise on a global level about the 'world-system' of capitalism and the conditions of imperialised formations within it. ${ }^{6}$ But I have tried to avoid the flattening of local differences and schematising tendencies to which these attempts were prone. The 'New Age' which Khūrī saw dawning from Beirut could also be perceived - but with important differences - from Calcutta, Shanghai, or Buenos Aires.

The specific aspect of the Nahda on which I concentrate in this thesis is its social

Register 2 (19 March 1965); and the comment of Sumit Sarkar, Writing Social History (Delhi: Oxford University Press, 1997), 79.

5 I have argued this point at greater length elsewhere: 'Revisiting the Intellectual Space of the Nahḍa (Eighteenth-Twentieth Centuries)', Les Carnets de l'Ifpo, 5 June 2014, http://ifpo.hypotheses.org/6013.

6 Immanuel Wallerstein, 'The Ottoman Empire and the Capitalist World-Economy: Some Questions for Research', Review (Fernand Braudel Center) 2, no. 3 (Winter 1979): 389-98; Samir Amin, Unequal Development: An Essay on the Social Formations of Peripheral Capitalism (Hassocks: Harvester, 1976). 
imagination - its writing and thinking about civilisation and related concepts, in a range of forms which included utopian modes. These can be seen as direct responses to the massive changes taking place in the writers' and readers' actual social worlds. From Khūrī’s proclaimed 'New Age' to images of other worlds taken from European geography books, from translated fictional works such as Defoe's Robinson Crusoe or Fénelon's Les aventures de Télémaque to reinventions of the earlier Arabic 'utopian' tradition of Mirrors for Princes, these kinds of writing and thinking form a major, though often rather overlooked, aspect of the period from the early 1830 s to the mid-1870s.

The object of this study is to return these specific forms of cultural production - which are in fact the surviving evidence of specific kinds of cultural practice, carried out by then living readers, writers, performers, auditors, and other participants - to their social conditions of production - to use the terminology of the Welsh cultural critic Raymond Williams, whose work is one major model for what I am attempting here. ${ }^{7}$ I am studying Khūrī's 'New Age' in both its aspects: the sense of a new age and the possible forms it might take, as projected in writing of the time; and the rapidly changing conditions in the Arab-Ottoman lands and the wider world to which these imaginings were a response. This is a study, then, both of the cultural and intellectual movement which became known, later, as the Arab 'nahḍa' awakening or renaissance - and of the conditions and social formations which made it possible, over the middle decades of the nineteenth century.

It has proved necessary, in the process of writing this thesis, to separate out the two aspects, the cultural production and its social conditions, to some extent - though I hope that their interpenetration at every level will be apparent to the reader. For this reason my first chapter

7 'Base and Superstructure in Marxist Cultural Theory', in Culture and Materialism: Selected Essays, 11 (London: Verso, 2005), 31-49; see also his Marxism and Literature (Oxford: Oxford University Press, 1977). 
stands somewhat apart from the succeeding three, as it attempts to define the social groupings and forces which contributed to and made possible the cultural movement of the Nahda, rather than engaging directly, like the other three chapters, with the products of the cultural movement itself. This first chapter sets out to answer the question: who made the Nahda - what social groups, and how are they best defined? My answer takes the form of a running argument with the preeminent Lebanese Marxist theorist of the 1970s, Mahdī 'Āmil, who elaborated his theses of the colonial mode of production and the Nahda as the production of an Arab bourgeoisie fundamentally dependent on European colonialism.

Working between these formulations and the evidence presented by social historians of the Arab Ottoman world in the nineteenth century, I present a modified hypothesis as to the class character of the Nahda. I retain the concepts of class and mode of production as tools of analysis, with additional theoretical clarifications from other writers within the Marxist tradition, such as Robert Brenner and Perry Anderson. I follow historians such as Jens Hanssen, Muhammad Jamal Barut and Fruma Zachs in arguing that the cultural movement known as the Nahda was the product of specific social classes, and further argue that one of these classes, the bourgeoisie of Beirut, can be defined, from the 1860s at least, as a capitalist class. The class responsible for the Egyptian 'translation movement' into Arabic under Mehmed Ali in the 1820s-40s I regard as a non-capitalist class, dependent on a modification - admittedly a drastic one - of a precapitalist mode of production, by Mehmed Ali's innovatory regime. The key class in promoting the Nahda in Bilād al-Shām ('greater Syria') beyond Beirut and its immediate hinterland I see as a class of merchants affiliated to the Beiruti bourgeoisie but still operating in a largely non-capitalist economy and a society dominated by older kinds of 'notable'. The penetration of the region by a Europeandominated world market, and the growth of 'modern' forms of state organisation and of 
cultural practice, were determining factors for all of these 'new social classes', and their conflicts with older dominant groups in the region. But I dissent from Amel's definition of these classes as purely 'colonial' in nature, wholly dependent upon European imperialism: I consider that they must be seen, rather, as caught up in a dialectical process of subordination to European or Western interests, in which they had, in this period, a limited autonomy which was not unimportant. Classes such as the Beiruti bourgeoisie can then rightly be seen as being locally hegemonic, though subordinated to Europeans within the wider global order.

In the succeeding three chapters I then go on to examine the cultural production and practices of the Nahda movement: specifically its social imagination, and the ways in which those participating in it thought of 'civilisation' (tamaddun) and the 'New Age', including projections of a utopian kind. I see the 'Nahda' - a problematic term, but one I adopt for convenience - as a movement made up, through these middle decades of the nineteenth century, of distinct though interrelated formations. By this I mean 'cultural formations' in the sense defined by Raymond Williams: 'most recognizable as conscious movements and tendencies (literary, artistic, philosophical or scientific)' but often also 'articulations of much wider effective formations' ${ }^{8}$ The relations between such formations and social institutions or classes are, for Williams, 'highly variable and often oblique': a formation cannot be assumed to be a direct expression (or 'reflection') of the interests or consciousness of a particular class. In the cases examined here, I believe, nonetheless, that we can discern very close relations between the formations composing the Nahda and the distinct though allied social classes defined in Chapter 1.

I examine three such formations. The first and most dominant for the period as a whole had its centre of gravity in Beirut, among writers such as Khalīl al-Khūrī and Buṭrus al-

$8 \quad$ Marxism and Literature, 119. 
Bustānī, from the 1850 s to the early 1870 s. My second chapter concentrates on this formation, and specifically on its role in forming the new discourse and vocabulary of 'civilisation', widely recognised as central to this phase of the Nahda. Using methods inspired by those of Raymond Williams, in studies such as Culture and Society and Keywords, I trace this discourse from a still emergent phase in the 1850s, with Khūrī's 'New Age' and call for cultural revival, through to the writings of the Syrian writer, educator, and convert to Protestantism Buṭus al-Bustānī in the 1860s. In his Nafir Suriyya (The Syrian Clarion), we have a direct response to the violent crisis of $1860-61$, which was also a decisive phase in the crystallisation of the new discourse and vocabulary of 'civilisation' (tamaddun), 'homeland' (wațan), 'education' (tahdhīb, tarbiya, and other terms), and the like. I examine the range of this discourse and some of the tensions between different conceptions of the social order which it embodied, at the critical and ambivalent moment of the 1860 crisis, which was both a time of violence, disorder and shame, and the beginning of new opportunities for the Syrian bourgeoisie to which Bustānī belonged. I then turn to a later approach to similar questions, again by Bustān̄̄, in his address 'On the Social Body [or: Society]' of 1869. In the more prosperous and stable environment of the post-1860 settlement in Beirut and Mount Lebanon, I argue that the concept of this part of the region and its people as 'civilised' takes on a settled confidence, as the consciousness of a locally hegemonic class. Yet the evolution of this discourse, though closely determined by these social conditions, could also take the form of a reworking of older Arabic conceptions of society, such as those deriving from Ibn Khaldūn. In this phenomenon - which we see repeated in other writers of the Nahda movement - we can see an instance of the active and selective manner in which a 'tradition' is perpetuated, reshaping resources drawn from the past into an effective 'ratification of a contemporary order'. 9

9 See ibid., 115-7: quotation 116. 
My third chapter is centred on the Egyptian formation around Rifā' a al-Ṭahțāwī and the Arabophone writers, translators and educators in Mehmed Ali's service, which attained its peak of activity rather earlier than the Beiruti formation, in the 1830s and 40s. Again I focus on one aspect of it and the contribution which this made to the wider Nahda: in this case, the translations and rewritings of European geography books made by Tahțāwī, and their role in fashioning a new sense of the place of the Arab-Ottoman lands within an expanded and European-dominated world. This gives me an opportunity to examine, from a cultural angle, the question raised by Mehdi Amel, of the 'dependency' of the social classes involved in the Nahda upon Europe. While postcolonial critics such as Timothy Mitchell and - with qualifications - Shaden Tageldin have tended to argue that cultural dependency on Europe was practically inescapable for Arab intellectuals of the nineteenth century, I argue that this was only part of the story. In the first place, the world in which writers like Tahtậwī were 'placing' themselves and the polities and cultures to which they belonged was wider than just the Arab-Ottoman lands and Europe. In judging themselves and others on the scale of 'civilisation', they could find many instances of peoples - Sudanese blacks or American Indians - considered to be less civilised than themselves, as well as those - notably Europeans - who might be considered, at least in some respects, as more civilised than Egyptians like Ṭahțāwī.

Moreover, European knowledge about the Arab-Ottoman lands themselves - unlike the rest of the world - was not accepted uncritically, but modified according to the experience and knowledge of writers like Ṭahțāwī. European respect for the Ancient world (present in Syria and Egypt) provided one source of Nahda writers' confidence in the civilisational potential of their own societies. Projections of European state or imperial power could be taken over and adapted into projections of innovatory forms of Arab or Ottoman power, in a form of 
translatio imperii: thus the French geographer Malte-Brun's suggestions of the benefits European rule could bestow on Syria was transformed, in Țahțāwī’s reworking, into the suggestion that these benefits were in fact being achieved under Mehmed Ali's dynasty, which was then occupying Syria. In these ways we can see 'dependency' upon Europe, not as absolute, but as one side of a dialectic, the other side of which was composed by more local interests. I follow the question of the place Nahda writers saw themselves as occupying within the world through into the Beirut of the late 1850 s, by way of the foreign news reports in Khalīl al-Khūrī's newspaper Hadīqat al-Akhbār. These covered the world beyond Europe, but to a great extent through European eyes: events such as the Indian Mutiny or the Second Opium War in China were reported via European news accounts, with their attendant ideological assumptions. In relation to the Ottoman-Arab lands themselves, however, local sources were available and preferred. I argue that this ambivalent relationship to Europe was an aspect of the actual interests and positions of both the Egyptian official class under Mehmed Ali and the Beiruti bourgeoisie - as indeed 'dependent' upon contact with Europe, but opposed to unqualified European domination over their own societies. This is one main area where I believe a teleological approach to the middle decades of the nineteenth century, searching for early signs of later developments, has led to a misreading of the period, as the conditions of the 'high imperialism' of the 1880s to 1914 have been projected back onto the distinct era of Palmerstonian, consuls-and-gunboats imperialism, ${ }^{10}$ which contained significant though limited spaces for groups like the Beiruti bourgeoisie to create and imagine their own roles within a European-dominated world.

The third formation, in Aleppo around writers from wealthy Christian families like the Marrāshes and Dallāls, had its own history and identity, but in the 1860s, when my study

10 For a general distinction between the two sets of conditions, see Eric Hobsbawm, The Age of Capital (London: Abacus, 1995), Conclusion. 
touches upon it, was strongly under the influence of the Beirut-centred formation of Bustāni and Khūrī. Similar concerns, with civilisation and barbarism, violent rebellion and state power, science and faith, inflected it; but it was a member of this formation, Fransīs Marrāsh, who created out of these concerns the one major original utopian narrative of the period, Ghäbat al-Haqq (The Forest of Justice, 1865). This forms the major focus of my fourth chapter; in order to deal with it I first lay out a framework for considering utopian writing, drawing on critics such as A. L. Morton, Raymond Williams and Edward Thompson, and situate Ghābat al-Haqq and other Arabic utopias within this. I regard Ghäbat al-Haqq, along with other writings of its time like Tahțāwī’s and Bustān̄̄’s translations of Les aventures de Télémaque and Robinson Crusoe, as among the first examples in Arabic of a new kind of utopian writing: that of capitalist modernity, a phase of history in which massive, rapid social change became not only possible but commonplace.

I then look at the text of Ghābat al-Haqq itself in detail, within the context of Marrāsh's own intellectual development and his circle in Aleppo. I approach it from three main angles: that of the distinction between the natural and the moral or cultural spheres, and the debates between free will and determinism, which Marrāsh engaged with. Second I examine his accounts of religion, human history and polities; and third, the dialogue between the intellectual and the powerful - the philosopher and the King - familiar from older Arabic Mirrors for Princes literature, and reworked in Ghäbat al-Haqq. In all these areas the influence, noted by scholars such as Rotraud Wielandt, ${ }^{11}$ of European Enlightenment thinking is evident - but, unlike Wielandt, I do not regard this as mainly a case of Marrāsh's 'transmission' of the Enlightenment. Rather, it was a reworking of these ideas, in conjunction with older Arabic forms and concepts, and under the pressure of contemporary

11 'Fransîs Fatḥallâh Marrâshs Zugang Zum Gedankengut Der Aufklärung Und Der Französischen Revolution', in The Middle East and Europe: Encounters and Exchanges, ed. G. J. H. van Gelder and Ed de Moor, Orientations, 1 (Amsterdam: Rodopi, 1992), 116-46. 
circumstances - the situation of the Christian merchant class in Aleppo, in alliance with reforming Ottoman governors, and the context of the violent episodes of 1850 and 1860-61 being crucial to Marrāsh's vision of a war between civilisation and slavery.

Finally I turn to a facet of Marrāsh's writing, in Ghābat al-Haqq but more especially in his later work, which bears out one aspect of Raymond Williams's conception of a cultural formation, referred to above. Williams insists that the links between such a formation and social institutions and groups (such as classes) can never be assumed to be direct or automatic: they must always be specified, and must be regarded as variable. In the case of the Nahda movement, as we move beyond the limits of our period and towards the turn of the twentieth century, we begin to see these relations shifting, and many Nahda formations realigning away from the classes and interests that had hitherto formed them. Marrāsh can be seen as a genuine forerunner in that he anticipated these developments, which led on to the situation described by Ilham Khuri-Makdisi at the turn of the twentieth century, of a substantial 'radical' movement, drawing on and in direct continuity with much of the earlier Nahda, but now aligned against the established bourgeois and bureaucratic classes which had contributed to that movement's emergence. ${ }^{12}$

Evidently this study does not pretend to be a comprehensive account of the Nahda in the middle decades of the nineteenth century. It is essentially limited to three formations centred on Beirut, Cairo, and Aleppo - and concentrates within these on the work of a few individuals: Buțrus al-Bustānī, Khalīl al-Khūrī, Rifā'a al-Ṭahțāwī and Fransīs Marrāsh. There are obvious gaps in its coverage: the Arabic press in Europe, Malta, and Istanbul; the work of Aḥmad Fāris al-Shidyāq; the Tunisia of Khayr al-Din and the 1861 Constitution.

12 The Eastern Mediterranean and the Making of Global Radicalism, 1860-1914 (Berkeley and Los Angeles: University of California Press, 2010). 
Only very cursory attention has been given, moreover, to developments before and after the period from the 1830 s to the mid-1870s, though they constitute important parts of the Nahda movement taken as a whole, from the 'Christian Nahda' of the seventeenth and eighteenth centuries to the turn of the twentieth century, the age of the Muwaylihịs, al-Manfalūṭi, and Faraḥ Anțūn. ${ }^{13}$

Within these limits, however, this study aims to bring together the two aspects I referred to above: the social imaginings that formed an integral part of the Arab Nahda, and the conditions in which they arose. I aim to show how the conscious movement which was later, retrospectively, defined as the 'Nahda', arose within specific historical circumstances: as the active, creative cultural response of new social groups in the Arab-Ottoman lands, working under specific determining pressures. In Edward Thompson's phrase, I have tried to describe some of the ways in which 'aspiration quarrel[ed] with actuality', ${ }^{14}$ in this particular time and place, among these people. This quarrel I see as a dialectical process of interaction: neither the weightless 'freedom' from material considerations claimed, for culture or art, both by an older idealism and by more recent trends in postmodern scholarship; nor the mechanical 'reflection' of material realities (economic or otherwise) to which culture's role is restricted by both bourgeois and Marxist varieties of economism. ${ }^{15}$ Civilisation', tamaddun, was not only the external evidence of the new realities being created by capitalism and state modernisation; it was also a standard, an aspiration, a project which Nahda writers saw as their own. 'The 'New Age', for them, was not simply an object of passive contemplation, or

13 I have considered some earlier stages of the nahda elsewhere, however: see my 'The First Arabic Translations of Enlightenment Literature: The Damietta Circle of the 1800s and 1810s', Intellectual History Review 24, no. 2 (2015): 209-33; and 'Early Arabic Translations of English Fiction: The Pilgrim's Progress and Robinson Crusoe', Journal of Semitic Studies LX, no. 1 (2015): 177-212. The later period has been rather more thoroughly studied: see, for instance, Hafez, The Genesis of Arabic Narrative Discourse; Samah Selim, The Novel and the Rural Imaginary in Egypt, 1880-1985 (Albany, NY: SUNY Press, 2004); Khuri-Makdisi, The Eastern Mediterranean and the Making of Global Radicalism.

14 'An Open Letter to Leszek Kolakowski', Socialist Register 10 (18 March 1973): 54.

15 For theoretical statements of this position, see, in addition to Williams, Marxism and Literature; E. P. Thompson, 'Caudwell', Socialist Register 14 (1977): 228-76. 
a set of circumstances from which they hoped to derive some secondary benefits, but at once a challenge and an opportunity: a set of processes which they sought to take part in and to shape. 


\section{Chapter 1}

\section{Who Made the Nahda?}

To be seen in the round, and understood in its real bearings, a pattern of ideas must be seen taking shape in the minds of members of a determinate social group in a specific epoch.

\section{G. Kiernan ${ }^{16}$}

Who made the nahda? What social groups were involved in producing and supporting it, and in what relation did they stand to the other groups of the society? These questions have not always been clearly posed in studies of a literary or intellectual history type either in Arabic or in European languages. Many of these, concentrating on the development of literary forms, concepts, or even cultural institutions, leave us with the impression that the people engaged in creating these things were simply intellectuals, working under the influence of contact with 'Europe'. Much of the general work on the social and economic history of the Middle East from the eighteenth to the early twentieth century, meanwhile, does not deal in detail with the intellectual and cultural movement that became known as the Nahda. A work like Roger Owen's The Middle East in the World Economy ${ }^{17}$ is invaluable, but it sets out a framework within which the 'Nahda' may be placed, rather than examining the movement itself.

There are an increasing number of valuable studies which do bridge this gap, and attempt to deal with some part of the cultural and intellectual movement within its social and economic context. But here we encounter problems of a different order. Much of the best work which will enable us to answer the questions posed above is by social historians writing in English:

16 'Review of Raymond Williams, Culture and Society, 1780-1950', New Reasoner, no. 9 (Summer 1959): 78.

17 Roger Owen, The Middle East in the World Economy, 1800-1914 (London: IB Tauris, 1993). 
Bruce Masters, the late Thomas Philipp, Fruma Zachs, Ami Ayalon. But these historians have not offered general synthesising accounts of the period: indeed, one of the closest approaches to such an account recently, by Philipp, begins specifically with a disclaimer: 'I am not offering a theory or a model, at the best, some general overarching trends $[\ldots] .{ }^{18}$ And this is justified in these terms: 'Looking at the state of the art in our own territory of Middle Eastern history, it is obvious that the dearth of facts demonstrates the need to first unearth and collect the information for the detailed events, and narrow developments, rather than to apply any sort of theoretical, model building.' ${ }^{19}$

This caution is understandable; in an area where so much empirical research remains to be done, it may be wise. But the danger of proceeding without an articulated model, even as unproven hypothesis, is that we may end up unconsciously following an unarticulated one. 'Must we dispense with any model? If we do so, we cease to be historians, or we become the slaves of some model scarcely known to ourselves in some inaccessible area of prejudice.' Thus Edward Thompson - in the course, moreover, of an argument against schematic modelbuilding. ${ }^{20}$ And in this particular field of Middle Eastern history, there is perhaps a more specific danger. If we are unable to relate our history to the arguments and models employed in other kinds of history, we may fall victims to one particular 'area of prejudice': not an empiricism but a particularism, which sees Middle Eastern (or Islamic) history as sui generis, incapable of judgement by 'outside' standards or models.

It is in an effort to escape these dangers that I have chosen to disregard Philipp's warning, and begin with an attempt to think through the history of the 'Nahda' and its period, in

18 'Bilād al-Šām in the Modern Period: Integration into the Ottoman Empire and New Relations with Europe', Arabica 51, no. 4 (2004): 401.

19 Ibid., 401-2.

20 'The Peculiarities Of The English', 350. 
relation precisely to historical models of a general, universalising kind. Such an attempt is it hardly needs saying - provisional and tentative. But it is aided by the existence of prior attempts which have been made along the same lines, notably - although with substantial difficulties, as we shall see - by Arab Marxist historians and theorists. Within this rather neglected tradition - itself reliant in some part upon a Soviet tradition of orientalism - the outstanding effort, in terms of originality and theoretical clarity, is that of the Lebanese Communist Mahdī 'Āmil (alternatively Mehdi Amel; pseudonym of Hasan Ḥamdān) in Theoretical Prolegomena to the Study of the Influence of Socialist Thought on the National Liberation Movement. ${ }^{21}$ As its title proclaims, this was not a work of history as such, but an exercise in the theorisation of history, undertaken in the light of contemporary political preoccupations, and (as it happens) under the dual influence of the dependency theorists and Althusser. ${ }^{22}$ It bears clearly the marks of its origins: strenuously theoretical and often formulaic in the Althusserian manner, light on historical detail, rebarbative and repetitious in style. It continues, nevertheless, to exert a substantial influence over Arab Marxist historiography of the Nahda period: Muhammad Jamāl Bārūt's useful The Arab Enlightenment of the Nineteenth Century: the Aleppo Circle makes considerable use of it (though also of Soviet orientalists such as Vladimir Lutsky and Lev Kotlov), ${ }^{23}$ while Māhir al-Sharīf (Maher Charif) has written a kind of reply to 'Āmil, across thirty years, in his

\section{Issues of the Nahda in Arab Thought. ${ }^{24}$}

21 Muqaddimāt nazariyya li-dirāsat athar al-fikr al-ishtirākī fì harakat al-taharrur al-wațañ̄ (Theoretical Prolegomena to the Study of the Influence of Socialist Thought on the National Liberation Movement). I refer principally to vol. 2: Namaṭ al-intāj al-kūlūnyāli (The Colonial Mode of Production). (Beirut: Dār alFārābī, 1978).

22 In all of these points besides the influence of dependency theory, it bears a considerable resemblance to the work of Perry Anderson with which Thompson was arguing in 'The Peculiarities Of The English'. It seems that a similar attempt at a theoretical understanding of modern Arab history was made at almost the same time as 'Āmil's, by the Palestinian Trotskyist Jabra Nicola, but remains unpublished: see Ran Greenstein, 'A Palestinian Revolutionary: Jabra Nicola and the Radical Left', Jerusalem Quarterly 46 (2009): 44-5 and n. 41.

23 Harakat al-Tanwīr al- 'Arabì fì al-Qarn al-Tāsi' 'ashar: halaqat Halab Numūdhajan (The Arab Enlightenment Movement in the Nineteenth Century: The Aleppo Circle as Model) (Damascus: Ministry of Culture (Syria), 1994).

24 Māhir al-Sharīf, Rihānāt al-Nahḍa fì al-Fikr al- 'Arabī (The Stakes of the Nahda in Arab Thought) (Damascus: Dār al-Madā, 2000). 
More importantly than this influence, and despite its flaws, though, 'Āmil's work attempts to offer a totalising account of modern Arab history, and has the characteristic strength of the Marxist tradition: a sense of history as process. It is an attempt to understand, rather than only describe or narrate, the nineteenth-century history of the Arab-Ottoman world. If the work of Philipp and the fact-gatherers remains at too low a level of theoretical abstraction, 'Āmil's highly rigorous model has, to be sure the opposite difficulty. What follows in this chapter is thus in substantial measure an attempt to bring a revised version of this model into contact with the empirical evidence, largely through the medium of the secondary accounts of scholars like Philipp, Masters and Holt. ${ }^{25}$

'Âmil's thesis may be briefly summarised. The Nahda was the product of a specific social class: a 'rising Arab bourgeoisie', but one which differed from the rising bourgeoisies of European countries (such as France). Its emergence and subsequent development were bound up with the penetration of European capital into the Arab countries - it was a 'colonial bourgeoisie' within a specifically 'colonial mode of production', fundamentally dependent upon colonialism. ${ }^{26}$ 'Āmil suggests that either 'feudalism' or 'oriental despotism' (or both) dominated the Arab-Ottoman world before the advent of European imperialism. There may have been 'harbingers' or 'nuclei' of autochthonous capitalist development, in Lebanon and Egypt, but these were soon overtaken by the capitalism imported from outside. ${ }^{27}$ The nature of the colonial bourgeoisie determined its intellectual evolution and its relation to that of the European bourgeoisie. Hence the Nahda's engagement with modern European ideas, as others such as Ra'if Khūrī had suggested, was due to the 'correspondence' between the rising

25 For a justification of this kind of enterprise, see Thompson, 'The Peculiarities Of The English', 337, 34950.

26 This is not exactly the same thing as traditional Marxists had meant by 'comprador bourgeoisie', though close: see V. P. Panov, 'Comprador Bourgeoisie', The Great Soviet Encyclopedia, 79 1970, http://encyclopedia2.thefreedictionary.com/Comprador+Bourgeoisie.

27 Muqaddimāt nazariyya, 2:57, 72-3. 
Arab bourgeoisie and the rising European (or French) bourgeoisie which had originally produced these ideas. ${ }^{28}$

But within this apparent 'correspondence' was a significant difference: the French revolutionary bourgeoisie with its ideas (or 'class ideological practices', the Althusserian phrase which seems with 'Āmil to engulf the whole of intellectual culture) was independent, while the Arab colonial bourgeoisie was dependent on colonialism. Due to this dependency, the Arab bourgeoisie was not revolutionary (like the French), and did not directly confront the pre-capitalist relations of production and ruling classes (whether understood as 'feudal' or 'oriental-despotic'). ${ }^{29}$ Instead, it 'was formed ... by an operation of class adaptation (takayyuf) in which elements of the old ruling class, feudalists or otherwise, were themselves transformed into a particular kind of bourgeoisie, i.e. a colonial kind' ${ }^{30}$ This led to the perpetuation of 'political feudalism' (apparently another way of referring to what Hourani elsewhere calls the 'politics of notables'). ${ }^{31}$ This bourgeoisie was dependent on reproducing the colonial conditions which had led to its own emergence, by fulfilling the requirements of the 'core' economies for raw materials.

Hence the colonial bourgeoisie in Egypt was formed as an agricultural bourgeoisie, and outside Egypt as an agricultural and commercial bourgeoisie, or more precisely as agricultural landowners whose agriculture was directly linked to the imperial market and its needs, and as import and export merchants; they did not begin to invest their capital in industry until a very late stage of their class development, and in determinate (muhaddad) conditions of dependent cooperation with the imperial bourgeoisie $[\ldots] .{ }^{32}$

These facts explain the Arab bourgeoisie's lack of 'revolutionary' or Jacobin vigour against the old order, and its failure to become a 'national' force against colonialism. Towards the end of the nineteenth century there then emerged a new 'middle class', located between the

28 Ibid., 2:29.

29 Ibid., 2:40.

30 Ibid., 2:74-5.

31 Ibid., 2:54.

32 Ibid., 2:75. 
dominant colonial bourgeoisie and the new working class. Though equally incapable of heading a movement of national liberation, this 'petite bourgeoisie' was subject to the 'class illusion' that it could become the ruling class and set the Arab countries on a path of capitalist development independent of European domination. This explains the 'utopian socialism' of the generation of Shiblī Shumayyil and Farah Anțūn. But dependency on the West, 'Āmil argues, can only be transcended by transcending capitalism as such, and the only force which can accomplish this is the working class: only this class can lead a true national liberation movement. This conclusion, we may note, was of obvious political usefulness to those Arab socialists of the early 1970s who, like 'Āmil, sought to establish a socialist hegemony over the Arab national liberation movements.

This thesis, even in its original, somewhat rigid theoretical terms, is extremely suggestive. It bears a family resemblance to propositions advanced about the Ottoman Empire in general (though usually bearing mostly on its European and Anatolian rather than Arab provinces) by historians influenced by another, Wallersteinian, offshoot of 'dependency theory' ${ }^{33}$ It may also be related to similar arguments made, for instance, of comparable bourgeois or intellectual formations in colonial India, and their limitations. ${ }^{34}$ We may extract from 'Āmil's propositions three main heads of discussion. First, there is the attribution of the Nahda to a specific social class or classes - for 'Āmil, the rising Arab bourgeoisie, with the subsidiary question of when and how this bourgeoisie emerged. Second, there is its relationship with the older ruling classes or orders (for 'Āmil, 'feudalists' or 'oriental despotism'), and for that matter with other groups in the society. Third, there is the matter of its 'dependence' on the West in the context of 'colonial penetration', and the suggestion that it constituted a 'colonial

33 Immanuel Wallerstein, Hale Decdeli, and Resat Kasaba, 'The Incorporation of the Ottoman Empire in the World-Economy', in The Ottoman Empire and the World-Economy, ed. Huri Islamogu-Inan (Cambridge: Cambridge University Press, 1987), 88-97.

34 See Sumit Sarkar, 'The Complexities of Young Bengal', Nineteenth Century Studies (Calcutta) 4 (1973): 504-34; Sarkar, Writing Social History. See below, Chapter 3, for further discussion. 
bourgeoisie'. As a coda, there is the complex question of what exactly was happening around the turn of the century, with the emergence of a new 'middle class' or 'petite bourgeoisie', with its 'radicalism' and 'utopian socialism'. I will deal with each head of argument in turn. But first I must make a crucial clarification. 'Āmil's understanding of history is clearly dependent upon the concept of class - but can we even apply this concept to the nineteenthcentury Arab-Ottoman world, and if so, how?

\section{'Class' and 'mode of production' in the Arab-Ottoman world}

It may help, first, to return to some earlier uses of 'class' and 'bourgeoisie'. As Maurice Godelier has noted, Karl Marx employed the term 'class' in two different ways in his writings: firstly in 'a limited sense designating the social groups that compose modern capitalist society'. This sense refers exclusively to these groups' position in the capitalist production process, and the relations between 'classes' in this strict sense are hence ultimately economic ones. Secondly, however, Marx used 'class' in a much broader sense, including 'the orders and castes of precapitalist societies as well as the classes of capitalist society. ${ }^{35}$ It is in this second sense, for instance, that the Communist Manifesto states that 'The history of all hitherto existing society is the history of class struggles', and refers to 'Freeman and slave, patrician and plebeian, lord and serf, guild-master and journeyman' as all 'contending classes'. But in the stricter sense of 'class', such precapitalist groups were not 'classes' but 'orders' or the like, being based on non-economic forms of domination and exploitation. Only the contending groups of capitalist society, based on economic forms of

35 L'Idéel et le matériel: Pensée, économies, sociétés (Paris: Fayard, 1984), Appendix; see also idem, 'Ordres, Classes, Etat Chez Marx', in Visions Sur Le Développement Des Etats Européens. Théories et Historiographies de l'État Moderne. Actes Du Colloque de Rome (18-31 Mars 1990) (Rome: Ecole Française de Rome, 1993), 117-35. 
domination and exploitation, were classes in this narrower sense. The term 'bourgeois' is subject to a similar ambiguity: it can be used both of the ruling class of capitalist society, and of town-dwelling or merchant groups (not generally the rulers) of precapitalist societies (typically feudal Europe). ${ }^{36}$

It seems reasonably clear that if 'class' in the broad sense can be used of precapitalist European societies, it can be used of nineteenth-century Middle Eastern ones. ${ }^{37}$ It is in this broad sense that we may read Hourani's definition of the 'notables' of Damascus as, like the merchant patriciates of precapitalist Europe, 'an ancient bourgeoisie'. We need not, of course, accept the rather schematic handling of 'class' by 'Āmil: we might see it as better, with Edward Thompson, to use class and class struggle as analytical lenses while 'resisting the attribution of identity to a class' ${ }^{38}$ Nor am I suggesting that we can simply read off all that we need to know about a group of people from their 'class position'. But I am suggesting that class, and class conflict, in the broad sense that covers both capitalist and precapitalist societies, are not only applicable but indispensable if we are to understand the Arab-Ottoman world in this period. It is in these broad senses that I will, unless specified, use terms like 'class', 'ruling class' and 'bourgeoisie' in what follows.

The more difficult question is whether, or at what point, we can apply 'class', or 'bourgeoisie', in the stricter sense of groups within capitalist society, to the Arab-Ottoman world. This raises the very difficult question of the mode or modes of production existing within this 'world', and which of them was dominant at any particular time; and the perhaps

36 See, for instance, Raymond Williams, Keywords: A Vocabulary of Culture and Society, Revised edition (London: Fontana, 1983), 'bourgeois'.

37 It is such a broad understanding of 'class' in relation to Iraq that Hanna Batatu defends, cogently, in The Old Social Classes and the Revolutionary Movements of Iraq: A Study of Iraq's Old Landed and Commercial Classes and of Its Communists, Ba 'thists, and Free Officers (Princeton: Princeton University Press, 1978), 5-12.

38 E. P. Thompson, 'Eighteenth-Century English Society: Class Struggle without Class?', Social History 3, no. 2 (1978): 133-65; see also his 'The Peculiarities Of The English'. 
equally difficult one of the extent of the 'world' or 'society' under examination. Are we to see the Ottoman world as initially constituting a distinct 'world-empire' but then being incorporated, at some point between the early seventeenth and the nineteenth century, into the 'capitalist world-economy'? ${ }^{39}$ Are we to see the Ottoman Empire, or its different provinces, through the nineteenth century, as embodying different kinds of 'articulation' between a capitalist mode of production and other (perhaps 'feudal' or 'oriental-despotic') modes of production $?^{40}$ Are we to see the Arab world as constituting over this period a distinct 'colonial mode of production' dependent on European capitalism? ${ }^{41}$

I will not offer solutions to these questions, but I will suggest, rather schematically, some of the criteria by which we may attempt to decide them. In the first place, I think it is helpful to follow Perry Anderson in retaining the concept of 'mode of production' as an analytical tool, but in seeing neither 'feudalism' nor the 'Asiatic mode of production' (or 'Oriental despotism') as good descriptions of the dominant mode of production in precapitalist Western Asia or North Africa; we may agree that whatever this mode was remains to be effectively described and analysed. ${ }^{42}$ We may then note Eric Wolf's proposal of a broad group of 'tributary' modes of production; ${ }^{43}$ and suggest that (while itself too vague a category for specific historical use ${ }^{44}$ ) this does help mark off a group which might include European and Japanese 'feudalism', plus the as-yet-undefined dominant modes of production of pre-capitalist Western Asia, North Africa, and India, from, on the one hand, modern capitalism, and, on the other, kin-based modes of production.

39 Wallerstein's argument: 'The Ottoman Empire and the Capitalist World-Economy'. For an account of further developments of this idea, in relation to the Ottoman Empire, see Suraiya Faroqhi, Approaching Ottoman History: An Introduction to the Sources (Cambridge: Cambridge University Press, 1999), 188-93.

40 For a critical account of the confusions around this notion, see Aidan Foster-Carter, 'The Modes of Production Controversy', New Left Review 107 (1978): 47-78.

41 'Āmil's argument, in Muqaddimāt nazariyya; cf. Samir Amin's 'peripheral capitalism' formulation, in Unequal Development.

42 Lineages of the Absolutist State (London: New Left Books, 1974), esp. Conclusions and Note B.

43 Europe and the People without History (Berkeley: University of California Press, 1982).

44 As suggested by Eric Hobsbawm, On History (London: Hachette UK, 2011), Ch. 12. 
Having drawn this distinction, we are then faced with the problem of defining capitalism, or what separates it from other (tributary or kin-based) modes of production. Here we must refer to the controversy that began (as the 'transition from feudalism to capitalism' debate) with Paul Sweezy and Maurice Dobb, and continues between 'world-market' Marxists (such as Wallerstein) and 'political Marxists' (such as Robert Brenner and Ellen Meiksins Wood). ${ }^{45}$ If we accept the 'world-market' definition of capitalism, incorporation into the capitalist world-market (or world-system) is sufficient for a given society to be considered capitalist. But for the 'political Marxists', capitalism only exists when the direct producers (workers, peasants, etc) become dependent on the market and have to produce competitively for it. Capitalism is thus defined with regard to the relations of production, rather than to the relations of trade and exchange.

On this view, markets and complex trade systems could and did exist under non-capitalist modes of production: 'urban patriciates or merchant elites in commercial centres in medieval and early modern Europe often extracted great wealth from commercial activities, but they relied in large part on the privileges and powers associated with their status in the city. The success of these commercial centres was dependent less on competitive production than on "extra-economic" factors such as military superiority, command of trade routes, monopoly privileges $[\ldots . .]^{96}$ But 'the market became capitalist when it became compulsory', ${ }^{47}$ at this point, the direct producers had to sell their labour power, by economic mechanisms, under conditions of capitalist 'free labour'. To define a society as capitalist we therefore need to

45 See Paul M. Sweezy and Maurice Dobb, The Transition from Feudalism to Capitalism, ed. Rodney Hilton, Foundations of History Library (London: New Left Books, 1976); and for the later debate, e.g. Robert Brenner, 'The Origins of Capitalist Development: A Critique of Neo-Smithian Marxism', New Left Review 104 (1977): 25-92; Ellen Meiksins Wood, 'The Question of Market Dependence', Journal of Agrarian Change 2, no. 1 (2002): 50-87.

46 Wood, 'The Question of Market Dependence', 285.

47 Ellen Meiksins Wood, 'The Non-History of Capitalism', Historical Materialism 1, no. 1 (1997): 6. 
look for capitalist relations of production, rather than simply for a well-developed market sector: this may exist, but if the dominant productive relations are non-economic ones (e.g. feudal dues, taxation and tax-farming, corvée labour), then this is only a subordinate market sector within a society dominated by a non-capitalist mode of production.

But here - to take a point from the other side of the debate - we must define the extent of this 'society'. For it seems plausible to accept (as Perry Anderson does) ${ }^{48}$ that a given territory or 'society' can contain more than one mode of production, though there will generally be a dominant one. Thus a society dominated by a 'tributary' mode of production (e.g. feudalism) may contain also a secondary, capitalist mode of production (and/or others, 'kin-based' for instance): this may be one way of describing the vigorous but subordinate market sector of premodern Europe alluded to by Wood. If our unit of analysis is a clearly bounded 'society' - European or Arab-Ottoman - we will then require the clear domination of capitalist relations of production over this unit, in order to define it as a 'capitalist society'. But if, past a certain point, we see Arab-Ottoman 'society' as having itself been incorporated into a larger 'world-system', which is as a whole dominated by capitalist relations of production, then we may state that this Arab-Ottoman 'society' is dominated by capitalism (although it may be internally dominated by a different mode of production). The position of its own, internal 'market' or 'capitalist' sector (and of the classes associated with it) would also presumably be modified by this incorporation: although locally still secondary, this sector would now be part of the generally dominant mode of production. From this it appears that we need to locate the point of 'incorporation' referred to by Wallerstein, when the Ottoman Empire - or rather, for our purposes, the Arab-Ottoman world, or specifically Bilād al-Shām and Egypt - became incorporated into the capitalist world-system.

48 Lineages of the Absolutist State, 495. 


\section{A. The Groups that Made the Nahda}

Having presented this brief 'theoretical prolegomenon', we may address the first of our heads: the question of whether we can attribute the cultural movement we call the 'Nahda' to a specific social class or set of classes. It may seem self-evident that it was the product of some specific social groups, but the question is rarely posed in the dominant Arabic-language tradition of intellectual history, and in much older work in other languages. It was on this point, among others, that Māhir al-Sharīf (oddly as it may seem for a Marxist) challenged Mahdī 'Āmil's account, arguing that 'intellectuals' from a wide variety of social origins created the Nahda, rather than a specific class, bourgeois or otherwise. ${ }^{49}$ Muhammad Jamāl Bārūt settles for a compound, the 'new social groups', comprising bureaucrats and intellectuals as well as bourgeois, while seeing, in Aleppo at least, an 'organic' relationship between the intellectuals he studies and the Christian commercial bourgeoisie. ${ }^{50}$

When we turn to other histories, both terminologies and conceptualisations of the various social groups and their roles are widely various. Fruma Zachs, in The Making of a Syrian Identity, offers us a Beiruti 'middle stratum, composed mainly of Christian Arabs', while noting that many before her - Leila Fawaz, Irena Smilanskaya, Fatma M. Göçek, Dominique Chevallier - had called this middle stratum a 'bourgeoisie', a term Zachs herself adopts elsewhere. ${ }^{51}$ It is a term also used - but without extended definition - by Jens Hanssen and Elisabeth Holt. ${ }^{52}$ Another popular term to define urban elites - but generally the 'traditional' rather than the 'modern' ones - had been 'notables' (for the Arabic a 'yān and other terms).

49 Sharīf, Rihānāt al-Nahḍa.

50 Bārūt, Harakat al-Tanwìr al- 'Arabì.

51 In 'Cultural and Conceptual Contributions of Beiruti Merchants to the Nahda', Journal of the Economic and Social History of the Orient 55, no. 1 (2012): 153-82.

52 Jens Hanssen, Fin de Siècle Beirut: The Making of an Ottoman Provincial Capital (Oxford and New York: Oxford University Press, 2005), sometimes as 'intermediate bourgeoisie'; Elizabeth M. Holt, 'Narrative and the Reading Public in 1870s Beirut', Journal of Arabic Literature 40, no. 1 (2009): 37-70. 
There has been a debate over how to define the 'notables' of Syrian cities: order, elite, or class,$^{53}$ with one scholar arguing for a blurring of the distinction between the supposedly modern 'bourgeoisie' of Beirut and the supposedly traditional 'notables' of Damascus or Aleppo. ${ }^{54}$ In his classic essay on 'the politics of notables', meanwhile, Hourani had defined the notability of Damascus as, precisely, 'an ancient bourgeoisie'. ${ }^{55}$ The catch-all 'elite' is widely used of Egypt, as well as more specific definitions like the 'technicians' or 'efendis'. ${ }^{56}$

I therefore propose to begin with a survey of the social groups engaged in the Nahda. By this I do not mean only the cultural 'producers' - writers, intellectuals, and so on - but also those who 'consumed' the cultural and literary products and who were otherwise engaged in supporting or aiding the movement. I propose to identify these groups, initially, in relation to the material of the Nahda movement itself. For we do have evidence - though partial and imperfect - of the kind of people who might have been expected to produce or engage with cultural production of this kind.

\section{The Beiruti bourgeoisie}

There is first the preliminary question of geographical 'spread'. If we go by printed material and the press, it seems probable that for the 'long 1860s', the main focus of this study, the principal centre in the Arab world was Beirut. There had been, as we shall see, earlier,

53 Ruth Roded, 'The Syrian Urban Notables: Elite, Estates, Class?', Asian and African Studies 20 (1986): 375-84.

54 M. James Quilty, 'Bridging the Dichotomy: Socio-Economic Change and Class Consolidation in Ottoman Beirut and Damascus' (Doctoral thesis, Simon Fraser University, 1992).

55 Albert Hourani, 'Ottoman Reform and the Politics of Notables', in The Emergence of the Modern Middle East (Berkeley and Los Angeles: University of California Press, 1981), 36-66.

56 F. Robert Hunter, 'Egypt's High Officials in Transition from a Turkish to a Modern Administrative Elite, 1849-1879', Middle Eastern Studies 19, no. 3 (July 1983): 277-300; James Heyworth-Dunne, 'Printing and Translations under Muhammad 'Alī of Egypt: The Foundation of Modern Arabic', Journal of the Royal Asiatic Society of Great Britain and Ireland, no. 3 (1940): 325-49. 
smaller centres in Bilād al-Shām and Egypt, with Cairo probably dominant in the heyday of the 'translation movement' under Mehmed Ali, in the 30s and 40s, but these were overtaken by Beirut in the 50s and 60s. Egypt probably became again the principal centre - partly through an influx of Syrian literati - from the mid- to late $70 \mathrm{~s} .{ }^{57}$ Other institutions - learned societies, Mārūn al-Naqqāsh's theatre - also suggest that 'Nahda' activity was nowhere more vigorous, in the $50 \mathrm{~s}$ and $60 \mathrm{~s}$, than in Beirut. ${ }^{58}$

Fruma Zachs's Syrian Identity presents convincing evidence for the Beiruti Nahda as the product of a 'middle stratum' consisting largely of merchants and intellectuals. Zachs analyses the membership specifically of two central institutions of the Beiruti Nahda, the Syrian Society for the Acquisition of Sciences and Arts (al-Jam 'iyya al-Sūriyya li-iktisāb al'ulūm wa-l-funūn, 1847-52) and the Syrian Scientific Society (al-Jam iyya al- ilmiyya alSüriyya, 1858-60 and 1868-69). She divides the middle stratum into 'two sub-strata: uppermiddle and lower-middle. The first... was comprised primarily of the city's merchants.' 'The second sub-stratum - the lower-middle, can be described as a "petite-bourgeoisie," and contained intelligentsia, writers and members of the liberal professions.' However, 'the borders between these two sub-strata were quite indistinct. Members of the middle stratum could easily belong to both sub-strata. In some cases, members of the same family belonged to the intelligentsia, while others to the entrepreneurial and merchant sub-stratum. ${ }^{59}$ As

Zachs has shown elsewhere, Beiruti merchants were active not just as patrons or 'consumers'

57 See Ami Ayalon, The Press in the Arab Middle East: A History (New York and Oxford: Oxford University Press, 1995); compare the numbers of periodicals in different centres at different times, in Adam Mestyan, ed., 'Project Jara'id: A Chronology of Nineteenth Century Periodicals in Arabic (1800-1900)', 2012ongoing, http://www.zmo.de/jaraid/HTML/index.html; and for bookshops, Ami Ayalon, 'Arab Booksellers and Bookshops in the Age of Printing, 1850-1914', British Journal of Middle Eastern Studies 37, no. 1 (2010); the surge of production in Beirut in the mid-century appears clearly from Joumana Boustany, 'La Production Des Imprimés Non Périodiques Au Liban de 1733 à 1920 : étude Bibliométrique' (Doctoral thesis, Université Michel de Montaigne, Bordeaux 3, 1997).

58 Zaydān, Tārīkh Ādāb al-Lugha al- 'Arabiyya.

59 Fruma Zachs, The Making of a Syrian Identity: Intellectuals and Merchants in Nineteenth Century Beirut (Leiden: Brill, 2005), 53. 
but as producers of the Nahda, as writers and intellectuals themselves. ${ }^{60}$ Large parts of both 'sub-strata' had been formed, crucially, in towns in Mount Lebanon like Dayr al-Qamar and Zahle, under the reign of Bashir Shihab II, while others had come from elsewhere in Bilād al-Shām. Behind this we can trace a longer history of the rise of what Thomas Philipp called a 'new Arabic-speaking middle class' from the Christian artisanate of Aleppo and Damascus, from the early eighteenth century. ${ }^{61}$ They spread to the coastal towns, then out across the Mediterranean as a 'trading diaspora'; ${ }^{62}$ their history takes in the powerful and cultivated chancellors to local rulers, like the Șabbāghs or the Bahrīs, the Damietta Circle, ${ }^{63}$ the new church institutions, and trade and church connections with Europe.${ }^{64}$ Beirut may have been a new town, but they were a class with a history.

Jens Hanssen's Fin de Siècle Beirut reinforces Zachs's arguments, concentrating on the members of Beirut's municipal council, formed in 1868: 'The majority of the members were merchants, entrepreneurs, bankers, or real estate owners '; ${ }^{65}$ these included two European businessmen. ${ }^{66}$ In addition, 'A small but significant number $[\ldots]$ were $[\ldots]$ career bureaucrats in the Ottoman administration. These bureaucrats did not necessarily depend financially on the Ottoman administration-Ottoman salaries were a fraction of what a successful merchant would earn. Nevertheless, working for the Ottoman state endowed individuals with social status, participatory and transformative urban power. ${ }^{97}$ But 'notables' of a more traditional kind were absent from the council: the 'Druze and Maronite muqāta 'jīs—or rural land- lords

60 Zachs, 'Cultural and Conceptual Contributions'.

61 Thomas Philipp, The Syrians in Egypt, 1725-1975 (Stuttgart: Franz Steiner, 1985), 16-19.

62 Bruce Masters, 'Trading Diasporas and "Nations": The Genesis of National Identities in Ottoman Aleppo', The International History Review 9, no. 3 (1987): 345-6; Philipp, The Syrians in Egypt, 1725-1975, 25-34; the seminal work on trading diasporas is Philip D. Curtin, Cross-Cultural Trade in World History (Cambridge: Cambridge University Press, 1984).

63 Hill, 'The First Arabic Translations of Enlightenment Literature'.

64 Bernard Heyberger, Les Chrétiens Du Proche-Orient Au Temps de La Réforme Catholique, Syrie, Liban, Palestine, XVIIe-XVIIIe Siècles (Rome: École française de Rome, 1994).

65 Fin de Siècle Beirut, 157.

66 Ibid., 138.

67 Ibid., 158. 
—who had dominated Beirut from the surrounding mountain districts of Kisrawan, Matn, and Gharb al-Shuf since the seventeenth century'; 'the urban Sunni group of 'ulama '” (muftīs, faqīhs, and naqībs al-ashrāf)'; and 'Christian religious dignitaries_ patriarchs, priests, and clergymen' ${ }^{68}$ There was, however, considerable overlap with the membership of the Syrian Society analysed by Zachs, and with well-known journalists and writers. Hanssen adds in a footnote: 'In 19th-century Beirut, journalism was rarely a means of subsistence. Most journalists had other means of income, either through family endowments (Qabbānī), or involvement in fathers', brothers', or cousins' businesses (the Țāds or Thābits, for example). ${ }^{69}$ Like Zachs's work on the role of merchants in cultural production, this suggests that the intellectual and merchant 'sub-strata' overlapped, or were at least tightly connected.

For Beirut, then, we have a secure, prosperous class of 'bourgeois': merchants, bankers, property-owners, merging into a slightly humbler group of professionals and 'intellectuals'. ${ }^{70}$ Zachs notes that these families 'were careful to marry among themselves'. ${ }^{71}$ Zachs's or Hanssen's descriptions tally well with that of Butrus Bustānī, in 1869 (to which we will return): 'most of the people of Beirut are lovers of public peace and ease, and have common interests. They are made up of owners of industries, merchants, property-owners and leading persons $[\ldots] .{ }^{72}$ This prosperous bourgeoisie's greatest source of income was the growing silk industry, where the mainly Christian Beiruti merchants 'acted as successful middlemen between the Lebanese cocoon producers and the Western fabric traders, who were for the most part French.' 'Only a tiny fraction' of the money brought into Lebanese hands from the

68 Ibid., 145, 148-9.

69 Ibid., 159n.

70 Elizabeth Holt also speaks in terms of an 'emergent bourgeois reading public', though she concentrates more on the 1870s than the 1860s: 'Narrative and the Reading Public in 1870s Beirut'; 'Serialization and Silk: The Emergence of a Narrative Reading Public of Arabic in Beirut, 1870-1884' (Doctoral thesis, Columbia University, 2010).

71 Making of a Syrian Identity, 55.

72 Khițāb fì al-Hay'a al-Ijtimā 'iyya, in Jān Dāyah, al-Mu 'allim Butrus al-Bustānī : Dirāsa wa-Wathā iq (Beirut: Dār al-Fikr, 1981), 167. 
silk trade 'reached the hands of the farmers and cocoon producers themselves, or the workers who actually spun the silk. Most of the money remained in the hands of the Beirut and Tripoli merchants...' This system 'harmed not only the farmers, but also the traditional muqata'jis.' The rise of the merchant-middlemen therefore appears to have been dependent on the decline of the muqatajis (muqāța $j \bar{j}$-s) - so notably absent from the Beirut municipal council - as well as the exploitation, along new capitalist lines, of farmers and silk workers. ${ }^{73}$ Though the silk produced in Lebanon was almost all exported to France, Beiruti bourgeois seem to have made a good thing out of it as well as the European capitalists. In 1867, 55 out of 67 silk factories in Lebanon were locally owned. ${ }^{74}$

But the Beiruti bourgeois' interests were diverse: for one of the richest, the Sursuqs, Zachs notes that they included 'shipping, silk, and wheat transport to London and to Cyprus', plus banking and investment in infrastructure ('the Suez Canal, the Beirut-Damascus highway, and the Beirut Harbour Company'). Towards the end of the century they became major landowners. ${ }^{75}$ Hanssen notes that the families of Beirut town council members were, as might be expected, major landowners within Beirut, and beginning to invest in land outside the city.

It appears that the boundaries between different modes of wealth accumulation were too blurred to be significant in the politics of Beirut's municipal council, particularly since land could be bought freely on the market after the application of the [new Ottoman] Land Law to Beirut [in 1861]. More significant was the tendency amongst municipal members to cultivate the new quarters by founding schools, hospitals, mosques, churches, printing houses, and

73 Zachs, Making of a Syrian Identity, 55; Kais Firro, 'Silk and Agrarian Changes in Lebanon, 1860-1914', International Journal of Middle East Studies 22, no. 2 (1990): 151, 163-4.

74 Hanssen, Fin de Siècle Beirut, 39n; Firro, 'Silk and Agrarian Changes in Lebanon', 164.

75 Making of a Syrian Identity, 55. 
benevolent organizations. ${ }^{76}$

This, along with the exclusion of older 'notable' groups like the muqatajis and religious leaders from the council, suggests that in Beirut there was a capitalist land market and a bourgeois-municipal relationship to the city, rather than a 'feudal' or precapitalist one. This was a prosperous bourgeoisie, principally it seems commercial and financial, but moving into landholding and industry silk, and with major overlaps with the intelligentsia and officialdom.

\section{Bilād al-Shām: bourgeois and notables}

In the other cities of Bilād al-Shām, this picture is slightly modified. Here a mainly Christian 'bourgeoisie', trading with Europe, was less dominant than in Beirut: local politics was controlled far more by the older-established Muslim 'notables' - 'ulama', tax-farmers, 'ancient bourgeois' ${ }^{77}$ These groups were often still dependent on 'extra-economic' forms of exploitation rather than production for the market; though many of them were also landlords producing for export, the intensive capitalist cash-crop production of Mount Lebanon was less common here than a form of agriculture that tended to preserve traditional landlordpeasant relations. ${ }^{78}$ As well as commercial farming, many of these families were also becoming involved with the expanded Ottoman bureaucracy.

These 'notable' or 'landowning-bureaucratic' elites also lent some support to the cultural movement, though not, it seems, to the same extent as the mainly Christian merchant and

76 Fin de Siècle Beirut, 159.

77 Hourani, 'Ottoman Reform and the Politics of Notables'.

78 Firro, 'Silk and Agrarian Changes in Lebanon', 160. 
professional groups. For the cities of modern Syria and Palestine we have two of the few studies of the Nahda public with any attempt at quantification: Ami Ayalon's surveys of local agents of journals, and subscribers to Bustānī's Dā 'irat al-Ma 'ārif, in Syria and Palestine. ${ }^{79}$ The first set of evidence shows the availability of newspapers extending beyond the major cities to some smaller towns: Hadīqat al-Akhbār, based in Beirut, had had agents in Damascus and Aleppo from the start, and in the 1860s was apparently available in Gaza and Nablus as well as Jerusalem. Al-Jawa 'ib began in 1861 with a representative in Tripoli, and soon had them too in Damascus, Aleppo and Latakia, as well as Jaffa by the late 1860s. The Bustānīs' al-Jinan and al-Janna, from 1870, had agents 'in most of the Syrian towns'; many acquired representatives in Jaffa, Jerusalem, Haifa and Acre in the early $1870 \mathrm{~s} .{ }^{80}$

Specific 'consumers' appear in the lists of subscribers to the first volume of Bustān̄̄s Dáa'irat al-Ma'ārif. There are difficulties with this evidence, as Ayalon points out: it was an expensive, prestigious project, which may have attracted subscribers for reasons of status more than interest, and would presumably exclude many humbler people who took part in other 'Nahda' activities. ${ }^{81}$ It records only intention to subscribe, and dates from the very end of our period: 1874-84, with 80 percent of the names from 1874-5. 'The great majority' of the 1,022 subscribers 'were from Lebanon and Egypt,' plus others from the rest of Bilād alShām and Iraq. ${ }^{82}$

For Ayalon's somewhat arbitrarily-defined 'Syria' (Aleppo, Damascus, Tripoli and Latakia), the lists give, out of a total of 179, thirty-one officials, 'from the wali and mayor of

79 'The Syrian Educated Elite and the Literary Nahda', in Ottoman Reform and Muslim Regeneration (I.B.Tauris, 2005), 127-48; 'Modern Texts and Their Readers in Late Ottoman Palestine', Middle Eastern Studies 38, no. 4 (2002). The third set of evidence Ayalon considers, queries sent in by readers of periodicals, date from too late a period to be useful to us.

80 Ayalon, 'Modern Texts and Their Readers', 23-4; 'The Syrian Educated Elite', 130-1.

81 'The Syrian Educated Elite', 133; 'Modern Texts and Their Readers', 26.

82 Ayalon, 'The Syrian Educated Elite', 134. 
Damascus to members of local administrative councils', fourteen 'senior religious

functionaries, such as the Mufti of Damascus and archbishops', and a 'handful of

foreigners'; but a majority (123 persons) of, mainly Christian, 'ordinary Ottoman subjects'.

For modern Palestine, Ayalon offers a similar picture: subscribers were mainly from the larger towns of Jaffa, Acre and Jerusalem (though also other towns such as Nazareth and Haifa), and again mainly Christian. ${ }^{83}$ We can nuance this description a little if we correlate the lists with the prosopographies we have of leading families of Syrian cities at the time. ${ }^{84}$ In Damascus, Tripoli and Latakia, around half of the subscribers, mostly Christians, can be identified as in some way part of the city's 'elite': consular employees, state or religious officials, or members of well-known merchant families (in Aleppo the proportion of identifiable 'elite' is lower, less than a third). ${ }^{85}$ Damascus's status as provincial capital may account in part for the higher number of subscribers registered here (87 as against around 30 for the other towns). Here, uniquely, a fairly large number (13) of prominent Muslim notables are recorded (Jazā'irīs, Sham 'as, etc) though mainly in the later subscription lists for $1879-84$ rather than for $1874-6$ like the majority of subscribers, perhaps indicating a late growth in interest for 'Nahda' projects. ${ }^{86}$ There are also a few 'elite' Jews. ${ }^{87}$ There are some Muslims in the three other cities, though in Aleppo both the Muslim elite (Jābirīs, Mudarrises, etc) and the Jewish consular families (Piciotto, Silvera) are notable by their absence. Of the remainder of the lists, the vast majority, in all four cities, seem to be

83 'Modern Texts and Their Readers', 25, 26.

84 'The Syrian Educated Elite', 142-6.

85 Peter Sluglett, 'Aspects of Economy and Society in the Syrian Provinces: Aleppo in Transition, 18801925', in Modernity and Culture: From the Mediterranean to the Indian Ocean, Leila Fawwaz, Christopher Bayly and Robert Ilbert (New York: Columbia University Press, 2002), 149, 151-2, 157; Philipp, The Syrians in Egypt, 1725-1975, 16 for the Tarrazis, already trading with Venice and Iran in the seventeenth century.

86 For these families, see Linda Schatkowski Schilcher, Families in Politics: Damascene Factions and Estates of the 18th and 19th Centuries (Wiesbaden: F. Steiner, 1985), 73, 167-9, 197-200; Philip S. Khoury, Urban Notables and Arab Nationalism: The Politics of Damascus 1860-1920 (Cambridge: Cambridge University Press, 2003), 31-2, 34-7, 42-4, 113-4.

87 Two Farhīs: see Schilcher, Families in Politics, 63-4; Thomas Philipp, 'The Farhi Family and the Changing Position of the Jews in Syria, 1750-1860', Middle Eastern Studies 20, no. 4 (1984): 37-52; one Sāsūn (see below); plus Salim Levy Islambuli, Deputy-Consul of Denmark, and Ya'qub Islambuli, banker, also appear to be Jews. 
Christians of the humbler but respectable families - professional, clerical, middlingmerchant. Ayalon notes professions such as 'school headmaster, banker, physician, foreign consulate employee', and that all the subscribers were men. ${ }^{88}$

As well as noting, with Ayalon, that 'consumers of cultural products' of the Nahda in the last quarter of the nineteenth century were 'overwhelmingly men $[\ldots]$ with very few exceptions they were townsmen; $[\ldots]$ predominantly Christian' and contained 'multiple members of the same family, ${ }^{89}$ this permits us to give a rough class breakdown. Even for an expensive project like $D \bar{a}$ 'irat al-Ma'ārif, around half of subscribers were from humbler merchant, professional, clerical or 'intelligentsia' families; and most of the 'elite' were Christians rather than the Muslim notables. This appears to replicate the composition of the 'lower' and 'upper' substrata engaged in the 'Nahda' in Beirut - though in the Syrian interior these Christian bourgeois families were far less considerable in society as a whole (rather than 'Nahda' cultural life) than the Muslim notable or landowning-bureaucrat families. It is worth noting that the Christian clergy, including the hierarchy, were by no means absent from this public (and many of the presses continued to be Church-controlled). Many of the families concerned - even beyond the known 'elite' - are likely to have been old-established ones, with roots in the earlier cultural history of towns like Aleppo and Damascus. ${ }^{90}$ Given the frequent connections with foreign consulates and foreign trade, as well as less frequent ones to Ottoman bureaucracy, we can also suggest that a large section of this 'Arabic' reading public was bi- or multilingual.

88 'The Syrian Educated Elite', 134.

89 Ibid., 135-6.

90 See e.g. Otared Haidar, 'Aleppo: The First Ground for Arab-European Cultural Encounters in the Early Modern Period', in From Ancient Arabia to Modern Cairo: Papers from the BRISMES Annual Conference 2009, ed. Philip Sadgrove, Journal of Semitic Studies Supplements 28 (Oxford: Oxford University Press, 2012), 127-38 and Chapter 4, below. 


\section{Egypt: officials, teachers and students}

In Egypt, no such surveys of the public exist, as far as I am aware. The early $a l-W a q a \bar{a} i{ }^{`} a l-$ Mișriyya existed in both Arabic and Ottoman, and was designed initially, according to Ekmeleddin İhsanoğlu, for the Pasha's family and retinue, for officials 'both civilian and military' and for the Azharis; to these groups were later added schoolteachers and students. ${ }^{91}$ The Arabic-only Rawḍt al-Madāris, which Țahțāwī later edited, was intended for the new teachers at Dar al-Ulum. It seems a fair guess that the centre of gravity of the reading public of the Arabic press in Egypt, beyond the schoolteachers themselves, was the growing Arabicspeaking bureaucrat class, trained in the new government schools or, for a few, in Europe. The most well-known writers and educational reformers of the Nahda - Ṭahṭāwì, 'Alī Mubārak - were part of the higher levels of the bureaucracy; but there was a substantial public of lower-ranking officials. Many of them, like Ṭahtāwī, had roots in the old, Azhari or 'traditional' system of education, as well as in the new government schools. It is difficult to draw a clear line between 'traditionalists' and 'modernisers' in the early and mid-nineteenth century: as we shall see, intellectuals like Ṭahțāwi drew on both old and new sources of legitimation. Syrian Christians living in Egypt may have constituted a subsidiary public with similar features to that profiled above for Beirut and Bilād al-Shām. But it was only from the second half of the 1870s that Syrians in Egypt began to outstrip those based in Beirut in their periodical production: al-Ahrām was founded (by Syrians) in 1876; al-Muqtataf moved from Syria to Egypt three years later. ${ }^{92}$

This pattern of close identification of the cultural movement with the state had been initiated with the establishment of the Būlāq Press, which was largely designed to serve the military,

91 Ekmeleddin İhsanoğlu, The Turks in Egypt and Their Cultural Legacy (Cairo: American University in Cairo Press, 2013), 246.

92 Philipp, The Syrians in Egypt, 1725-1975, 97. 
bureaucracy and government schools. There was, on the other hand, an increasing number of books printed at Būlāq at private expense from the 1830s onwards - but they were predominantly in Turkish, and in any case never matched the number of state-sponsored publications. ${ }^{93}$ The Egyptian press was somewhat in abeyance during these years, from the tail-off in publishing at the Būlāq Press in the late 1840s, which was not compensated for, it appears, by the small number of works produced on private presses from this period onwards. ${ }^{94}$ The situation revived somewhat under Ismail, who sponsored the press and theatre: Abū al-Su 'ūd's $W \bar{a} d \bar{l}$ al-Nìl began to appear in 1867, but the major developments did not come until the mid-1870s. ${ }^{95}$

Outside of Bilād al-Shām and Egypt, we can perhaps assume a similar profile for the readership. A rough guide to the level of 'Nahda' activity in different places is provided by the spread of newspapers and periodicals. Thus Tunis had the official al-Rā'id al-Tünisì from 1860, and at least one other paper by 1874. In Istanbul, from 1860, Shidyāq was editing al$J a w \bar{a}$ 'ib (after a couple of attempts by others to establish Arabic papers there in the 1850s). In Iraq, Dawud Pasha may possibly have published an official newspaper in the 1810s; in 1863 a Judeo-Arabic publication was started; and in 1869 the governor Midhat Pasha began the official Ottoman/Arabic paper al-Zawrā'. By the early 1870s there were also Ottoman official papers in Mosul, Aleppo, Damascus, Sana'a, Tripoli of Libya, and Mount Lebanon (Beiteddine/Dayr al-Qamar). Algiers had two French/Arabic papers started in 1839 and 1847 and from 1870 a Judeo-Arabic/French one. In Europe, Paris saw the publication of 'Uțārid in 1858-9, and Birjīs Bārīs from 1859 to 1866 . Through the 1860s and early 1870s Rizqallāh

93 C.-H. Hsu, 'A Survey of Arabic-Character Publications Printed in Egypt during the Period of 1238-1267 (1822-1851)', in History of Printing and Publishing in the Languages and Countries of the Middle East, ed. Philip Sadgrove, Journal of Semitic Studies Supplements 15 (Oxford: Oxford University Press, 2004), 5-6.

94 Ibid., 7-8.

95 Mestyan, 'Project Jara'id'; Philip Sadgrove, The Egyptian Theatre in the Nineteenth Century: 1799-1882 (Reading: Garnet \& Ithaca Press, 1996), Chs. 4 and 5. 
Ḥassūn was publishing various papers from London, of which the most important was Mir'āt al-Aḥwāl. Arabia and Morocco appear not have supported their own publications until much later, though they undoubtedly possessed readers of the Arabic press. We should also note the existence of a substantial Arabic press in India (a large part of it lithographed), ${ }^{96}$ and of a Judeo-Arabic press (among the Baghdadi Jewish community) in Bombay and Calcutta $;{ }^{97}$ while by the late nineteenth century at least, Arabic printing (though perhaps not of 'Nahda' materials) was spreading in Java and Cape Colony. ${ }^{98}$ Many of the new periodicals were bi- or multilingual: some published in French and Arabic; Ottoman official papers were generally in Ottoman Turkish and Arabic (and in Aleppo in Armenian as well). A Cairene commercial journal was published in Italian, colloquial Egyptian and French, a paper at Shiraz in Arabic and Persian. ${ }^{99}$

\section{Patterns of patronage}

So much for the 'consumers' and direct 'producers' of the Nahda. But we also need to examine the mechanisms - involving other groups - by which the literary and cultural movement was supported. Again focussing on literary activities, we can enumerate the different types of support. Firstly there was Church patronage, in the old-established pattern of the 'Christian Nahda'. Protestant missionary patronage may perhaps be seen as sufficiently distinct to constitute a separate category. State or official patronage by the

96 Though the literature on it seems rather thin; see T. W. Clark, 'The Languages of Calcutta, 1760-1840', Bulletin of the School of Oriental and African Studies 18, no. 3 (1956): 453-74.

97 Orit Bashkin, 'Why Did Baghdadi Jews Stop Writing to Their Brethren in Mainz? - Some Comments about the Reading Practices of Iraqi Jews in the Nineteenth Century', in History of Printing and Publishing in the Languages and Countries of the Middle East, ed. Sadgrove,.

98 Michael Laffan, 'The New Turn to Mecca. Snapshots of Arabic Printing and Sufi Networks in Late 19th Century Java', Revue Des Mondes Musulmans et de La Méditerranée, no. 124 (2008): 113-31; Samuel A. Rochlin, 'Early Arabic Printing at the Cape of Good Hope', Bulletin of the School of Oriental and African Studies 7, no. 1 (1933): 49-54.

99 Mestyan, 'Project Jara'id'. 
Ottoman or Khedivial governments was often linked to a specific reforming official (Jibrā' $\overline{1} l$ Dallāl worked specifically for Khayr al-Dīn al-Tūnisī when he was Ottoman Sadr Azam (Grand Vizier); Midhat Pasha personally founded the Baghdadi paper al-Zawrā $\left.{ }^{\prime}\right) .{ }^{100}$ This was perhaps a modification of the old system of personal patronage by a ruler or minister of poets and secretaries. Any periodical, even a 'private' one, had to have state authorisation. ${ }^{101}$ The original Būlāq Press, under Mehmed Ali’s direct supervision and protection, may similarly be seen as a transitional stage, from the personal patronage of a ruler to that of a bureaucratic state. Patronage was also available from foreign sources: missionaries were often linked to foreign interests. Then there was private patronage, by individuals such as Mudawwar or societies like the Jam iyya Sūriyya. Finally, of course, there was commercial market production, which does not seem to have been the major source of support in this period - though it had in fact been present since the eighteenth century: the Lebanese monastery of Shwayr sold its books. ${ }^{102}$ Subscription ventures such as Bustānī’s Dā 'irat alMa 'ārif were, as in Europe, a halfway house between patronage and the market. ${ }^{103}$

Some of these patrons had, of course, conflicting interests. Bustānı̄'s Jinān came into conflict with Ṣābūnjī’s Naḥla (in which instance it was backed by the Ottoman governor and Șābūnjī condemned) and with the Jesuits' al-Majma' al-Fätikānī: in both cases there was an undercurrent of rivalry between Catholics (and French) and Ottomans. ${ }^{104}$ Antonius Ameuney's project for a London-based newspaper (which never materialised) was supposed to be a Protestant and 'thoroughly English' counter to Rushayd al-Daḥdāḥ’s Birjīs Bārīs (as

100 Bārūt, Harakat al-Tanwīr al- 'Arabī, 40; Mestyan, 'Project Jara'id'.

101 For Ottoman permissions for Arabic journals, see Till Grallert, 'To Whom Belong the Streets? Property, Propriety, Appropriation: The Production of Public Space in Late Ottoman Damascus, 1875-1914.' (Doctoral thesis, Freie Universität Berlin, 2014).

102 Heyberger, Les Chrétiens Du Proche-Orient, 441.

103 The Encyclopedia was, apparently, not a pure public-subscription venture, but also subsidized by Ismail of Egypt: Zachs, Making of a Syrian Identity, 61.

104 Bārūt, Harakat al-Tanwīr al- 'Arabī, 42 and n; Yūsuf Q. Khūrī, Rajul sābiq li- 'așrihi: al-mu 'allim Buṭrus al-Bustānī, 1819-1883 (Amman: Bīsān, 1995), 210-13. 
well as to Russian interests). ${ }^{105}$ Rizqallāh Hassūn, from Russia, is supposed to have proposed an Arab state independent of the Ottomans, under the patronage of the Tsar. ${ }^{106}$ Various Arab journalists were enlisted, that is, for the Ottoman, British, French and Russian causes on the Eastern Question.

The unified nature of the Arabic journalistic discourse was evident, however, from the fact that these projects were all aware of and responsive to each other. Like the Orthodox and Catholic polemicists of the eighteenth century, they belonged to a shared world of discourse. Indeed, one wonders sometimes whether publicists such as Ameuney were not largely playing on imperial rivalries in order to get their subsidies, rather than espousing them as their own. Intellectuals and journalists often combined different sources of patronage, or switched between patrons. Hadīqat al-Akhbār was set up with Ottoman official approval and funding from a Christian merchant, Mìkhā'îl Mudawwar (as well as being, according to Ameuney, guaranteed by the Orthodox Bishop of Beirut). ${ }^{107}$ It subsequently received direct subsidies from Fuad Pasha, who used it as a semi-official organ, and from the Khedive Ismail. ${ }^{108}$ Some of its income always came from the reading public itself via retail sales and subscriptions. The first Syrian Society of 1847 had Protestant missionary patronage, but many of the same members founded the Syrian Scientific Society in 1868 at the initiative of Young Ottomans: Fuad Pasha was an honorary member. ${ }^{109}$ Fāris al-Shidyāq moved between Protestant missionary, Tunisian, and Ottoman patronage, with intervals of private commercial production. Ṭahțāwī, best-known for his work for the Egyptian state, published his Télémaque translation in Hadīqat al-Akhbār. Șābūnjī left the Jesuits to work for Wilfred Scawen Blunt. Rizqallāh Ḥassūn was secretary to Fuad Pasha before working for the

105 Antonius Ameuney, Notes from the Life of a Syrian (London: W. Bennett, 1860), 67-8. 106 Bārūt, Harakat al-Tanwīr al- 'Arabī, 37-8.

107 Hadīqat al-Akhbār, no. 1, 1 January 1858; Ameuney, Notes from the Life of a Syrian, 67-8.

108 Zachs, Making of a Syrian Identity, 229.

109 Bārūt, Harakat al-Tanwīr al- 'Arabī, 12-13, 36. 
Russians. ${ }^{110}$ This ability to switch patrons was no doubt an important factor making for a measure of intellectual freedom: writers worked, increasingly, under conditions of capitalist 'free labour'. Many writers were self-patronised, so to speak, being wealthy in their own right or from wealthy families. ${ }^{111}$ But some of the most successful were in fact able to make a living from literary and educational activity, as a new kind of entrepreneur: the Bustānīs, with their family dynasty, their diversified enterprises (school, various newspapers, book projects) were working in the same mode as the Beiruti merchant-entrepreneurs, but in this specifically cultural domain.

The Nahda press in this period was thus not - yet - a fully capitalist enterprise. Writers and intellectuals often had other means of subsistence, as members of the propertied classes themselves. Their projects' principal support came from wealthy bourgeois, officials and governments, and foreigners - but via patronage rather than a market in cultural products. Sales on the 'open market' appear to have accounted for only a small proportion of the income of cultural enterprises. Their projects had to have political as well as financial support: this was not a situation of 'free speech', and the patronage of governors and rulers was crucial.

\section{'Hidden categories' in the Nahda public, and summary}

This then appears to be the principal audience and support base for the 'Nahda' of the long 1860s. Of course, its influence and readership probably spread beyond this, even before the new phase of expansion of the press which Sabry Hafez places in the 1870 s or early 1880 s. ${ }^{112}$ In particular we should note two 'hidden' groups who do not appear in the sources used above: the poor, including some of the illiterate, and women. One major set of evidence - the

110 Ibid., 37-8.

111 See also Zachs, 'Cultural and Conceptual Contributions'.

112 The Genesis of Arabic Narrative Discourse, 83. 
subscribers to $D \bar{a}^{\prime}$ irat al-Ma 'ârif-derives, as noted, from an expensive and prestigious project. The public that would have bought cheaper books would presumably have been wider; the public that read newspapers wider still; and beyond that lies the world of occasional literacy or access to written material through reading aloud in cafes and the like. The likely extent of this reading public is one of the great unanswered questions about the Arabic press in the mid-nineteenth century; ${ }^{113}$ though Ziad Fahmy has recently made an attempt - focussing on a later period - for Egypt. ${ }^{114}$ In any case, for the middle decades of the century, before the 1870 s watershed, it seems that the target audience - the 'ideal readers' of Nahda writers and journalists - were the prosperous, professional and propertied, not the lower-middle-class, the poor, or illiterates, though their concerns may have come through in oblique ways. It was also after this watershed that writers of humble and obscure origins, like 'Abdallāh al-Nadīm and Jurjī Zaydān, rose to prominence, creating what Sabry Hafez calls a 'new sensibility'. ${ }^{115}$

There were also certainly women readers (and presumably auditors) who have left little trace in public records such as subscription lists. Zachs and Halevi suggest that the women readers of Hadīqat al-Akhbār, present from its first year, were a conscious group with their own notion of the honour of their sex. ${ }^{116}$ The Bustānīs also acknowledged the presence of women in their public. ${ }^{117}$ By the start of the 1870 s, women writers were beginning to publish their own works in the Syrian press: the first of them were members of families already engaged in the cultural movement, like Māriyāna Marrāsh. ${ }^{118}$

113 Zachs deals with some of its difficulties in Making of a Syrian Identity, 158-61.

114 Ordinary Egyptians: Creating the Modern Nation through Popular Culture (Stanford: Stanford University Press, 2011).

115 The Genesis of Arabic Narrative Discourse, 15, 117-25.

116 'From Difā' al-Nisā' to Mas'alat al-Nisā' in Greater Syria: Readers and Writers Debate Women and Their Rights, 1858-1900', International Journal of Middle East Studies 41, no. 4 (2009): 617-8.

117 Hill, 'Early Arabic Translations'; Zachs and Halevi, 'Difā' al-Nisā’ to Mas'alat al-Nisā', 620. 118 'Difā' al-Nisā' to Mas'alat al-Nisā', 619-20. 
This then appears to be the geographical and social spread of the Arabic cultural and intellectual movement in our period. It was largely based in urban centres across the Arab world - though also the Ottoman capital Istanbul and European capitals such as London and Paris. It was indeed the work of 'intellectuals', but this is hardly sufficient as a description: it was organically linked to what we may indeed call a 'bourgeoisie', a class of merchants and capitalists whose wealth derived from the market economy; as well as to a new Arabicspeaking bureaucracy, as in Egypt. The cultural movement was most active where these groups were strongest (Beirut, followed by Cairo and Alexandria). Bārūt's 'new social groups', of bourgeois, officials and intellectuals, is perhaps the most convenient way to refer to them collectively - though their ties to 'old' social groups remained strong. The movement was sponsored by other powerful interests: foreign powers and missionaries, and the Ottoman, Egyptian and Tunisian dynasties. It also found supporters and producers among the 'traditional' notable, ulama, clerical, and muqataji elites; and its more 'traditionalist' sections were probably keen to further these links. It was further from the mass of the people, who were mainly illiterate and mainly rural. It is the relation of the "new social groups' to these other groups in the society, and particularly to the old ruling classes, that we must next examine.

\section{B. Class Conflict and 'Adaptation'}

Our third head of argument is: in what relation did these classes who created the Nahda stand to other groups in their societies and outside them? After attempting to define these classes and their history, we must turn to the overall class situation within which they operated. In practice this is inseparable from these various groups' relations to the major changes taking place in these societies through the nineteenth century: incorporation into a world economy 
dominated by the capitalist countries of Western Europe, and the extension of 'modern' state power far beyond the limits to which older forms of government had been confined. 'Āmil thinks of these relations in terms of 'adaptation' (as opposed to bourgeois-revolutionary class struggle); while others such as Fawwāz Ṭarābulsī have seen the very sharp social conflicts of the area as at least partially forms of class struggle. ${ }^{119}$

The two suggestions may be reconciled if we see the emergence of the 'new social groups' Syrian bourgeoisie, the reforming Ottoman bureaucracy, Ottoman-Egyptian elite and dynasty of Mehmed Ali - as falling into two phases. The first was one of violent and often confused struggle against established groups in these societies. In the Ottoman Empire, the Tanzimat reforms began with the suppression of the Janissaries and other contenders for power. ${ }^{120} \mathrm{In}$ Egypt, Mehmed Ali came to power after a struggle against other contenders, culminating in his massacre of the Mamluks. In Bilād al-Shām, we can note Ibrahim's invasion of Syria and revolts against it; then the religious violence of 1850 in Aleppo, and of Damascus and Mount Lebanon in 1858-61, in addition to smaller riots on a similar pattern. The second phase, however, was one of 'adaptation' and accommodation to the older ruling groups: a long period of apparent social stability in which new and old elements coexisted. The whole appears in retrospect as governed by general processes of incorporation into the world economy and of state centralisation. ${ }^{121}$

119 Fawwāz Țarābuls̄i, A History of Modern Lebanon (London: Pluto, 2007); This had also been the standard interpretation of Soviet scholars: e.g. Vladimir B. Lutsky, Modern History of the Arab Countries, trans. Lika Nasser (Moscow: Progress Publishers, 1969).

120 Halil İnalc1k, Studies in Ottoman Social and Economic History, Collected Studies 214 (London: Variorum Reprints, 1985), 50-55.

121 For reasons of space I have left the central Ottoman bureaucracy itself out of this analysis, except as an 'external' factor: but see, for instance, the description of the Ottoman 'ruling class' in Carter V. Findley, Bureaucratic Reform in the Ottoman Empire: The Sublime Porte, 1789-1922 (Princeton: Princeton University Press, 1980). 


\section{Egypt: the Arab 'technicians' in an Ottoman bureaucracy}

In Egypt, Mehmed Ali had come to power by the elimination of other rivals and factions; he was able to assert his 'total' control over the country (and monopolise its economy) only after he had broken the old ruling class, the Mamluks, with the famous massacre of 1811 and the abolition of the iltizams. During his economic 'experiment', though no real political opposition arose in Egypt, there was constant upheaval, peasant flights, and desertion from the army, as well as of course his military campaigns, largely imperial in nature. ${ }^{122}$ After 1840 , however, there followed a period of political stability which lasted under his successors until the late 1870 s, the nationalist agitation and British invasion of 1881-2. During this period Egypt was dominated by the new ruling class, the 'Ottoman-Egyptian elite', which originated largely in Mehmed Ali’s family and entourage.

Politically, Mehmed Ali’s regime was in some ways a modification, though a dramatic one, of the Mamluk ones that had preceded it: the new Pasha's household engrossing and replacing the multiplicity of Mamluk households. Its dynastic aspirations were clearly conceived (as Khaled Fahmy and others have argued) as internal to the Ottoman Empire. ${ }^{123}$ In other ways it might be compared to the mercantilist absolutisms of an earlier era of European history: militarist, aggressively expansionist, eager to seize and monopolise resources. ${ }^{124}$ Its ruling class, in the early period, basically derived its authority from the dynasty and state: a 'service elite' comparable perhaps to the 'service nobilities' of Eastern European empires. ${ }^{125}$ Yet it was undoubtedly part of, and attuned to, the European-dominated

122 For the latter, see Hassan Ahmed Ibrahim, 'The Egyptian Empire, 1805-1885', in The Cambridge History of Egypt, vol. 2: Modern Egypt, From 1517 to the End of the Twentieth Century (Cambridge: Cambridge University Press, 1998), 198-216.

123 See the conclusion to All the Pasha's Men: Mehmed Ali, His Army and the Making of Modern Egypt (Cambridge: Cambridge University Press, 1997); cf. the evidence adduced below, in Chapter 3, and in my 'From Ottoman Despotism to Islamic Constitutionalism' (unpublished manuscript, 2015).

124 See e.g. Anderson, Lineages of the Absolutist State, 32-33.

125 See ibid., 218-220. 
capitalist world market - Mehmed Ali seeking for a time to monopolise trade as well as political authority, and altering Egypt's agriculture to that end, in a way perhaps pioneered earlier by Jazzar Pasha in Acre. ${ }^{126}$ It involved considerable innovation and 'improvement': irrigation works, industry, and above all the introduction of long-staple cotton.

Nonetheless I agree with Kenneth Cuno in seeing Peter Gran's claims of an Egyptian 'capitalism' in the eighteenth or early nineteenth century as incorrect, despite the existence of a substantial market sector. ${ }^{127}$ Although attempts seem to have been made to give the peasants economic incentives, the system was basically dependent on extra-economic coercion: the corvée and its military equivalent, conscription. (These, however, were themselves of new kinds: conscription of Egyptians was a novelty, and peasants recruited for corvée were now liable to be sent outside their own area.) Nor were Mehmed Ali's relations with the European merchants to whom he sold the produce governed by pure 'market' forces, despite their pressure for public auctions rather than private (and occasionally forced) sales. ${ }^{128}$ The ruling class remained, through the first half of the century, a state elite rather than a class based on landholding as such.

What originated as a state-based elite, however, gradually transformed itself in the later nineteenth century into a landowning class, which began to introduce capitalist relations of production into agriculture ${ }^{129}$ - although I am unsure at what points to place the key 'threshold' moments in this process. Besides Albanians, Turks and Circassians, the elite came to contain an increasing number of Egyptian Arabs, drawn from the ulama and urban

126 See Thomas Philipp, Acre: The Rise and Fall of a Palestinian City, 1730-1831 (New York: Columbia University Press, 2001).

127 The Pasha's Peasants: Land, Society, and Economy in Lower Egypt, 1740-1858 (Cambridge: Cambridge University Press, 1992), 3-4.

128 For these points, see Roger Owen, Cotton and the Egyptian Economy, 1820-1914: A Study in Trade and Development (Oxford: Clarendon Press, 1969).

129 This process is treated in Ra' ūf 'Abbās Hāmid and Assem El-Dessouky, The Large Landowning Class and the Peasantry in Egypt, 1837-1952 (Syracuse, NY: Syracuse University Press, 2011). 
merchant-notable groups as well as the rural notables. F. Robert Hunter locates a turning point in the 1850s, when 'For the first time, Egyptians began replacing Turks at high levels in both the provincial and central administrations. ${ }^{130}$ The split between these elements and the 'Ottoman-Egyptians' was later behind the nationalist and Urabist movement. ${ }^{131}$ Through the 1840 s-70s, however, they were a relatively weak component, though growing in strength: politics were confined to 'court politics' ${ }^{132}$ A kind of compromise between remnants of the old ruling class (Mamluks), the dominant ruling class (Ottoman-Egyptians, including the Khedivial family) and an emergent class of Arab Egyptians, was maintained. Peter Gran has suggested for this period Gramsci’s term (borrowed from Vincenzo Cuoco) of 'passive revolution': a period of substantial change but under the domination of a limited group, excluding the mass of the people from any part in politics. ${ }^{133}$ It was also, we should note, a period of peaceful rather than violent politics: the bloodshed of the faction-fights of the 1800 s, as well as the Cairene crowds, were excluded from the political game. Taking the two periods together, we can apply another Gramscian framework: this was a transition from a 'moment of force' to a 'moment of consent'. ${ }^{134}$ The 'moment of consent', the effective settlement between the three classes (and of course the European Powers), provided the context for the expansion of commercial activity (and European penetration), the cotton boom, the beginning of agrarian capitalism.

What was the position, in either period, of the 'technicians', the new Arabic-speaking bureaucrats? In the first place we should remember that the state remained, until well into the 130 ‘Egypt's High Officials', 283.

131 Hunter, 'Egypt's High Officials'; the argument is based on Ibrahim Abu-Lughod, 'The Transformation of the Egyptian Élite: Prelude to the'Urābī Revolt', The Middle East Journal, 1967, 325-44, though Hunter $(288 \mathrm{n}$.) considers that he overstated the case.

132 Hourani, 'Ottoman Reform and the Politics of Notables', 97-8.

133 Peter Gran, "'Passive Revolution" as a Possible Model for Nineteenth-Century Egyptian History', in Money, Land and Trade: An Economic History of the Muslim Mediterranean, ed. Nelly Hanna, The Islamic Mediterranean (London: I.B.Tauris, 2002), 84; Antonio Gramsci, Selections from the Prison Notebooks, trans. G. Nowell-Smith and Q. Hoare (London: Lawrence and Wishart, 1971), 59 and n. 11.

134 Gramsci, Selections from the Prison Notebooks, 169-70; or in another of Gramsci's formulations, 'hegemony' rather than "crude dictatorial "dominance"': 58 n. 8; see also 80 n., 55-60. 
second half of the nineteenth century, an Ottoman-dominated affair. Ehud Toledano and Khaled Fahmy have laid much emphasis on the Ottoman and dynastic (as opposed to Egyptian and national) character of the Egyptian state in the first half of the century. ${ }^{135}$ Fahmy, however, dissents from Toledano's rather Manichaean view of the divide between the 'Ottoman-Egyptian elite' and the rest, laying emphasis on those elements who mediated between the two. ${ }^{136}$ This, moreover, in a study of the army, the most Turkish-dominated part of the Egyptian state. When we examine the civil bureaucracy, we find that Arabic-speaking Egyptians played a still more important role. We should recall firstly that the Būlāq Press designed to serve the government schools and departments - produced only slightly more Turkish than Arabic books, which argues for numerical parity within the educated sections of the administration. Nor were all of the Egyptians in the civil service confined to lowly positions. The intellectuals Ṭahțāwī and 'Ali Mubarak, for instance, were part of the first Egyptian cadres to rise to high position within the bureaucracy. Hunter divides the Egyptians serving in high government positions into two classes: the 'technicians' (Heyworth-Dunne's 'efendis') who had had a European education; and the 'notables', 'village shaykhs with limited education, but who were recruited because of their knowledge of the countryside'. ${ }^{137}$ It was among the former, as might be expected, that the leading intellectuals were to be found. As to their origins, they tended to come from Egypt's existing 'native elites': ulama, merchants, and rural notability. ${ }^{138}$

Hunter anatomises the other groups in high office. Firstly there were, of course, the Turks, 'the most influential and numerically the largest group', who 'continued to direct most

135 Ehud R. Toledano, State and Society in Mid-Nineteenth-Century Egypt (Cambridge: Cambridge University Press, 2003); Fahmy, All the Pasha's Men.

136 All the Pasha's Men, 26-9. As he points out, much of the evidence presented by Toledano can be read in a way that supports other conclusions.

137 Egypt under the Khedives, 1805-1879: From Household Government to Modern Bureaucracy (Cairo: American University in Cairo Press, 1999), 89.

138 Ibid., 85 and Table 11, 89-91. 
government departments' ${ }^{139}$ There were also the Armenians, men like Hekekyan and Nubar Pasha, generally European-educated and well-connected, who tended to dominate in Foreign Affairs and Education; $;{ }^{140}$ and the Europeans, present in most parts of the government and especially in transport and railway-related areas. It was only from the mid-century that Europeans began to be appointed 'as directors and deputy directors of major government departments'. ${ }^{141}$ In addition, there were a few officials who do not fit these categories (like Șiddīq, a fallah's son who rose to great wealth and power), including a handful of Copts. ${ }^{142}$

It was with all these that the Egyptian 'technician' elite, largely identical, through these years, with the intellectual elite of the Egyptian Nahda, shared the government service; nor was it by any means the strongest element. We should note, too, that in the economic transition from monopoly to large landed estates, the 'technicians' did relatively poorly compared to other members of the elite. According to Hunter, the Turkish officials and Egyptian rural notables in government service acquired large amounts of land (and went on to constitute an important part of the landowning class later in the century); whereas the 'technicians' and the Armenian and European officials received much less. The Turks, as well as being in the highest positions overall, were also often in charge of provincial administrations, as were the Egyptian notables, giving these groups more opportunities than others to acquire land. ${ }^{143}$

Still, the position of the 'technicians' by the mid-1860s, say, with seven officials of bey and one of pasha rank, was not simply that of an intermediate secretarial couche. They were a fraction, if not the most powerful one, of the Egyptian ruling class, the 'large landowners'

139 Ibid., $84,88$.

140 Ibid., 92 and Table 13, 96-7.

141 Ibid., 93, 98.

142 Ibid., 99 .

143 Ibid., 106-8. 
analysed by Abbas and El-Dessouky. ${ }^{144}$ But they did not act as a distinct group or interest in the court politics of the period: Tahțāwī was exiled under Abbas and restored to office under Said, while 'Alī Mubārak was a member of Abbas's entourage and sacked on the accession of Said, 'like many other officials closely associated with Abbas' ${ }^{145}$ Even when a more principled formation than these court factions did emerge - in the nationalist agitation of the late $1870 \mathrm{~s}$ - it was not based upon these 'technicians'. The nationalist agitation in the press was 'primarily the work of religious leaders, teachers in the government schools, and Syrian Christians' (as well as being sponsored by the pretender Prince Abd al-Halim, Ismail's uncle). ${ }^{146}$ Those who supported Urabi in 1882 were the village shaykhs, army officers and middle-level bureaucrats - as well as the mass of the Egyptian people. ${ }^{147}$

\section{Bilād al-Shām: the 1850-61 conflicts}

In Bilād al-Shām a similar pattern can be discerned, though much more complex and with a different periodization. The 1830s saw the Egyptian invasion and rebellions against it; the 1840s both the restoration of Ottoman rule and the start of the Tanzimat; 1856-61 outbreaks of violence and the restoration of order under a settlement which endured, largely, until the 1880s. The Ottoman 'restoration' was in fact, as Masters has pointed out, the installation of a new kind of political control over the region, such as the Ottoman government had not previously attempted, and certainly not during the period of 'decentralisation' which had preceded it. Similar policies to Mehmed Ali's - conscription, uniform taxation - were now instituted. There followed a series of violent episodes, often complex and confused, but within which two opposed 'poles' can be discerned. ${ }^{148}$ On one side stood, firstly, the

144 The Large Landowning Class and the Peasantry in Egypt, 1837-1952.

145 Hunter, Egypt under the Khedives, 91, 127-30.

146 Ibid., 192-3.

147 Ibid., 229.

148 For the metaphor of 'poles' and 'fields of force' structuring a situation of social conflict, see Thompson, 'Eighteenth-Century English Society'151 and passim. 
'bourgeois' engaged in trade with Europe, as well as the Europeans and the Ottoman reformers. On the other stood those who were apparently being sidelined by the new economic and political order. This meant most obviously the lower orders dependent on what Masters calls a 'corporate' organisation of society (Huri Islamoglu-Inan points in particular to the 'artisans, urban lower-middle classes, lower bureaucrats ${ }^{149}$ ), but also to an extent the traditional 'notables' or patriciate.

These then formed the major 'poles' of the violent conflicts of the middle nineteenth century, and can be traced through the different episodes. In the Aleppo rebellion of 1850, the main participants in the violence were the inhabitants of the poor eastern suburbs of Aleppo. The role of the traditional Muslim notables appears to have been ambiguous: they did not take part in the violence, indeed the ashräf later intervened to suppress it, but there is some suggestion that the head of the Janissary faction may have tacitly supported the rioters. ${ }^{150}$ The initial animus was against the Ottoman attempt to introduce a census, thought to be a prelude to conscription, and 'rationalised' taxation: novel aspects of Ottoman state control over the city. The rioters then turned against Christians - but more specifically the Catholic Melchite Christians of the Judayda quarter - newly wealthy, linked to Europe, and separated from their neighbours. ${ }^{151}$ In the mind of the rioters, at least, there seems to have been an association between the newly rich and confident Christians, the rise in European power, and the extension of Ottoman state control of a new kind to the region with the Tanzimat.

This link, real or apparent, between the Christian merchants and the reforming officials had

149 The Ottoman Empire and the World-Economy (Cambridge: Cambridge University Press, 1987), 22. 150 Bruce Masters, 'The 1850 Events in Aleppo: An Aftershock of Syria's Incorporation into the Capitalist World System', International Journal of Middle East Studies 22, no. 1 (1990): 5; see also Feras Krimsti, 'The 1850 Uprising in Aleppo. Reconsidering the Explanatory Power of Sectarian Argumentations', in Urban Violence in the Middle East. Changing Cityscapes in the Transition from Empire to Nation State, ed. U. Freitag and N. Fuccaro (New York and Oxford: Berghahn, 2015), 141-63.

151 Masters, 'The 1850 Events in Aleppo', 4, 6, 17. Masters disagrees with Ma'oz's assumption that 'endemic sectarian tension' was 'a societal constant', and seeks a more proximate cause: 12 . 
already begun to appear during Ibrahim Pasha's occupation of Bilād al-Shām. ${ }^{152}$ Christians seem to have approved the new regime, and Muslims to have been dissatisfied with the Christians' rise in status. ${ }^{153}$ Both phenomena appear to have continued under the reimposition of Ottoman rule, coinciding with the Tanzimat. ${ }^{154} \mathrm{Ma}$ 'oz describes riots against Christians in Nablus, Gaza and Marash after the proclamation of the Hatt-i Humayun in 1856, which seem to have been provoked by what was seen as Christian and European arrogance. ${ }^{155}$ The linkage between Ottoman reform and Christian-European encroachment seems to have been clear. $^{156}$

In Damascus in 1860, again the violence was directed against a specific Christian quarter, Bab Tuma in the old city, and in particular against European consulates and missionaries. ${ }^{157}$ There was no overt protest against Ottoman reform in this case: rather, the relevant context is that of the existing sectarian violence in Mount Lebanon, from where large numbers of Christian refugees had fled to Damascus. ${ }^{158}$ Again, there is some doubt as to whether any of the notables were involved in inciting the violence; and certainly the Maydānīs and 'Abd alQādir al-Jazā' irī sheltered Christians. ${ }^{159}$

If this was one set of 'poles' around which the conflicts grew, however, there was another potential one which threatened to emerge. This was an outright class polarisation between

152 Moshe Ma'oz, Ottoman Reform in Syria and Palestine, 1840-1861: The Impact of the Tanzimat on Politics and Society (Oxford: Oxford University Press, 1968), 90-2, 17-18.

153 Bruce Masters, 'The Political Economy of Aleppo in an Age of Ottoman Reform', Journal of the Economic and Social History of the Orient 53, no. 1-2 (2010): 295-6 (citing the Christians Bakhkhāsh and Mishāqa and a Muslim alim's account); Ma'oz, Ottoman Reform in Syria and Palestine, 1840-1861, 18; Assaad J. Kayat, A Voice from Lebanon (London: Madden \& Company, 1847), 85, 88-9; see also Ma 'ūf's reference to a wave of Syrians resident in Egypt who returned to their homeland around this time, due to the favourable conditions produced by Ibrahim Pasha's government of Syria: 'al-Khūrì 'İsā Bitrū alŪrshalīmī', Majallat al-Ni 'ma, December 1911, 553.

154 Masters, 'Political Economy of Aleppo', 296-7.

$155 \mathrm{Ma}$ 'oz, Ottoman Reform in Syria and Palestine, 1840-1861, 226-8.

156 See, for instance, Schilcher, Families in Politics, 50.

157 Ibid., 87.

158 Ibid., 90-91.

159 Khoury, Urban Notables and Arab Nationalism, 23-5; Schilcher, Families in Politics, 96. 
the elites in general - the Ottoman state as well as the $a^{c} y \bar{a} n$ - and the commoners or general populace, 'awāmm or $a h \bar{a} l \bar{\imath}$, referred to contemptuously by the elites as the 'ignorant', juhhāl. The most worrying case was the Kisrawan rebellion under Tanyūs Shāhīn, from 1858: a rising of the (Maronite) ahālì against their (Maronite) shaykhs, without any 'notable' leadership at all. This may be seen to have points in common with, for instance, some events of the Greek revolution and other rebellions in the Ottoman Balkans: the alliance between popular classes and the middle class, the use of both 'Jacobin' and religious language. ${ }^{160}$ In Mount Lebanon in general, Makdisi refers to 'the evident breakdown of mechanisms of social control during the conflict of 1860 . [...] The great social distinction between high and low that had been the hallmark of the prereform society was temporarily abolished in the fighting. ${ }^{161}$ The threat of such an alternative 'polarisation' of social forces must have provided a strong incentive for all the 'elites' to find some common agreement. The bourgeoisie and intellectuals of Beirut were no exception, if their vocal support for Fuad Pasha is any indication: ${ }^{162}$ unlike part of the Maronite hierarchy and some of their counterparts in Kisrawan, they were no more prepared to side with the ahāli against the notables than they were to take part in Christian-Muslim or Christian-Druze sectarian violence.

\section{Bilād al-Shām: the restoration of order}

In the various restorations of order after the episodes of violence we can see the patterns of

160 For the mixture of people involved in the rebellion - peasants, rich farmers, the occasional merchant, and an 'anti-clerical and secular intellectual who publicly defended the ideas of the French Revolution' - plus some examples of French-inspired language, see Țarābulsī, A History of Modern Lebanon, 30-1; for an emphasis on the 'religiosity' of Shahin's 'social struggle', see Ussama Makdisi, 'Corrupting the Sublime Sultanate: The Revolt of Tanyus Shahin in Nineteenth-Century Ottoman Lebanon', Comparative Studies in Society and History 42, no. 1 (2000): 194.

161 Ussama Makdisi, The Culture of Sectarianism: Community, History, and Violence in Nineteenth-Century Ottoman Lebanon (Berkeley and Los Angeles: University of California Press, 2000), 135.

162 Fin de Siècle Beirut, 38-9. 
the subsequent period of accommodation and settlement appearing, as notables and Ottoman state allied to reassert control. In Aleppo, there was a split between different 'notable' factions, the Janissaries and ashräf-the latter 'now sided openly with the Turkish authorities'. ${ }^{163}$ When order was restored, with considerable violence, by the Ottoman troops, the Janissaries were 'excised from the historical record,' while 'The Ottoman authorities used the "events" to strengthen the faction of the $a s h r a \bar{f} f$ who had remained loyal to the House of Osman during the Egyptian occupation, most notably the Jābiri and Mudarris families, by appointing them to positions within the provincial administration. ${ }^{164}$ It was these families who were to go on to prosper in the subsequent decades, as beneficiaries of the land acquisition scheme of 1866 and members of the high Ottoman bureaucracy. ${ }^{165}$

In Damascus, the restoration of order was carried out energetically by Fuad Pasha under the eyes of the European Powers, and followed a similar pattern to that of Aleppo in 1850 . There were executions and exiles for the Muslim community and monetary compensation for the Christians. As in Aleppo, one pre-existing city faction (the 'Aẓms) was 'held responsible for the events and duly suppressed', while the other (the Maydānīs) 'remained unaffected or were even promoted'. The 'Azmms managed, nonetheless, to retain a significant role in political life. ${ }^{166}$

In Mount Lebanon, Makdisi describes the 'peace treaty' orchestrated by Khurshid Pasha in July 1860 as 'the first concerted effort by the local government and the local elites to regain the initiative from the local populace and restore a semblance of order.' It served to 'reinstate an imperial Ottoman authority over the natives' and to 'underscore the illegitimacy of the

163 Ma'oz, Ottoman Reform in Syria and Palestine, 1840-1861, 106. We should note that Ma'oz is far more willing than Masters to see the riots as an orchestrated plot by the Muslim notables.

164 'Political Economy of Aleppo', 299-300.

165 Ibid., 309; see also Sluglett, 'Modernity and Culture', 150.

166 Schilcher, Families in Politics, 101. 
popular mobilizations and restore a strict sectarian hierarchy'. ${ }^{167} \mathrm{He}$ continues: 'all the notables, Druzes and Maronites, could at least agree on one thing, that the ignorant "mobs" who had dominated politics of late could at last be silenced'. ${ }^{168}$ When the mutasarrifiyya of Mount Lebanon was created in June 1861, it nominally abolished the rank of muqataji; ${ }^{169}$ but 'Notable society survived its own formal abolition': in the new 'sectarian order', the notables were those who represented what were now considered as separate sectarian communities. Hence 'an elite political culture was reconsecrated', which barred the commoners from politics. ${ }^{170}$

These various restorations of order then created the conditions for a period of relative stability: in Mount Lebanon the 'Long Peace' referred to by Fawwāz Ṭarābulsīi, ${ }^{171}$ in the rest of Bilād al-Shām a period of elite politics. In Roger Owen's words, 'The response of both the Ottomans and the leading European powers to the upheavals of the 1850 s and 1860 led to an effort to create a new political and administrative order such as would provide a more secure framework for the growth of trade and the extension of commercial agriculture.' ${ }^{172}$ What Mahdī 'Āmil called a 'class adaptation', between the old ruling classes and the newly emerged bourgeoisie and reforming bureaucrats, allowed both the emergence of market relations and a 'bourgeois' public sphere, most notably in Beirut, and the perpetuation of the power of 'notables'. The transition from the 'moment of force', of violent restoration of order, to a 'moment of consent', had been accomplished. The relevant image was produced, as I shall argue below, by Fransīs Marrāsh in Ghābat al-Haqq.

The administrative expression of this accommodation was the provincial meclises, and in

167 Makdisi, Culture of Sectarianism, 142.

168 Ibid., 145.

169 Ibid., 159.

170 Ibid., 162.

171 Ṭarābulsī, A History of Modern Lebanon, 41.

172 The Middle East in the World Economy, 153. 
Mount Lebanon the peculiar political machinery of the mutasarrifiyya. These provided a framework within which notables could manoeuvre for power with the Ottoman governors without resorting to violence. If many of the notables retained much of their former power and position, they changed their manner of operating. This took the form of a double shift towards dependency on the market and on the central government. In these gradual developments we can see them accommodating to the two basic aspects of the new order, the world market and the new centralised state. In Aleppo, as already mentioned,

The principal beneficiaries of the land acquisition scheme put into place in Aleppo province after 1866 were the leading Muslim families who had supported the Ottoman regime.... Significantly, members of these families also held high government positions both in the province and at court during the Tanzimat era and the subse- quent reign of Sultan Abdülhamid II (1876-1909).

Those who acquired land also included Europeans, especially the Marcopoli and Poche families. ${ }^{173}$ The Ottoman bureaucracy, Sluglett points out, expanded greatly between the midcentury and the early twentieth century, providing positions for established families as well as relative upstarts. ${ }^{174}$ We should note also his conclusion that throughout the Hamidian period and well into the twentieth century, 'Although Muslims dominated politics, landowning and large parts of the wholesale grain trade, Christians and Jews continued to control banking, finance, and textiles in northern Syria....' 175

In Damascus, it seems that the notable families - not only the Maydānī families who had supported the Ottomans, but also the 'Aẓms - made a similar shift into bureaucratic positions and private landownership after 1860. In the late 1860s under the governorship of Rashid Pasha, many notable families were able to acquire property rights over vast rural estates. They also found employment and influence in the much-expanded Ottoman

173 Masters, 'Political Economy of Aleppo', 309; see also Sluglett, 'Modernity and Culture', 150. 174 Sluglett, 'Modernity and Culture', 146-7. 175 Ibid., 153. 
bureaucracy, dominating the majlis al-idāra and majlis al-baladiyya. ${ }^{176}$ These families constituted the 'landowning-bureaucratic' class referred to by Khoury; the role of the Christian or Jewish merchants would appear to have been less than at Aleppo. In Palestine, a similar pattern of transfer of conflict from armed warfare to the council chamber is discernible. ${ }^{177}$

The old and new notable families of Bilād al-Shām were thus able to reconcile themselves to increased Ottoman control - and control of a new kind - as well as to integration into the world market, by developing stakes in these new realities themselves. The Ottoman state became firmly implanted politically, and European capital took as firm a hold economically. The Christians of towns like Aleppo and Damascus were undoubtedly shaken by the violence of 1850 and 1860 - some left for the coast or the wider diaspora - but they continued to hold their place in local economic life, especially in Damascus. A symbiosis appears to have developed between Christians specialising in banking and commerce with Europe and Muslims in grain and livestock, and inland trade. They too appear to have accepted their place in the new-style Ottoman order, after the temptation and danger of European intervention receded. ${ }^{178}$ Though Northern Syria, like Lower Egypt, was becoming dependent on cash crop production for the world market, this actually strengthened the old landowning or tax-farming class. ${ }^{179}$ Though European economic involvement and the role of 'intermediaries' such as the Christian bourgeoisie increased, 'the impact of Western trade on the traditional structure of society was limited, as relations between the peasants and the landlords generally maintained their traditional features.' ${ }^{180}$ This suggests that we cannot yet

176 Schilcher, Families in Politics, 102-6.

177 Owen, The Middle East in the World Economy, 174.

178 There is an interesting account of one ideological adaptation to the later Ottoman order in Eugene Rogan's study of Mīkhā̄îl Mishāqa: 'Sectarianism and Social Conflict in Damascus: The 1860 Events

Reconsidered', Arabica 51, no. 4 (2004): 493-511.

179 'Silk and Agrarian Changes in Lebanon', 151.

180 Ibid., 160. 
speak of capitalist relations of production in agriculture, in these regions, although taxfarming 'notables' were able to turn themselves into 'landowner-bureaucrats' under a new Ottoman and world-market-oriented order.

\section{The place of Beirut in the post-1860 order}

Things appear to have been different for Mount Lebanon and the bourgeoisie of Beirut. The latter did not have the weight of established 'corporate' and notable interests of Aleppo or Damascus to contend with. We have already seen how it dominated the town council, to the exclusion of ulama and muqatajis. 1860 opened up considerable vistas to this class. The post-1860 Réglement organique drew the Mountain more firmly into Beirut's orbit; and this just at the time when French demand for silk was rising. ${ }^{181}$ Mount Lebanon was thus transformed, Kais Firro argues, into an area of 'silk monoculture'; ${ }^{182}$ and the main beneficiaries were the Beiruti bourgeoisie. The peasantry was able to acquire 'small plots of land' and gained in strength relative to the old muqatajis. But this led to their becoming dependent on the Beirut-based merchants and their brokers, who controlled the silk trade with France. ${ }^{183}$ The wealth of the landowners - that is, the traditional Druze muqataji families - decreased, as they too became dependent on the merchants and often fell into debt to them. ${ }^{184}$ This intensive monoculture production for the world market thus led (as with cotton in Lower Egypt) to 'qualitative... changes in cultivation': 'New methods of commercial transaction between the merchants and the peasants shook the traditional socioeconomic structure', and it seems probable that this did, in Mount Lebanon, entail peasant dependency upon the market, and thus capitalist agriculture in Wood's sense. ${ }^{185}$ The

181 The Middle East in the World Economy, 154, 163.

182 Firro, 'Silk and Agrarian Changes in Lebanon', 152, 154.

183 Ibid., 151, 157-9.

184 Ibid., 163-4.

185 Ibid., 160. 
silk-spinning factories also seem to have been a capitalist enterprise, employing waged (generally female) labour - though as Owen notes, family and 'traditional' links remained important. ${ }^{186}$

But this development of capitalist agriculture, if it took place, did not translate into an instant desire for political independence. As Hanssen argues, the Beiruti bourgeoisie generally aspired to 'an upgrading within the Ottoman provincial system'. ${ }^{187}$ The 'Ottomanists', such as Bustānī or the Marrāsh of Ghābat al-Haqq, appear far more representative of the bourgeoisie of Beirut and Bilād al-Shām, in the 1860s or 70s, than those arguing for some form of foreign protectorate. The Tanzimat, coupled with the suppression of the violence of 1850-61, had in fact substantially consolidated the Ottoman grip on Syria. Financially, of course, the Empire, like Egypt, was being eaten away by Europe, but its political control seemed for the moment firm: Syria would not be another Greece. European interference had not vanished, but its mode was different: one way of registering the change is to note that Richard Wood, the British consul and political intriguer of the 1830s and 1840s, was supplanted after 1860 by J. Lewis Farley, the projector of financial schemes. ${ }^{188}$

\section{A capitalist class?}

One of the groups we have been discussing - the mainly Christian merchants of Beirut and Bilād al-Shām - has often been called, in a loose sense, a 'bourgeoisie', and I have followed this practice. It may even make sense to see the 'new social groups', taken together, as a

\footnotetext{
186 Roger Owen, 'Lebanese Silk Industry', in The Ottoman Empire and the World-Economy, ed. Huri Islamogu-Inan (Cambridge: Cambridge University Press, 1989).

187 Fin de Siècle Beirut, 53.

188 For Wood's activities, see the many references in Ceasar E. Farah, Politics of Interventionism in Ottoman Lebanon, 1830-1861 (London: IB Tauris, 2000); an example of Farley's commercial prospectuses is The Resources of Turkey Considered with Especial Reference to the Profitable Investment of Capital in the Ottoman Empire (London: Longman, Green, Longman and Roberts, 1862).
} 
'propertied and educated bourgeoisie' (Besitz- and Bildungsbuergertum). ${ }^{189}$ But these are social and cultural definitions rather than strictly economic ones. Are we looking here at a capitalist class? Much of the wealth of the Beiruti bourgeoisie does indeed seem to have been derived from the market economy, rather than from extra-economic sources such as tax-farming, despite its diversity of interests. Most importantly, in Mount Lebanon and in the leading sector of silk cultivation and primary industrial processing (spinning), we can see it intervening directly in the production process, and apparently beginning to create both capitalist agriculture and industrial production, in the place of the traditional peasant-lord or craftsman-guild relationships. In this area, at least, it would appear to be gradually moving beyond its earlier confinement to the sphere of trade and exchange.

What of the Ottoman-Egyptian elite under Mehmed Ali and his successors? Mehmed Ali's regime, then, although innovatory, and externally oriented towards the capitalist world market, was not capitalist in its internal relations of production: extra-economic modes of extraction and privilege dominated over 'free labour' and competition. Like the serf empires of Eastern Europe, or that other great cotton-producing economy, the slave states of the American South, it may be seen as an innovatory productive regime, which would not have existed without the capitalist world-market, but which was not itself capitalist (on the definition of Ellen Wood, or Maurice Dobb). ${ }^{190}$ Its ruling class derived its authority, under Mehmed Ali, from the dynasty and state apparatus. Men began their careers as servants (or members) of the dynasty and were rewarded with land: they did not start out as landowners and assert their control over the state.

189 Franco Moretti, The Bourgeois : Between History and Literature (London: Verso, 2013), 3; E. J. Hobsbawm, The Age of Empire, 1875-1914 (London: Weidenfeld \& Nicolson, 1987), 172.

190 See the suggestive remarks of Elizabeth Fox-Genovese and Eugene D. Genovese, Fruits of Merchant Capital: Slavery and Bourgeois Property in the Rise and Expansion of Capitalism (New York: Oxford University Press, 1983); and Manisha Sinha, 'Eugene D. Genovese: The Mind of a Marxist Conservative', Radical History Review 88, no. 1 (2004): 4-29. 
Yet this Ottoman-Egyptian 'service elite' seems to have made a gradual transition to capitalist agriculture, transforming itself into a 'big landowning' class by the end of the nineteenth century. Economic incentives and relations replaced corvée and serf-like ones in the countryside; private property in land became more secure, and landowners somewhat less dependent on state and court. Some point in Ismail's reign might be the most plausible point for the crucial moment of this transition. Thus 1860 for Beirut and Bilād al-Shām, and some point in Ismail's reign for Egypt, might be regarded as the tipping-points, beyond which the development of capitalism was to accelerate. It seems plausible, too, that these points could correlate with the notional point of 'incorporation' of the region into the capitalist world-system.

\section{The Dialectic of Dependency}

We may now turn to the vexed question of the 'dependency' of the classes which created the Nahda upon Europe - the crux of 'Āmil's original argument, which we recall posited, like those of other dependency theorists, the existence of a distinct type of 'colonial bourgeoisie' fundamentally dependent on colonialism. We have already seen a certain amount of evidence qualifying this claim; and we may note that it has been disputed, for another part of the Ottoman Empire, by Reşat Kasaba, one of Wallerstein's original collaborators on Ottoman matters: he argues that the Levantine bourgeoisies of Anatolia, rather than being a mere 'comprador' class, were a 'bourgeoisie in their own right'. ${ }^{191}$ Though he does not refer to this argument, Jens Hanssen seems to be following a similar line in his account of the Beirut 'intermediary bourgeoisie', as does Elizabeth Holt in her account of an 'emergent bourgeois

191 Reşat Kasaba, 'Was There a Compradore Bourgeoisie in Mid-Nineteenth-Century Western Anatolia?', Review (Fernand Braudel Center), 1988, 215-28. 
reading public'. ${ }^{192}$ Other recent studies, mainly dealing with a later period than that under discussion here, have similarly attempted to shift the emphasis onto the agency of local groups: Keith Watenpaugh's Being Modern in the Middle East, Lucie Ryzova's The Age of the Efendiyya, Ilham Khuri-Makdisi's The Eastern Mediterranean and the Making of Global Radicalism. ${ }^{193}$

\section{Hegemony, collaboration, and resistance}

One initial distinction that has to be made is that between the general conditions of the hegemony of European peoples and the dependency of non-European ones, and the place of particular classes and groups within these conditions. In his wider argument, as to the incorporation of the Ottoman-Arab world into a capitalist world market dominated by Europe, 'Āmil can hardly be refuted. The process of economic change and class 'adaptation' outlined above was indeed determined by a capitalist and imperialist logic which was reshaping the Arab-Ottoman countries in ways acceptable and useful to the world economy and the European powers which dominated it. The rise of the new bourgeoisie trading with Europe, the shift of established notables into dependency on the market, the imbrication of the Ottoman and Egyptian (and for that matter Tunisian) governments in the toils of European finance, were all forms of this adaptation. We might add, beyond the strictly economic argument, that this was bound up with the implantation of Western-derived political and cultural forms: the 'modern scientific governing machine' ${ }^{194}$ of censuses,

192 Hanssen insists that Beirut 'emerged as neither driftwood on the sea of world-economic forces or as the natural product of Ottoman imperial fiat. Rather it was a city of its own making.' Fin de Siècle Beirut, 53; Holt, 'Narrative and the Reading Public in 1870s Beirut'; For a useful account of the historiographical debate, see Athanasios (Sakis) Gekas, 'Class and Cosmopolitanism: The Historiographical Fortunes of Merchants in Eastern Mediterranean Ports', Mediterranean Historical Review 24, no. 2 (2009): 95-114.

193 Keith David Watenpaugh, Being Modern in the Middle East : Revolution, Nationalism, Colonialism, and the Arab Middle Class (Princeton: Princeton University Press, 2006); Lucie Ryzova, The Age of the Efendiyya: Passages to Modernity in National-Colonial Egypt (Oxford University Press, 2013); KhuriMakdisi, The Eastern Mediterranean and the Making of Global Radicalism.

194 The expression is that of an observer of the Ottoman Empire in the 1830s, the English naval officer Adolphus Slade, cited in Bernard Lewis, The Emergence of Modern Turkey (London: Oxford University Press, 1968), 74. 
conscription, rational taxation, formal law codes, cadastral surveys; and a new public sphere of newspapers, theatres, learned societies, and the other institutions, precisely, of the 'Nahda'. All of these are recognisably forms which originated in Europe and remained dependent to a great extent on European models. By the end of the nineteenth century, they proved the means of a formidable economic, political and cultural hegemony of the West over the Arab-Ottoman lands, as over much of the rest of the globe.

The fact of this hegemony is not in dispute. Nor is the substantial role played by bourgeois, bureaucrats and intellectuals in its implantation. What is at issue is rather the degree of reciprocity within the hegemonic relationship: the extent to which these local elites or privileged groups were in fact able to profit from it, rather than being its victims. There is also the associated distinction between Western means and Western ends: the adoption of the one did not necessarily mean acquiescence in the other. For the very existence of these local bourgeois, officials and intellectual elites indicates that this was a situation of Western hegemony, rather than direct and unmediated domination: Western power may have been ultimately dominant, but it was imposed, for these countries in this period, at one remove. And as with any hegemony, not all the subordinate or 'subaltern' groups were wholly powerless: 'both parties to the equation,' as Edward Thompson once put it, 'were, in some degree, the prisoners of each other'. ${ }^{195}$

This does not mean that there were not very clear limits to the possibilities of action of these subordinate groups, or that they were not subject to strong pressures to conform to needs and desires that had their origin outside them, among the ruling classes of the West. But we should be wary of posing the question simply in terms of the dependency of these (Arab, non-Western) countries, as a single bloc, upon those (European, Western) countries, as 
another bloc. We have to look more specifically at the place of different classes, groups, and social organisations within the conditions of hegemony. And the prior history of the groups that created the Nahda - 'Āmil's 'harbingers' of capitalist development - may prove more relevant to understanding the mode of implantation of capitalism and its concomitants in the region than 'Āmil suggests.

\section{The merchants: compradors or 'bourgeoisie in their own right'?}

The integration of the Arab countries into the world market was from the first bound up with their general 'dependence' on Europe. One of the very first 'nuclei' of the market economy in Bilād al-Shām, Fakhr al-Dīn II al-Ma 'nī’s development of the silk industry, was of course designed for the export of silk to Europe (the Italian city-states) for cash, and involved the implantation of European trading colonies in centres such as Sidon. ${ }^{196}$ Philipp locates a point of transition at the end of the eighteenth century: until then,

the "nation" of the French merchants showed great similarities in structure and functioning to the millets, guilds and other segments of indigenous society. In the nineteenth century, and not least because of a perceived shift in the balance of power, Europeans become more privileged and a completely protected elite. ${ }^{197}$

But even in the eighteenth century, the success of the Syrian Christian trading diaspora 'was tied largely to the growing influence of the West in Ottoman international trade. Unlike the Armenians who had traded as equals with the English factors a century before, these Levantine communities were usually subordinate to Western European commercial interests, serving as agents and middlemen.' ${ }^{198}$ The most frequently suggested reasons for the link between the growing European domination of the Levant trade and the rise of the Arab Christians are that Christians could obtain consular protection from European powers, giving

196 Țarābulsī, A History of Modern Lebanon, 8.

197 'Bilad al-Sam in the Modern Period', 417.

198 Masters, 'Trading Diasporas and "Nations", 365. 
them tax exemption; and Europeans tended to favour Christians as trading partners. ${ }^{199}$ But we can also find much evidence that points to a more variable link between local Christians and Europeans: not only Syrian Christians and Frenchmen working as trading partners together, but also coming into direct competition. Heyberger writes: 'Lorsqu'au XVIIIe siècle des Orientaux connaissent une ascension rapide dans le commerce, méditerrannéen, il arrive aux marchands des Echelles de les considérer comme de redoutables concurrents. ${ }^{200}$ Philipp notes that this was the case for the Damietta textile trade in the early eighteenth century, ${ }^{201}$ in Aleppo, according to Masters, 'The English ... were extremely reluctant to follow such a policy [of granting consular berats to local merchants] ... most letters from Levant Company factors clearly express the fear that the practice must in the end injure English merchants, who would find themselves in competition with such "honorary" Englishmen'. ${ }^{202}$

Nor were these fears unfounded. In the nineteenth century, especially in Beirut, many Syrian bourgeois who had begun as agents or protégés of European merchants and consuls became merchants in their own right and entered into direct competition with their former employers. ${ }^{203}$ As Zachs says, they began by exploiting to the full the protection of Western consulates and their status of intermediaries, which gave them an advantage over other local merchants. ${ }^{204}$ Their rise, as we have noted, was linked to the decline of the muqatajis as well as the exploitation of farmers and silk-workers. But they then used this position to outcompete the Europeans themselves. A British vice-consul noted sadly in 1871:

The competition of the native has driven the Englishmen off the field. Equal, if not greater, facilities given by the home manufacturer, cheaper

199 Ibid., 357-358, 364.

200 Les Chrétiens Du Proche-Orient, 259.

201 The Syrians in Egypt, 1725-1975, 16-18, 23-24.

202 'Trading Diasporas and "Nations"', 359.

203 This process is documented in Robert M. Haddad, Syrian Christians in Muslim Society: An Interpretation (Princeton: Princeton University Press, 1970), 36-47.

204 Making of a Syrian Identity, 56-7. 
modes of living, and consequent requirement of a smaller profit, looser ways of doing business in many instances, have all combined in the face of the increased import trade with Great Britain, to enable the native to compete successfully with the Englishman. ${ }^{205}$

Thus, in contrast to other coastal cities of the Eastern Mediterranean, where investment and profit were largely in foreign hands, in Beirut 'the local merchants...accumulated great wealth, some of which they re-invested in the city.' ${ }^{206}$ Just as striking is their takeover of the silk factory sector, from the 1850 s to the late 1860 s. ${ }^{207}$

But Owen insists: 'whatever the pattern of ownership, the industry as a whole remained firmly subservient to French capital and French commercial interests' ${ }^{208}$ Again, we must be specific about whose interests this means. They were not, for instance, in any substantial sense the interests of the workers in the French silk industry. It is true that the ouvriers en soie, in Lyons above all, had by the mid-century built up an impressive position for themselves: with their political and cultural organisations, their newspapers full of SaintSimonian and Fourierist ideas, their strikes and their two great rebellions of the 1830s, they were among the most militant working-class communities anywhere - certainly far more organised and redoubtable than any of the workers or peasantry of Mount Lebanon. ${ }^{209}$ But the control and direction of the industry still remained in the hands of the fabricants, the capitalist silk manufacturers: the workers' strength was doubtless an important factor in their calculations, but it was a factor that they took into account in deciding their priorities. In this situation, the merchants of Beirut - as of other silk-supplying countries - appear as partners, albeit junior and subordinate partners, of the French capitalists, while the silk-workers of Lyons, along with the silk-growers and spinners of Mount Lebanon, were exploited

205 Cited in Charles Issawi, 'British Trade and the Rise of Beirut, 1830-1860', International Journal of Middle East Studies 8, no. 1 (1977): 99.

206 Zachs, Making of a Syrian Identity, 195.

207 See Owen, cited in Issawi, 'British Trade and the Rise of Beirut', 99.

208 The Middle East in the World Economy, 159.

209 See, for instance, Mary Lynn McDougall, 'Consciousness and Community: The Workers of Lyon, 18301850', Journal of Social History 12, no. 1 (1978): 129-45. 
labourers. To describe the situation as one simply of 'French hegemony over Mount Lebanon', or of 'Mount Lebanon's dependency on France', is then a radical oversimplification. It was the domination of the French bourgeoisie, in varying degrees, over the Beiruti bourgeois, the Lyons workers, and the peasantry and silk-spinners of Mount Lebanon. A similar picture could be drawn for the cotton industry, with the capitalists of Manchester exercising ultimate control, with their junior partners the landowners and (mainly non-Egyptian) bourgeoisie of Egypt - as well as other cotton suppliers such as the slave-holders of the Old American South - and their labour force the Lancashire factory workers, the Egyptian peasantry, and the Southern slaves. And in between one finds, of course, a vast array of 'middle-class' or 'petit-bourgeois' groups: brokers, ginners, lawyers, technicians, foremen, shopkeepers.

We can then posit that the bourgeoisie of Beirut had its own local hegemony over the city, the Mountain and to some degree interior Syria, which was nonetheless contained within a general hegemony of the European and specifically the French bourgeoisie. The existence of this local hegemony is borne out by the evidence presented by Hanssen. He gives many examples of the participation of Beiruti capitalists with Europeans resident in Beirut (such as de Perthuis), in projects for port construction, railways, municipal lighting. ${ }^{210}$ The first Beiruti bank was founded by Pharaon and Chiha in $1876 .{ }^{211}$ Even in the great concessionary enterprises and financial schemes that were leading, in a general sense, to European financial control over the Ottoman Empire, the Beiruti bourgeois had a foothold.

This collaboration appears to have led to the development of a local, Beiruti interest shared by both 'natives' and Europeans established in Beirut such as de Perthuis. The latter, along

210 Fin de Siècle Beirut, 88-99.

211 Fawwāz Ṭarābulsī, Șilāt bilā Wașl: Mīshāl Shīhā wa-l-īdiyūlüjiyā al-Lubnāniyya (Unconnected Links: Michel Chiha and the Lebanese Ideology) (Beirut: Riyāḍ al-Rayyis, 1999), 16-17. 
with the Austrian Laurella, was a member of the Beirut municipality, and as such made a 'staunch criticism' of 'his fellow foreign residents who refused to pay their share of municipal taxes'. This leads Hanssen to argue that in Beirut, unlike other port cities such as Alexandria where foreign interests absorbed local ones, 'the municipality incorporated or absorbed the interests of what were arguably Beirut's most influential foreign residents'. ${ }^{212}$ This is borne out by Bustān̄̄'s remark in 1869 that

in Beirut there are persons of different countries and races ... these fall into two groups: Easterners and Westerners. Though they may differ in their nationality and tastes, they have common interests, especially in trade, civic [or: political] life and culture [or: morals]; and if they wish, they may live together in security, ease, affluence and prosperity. ${ }^{213}$

There was quite clearly an identity of interests between Syrian and European bourgeois, as against the 'rabble'. And this absence of antagonism between 'Western' and 'Eastern' bourgeois can be explained simply enough: overriding all their 'national' or 'colonial' interests was the fact that these were capitalists: they were acting in the interests of making money, and money has no homeland.

Again, we have to point to the fact that all of these bourgeois - Syrians and Westerners were engaged in diasporic trade networks across the Mediterranean and indeed, by this stage, across the globe. It is not very helpful to think of the Syrian bourgeois as representatives of some 'national' interest, as against a French or European (or Ottoman) interest - for they were by no means limited to one city or territory, 'national' or otherwise. Their diasporic qualities, already in evidence from their rise in the eighteenth century, expanded still further in the nineteenth. As well as one centre - Beirut - where they were locally hegemonic and relatively independent, they shared in the growth and wealth of a number of other centres: in the Mediterranean, Alexandria, Istanbul, Cairo; and further afield, Manchester, Buenos Aires, 
New York. ${ }^{214}$ If we look at this whole picture, including the diaspora, we can see their

bourgeois 'experience' as more impressive than appears if we look merely at one centre,

even if that centre is Beirut. Perhaps the European capitalists were less interested in trade by this stage because there was bigger money to be made in extortionate loans to the Egyptian and Ottoman governments, or to individual rulers like Ismail. ${ }^{215}$ But still the Syrians had succeeded in carving out a space for themselves in this imperial world.

Nor was it only a 'local' space, in Syria itself. By the end of the nineteenth century, the most successful of these families were involved in high society, high finance, and imperial policy: the de Bustroses, Pharaons, Malhamés, Sursocks, Șabbāghs. ${ }^{216}$ These 'Levantines' had gained a place, if a minor one, in the 'consolidated plutocracy' of the high imperial era. ${ }^{217}$ More successful perhaps than any of them, perhaps, was the Baghdadi Jewish family of the Sassoons, known in the nineteenth century as the 'Rothschilds of the East', who ended up as part of British high society. ${ }^{218}$ It is worth noting that many of these families were already established in financial and political power in the early nineteenth or eighteenth centuries:

David Sassoon the treasurer to the Mamluk governors of Baghdad, the Pharaons already possessing a large trading empire in the eighteenth century, Ibrahim al-Ṣabbāgh chancellor to

214 The literature on this is extensive: for Manchester in the nineteenth centuries see Fred Halliday, 'The Millet of Manchester: Arab Merchants and Cotton Trade', British Journal of Middle Eastern Studies 19, no. 2 (1992): 159-76; for other centres see Dalia Abdelhady, The Lebanese Diaspora: The Arab Immigrant Experience in Montreal, New York, and Paris (New York: NYU Press, 2011); Michael Humphrey, 'Lebanese Identities: Between Cities, Nations and Trans-Nations', Arab Studies Quarterly, 2004, 31-50.

215 See for instance the classic account by David S. Landes, Bankers and Pashas: International Finance and Economic Imperialism in Egypt (Cambridge, MA: Harvard University Press, 1958).

216 Hanssen, Fin de Siècle Beirut, 99 describes the Șabbāghs and Malhamés as 'international power brokers'; see also his "Malhamé-malfamé": Levantine Elites and Transimperial Networks on the Eve of the Young Turk Revolution', International Journal of Middle East Studies 43, no. 1 (2011): 25-48; see Samir Kassir, Beirut (Berkeley: University of California Press, 2010), 205-6 for Alfred Sursock (and the Salāms); and for Selim de Bustros, who had Tsars as godfathers to his children, Zachs, 'Cultural and Conceptual Contributions'.

217 V. G. Kiernan, Marxism and Imperialism: Studies (London: Edward Arnold, 1974), 76.

218 Stanley Jackson, The Sassoons (New York: Dutton, 1968); Cecil Roth, The Sassoon Dynasty (New York: Arno Press, 1977); much of their wealth came from the opium trade opened by British imperial force with China: Maisie Meyer, 'Baghdadi Jewish Merchants in Shanghai and the Opium Trade', Jewish Culture and History 2, no. 1 (1999): 58-71; Sarah Abrevaya Stein, 'Protected Persons? The Baghdadi Jewish Diaspora, the British State, and the Persistence of Empire', The American Historical Review 116, no. 1 (2011): 80108. 
Zāhir al-Umar of Acre. They were successful in maintaining their position under the very different conditions of capitalism and European imperialism.

In the light of these qualifications we can perhaps generalise: these bourgeois were dependent upon contact with Europe but not necessarily on European domination. Where this domination advanced their interests, they collaborated with it and made use of it, forcing out muqatajis, craftsmen, and other merchants. But where they could compete directly with Europeans (and thus cease to be simply 'compradors') they did, and built up considerable fortunes and centres of power and culture such as Beirut, as well as far-reaching networks across the globe. We can suggest that there was a dialectic between these Levantine middlemen and European capitalists, even if it was ultimately one in which the Europeans had the upper hand. The Europeans could not in fact operate successfully in Syria without the Levantines - just as, for instance, the Christians of Beirut seem to have relied on Muslims for much of their inland trade. And there is a sense in which European capitalists and for that matter the European industrial workers they employed -were 'dependent' on countries such as the Arab ones for raw materials and markets - I am thinking, for instance, of the cotton famine of the 1860 s.

There were of course distinct limits to this local hegemony, to the extent to which the Syrian bourgeoisie could act 'in its own right'. The capitalists of the Arab world remained commercial, financial, and agricultural capitalists: in Lebanon, as in Egypt, 'such industry as existed consisted almost entirely of the processing of agricultural produce'. ${ }^{219}$ The limits of the Lebanese silk manufacturing system, social as much as technical, have also been pointed out by Owen. ${ }^{220}$ The relevant comparison is with the Japanese experience, where the local

219 Owen, Cotton and the Egyptian Economy, 1820-1914, xxv. 220 Owen, 'Lebanese Silk Industry'. 
bourgeoisie was able to industrialise the country along the most advanced lines itself.

\section{The reforming officials: between Europe and the dynasty}

Secondly, we have to consider more briefly the Ottoman and Alid reforming bureaucrats in the aspect of their relations to Europe. Many have stressed the extent to which the reformers specifically, and the reforms they proposed, were the creatures of European interests and ideas. Hourani has noted that it was the ideas particularly of the bureaucrats 'who had been trained as diplomats or translators' that governed the 'new administrative system': i.e. the ideas of those who had been in contact with Europe and European methods of administration. ${ }^{221}$ In practical terms many of the reforms of Mehmed Ali and the Ottomans, in the army as well as the civil bureaucracy, were dependent on European expertise. Bernard Lewis has also stressed the extent to which the Tanzimat were the product of those in the Ottoman bureaucracy who had contact with Europe and Europeans, ${ }^{222}$ and also the extent to which they and their reforms were strengthened against their rivals within the Ottoman ruling groups by European pressure. ${ }^{223} \mathrm{He}$ concludes that 'the reforms were basically the forcible imposition, on a Muslim country, of practices and procedures derived from Europe, with the encouragement, if not the insistence, of European powers, and with the help of European experts and advisers.' 224

As in the case of the bourgeoisie, though, we have to note a certain freedom of action, within serious constraining limits. These limits were reached, for instance, by Mehmed Ali in 1839,

221 'Ottoman Reform and the Politics of Notables', 99; he is following Şerif Mardin, The Genesis of Young Ottoman Thought: A Study in the Modernization of Turkish Political Ideas (Syracuse, NY: Syracuse University Press, 1962).

222 The Emergence of Modern Turkey, 88-89.

223 Ibid., 106-7, 115-6, 121.

224 Ibid., 217. 
and by the Egyptian nationalists in 1882; the various constraints imposed on the Ottomans, the loss of provinces, the continuation of the Capitulations or other trade agreements similarly useful to Europeans, are sufficiently known. But this does not make the project of the reformers simply a 'European' or 'colonial' project. The presence of 'local', Ottoman or Islamic elements in the Tanzimat reforms, for instance, has been the subject of more recent studies. ${ }^{225}$ For the Hamidian period, Selim Deringil has emphasised that all Ottoman officials shared the basic concern of 'saving the Empire' from disintegration due to European pressure. ${ }^{226}$ As argued above, the Ottomans did succeed in consolidating their control over Syria after 1860, in contrast to their loss of the Greek and Balkan provinces; this political consolidation, however, went along with a loss of control of the Empire's economy and finances. ${ }^{227}$ Again, given the imbrication of European and Ottoman, political and financial interests, demonstrated for instance in the case of the Malhamé brothers later in the century, ${ }^{228}$ we may ask whether we are not looking at a symbiosis of 'Western' and 'Eastern' ruling classes, albeit an unequal one, rather than the subjugation of one 'nation' by others.

In a similar vein, Khaled Fahmy has argued that it is not reasonable to see Mehmed Ali's dynastic project as an Egyptian national project, and that, rather than being the victim of a 'defeat' of the Egyptian nation at the hands of the British in 1839 , he was in fact relatively successful in establishing his dynasty as a hereditary one in Egypt. ${ }^{229}$ In the age of Ismail, the close links between the Khedivial family and ruling elite on the one hand, and European financial and political interests on the other, point to a similar kind of symbiosis, though an

225 Butrus Abu-Manneh, 'The Islamic Roots of the Gülhane Rescript', Die Welt Des Islams 34, no. 2 (1994):

173-203; Frederick F. Anscombe, 'Islam and the Age of Ottoman Reform', Past \& Present 208, no. 1 (2010): 159-89.

226 The Well-Protected Domains: Ideology and the Legitimation of Power in the Ottoman Empire, 1876-1909 (London: IB Tauris, 1998).

227 Masters, 'Political Economy of Aleppo'.

228 Hanssen, "Malhamé-malfamé",.

229 All the Pasha's Men, 305. 
unequal and unstable one. ${ }^{230}$

\section{Towards the twentieth century: 'class differentiation'}

Finally, in order to make a few crucial links, we must consider briefly what became of the social groups and formations discussed above in the latter part of the nineteenth and the beginning of the twentieth century. This was a period in which many of the phenomena which had come into being in the 1860s changed significantly, though few disappeared. The financial control of Europe over the Ottoman Empire, Egypt and Tunisia, which had grown through the middle decades of the century, now took on a more explicitly political aspect, with the occupations of Egypt by the British and Tunisia by the French. This opened a new age of European imperial competition, which saw growing tensions between the powers and more explicit national and imperial ideologies. The 'Hamidian despotism' and the new Ottoman emphasis on the Caliphate can be seen as part of this trend. This was also the period of the emergence as a definite presence of a new social class in Bilād al-Shām and Egypt: what 'Âmil calls the 'petite bourgeoisie', Watenpaugh the 'middle class', Ryzova the 'efendiyya'. 'Âmil sees this as arising from a process of 'class differentiation' within the bourgeoisie that had grown up in the earlier nineteenth century. The 'colonial bourgeoisie' or 'grande bourgeoisie' separated out from the 'middle class'.

Something of the sort indeed seems to have happened. From the later 1870 s to the end of the nineteenth century, Philipp notes that the Syrian intelligentsia in Egypt was largely divorced from the wider Syrian bourgeoisie: it no longer expressed the interests of the latter. ${ }^{231}$ After

230 Hunter, Egypt under the Khedives, 114-7.

231 The Syrians in Egypt, 1725-1975, 100-2, 119. 
the 1870s 'watershed', it was to some extent engaged in a new kind of popular journalism with a wider readership. This was also in many cases an explicitly nationalist press, associated as well as the Syrians with Egyptian radicals such as 'Abdallāh al-Nadīm and James Sanua, and it possessed, apparently, a 'lower-middle-class' kind of social base; while the landowners and bureaucrats were more clearly identified with the Khedivial dynasty and European interests. ${ }^{232}$ Ilham Khuri-Makdisi describes certain of the 'radical' milieux in Egypt and Bilād al-Shām who were clearly opposed to the ruling classes and imperial rule. Her account of the circle around one Beiruti newspaper delineates, precisely, a social base for radical intellectuals among the professional classes. ${ }^{233}$ In other words, the two 'sub-strata' which Zachs saw, in Beirut in the mid-nineteenth century, as very much linked - the merchants and big capitalists on the one hand, and the petite bourgeoisie of professionals and intellectuals on the other - were drifting apart.

This kind of division is better understood, I would suggest, as a class rather than a national/colonial or native/foreign divide. The prominence of a group of Syrian journalists and writers in the formation of an Egyptian 'national' intelligentsia, press, and theatre, and in political nationalism, is one indicator of this. As Khuri-Makdisi shows, there was a common 'radicalism' among other foreigners of the professional and lower-middle classes, such as the Italians in Alexandria. The foreign community did not side with the rulers (and the British Empire) en bloc, but split into its class components: the wealthy Syrian or Italian grande bourgeoisie closely linked to the status quo, the professionals, intellectuals and little men becoming 'radicals'. And the critique made by these 'radicals' of their societies did not reduce itself simply to a 'national' or nationalist position, as against imperialism. Antiimperialism was an important part of their discourse, but as Khuri-Makdisi argues, that they

232 Hafez, The Genesis of Arabic Narrative Discourse, 117-125.

233 The Eastern Mediterranean and the Making of Global Radicalism, Chapter 4. 
were working within a global context of radical politics. Cooperativism, workers' education, anticlericalism, socialism, anarchism (though I suspect Khuri-Makdisi overplays the significance of the latter), all had a role in their activities.

This variety of their discourse also points to another aspect of this later period, towards the end of the century, when compared with the 1860 s. It was not simply a question of class differentiation, though it seems that this was a decisive underlying factor. Ideological fissures of various kinds were opening up between positions which had previously appeared to be allied, or at least non-contradictory. This was the period of the Hamidian despotism and the split this caused in the Ottoman ruling elite; ${ }^{234}$ of Turkification and the Arab nationalist response; of anticlericalism, as Khuri-Makdisi notes; and of the kind of polarisation between 'westernised' and 'traditional' groups represented by the Egyptian contrast between the 'tarbush and the turban'. ${ }^{235}$ The latter then had its ramifications in the debates between science and religion, materialism and spiritualism, and so forth. ${ }^{236}$ Many of these elements had coexisted without apparent strain in the 1860s and previously: Turkish and Arab reformers working together, Churchmen and laymen, Ṭahțāwī the Azhari translating European scientific and humanistic knowledge. Of course there were many, like 'Abduh, who tried to keep the two sides of the question together, but there is a sense of strain which was not so obvious in the earlier decades of the century. In many ways, this was a period when - to use the metaphor of the New Historicists ${ }^{237}$ - fissures which previously had been mere hairline fractures opened up into great rifts.

234 Hourani, 'Ottoman Reform and the Politics of Notables', 100.

235 Anshuman A. Mondal, 'Between Turban and Tarbush: Modernity and the Anxieties of Transition in Hadith 'Isa Ibn Hisham', Alif, no. 17 (1997): 201-21; Ryzova, Age of the Efendiyya.

236 See, for instance, Marwa Elshakry, Reading Darwin in Arabic, 1860-1950 (Chicago and London: University of Chicago Press, 2013); M. Şükrü Hanioğlu, 'Blueprints for a Future Society: Late Ottoman Materialists on Science, Religion, and Art', in Late Ottoman Society: The Intellectual Legacy, ed. Elisabeth Özdalga (Abingdon: Routledge Curzon, 2005), 28-116. 237 See Terence Cave, Pré-Histoires: Textes Troublés Au Seuil de La Modernité, vol. 1 (Geneva: Droz, 1999). 


\section{Conclusion, or a further hypothesis}

We are now in a position to put forward a tentative answer to the questions raised initially by 'Âmil, and which I have attempted to follow through the historical evidence. The following should be taken less as a firm conclusion than as another hypothesis, for future investigation. But it appears to me to fit the facts we have examined in this chapter.

In the eighteenth and the first half of the nineteenth century, the mode of production that predominated over the Arab-Ottoman lands was - though neither 'feudal' nor 'orientaldespotic' - of the genus described by Eric Wolf as 'tributary'. This mode of production was basically dependent upon extra-economic forms of appropriation and power: tax-farming, urban privileges, guilds and orders. Though merchant capital existed in the form of native trading and moneylending classes, market relations did not yet predominate over these extraeconomic relations. But the merchant capital sector - and especially the mainly Christian diasporas trading with Europe - was growing in wealth, particularly, by the 1850s, in Beirut; so was the 'new' officialdom and innovating dynasties (like Mehmed Ali's) which looked to Europe; and the principal reason in both cases was that the region was becoming ever more imbricated both in the capitalist world-market and in the toils of European diplomatic and military imperialism. Beyond a certain critical point - say, the 1860 violence for Bilād alShām, and some point in the reign of Ismail for Egypt - these largely external influences became the decisive factors over the whole area, and it is plausible to see it as having been incorporated, albeit unevenly, into the capitalist world-system. To this system the ruling classes, old and new, had after this point to adapt.

But - and here I differ from 'Āmil - this incorporation did not simply cancel out the prior history of the society: more particularly of the merchants engaged in trade with Europe, the 
bureaucratic elites which adopted so many of its modes in government, and the 'intellectuals' of the Nahda. These, Bārūt's 'new social groups', succeeded in carving out for themselves a significant though subordinate position in the Arab-Ottoman (and increasingly Europeandominated) territories. More especially, they were successful in introducing capitalist relations of production - rather than just the market relations of exchange characteristic of earlier commercial activity - into certain sectors of the agriculture and primary industrial processing of the region (mainly silk and cotton). This local capitalism was always dependent on (and less profitable than) the major industrial processing of its products in Europe, and thus on the European capitalist ruling classes. Its position was, further, dependent on the general domination of the region by European imperial interests and the capitalist world-market: it was this that ensured it could overcome the older ruling classes, or was permitted to prosper by them as they 'adapted' to the new conditions. But we can nonetheless speak both of a local Arab-Ottoman capitalist class, with interests in agriculture and industry as well as trade and finance - more than a merely commercial 'comprador' bourgeoisie - and of an associated 'reforming' official stratum committed to conditions favourable to capitalism.

This class and stratum were in a complex, indeed a contradictory position. Whatever local domination they possessed (as for instance over Beirut and the Mountain), and their aspirations, if they had any, to dominate Arab-Ottoman society as a whole, must be seen as critically dependent upon their affiliation with the ruling class of the wider capitalist 'worldsystem' - i.e. the imperialist bourgeoisies of Europe. It was only this affiliation, and the incorporation of the Arab-Ottoman lands into the capitalist world-system, that had 'promoted' them from subordinate groups of merchant capitalists or officials to the status of an actual or potential ruling class. But on the other hand, their local domination was quite 
real, though limited; and their aspirations to wider power or influence - within a particular historical period - fairly plausible. And they had a distinct interest in preventing themselves from being supplanted outright by Europeans, or reduced emphatically to the status of servants. So that such a class or complex of class and official stratum, although operating within very strict limits, need not be finally dismissed as a mere 'comprador' bourgeoisie, subservient to colonial masters, or a collaborationist 'feudal' elite.

It was this class - or better, perhaps, classes, or 'new social groups' - which was the principal force behind the cultural movement that became known as the 'Nahda', at least until the final quarter of the century. The 'Nahda' may be regarded in this period as in large part the 'expression' of this class, its interests and aspirations, and its interactions with other social groups and forces in the region. The 'Nahda' bears, of course, the marks of these forces - Western, Ottoman, missionary - as well as of the older, 'traditional' social groups, now engaged in an operation of mutual 'adaptation' with the new capitalist and bureaucraticlandowning classes; we can see many features of it as forms of these adaptations and exchanges. It was also in some sense the product of 'intellectuals', but it is hard to see these, in this period, as forming a distinct group or interest, an 'intelligentsia' distinct from the bourgeois and bureaucratic classes. This changes somewhat in the final quarter of the century, outside our period proper, when it is possible to see a distinct 'petit-bourgeois' or professional stratum splitting off from the bigger bourgeois and landowner-bureaucrats, in what 'Āmil called a process of 'class differentiation'. It was this stratum which then formed the basis for the political 'radicalism' or 'utopian socialism' of the turn of the twentieth century, as described by Ilham Khuri-Makdisi, and which was itself a new turn in the evolution of the 'Nahda'. There are precursors of this later development within our period, certainly (Marrāsh being one of the most interesting), but the predominant tone of the Nahda 
remained, through the middle decades of the century, in tune with the interests of these rising classes. 


\section{Chapter 2}

\section{The Discourse of Civilisation}

Most of the inhabitants of Beirut are civilised; all their sympathies are directed towards civilisation and incline to it.

Buțus al-Bustān̄̄, 1869

Our first chapter has considered the cultural movement of the Nahda - or its distinct component formations, in Bilād al-Shām and Egypt - from a largely external point of view, in an attempt to 'place' it socially and historically. The remainder of this study will consider it to a far greater extent from an 'internal' aspect, by way of detailed examination of some of the movement's actual intellectual and creative production.

In the central period of this study - from the late 1840 s to the early 1870 s - it is above all Beirut which appears as the leading centre of the Nahda. This is not to disparage the contributions of Egypt, Tunis, or Istanbul, of other Syrian cities, or of the European capitals of the diaspora. But the initiative, in terms of cultural production, which had been held in the 1830s and 40s, probably, by the translation and printing enterprise in Egypt, can be seen to have shifted, during these crucial middle decades of the nineteenth century, decisively to Beirut, before shifting back to Cairo and Alexandria, largely through the agency of Syrian intellectuals, from the late 1870 s onwards. It was Beirut, through the middle decades of the century, that saw the founding of the Syrian Society for Arts and Sciences in 1847; the Arab League for the Publication of Arab Books in 1860; the Syrian Press in 1858; Bustān̄̄'s Madrasa Wațaniyya (National School) in 1863; and of the most important of the early newspapers: Hadīqat al-Akhbār in 1858, al-Jinān in 1870, Thamarāt al-Funūn in 1875, and 
al-Muqtataf in $1876 .{ }^{238}$ We have already examined the peculiar circumstances that allowed Beirut, at just this time, to become a centre for the emerging bourgeoisie and its cultural as well as other institutions: the new city with its absence of vested 'notable' interests; the mushrooming of trade with Europe; the combination of reasserted Ottoman control and European diplomatic pressure; the presence of foreign merchants and missionaries; the subduing of the Mountain shaykhs after 1861 and the implementation of a capitalistic legal regime.

We must now turn our attention to the remarkable cultural movement which these external conditions permitted and encouraged - before looking in turn, in Chapters 3 and 4, at a prelude to the Beirut of the 1840s-70s, in Țahțāwī and the earlier Egyptian translation movement; and at one of its consequences and analogues, in the Aleppo Circle and the utopian narrative of Fransīs Marrāsh. I will concentrate here on one particular aspect of the Beiruti 'formation', which seems to me probably the most crucial contribution of the Beiruti intellectuals in these decades. This is the discourse and vocabulary of the Nahda, centred around the concept of 'civilisation', which may be seen as growing to maturity in this time and place - in conjunction with the literary forms in which it was expressed.

This changing 'vocabulary' or 'discourse', or some aspects of it, have attracted attention in the past: the 'discourse (khițāb) of the Nahda' is analysed in a useful essay by Māhir alSharif,${ }^{239}$ while the complex of ideas which the vocabulary dealt with were, of course, the subject of Hourani's Arabic Thought in the Liberal Age. There are several detailed studies of Arabic political terminology in the nineteenth century, from Leon Zolondek's articles of the 1960s to Lewis's Political Language of Islam, and the solider work of Helga Rebhan and

238 For a general history of the press, see Ayalon, The Press in the Arab Middle East, especially Chapter 2, 'Enthusiastic Beginnings: The Private Press, 1855-1882'.

239 'Qirā'a fì khitāa 'așr al-nahḍa', in 'Sharīf, Rihānāt al-Nahḍa, 36-86. 
Ami Ayalon. ${ }^{240}$ But these are confined to political vocabulary, and deal only incidentally with the wider social and cultural sphere; other studies are specialised in other areas, scientific terminology for instance, or focussed on specific linguistic problems of word-coinage and the like. ${ }^{241}$ All, meanwhile, are hampered by the absence of a historical dictionary or serviceable corpus of nineteenth-century Arabic; largely for this reason they are materials for a systematic study of 'keywords' of the Nahda, ${ }^{242}$ rather than being that study in themselves. Nor do studies of this type generally try to integrate the study of a vocabulary with that of the concepts that vocabulary expresses, the related literary forms, and the pressures and constraints of a wider social history - which is the ambition of Raymond Williams's cultural materialist approach to the study of a cultural 'formation'.

I do not claim to have lived up to this ambition in the present chapter - the most I can hope to do here is to gesture towards such a holistic study of the Nahda as 'formation'. What is offered here is something closer to Williams's early work, in Culture and Society: the study of a pattern of ideas and its vocabulary, through the examples of particular authors and their writings. ${ }^{243}$ The focus in this chapter is above all on a particular moment - the crisis of 186061 - and a particular response - that of Buțus al-Bustānī, in Nafìr Sūriyya. This is treated as the moment of decisive crystallisation of the complex of terms, concepts and literary forms which amount to the 'discourse' of the Nahda. The later consolidation of these developments

240 Leon Zolondek, 'Al-Tahtawi And Political Freedom', The Muslim World 54, no. 2 (1964): 90-97; ‘AshSha 'b in Arabic Political Literature of the 19th Century', Die Welt Des Islams 10, no. 1 (1965): 1-16; 'The French Revolution in Arabic Literature of the Nineteenth Century', Muslim World 57, no. 3 (1967); Bernard Lewis, The Political Language of Islam (Chicago ; London: University of Chicago Press, 1988); Helga Rebhan, Geschichte und Funktion einiger politischer Termini im Arabischen des 19. Jahrhunderts, 1798-1882 (Wiesbaden: Harrassowitz, 1986); Ami Ayalon, Language and Change in the Arab Middle East: The Evolution of Modern Arabic Political Discourse (Oxford and New York: Oxford University Press, 1987).

241 See, for instance, Mohammed Sawaie, Azmat al-Muștalah al- 'Arabī fì al-Qarn al-Tāsi' 'ashar (La Crise de La Terminologie Arabe Au XIXe Siècle. Introduction Historique Générale) (Damascus: Institut Français de Damas, 1999); İmān al-Sa 'îd Jalāl, al-Muștalah 'ind Rifā 'a al-Ṭahțāwī: bayn al-Tarjama wa-l-Ta 'rīb (Cairo: Maktabat al-Ādāb, 2006).

242 Along the lines of Williams, Keywords; or of the recent 'Early Modern Keywords' project for European languages.

243 Culture and Society 1780-1950 (London: Penguin, 1961). 
through the 1860 s, in the writings of Bustānī and others, will then be more briefly dealt with.

\section{Prologue: Khalīl al-Khūrī’s introduction to Hadīqat al-Akhbār}

First, however, and by way of prologue, it will be instructive to cast our attention back a couple of years before 1860, to see the 'discourse' in a still emergent and somewhat uncertain form. I have already cited as an example of the new spirit of a 'New Age' that was gaining ground among educated Arabic speakers the letter or address to readers which inaugurated Khalīl al-Khalīl al-Khūrī’s new journal, Hadīqat al-Akhbār, on 1 January 1858. Khūrī was then aged only twenty-one, and had already a precocious reputation as a poet and $a d \bar{l} b$; his journal, as we have seen, was the first major one in the Arab world to be privately financed, largely through the patronage of the wealthy merchant Mīkhā'îl al-Mudawwar. ${ }^{244}$ Khūrî's introductory article to the first issue is a kind of manifesto both for the newspaper itself and for the project of education and enlightenment in Syria and other Arab lands, in what is perceived as a 'new age'. These new proclamations are, however, introduced and framed within older conventions; for the article begins in scholarly or adab mode, with the conventional praise of God in terms of the subject of the document, in this case news.

We praise you, who have made our Creation in your divine wisdom; and filled with your virtue all that your eternal providence has established. And made man master over this throbbing universe; so that it expanded by his renewed works as the moments pass; and made the news of each people a tale; and made sweet the hearing

244 A useful short biography of Khalīl al-Khūrī is in Fruma Zachs, 'Building a Cultural Identity: The Case of Khalil al-Khuri', in From the Syrian Land to the States of Syria and Lebanon, ed. Thomas Philipp and Christoph Schumann (Beirut: Ergon in Kommission, 2004), 27-39; Also useful is Muhammad Sayyid 'Abd al-Tawwāb's 'study' in the facsimile edition of Khalīl al-Khūrī, Way, Idhan Lastu bi-Ifranjī: Awwal Riwāyah 'Arabiyya, Facsimile (Cairo: al-Majlis al-A ' lā li-l-thaqāfa, 2007). See also Zachs, Making of a Syrian Identity, 228-9; and for the early fiction published in Hadīqat al-Akhbār, Basiliyus Bawardi, 'First Steps in Writing Arabic Narrative Fiction: The Case of Hadīqat al-Akhbār', Die Welt Des Islams 48, no. 2 (2008): 170-95; Zachs has also dealt with other aspects of Hadīqat al-Akhbār, including advertising: 'The Beginning of Press Advertising in 19th Century Beirut: Consumption, Consumers and Meanings', in The Economy As an Issue in the Middle Eastern Press, ed. Gisela Procházka-Eisl and Martin Strohmeier (Münster: LIT Verlag, 2008), 187-202. 
of any marvel that may come, old or new. ${ }^{245}$

This then leads into a panegyric of the Ottoman state and its Sultan, 'Abd al-Majīd Khān:

And you have made for each people a warning, that the sinful may take heed, and the neglectful be awakened; and placed in each heart a zeal, that the lazy may be active, and the ignorant rightly guided; and established for each people kings to rule among them with justice and good deeds [...] And you have placed over us the throne of the Ottoman Sultanate, the tower of whose sublime Caliphate shines forth.... ${ }^{246}$

The tone changes somewhat with a section in verse. This opens:

\section{The New Age}

Arise: see how the universe orders itself by design; and witness the age, how it smiles with refinement! $!^{247}$

This sense of living in new and hopeful times comes through at its strongest in the poem's concluding lines:

So thanks are inscribed with praise in our heart, and joy engraved with affection in our face.

Our ancestors went before, in troubled ages; they passed on, never saw the world, did not know;

If they were to awaken to the generosity they would find in this time, they would think it a dream!

O lands of the East, arise from your sleep! Sciences have protection in your country; The cups of happiness are pure with justice, so drink! And this is the garden of the age, so take it! !48

245 Hadīqat al-Akhbār, 1:1 (1 January 1858). The pages are unnumbered; the epistle takes up the entire first (broadsheet) page, and the first column of the second page.

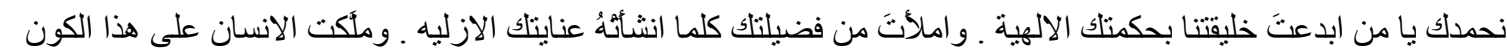

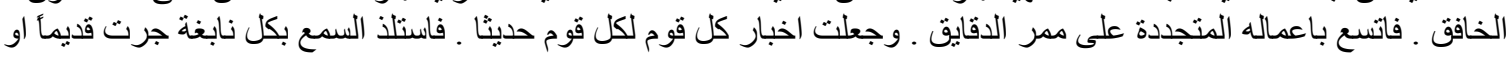

246

وجعلت في كل قوم عبرة لينتبه المخطى ويستنهض الغافل ـ ووضعت في كل قلب غيرة ليتنشط الكسلان ويسترشد الجاهل و اقمت

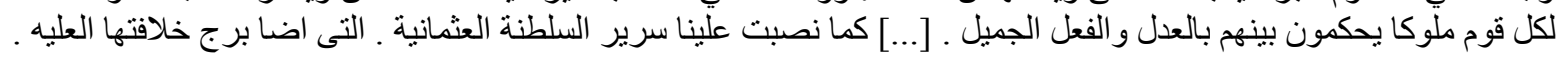

247

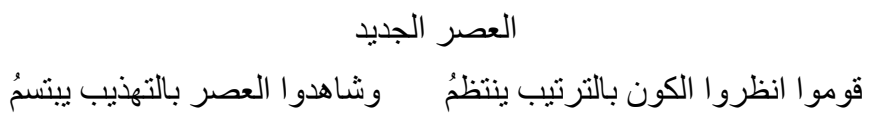

248

$$
\text { اجدادنا سلفو ا فى قلبنا بالحمد مكتتب البشر فى وجهنا بالانس مرتسم }
$$


The final hemistich is a punning advertisement for the newspaper itself (Hadīqat al-Akhbār:

the 'Garden of News'). The verse is followed by a prose section, beginning:

And raise your gaze to the horizon, calling for the perpetuation and confirmation of this Sublime [Ottoman] State. For it, wishing to spread knowledge (al-ma' $a \bar{r}$ rif) and sciences (al-funūn $)^{249}$, and desiring to advance the steps of civilisation (tamaddun) and refinement (tahdhi $b)$ in its protected lands, has spread printing-presses, which are among the greatest factors leading to the progress and success of mankind, and has published news sheets in various languages, knowing that they are the lamp of refinement (tahdhìb) in the land, which has now reached a high degree of civilisation (tamaddun), and become a centre of knowledge and sciences.... ${ }^{250}$

Khūrī goes on to praise Muhammad Khūrshīd Pasha and Musțafā 'Ārif Efendi, the

Governor-General and Defterdar of Sidon Province, of which Beirut was then the

administrative centre. He expresses his thanks to various Ottoman officials who have

assisted in setting up the newspaper: these include Sāmī Pasha, head of the Council of Public

Instruction in Istanbul, ${ }^{251}$ Sāliḥ Wāmiq Pasha, former Governor of Sidon Province and

currently Governor of the Province of the Archipelago, ${ }^{252}$ and Ibrāhīm Bey Karāma, Arabic

translator to the Sublime Porte (al-turjumān al- 'Arabì fì al-Bāb al- 'Ālì). ${ }^{253} \mathrm{He}$ then lists the

details of the paper's purposes and function, including prices. The epistle concludes with a

description of the new developments in Syria. This opens:

$$
\begin{aligned}
& \text { لو نبهو ا للذي نلقاه من كرم في ذا الزمان لظنوا انه حلم } \\
& \text { يا جيرة الشرق هبو ا من رقادكم ان العلوم لها فى قطركم ذمم } \\
& \text { راقت كووس الهنا بالعدل فارتثفو ا وذي حديقة هذا العصر فاغتنموا }
\end{aligned}
$$

249 This might also be translated by 'arts'. For an account of the various and changing meanings of the term fann, see Adam Mestyan, 'Arabic Lexicography and European Aesthetics: The Origin of Fann', Muqarnas 28 (2011): 69-100. 250

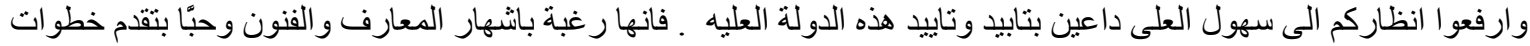

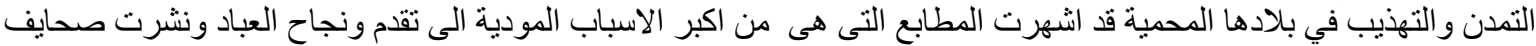

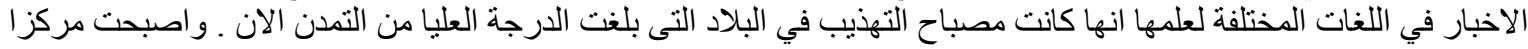
للمعارف ـ و الفنون [....

251 'Majlis al-ma ārif al- 'umūmī bi-Dār al-Salțana.' The Ottoman name was Meclis-i Maârif-i Umûmiye. 252 Jazāyir Baḥr Safĩd: also known as the Province of the Islands of the White Sea, this province included Gallipoli, many of the Aegean islands, Rhodes and Cyprus.

253 Ibrāhīm Karāma (1823-88), the son of Bashīr Shihāb II's court poet, was a well-known poet and adīb; he later worked for Fuad Pasha and joined the Council of Public Instruction. See Louis Cheikho, al-Ādāb al'Arabiyya fi al-qarn al-tāsi' 'ashar, 2nd ed. (Bayrūt: Jesuit Press, 1924), 2: 141-3. 
And here we are now, casting our gaze over the surface of the land; and we see that the people have begun to be enlightened by the lamps of refinement, giving them a taste of the delights of the new age.... ${ }^{254}$

The final paragraph again directly addresses the readers, in what amounts to a call to arms:

So it is up to you, people of the country, young men of the homeland: your minds must be stirred by cultural honour, and your bodies shaken by patriotic ardour, so that you storm forth to acquire knowledge and science $[\ldots] .{ }^{255}$

The epistle is signed by 'the director (mudīr) of Hadīqat al-Akhbār,' Khalīl al-Khūrī.

What is interesting about this epistle is that themes which were later to become characteristic of the $n a h d a$ - the new age, the homeland, 'refinement' or civilisation, the direct form of address to the readership - are still partially framed by older conventions. The first of these, the 'topical hamdala' making use of $s a j$ ', is the usual convention for opening an adab-style work of almost any kind, here operating to domesticate what is a relatively new literary form - the newspaper - by placing it within the $a d a b$ norms. Another aspect of this 'domestication' is evident in the title of the newspaper: Hadīqat al-Akhbār (Garden of News) depends on the traditional image of literary culture $(a d a b)$ as a garden. ${ }^{256}$ We can see here one aspect of the inheritance of Khūrī's generation from the literary and intellectual circles at the court of Bashīr Shihāb, and from Maronite schools such as 'Ayn Waraqa - and beyond them, doubtless, from earlier generations of literati.

The second convention which seems inherited from the past is the stress on traditional

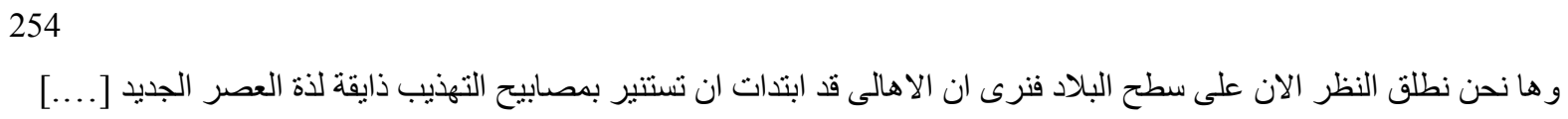

256 The same metaphor is active in journals founded later, such as the Beirut-based al-Jinān (Gardens: 1870), Thamarāt al-Funūn (Fruits of Knowledge: 1875), and al-Muqtataf (Pickings: 1876); and Ṭahțāwī's Rawdat al-Madāris (Garden of the Schools: 1870) in Cairo. See Mestyan et al., 'Project Jara'id'. 
political authority: the ruler, the praise of the 'Sublime State', the thanks to Ottoman bureaucrats. We have seen already (Chapter 1: 'Patterns of patronage') how much the very enterprise of setting up a newspaper, even a privately financed one, was bound up with state approval, as well as Khūrī's own official positions, including that of censor of the press. Here we can see official patronage inscribed in the content and form of the newspaper itself. $^{257}$

Even in this apparently 'traditional' opening section, however, there are traces of the rather different emphases to come: the sense of a world full of movement and potential, as man is described as 'master over this throbbing universe'; the works of God 'renewed' and expanding 'as the moments pass'. The mention of 'zeal', activity and awakening in this early $\operatorname{masj} \bar{u}{ }^{\prime}$ section belongs to the same language. And the association of political rule with such activity and zeal recalls the Tanzimat, which had opened up much of the space for projects such as Hadīqat al-Akhbār.

One central emphasis of the epistle comes through clearly with the verse section: the sense of living in the opening of a 'new age' or 'new times'. ${ }^{258}$ This first issue of Hadīqat al$A k h b \bar{a} r$ was also, we should note, printed on the very first day of 1858 - '1 kānūn al-thānī iftitāh sanat 1858 ' ('1 January, opening of the year 1858'), according to the paper's date-line - the opening of a new year, and of a new age. This theme would have been further reinforced had Khūrī been able to follow his original plan of naming the paper al-Fajr alMunir (The Shining Dawn). ${ }^{259}$ The suggestion that the ancestors, if revived, would not recognise this new and wonderful world, carries the sense of a decisively new period; and

257 A German traveller in 1872 referred to the 'sarcastic smile' which Khūrī's bombastic accounts of official events brought to the lips of readers: Alfred Freiherr von Kremer, 'Ein Jahr in Beirut', Das Ausland (Augsburg), 1872, 151.

$258 \mathrm{Al}$ - 'Așr al-jadīd was also the title of an 1863 poetry collection by Khūrī. 259 Mentioned in Ayalon, The Press in the Arab Middle East, 32. 
the valuation is unambiguously positive. This is accompanied by the sense of a new generation: the 'young men of the homeland' mentioned in the extract last quoted (we recall that Khalīl al-Khūrī was only twenty-one when he wrote these lines in 1858). The 'new times' are times for energy and zeal: this is a fairly early example, for Syria, of what was to become a common appeal to 'awaken from slumber'. We can make a reasonable guess as to the two main events that had given Khūrī this sense of a 'new age' dawning: the dramatic expansion of Beirut as Syria was drawn into the wider global economy, and the Ottoman Tanzimat reforms.

A second crucial emphasis is the belief in the wațan, the homeland. The Arabic translator to the imperial court, Ibrahim Bey Karamah, is praised for 'his well-known concern and love for this homeland' ('himamahu al-shahīra wa-maḥabbatahu ilā hādhā al-wațan'). The exact extent of the watan at this point is not clear, but Khūrī seems to have thought mainly in terms of Sūriyya, Syria: Hadīqat al-Akhbār, we are told, is printed by the Syrian Press (al-Mațba'a al-Sūriyya), which is 'dedicated to the service of the homeland' ('qad takhașșașat bi-khidmat al-watan'). There is also the wider concern with the Ottoman state, or, in the verse section, with the 'lands of the East' in general.

The third important element of response is the stress on the value of education, knowledge and refinement, with their institutional manifestations, printing-presses and newspapers such as Hadīqat al-Akhbār. The main general term in use for this area of meaning is tahdhīb (education or refinement: from a root suggesting 'pruning' or 'polishing'); another metaphor is that of 'enlightenment' with its attendant 'lamps'. The word later to become prominent in the sense of 'civilisation', tamaddun, is difficult to distinguish here from tahdhīb, with which it appears to be used almost interchangeably. Another term used in this connection is the 
ubiquitous adab, as in al-nakhwa al-adabiyya ('cultural honour'). We can also trace the emergence of two terms later to become prominent in connection with tamaddun: taqaddum ('advancement' or 'progress') and najāh ('success'). In the first use of taqaddum cited above ('taqaddum khațawāt al-tamaddun wa-l-tahdhīb'), the metaphor of 'steps' is still active; in the second ('taqaddum wa-najāḥ al- 'ibād'), 'taqaddum and najāḥ' are still attributes of 'mankind' (al- 'ibjad). This appears to point to the relative novelty of the terms: they cannot yet be used without qualification as the isolated abstractions al-taqaddum and al-najāh, Progress and Success.

Along with these new emphases comes a new form of expression: the direct and rousing address to the readers, in the second person plural. This can be linked both to the 'rousing and awakening' trope and to the term which, though not used in this epistle, Hadiqat al$A k h b \bar{a} r$ was soon to introduce to describe its readership: al-jumhūr, 'the public'. ${ }^{260}$ Despite the framing of the epistle in more traditional conventions - the 'topical tahmìd' and panegyric of the ruling power - the direct address and appeal to the jumhūr indicates a new, emergent type of relationship between writer and readership.

Khūrî's epistle illustrates many of what were to become the crucial terms and modes of the Nahda while they were still in the process of emergence. This epistle can thus be seen as an early and in some ways transitional example of what was later to become a settled formation based around the 'homeland' (wațan) and 'civilisation' (tamaddun).

260 According to Zachs, Hadīqat al-Akhbār was the first publication to popularise the term al-jumhūr al-Sürī for its readership, along with al-umma al-Sūriyya: Making of a Syrian Identity, 163-4. 


\section{Civilisation in the crisis of 1860}

We see a further development of this formation of words and ideas when we turn to the tracts of Buțrus al-Bustān̄̄'s Nafìr Sūriyya (The Syrian Clarion: 1860-1861), which have received considerable attention as a crucial turning-point of the Nahda. ${ }^{261}$ Bustānī's wațaniyyāt, published between September 1860 and April 1861, are in fact a new literary form, called forth specifically by that crisis. All follow a common pattern. They open with the address 'yā abnā' al-wațan', 'O sons of the homeland!' (or more succinctly, 'Countrymen!'). Here we see the framework of $a d a b$ convention dropped entirely, in favour of this striking call, consistent with the title's awakening clarion or bugle. It is Khūrī's 'qūmū unzurū' again, but with a new urgency, in response to the religious violence of $1860 .{ }^{262}$ The focus shifts between the different wataniyyāt but all return to certain common themes: the current crisis, the need for unity among the 'sons of the homeland'. They typically end on a note of religious homily (which we can perhaps relate to Bustān̄̄'s role as a lay preacher in the small Syrian Protestant community). The mood alters as the series progresses: from the improvised urgency of the first, brief wataniyya to the more measured and optimistic discussions, sustained across several lengthier wataniyyāt, of the later part of the series. In these changes the changing experience of the 1860-61 crisis itself can be traced: in September 1860, not long after the June-July period, when Beirut itself had been seriously threatened, serious violence was still going on in Mount Lebanon and the shock of the arrival of French troops was only six weeks old. ${ }^{263}$ By the spring of 1861 , the restoration of imperial rule was under

261 From George Antonius, The Arab Awakening: The Story of the Arab National Movement (Capricorn Books, 1946); to recent writers like Stephen Sheehi, 'Unpacking Modern Arab Subjectivity: Reading al-Mu'allim Butrus al-Bustani's "Nafir Suriya", The Arab Studies Journal, 1998, 87-99; Nadia Bou Ali, 'In the Hall of Mirrors: The Arab Nahda, Nationalism, and the Question of Language' (Doctoral thesis, Oxford, 2012). An English translation by Jens Hanssen is currently in press; not having seen this I have provided my own translations.

262 Cf. Stephen Sheehi's comments on the use of the second person plural to directly address the readership in Nafir Süriyya: 'Inscribing the Arab Self: Butrus al-Bustani and Paradigms of Subjective Reform', British Journal of Middle Eastern Studies 27, no. 1 (2000): 7-24.

263 See Leila Tarazi Fawaz, An Occasion for War: Civil Conflict in Lebanon and Damascus in 1860 (Berkeley: University of California Press, 1994), 75-76. 
way, and Fuad Pasha had forestalled the possibility of a lasting foreign occupation: for the

Beiruti bourgeoisie, trade and profits were not slow to revive. ${ }^{264}$ September had been a dark time, of violence, anxiety, and national shame; by April, the situation was at least stable, and the future relatively bright. ${ }^{265}$

The scope of the term wațan, from which Bustāni derived the title of the wațaniyyāt, requires examination. It is in the first place a territorial term: the land itself, unlike those terms, umma, milla, ța 'ifa and the like, which refer to a community of people (however defined). The limits of the wațan for Bustānī or Khūrī at this point are debatable. In earlier usages, the wațan had generally been a city, or a city with its attendant hinterland, ${ }^{266}$ and this usage doubtless persisted. Eight years later, in 1869, Bustānī himself would refer to Beirut in passing as 'wațanunā' ${ }^{267}$ Yet in Nafìr Süriyya he seems to have been trying to alter its usage towards a larger territory, taking in the rural areas as much as the cities. In the fourth wațaniyya he defines the wațan:

264 A British consular report for 1861 noted that the foreign trade figures were actually increased for that year on the previous one, despite the 'tragical events' of 1860: he cites as reasons the fact that ' 1859 followed a year of commercial crisis', while early 1860 had seen considerable recovery, plus that the European military forces in Beirut and the international charitable contributions 'gave an exceptional stimulus to some branches of trade.' It was largely 'the industry and trade of central Syria' - Damascus, Hasbaya, Zahle and Deir al-Qamar - which had suffered from the crisis Moore, 'Report by Mr. Acting Consul-General Moore on the Trade of Beyrout for the Year 1861.', House of Commons Parliamentary Papers 1863, no. LXX (1863): 448-9; Owen, The Middle East in the World Economy, 165 suggests that Moore's remarks on the 'surprising progress in wealth, population and general prosperity' refer to the Mountain rather than Beirut, but this seems incorrect.

265 Fawaz, An Occasion for War, 164 ff; Țarābulsī, A History of Modern Lebanon, 38-9.

$266 \mathrm{See}$, for instance, the ways in which Christian Arab writers of the early nineteenth century refer to themselves: 'Bāsīlī Fakhr ibn al-marhūm Yūsuf Fakhr al-Ūrthuduksī madhhaban al-Dimyāṭ̂̄ wațanan', 'Bāsīlī Fakhr, son of the late Yūsuf Fakhr, Orthodox by religion and Damiettan by homeland': Bāsīlī Fakhr, al-Jawāhir al-fakhriyya 'an al- 'illa al-inbithāqiyya (Jerusalem: Greek Orthodox Patriarchate Press, 1861), 7; manuscript dates from the early nineteenth century. Or: 'Īliyās ibn Faraj ibn Ḍāhir al-Ḥalabī aṣlan wanasaban * wa-l-Byzānțī mawținan wa-maqarran', 'Īliyās, son of Faraj, son of Dāhir, Aleppine by origin and lineage, and Byzantine by homeplace and residence': Īliyās al-Ḥalabī al-Byzānțī, Qiș̣at Tīlīmāk ibn Ūlīs al-Hakim (translation of Fénelon's Les avantures de Telemaque), manuscript written in Istanbul in 1812: Bibliothéque Nationale de France, MS Arabe 6243. For these writers see Hill, 'First Arabic Translations of Enlightenment Literature.'

267 'Khițāb fī al-Hay'a al-Ijtimā 'iyya wa-l-Muqābala bayna al- 'awā'id al- 'Arabiyya wa-l-Ifranjiyya', in alMu 'allim Buțrus al-Bustān̄̄ : Dirāsa wa-Wathā'iq, by Jān Dāyah (Beirut: Dār al-Fikr, 1981), 167: 'Bayrūt allatī hiyya mahall iqāmatinā wa-wațanunā’: 'Beirut, which is our place of residence and our homeplace'. The Khitāa was originally delivered to the Beirut-based Syrian Scientific Society, to the members of which the 'we' of 'our' may be taken as referring. 
For Syria, known as the land of Shām, and 'Arabistān, is our homeland, with its various plains, wastelands, coasts and mountains. ${ }^{268}$

In the eleventh and final wataniyya, he refers simply to Sūriyya, the name revived notably by

Khalīl al-Khūrī and the Maṭa'a Sūriyya and now used in the title of the Nafìr:

the sons of our nation, the people of Syria ${ }^{269}$

Yet the plurality of the earlier definition appears to indicate that it was still necessary to

define this term by reference to other, perhaps more popular names: Barr al-Shām or the

(potentially wider) 'Arabistān. ${ }^{270}$ It should also be noted that loyalty to this territorial watan

in no way implies, at this stage, dissent from the Ottoman state. ${ }^{271}$

\section{The scope of tamaddun in Nafïr Süriyya}

The major stresses of the wațaniyyāt ('patriotic discourses') which make up Nafï Süriyya

fall on bringing an end to the violence, and on unity based around the watan. Yet the concept

268 Nafìr Sūriyya 4, 25 October 1860, in Dāyah, al-Mu 'allim Butrus al-Bustānī, 121.

$$
\text { فسورية المشهورة ببر الثام وعربستان هي وطننا على اختلاف سهولها ووعور ها وسو احلها وجبالها . }
$$

269 Nafîr Sūriyya 11 ('Fī al-tamaddun'), 22 April 1861, in ibid., 161.

$$
\text { أبناء وطننا أهالي سورية }
$$

270 The latter term is ambiguous: it is probably intended by Bustānī in the sense of Ibrahim Pasha's province of Arabistan, created in 1832 to cover the area occupied by his forces and thus covering roughly the same area as Bustān̄̄'s 'Sūriyya' (this sense of Arabistan survived in the Ottoman name for its Damascus army after the Tanzimat, the Army of Arabistan). But its etymological meaning is the 'Arab' (or 'Bedouin') lands in general, and it had previously been used by the Ottomans to refer to an area 'beginning somewhere south of the Taurus Mountains and including much of what is today Syria in addition to the Arabian Peninsula'. In later nineteenth-century Ottoman usage it had come to mean the Arabian Peninsula alone. See Bruce Masters, 'Arabistan (the Arabic-Speaking Lands)', ed. Bruce Masters and Gábor Ágoston, Encyclopedia of the Ottoman Empire (New York: Facts on File, Inc., 2009), 43; More generally, see Zachs, Making of a Syrian Identity, 103-104 on smaller and larger versions of the watan; 245-251 on the name 'Syria'; and 145-148, on the ambiguities of patriotism in the late 1850s, between Syrianism and Arabism.

271 As argued many years ago, specifically in the case of Bustānī: Butrus Abu-Manneh, 'The Christians between Ottomanism and Syrian Nationalism: The Ideas of Butrus al-Bustani', International Journal of Middle East Studies 11, no. 3 (1980): 287-304; For the continuing ambiguities around Syrian nationhood, see the essays collected in Adel Beshara, The Origins of Syrian Nationhood: Histories, Pioneers and Identity (Abingdon and New York: Routledge, 2011). 
of tamaddun is deployed throughout as a standard and reference point by which the current state of Syria (particularly the violence) can be judged: the expressions tamaddun, mutamaddin ('civilised') and al- 'alam al-mutamaddin ('the civilised world') are present in most of the wațaniyyāt. The final (eleventh) wațaniyya then takes up tamaddun, to define and expound it. This amounts to one of the major statements about tamaddun from this period. The wațaniyya, entitled 'Fī al-tamaddun' ('On civilisation'), opens:

\section{Countrymen!}

We have had occasion to mention civilisation many times in our previous broadsheets; and since this subject occupies the thoughts of the public (afkār aljumhür) in this generation a great deal; and since the spirit of the age is strongly inclined to seek [civilisation] and strive to attain it and to reap the fruits of its benefits; and since many people are in danger of falling into error concerning civilisation, by putting false, imitative, counterfeit civilisation in the place of true civilisation.... ${ }^{272}$

As in Khalīl al-Khūrī's epistle, the reference is to a particular generation, to the new age and its 'spirit'; to the 'public', in that recently popularised term, jumhūr. Bustān̄̄, moving from the urgent public address of the opening to a more didactic tone, now offers a definition of tamaddun:

Now, "civilisation" (tamaddun) is taken originally from the word "city." This is either in view of the fact that [the city] is the location of settlement ( 'umrān), and to distinguish [the city] from the desert ( $\left.b \bar{a} d i^{\prime} a\right)$; so that by [civilisation] is meant the way of life of settled people, as opposed to that of nomads, who have no civilisation. Or it is in view of the opposition between [the city] and the village, so that [civilisation] means the elegance (rafähiyya) of the way of life and the organization of houses and such things, which [are limited to] the people of cities (this is incorrect, as [civilisation] is present among agriculturalists and inhabitants of villages). And from there [its meaning] was expanded, and it came to refer to the meaning in which it is now understood: inner and outer refinement (tahdhīb), and adornment with knowledge, literary culture [or arts, or morals: $\bar{a} d \bar{a} b]$, and virtues (fad̄ayil). ${ }^{273}$

272 Nafìr Sūriyya 11, in Dāyah, al-Mu 'allim Buṭrus al-Bustānī, 155.

$$
\begin{aligned}
& \text { با أبناء الوطن }
\end{aligned}
$$

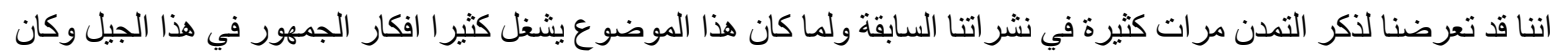

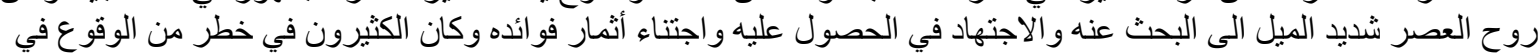

$$
\begin{aligned}
& \text { الغلط من جهة التمدن فينزلون التمدن الكاذب التقليدي المزور منزلة التمدن الحقيقي [....] }
\end{aligned}
$$

$273 \mathrm{Ibid}, 155-156$. The phrase 'mimma $\bar{a}$ la yusallam...' is unclear in the original Arabic, possibly due to a typographical error (not just an error of Dāyah's edition, however: I have checked the original broadsheets of Nafir Süriyya in the AUB Library, which contain the same wording). My translation gives what I think is the probable intended meaning. 
The etymology is followed from the traditional opposition between nomadic and settled life (bādi' $a$ and haḍr) through a further nuance between cities and rural but settled villages perhaps more relevant to nineteenth-century Syria and especially Mount Lebanon, with its rural centres of 'civilisation' such as Zahleh and Dayr al-Qamar. These older senses are then distinguished from 'the meaning in which it is now understood. ${ }^{, 274}$ What area of meaning this covers remains, at this stage, uncertain. The first reference (as with al-Khūrī) is to tahdhīb (education or refinement); after this come knowledge and $\bar{a} d \bar{a} b$ (the sense of 'polite or literary culture' appears to be the primary meaning of the term here). This area corresponds to what we can call in English 'culture' in the narrower sense: 'high' culture. But $\bar{a} d \bar{a} b$ can also be taken to refer beyond this to 'manners' and 'morals' in a more general sense, as can the imprecise fad̄ayil ('virtues'). There is thus the possibility that tamaddun can be taken to indicate a wider area of social practice: 'culture' in the broad, general sense: manners, customs, even 'a whole way of life'. ${ }^{275}$

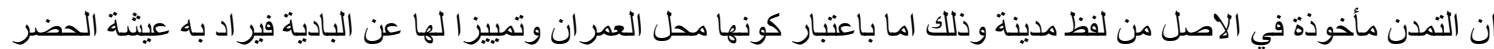

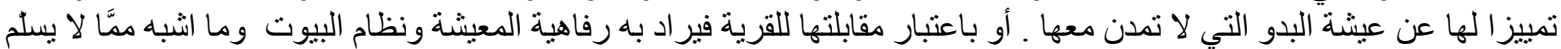

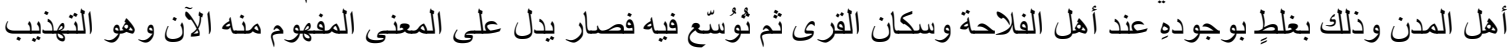

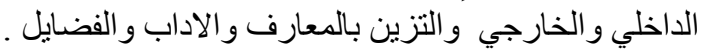

274 I have no space here to deal with the question of when these different senses of 'tamaddun' came into use. But Bustān̄̄s second set of meanings (refinement, etc) may have an older pedigree than has been assumed by Bou Ali, 'Hall of Mirrors', 194 n. 411. She suggests that Fayrūzābādī's Qāmūs, the model for Bustānī's Muhit al-muhit, contained only senses of tamaddun 'pertaining to madina, a city in general, and the specific city of the Prophet', and not Bustānī's 'man tamaddana [became civilised] by evolving from the state of barbarism and ignorance to the state of knowledge and sociability [uns]'. Yet we do find in Fayrūzābādī 'tamadyana' (assumed to be a variant form of tamaddana) glossed as 'tana 'ama' ('to become refined, polished').' See Majd al-Dīn Muḥammad b. Ya 'qūb al-Fayrūzābādī, al-Qāmūs al-Muḥịt, ed. Muhammad Na '̄imm al- 'Arqasūsī, 8th ed. (Beirut: Mu'assasat al-Risāla, 2005), 1234.

275 As is clear from this analysis, English terms such as 'culture' and 'civilisation' carry a similar ambiguity; this has been examined in detail by Williams, Culture and Society 1780-1950; 'civilisation' and 'Culture' in Keywords, 57-60, 87-93. The Arabic tamaddun had a further very interesting area of meaning, referencing the 'political' via the etymological links with madīna (town) and the Greek polis. In Bāsīlī Fakhr's translation of Les aventures de Télémaque (Damietta, 1815), the French 'police' (as in 'la police d'une ville') is translated, via Italian polizia, as tamaddun (see Bibliothèque orientale, MS no. 1512: 301). Ami Ayalon has noted (Ayalon, The Press in the Arab Middle East, 127) that the original by-line of Hadiqat al$A k h b \bar{a} r$ referred to it as a 'jurnāl madan̄̄'. He offers 'civilian' as a translation, in contradistinction to 'political' (siyāsi $\bar{l}$ ), as siyāsa was the sphere of the ruler, on which Khūrī did not presume to encroach. We may suggest a slightly different reading: given that the original by-line ('jurnāl madanī 'ilmī matjarī tārīkhī') later became 'jurnāl siyāsī adabī matjarī', it seems possible that madan̄̄ was effectively later replaced by siyāsī: i.e. it was in fact intended to mean something like our modern English 'political,' something broader sense than simply 'statecraft,' the generally cited older sense of siyāsa. 
Bustān̄̄ next makes a sharp distinction between civilised and uncivilised man:

It is no secret that man may be in this world in one of two states: the state of wildness (tawa "ur) or savagery (tawahhush), and the state of civilisation (tamaddun) or elegance (zurf). The state of wildness is the natural state in which man is created; if he were to stay in it, there would be no great difference between him and the dumb animals.... ${ }^{276}$

He also makes another crucial distinction between true and false civilisation:

civilisation has two sorts: an outward, false one which consists in some external virtues, defects and customs, [which are] borrowed and imitated, and do not proceed from original, true, established principles. The possessor of this civilisation is like a drum of great size and loud noise, but which is empty within.... ${ }^{277}$

True tamaddun, on the other hand, comes from within. In one sense this can mean from within the society in question, rather than being simply imitated from another society, such as Europe: the blind imitation of Europe is the ‘false civilisation' which Bustānī principally warns against (as we shall see later). But 'from within' also means from within the individual, the 'inner man'. As with the sharp division between civilised and uncivilised, his mode of thought here bears an affinity to the Puritan distinction between outward and inner faith, familiar from The Pilgrim's Progress, which Bustānī had retranslated in 1844; the loud drum, which is empty within, recalls the 'sounding brass and tinkling cymbals' of a character like 'Talkative'. ${ }^{278}$

Having distinguished between true and false tamaddun, he defines true tamaddun:

As for true civilisation, it is that state of the social body (hay'a ijtima 'iyya) which is

276 Nafìr Sūriyya 11, in Dāyah, al-Mu 'allim Butrus al-Bustān̄̄, 156.

و لا يخفى ان الانسان يكون قي هذا العالم في احدى حالتين حالة التو عر أو التوحس وحالة التمدن أو الظرف فحالة التوعر هي الحالة

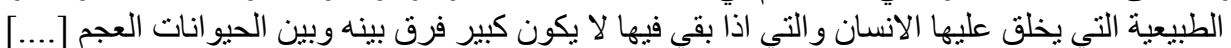

277 Ibid, 157.

و التمدن منه ظاهري كاذب يقوم ببعض مز ايا وخلال و عادات خارجية مقتبسة تقليدية غير ناتجة عن مبادى اصع اصلية حقيقية راهنة

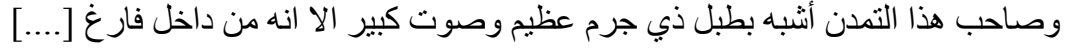

278 John Bunyan, Siyāḥat al-Masīḥ̄ (The Pilgrim’s Progress), trans. Buṭus al-Bustānī (Beirut: American Press, 1844), 160; John Bunyan, The Pilgrim's Progress (London, n. d.), 80. See Hill, 'Early Arabic Translations'. 
conducive to the growth of all the forces of the human race, individually and as a whole; therefore, it is not limited to a single thing or partial things which are found among the public (jumhür), such as sciences ( 'ulüm) and industries (sana' 'i '), for instance; rather, it extends to all the conditions of the public, organized in a social body under specific bonds, in various aspects, beginning in the inner man and from there to the outer man; and its fundamental purpose is simply growth [...]. ${ }^{279}$

civilisation must extend across the whole of the hay'a ijtimā 'iyya or the jumhūr, then: a general condition, not a particular aspect or area of the society. The programmatic nature of this initial definition suggests that it is modelled on another source, most probably European. It seems to extend the suggestion, latent in the earlier definition, that tamaddun extended beyond the realm of $\operatorname{tahdh} \bar{\imath} b$ ('refinement') or 'high culture' to the society as a whole. Nor are its ends merely individual, even if it begins with the 'inner man':

For man's success does not consist of gathering together good things, whatever they may be, and appropriating them for himself; rather, it consists of the extension of his forces, their growth, and their use in suitable matters, according to their original constitution. Because man was not created in the form of a sponge, to suck up all that he could of the wealth and the good things of the earth; rather, he was created in the image of a tree, growing and fruitful. ${ }^{280}$

Bustānī concludes with the same favourite verse he quotes at the end of his introduction to his translation of Robinson Crusoe, al-Tuhfa al-Bustāniyya:

Every person who is no good to others, I care not whether he is lost or exists. ${ }^{281}$

279 Nafìr Sūriyya 11, in Dāyah, al-Mu 'allim Butrus al-Bustān̄̄, 157.

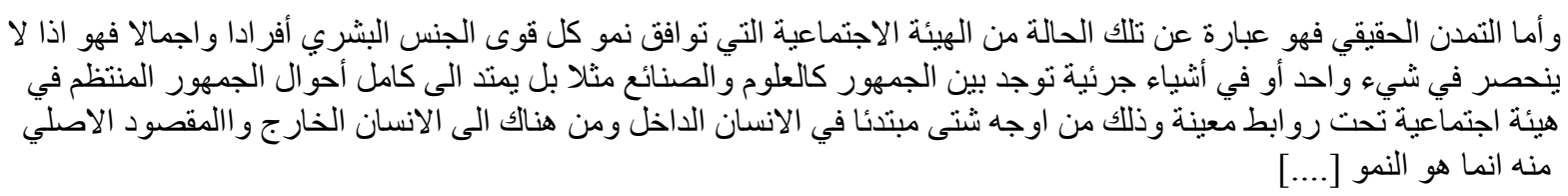

280 Ibid

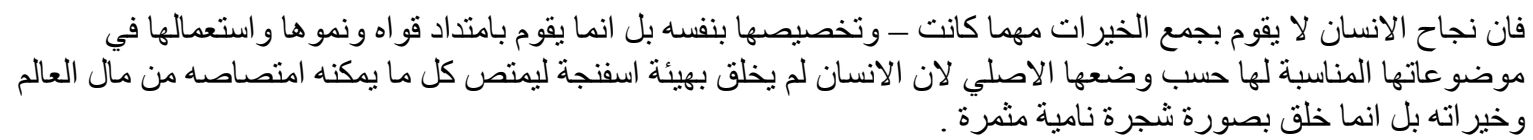

281 Ibid.

$$
\text { وكل امرء لا خبر فيه لغيره فسيان عندي فقده ووجوده }
$$

Also cited in Bustānī, al-Tuhfa al-Bustāniyya, 'Muqaddimat al-mutarjim' (no page number), with the first hemistich reading: وكلٌ امرٍٍ لا نفعَ فيِِِ لغيره. 
The scope of tamaddun as used thus extends from the individual to far wider purposes, ${ }^{282}$ and from the association with tahdhīb - a particular area of the society - to the society as a whole. The process of building self-motivated individual effort into a wider, collective project is indicated here, as in Bustān̄̄ss translations. ${ }^{283}$

We can relate this sense of tamaddun as general to a continuing argument of Bustānī, in Nafìr Süriyya and elsewhere, in favour of the common interest (al-ṣalih al- 'umūmì) as opposed to particular or sectarian interests. ${ }^{284}$ This also relates to another main trope of Nafïr Süriyya, in which the general material prosperity ( $i m \bar{a} r$ ) of Syria is seen as threatened with ruin (kharāb) due to the sectarian violence. Tamaddun provides Bustānī with another way of articulating a sense of the general interest, the common good, and of arguing against narrow and particular interests, and the ruin they may lead to. Yet its connotations remain rather distinct from those of terms such as 'imār ('prosperity', but carrying with it the sense of 'building' and physical infrastructure), al-șāliḥ al- 'umūmì ('the common interest'), or the najāh ('success') of a country. These indicate ordinary material prosperity and infrastructure, the shared material interests of the homeland; tamaddun depends on these things and perhaps includes them, yet it is not quite the same thing: it carries with it a sense of higher judgement, of an ideal standard.

\section{Tamaddun for whom?}

Bustānī goes on to expand on the element of the definition 'individually and as a whole':

282 See also Bou Ali, 'Hall of Mirrors', 149 for comments on this verse; and Hill, 'Early Arabic Translations'. 283 See Hill, 'Early Arabic Translations', especially the section 'Diligence and destiny: individual effort within a national project.'

284 Bustānī returns to this theme towards the end of the wațaniyya 'Fī al-tamaddun': Nafìr Sūriyya 11, in Dāyah, al-Mu'allim Buṭrus al-Bustān̄i, 161. 
'Individually and as a whole': from this two things are inferred: firstly, that true civilisation does not attempt to raise up a people except by raising up its individual members one by one, both men and women. Secondly, that it does not regard one group of the public over another, but regards the whole in the same manner. ${ }^{285}$

As a general condition, then, tamaddun must be available to all alike: he is at pains to include each individual, and women as well as men (elsewhere he even states that 'On their [women's] civilisation [...] depends the civilisation and success of the people'). ${ }^{286}$ Nor should one group of the public be privileged over another. This universal language accords with the terms of liberal citizenship which Bustānī lays out elsewhere in Nafìr Süriyya, and with his calls for the 'general interest' of the homeland to transcend private and sectarian interests. ${ }^{287}$ Ussama Makdisi has argued that this aspect of Bustānī’s discourse went far beyond anything emanating from the Ottoman government, in two areas: its call for the separation of religion and politics, and its insistence on an active citizenship rather than passive imperial subjects. ${ }^{288}$ The first we may perhaps grant, with the caveat that Ottoman reformers were also moving in this direction; but the second requires more examination. Makdisi claims that '[c]itizenship, for Bustān̄i, was an active process that required and demanded the participation and knowledge of all citizens,' and that in Nafìr Sūriyya Bustānī 'imagined a community of equal citizens. ${ }^{289}$ We must examine how this implied equality accords with the very different attitudes and vocabularies we also find - as Makdisi 285 Ibid, 158.

$$
\begin{aligned}
& \text { وقولنا أفر ادا واجمالا يستفد منه أمران أحدهما ان التمدن الحقيقي لا يحاول رفع شعب الا برفع أفر اده واحدا فو احدا من الرجال }
\end{aligned}
$$

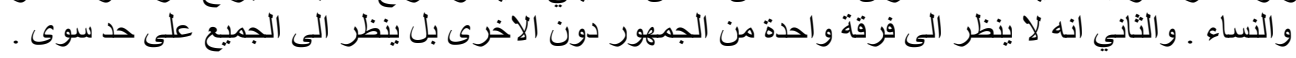

286 “Alā tamaddunihinna [...] yatawaqqaf tamaddun wa-najāḥ al-ahālī’: Nafìr Sūriyya 9 ('Arbāḥ al-waṭan aladabiyya'), 14 January 1861, in Dāyah, al-Mu 'allim Buṭrus al-Bustān̄̄, 145. Bustān̄̄ was of course an active partisan of female education; his recommendations are set out in his 'Khitāa fī Ta līm al-Nisā', in Dāyah, al-Mu 'allim Buṭus al-Bustānī. On the views of Bustān̄’s and succeeding generations on the 'women question', see Zachs and Halevi, 'Difā' al-Nisā' to Mas'alat al-Nisā' '; Marilyn Booth, May Her Likes Be Multiplied: Biography and Gender Politics in Egypt (Berkeley and Los Angeles: University of California Press, 2001); and idem, "She Herself Was the Ultimate Rule": Arabic Biographies of Missionary Teachers and Their Pupils', Islam and Christian-Muslim Relations 13, no. 4 (2002): 427-48.

287 See especially the passage on the rights and duties of the 'sons of the homeland': Nafìr Süriyya 4, in Dāyah, al-Mu'allim Buțrus al-Bustān̄i, 121-122; and his proposals for reform after 1860: Nafìr Sūriyya 10 ('Tābi' arbāḥ al-wațan al-adabiyya'), 22 February 1861, in ibid., 150-154.

288 'After 1860: Debating Religion, Reform, and Nationalism in the Ottoman Empire', International Journal of Middle East Studies 34, no. 4 (2002): esp. 606-608.

289 Ibid., 608. 
recognises - in the wataniyy $\overline{a t} .^{290}$

Certainly the final phrase of the passage last quoted - 'in the same manner' - seems to imply that all members of the society are equal in the eyes of tamaddun. But the reference to 'groups' of the public, in the context of Nafir Süriyya, refers largely to 'equality between religious communities' which were to remain under the leadership of their elites, rather than the 'equality within religious communities' which was claimed (as Makdisi has argued) by the leader of the Kisrawan rebellion, Tanyūs Shāhīn. ${ }^{291}$ Bustānī’s attitude certainly seeks to transcend sectarianism in the name of a greater 'general interest,' and calls for action on the part of Syrians, rather than simply the Ottoman state. But those who Bustānī actually calls to action in Nafir Süriyya are often the leaders of the people - as here, by Biblical allusion:

Awake, awake: why are you asleep and unaware, o shepherds of Israel and leaders of the people! ${ }^{292}$

The 'compatriots' (abnā' al-wațan) or 'countrymen' (ahāli al-bilād), so strikingly and directly addressed at the opening of each wațaniyya, thus often metamorphose into their 'leaders' or 'shepherds.' These leaders are the objects of Bustānī's exhortation and blame as well as of his hopes. Elsewhere, he writes that one of the benefits that have arisen Providentially or by chance - from the violence in Syria, is

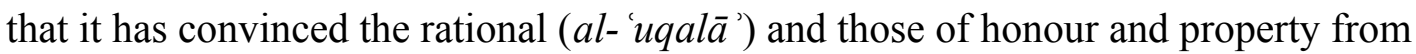
among the sons of the homeland that the blame, the loss, and the responsibility for

\section{Ibid.}

291 Makdisi, 'Corrupting the Sublime Sultanate', quotation on p. 196. We should note that Shāhīn's demand for equality was restricted to equality within the Christian community; his attitude towards other communities such as the Druze was hostile. See also Makdisi's more extended treatment of sectarianism in this period: Culture of Sectarianism.

292 Bustān̄̄, Nafìr Sūriyya 6 ('Khasāyir al-wațan wa-arbāḥuhu'), 8 November 1860, in Dāyah, al-Mu 'allim Buțrus al-Bustānī, 132.

$$
\text { استيقظو ا استيقظو الماذا أنتم نايمون ومتغافلون يار رعاة اسر ائيل وقادة الشعب . }
$$

Makdisi describes Bustān̄̄ss appeal in this passage as being to his 'compatriots' (abnā' al-wațan): 'After 1860,' 604-605. As the full citation makes clear, like other instances in Nafir Süriyya it in fact appeals to the leaders of the people. 
such deeds is in the final analysis theirs. In consequence, they can see that one of their most important interests is striving [...] to curb the ignorant, and to teach them, by example and exhortation, the effect of peace, of social affection and of love upon their opposites; and to stay within their limits, and avoid the sources [of those opposites] as far as possible. ${ }^{293}$

The reason why the elite is ultimately responsible is explained:

What are the commoners (al- 'ammiyya) capable of doing? Among their best-known characteristics is that they are blind unless there is someone to supply them with money, organization and weapons. What is to be demanded, then, from peoples $(a q w \bar{a} m)$ who are no more than a silent tool in the hand of their leaders ( $\left.\bar{u} l i y \bar{a}^{\prime} u m \bar{u} r\right)$ and notables ( $a y \bar{a} n)$, whom they follow even in that which is against their interests (if we admit that they know what their own interests are)? ${ }^{294}$

In passages such as this Bustānī appears to be writing largely for 'leaders' or 'notables'. The commoners - the remainder of the people - are a 'silent tool', incapable of independent action and knowledge of their own interests; they do not even deserve blame. The immediate point is a humane one: Bustānī is recommending the punishment of only the ringleaders of the sectarian violence. ${ }^{295}$ But in many respects, as Makdisi points out, he is moving here into the language and attitudes of the traditional 'politics of notables,' as outlined by Albert Hourani. ${ }^{296}$ There is a considerable tension between the universalizing language of liberalism, suggesting that all citizens are able to participate in such processes as tamaddun, and this older vocabulary, which suggests that participation is open only to the 'rational and those of honour and property'. The wide and universal jumhūr or hay'a ijtimā 'iyya Bustān̄̄ addresses, and which should be capable of becoming civilised, is thus in practical terms

293 Nafìr Sūriyya 9, in Dāyah, al-Mu 'allim Butrus al-Bustān̄i, 147.

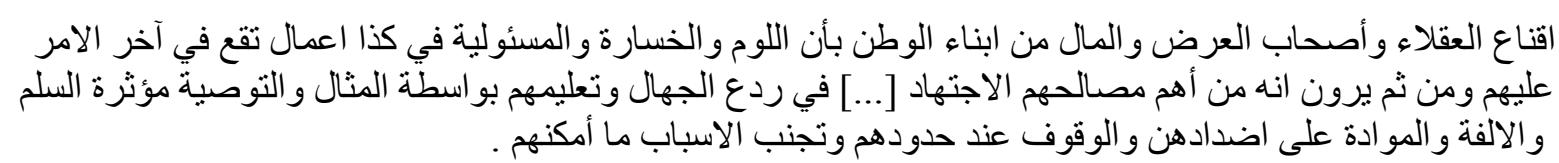

294 Ibid.

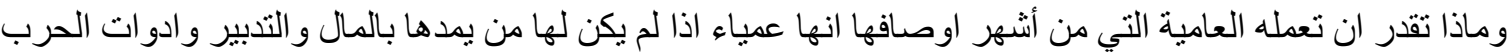

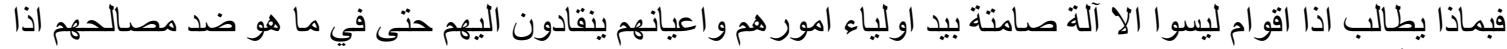

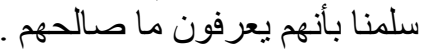

295 Nafì Sūriyya 7 ('Khasāyir al-wațan al-adabiyya'), in ibid, 133.

296 Hourani, 'Ottoman Reform and the Politics of Notables'; see also Makdisi, 'Corrupting the Sublime Sultanate', 183-184 and passim. 
limited to its leaders, one of whose duties, as we have seen, is to curb ( $\mathrm{rad}$ ) the ignorant.

Those qualified in this way, rather than the $a h \bar{a} l \bar{l}$ as a whole (and certainly not the 'ignorant' or the 'men of blood'), are called upon to be agents.

This applies, by implication, to tamaddun as well as to other aspects of politics. Towards the end of the eleventh wataniyya 'Fì al-tamaddun', he writes that one of the essential things that must exist in Syria if there is to be civilisation, is

social affection between the individuals and groups, particularly civil affection; and the presence or absence of this depends upon the powers, activity and will of the leaders ( $\bar{u} l i y \bar{a}$ 'al-umūr) far more than it depends upon the varied desires and inclinations of the people $($ ahāli $){ }^{297}$

The 'leaders' ( $\bar{u} l i y \bar{a}$ ' al-umūr: literally, those who possess the power to command) are a potentially unifying and thus, by implication, a civilizing force. The remainder of the people (ahāli) have no such unity or strength, but only 'varied desires and inclinations'. If tamaddun is ever to be universal, as previously implied (tamaddun extending across the entire social organism), the way to this, in Syria in 1861, can only lie through an elite-based politics. ${ }^{298}$

The ambiguity of Bustān̄’s position is seen not only in his discussion of the role of the local elite, but also when he considers the role of the state in spreading tamaddun. Bustānī's closeness to the aims and modes of thinking of state officials is most evident in the second wațaniyya, which is written in response (and welcome) to the Sultan's appointment of Fuad

297 Nafìr Sūriyya 11, in Dāyah, al-Mu'allim Buṭrus al-Bustānī, 161.

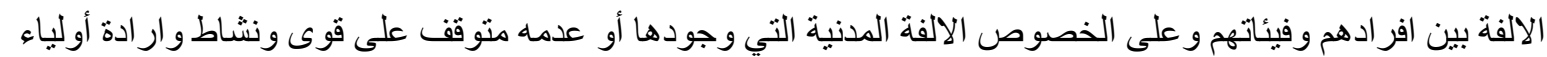

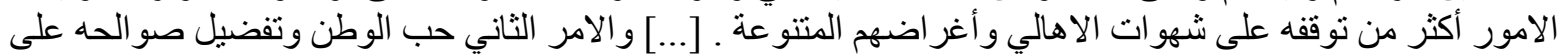
الصو الح الذاتية سواء كانت شخصية أم طُائفية .

298 One example of the way in which notables, under the 'old regime' in the Mountain, could act to defuse tensions among commoners, is found in Wheeler N. Jr. Thackston, Murder, Mayhem, Pillage, and Plunder: The History of the Lebanon in the 18th and 19th Centuries by Mikhayil Mishaqa (1800-1873) (Albany, NY: SUNY Press, 1988), 43-5. It is Makdisi's contention, in Culture of Sectarianism, that 1860 marked the replacement of this order based on rank, with a new, sectarian order (in Mount Lebanon at least), in which politics was still elite-led but the elites were beholden to their different, and now sectbased, constituencies. 
Pasha as special envoy to Syria and the accompanying imperial firmān of July $1860 .{ }^{299}$

Unsurprisingly, the state is accorded an important role by Bustānī in spreading civilisation.

One of the 'means to civilisation' he defines in the eleventh wataniyya (along with religion, and cultural institutions such as newspapers and schools) is political rule:

Secondly, political rule (al-hukm al-siyāsi). We do not mean by this any rule whatsoever, but that rule which is concerned with the good of its subjects ( $\left.r a^{\prime} \bar{a} y \bar{a}\right)$, their comfort, the success of their affairs and their advancement in knowledge, wealth and civilisation; so that it is a force for those things with them, and adopts strong, active measures to spread them among them. ${ }^{300}$

Government should thus be an active force for spreading tamaddun, as well as other kinds of prosperity, among its subjects ( $\left.r a^{\prime} \bar{a} y \bar{a}\right)$ : the emphasis appears to be mainly on civilisation 'from above'. However, Bustānī continues:

Anyone who perceives the strength of the relationship and connection between the government and the subjects will agree with us that it is impossible for a civilised people (sha 'b mutamaddin) to exist under an uncivilised government $(\mathrm{hukm})$, or for a civilised government to exist over an uncivilised people. ${ }^{301}$

This suggests more reciprocity between people and government; even that a people might civilize its government, as a government should civilize its people. The closeness between Bustānī (and by implication his elite readership) and the government should not necessarily be interpreted as absolute loyalty, a surrendering of all power to the state. Government is necessary, but it must be government of the right type. What European opinion considered

299 Nafìr Süriyya 2, 8 October 1860, in Dāyah, al-Mu 'allim Buțus al-Bustān̄̄, 115. Bustānī refers to the firman issued at the 'end of Dhū al-Hijja 1276' (the last day, $30^{\text {th }}$, of this month corresponds to 19 July 1860). Fuad Pasha was appointed on 8 July 1860: it was probably the firman issued on his appointment. See Fawaz, An Occasion for War, 105-106, where a section of the firman is quoted: Bustānī's language appears to echo it closely. It is also interesting that the set of Nafir Süriyya held by the American University of Beirut has the Arabic text of this firman bound in with it, and that this shows every appearance of having been printed on the same press as Bustān̄'s wațaniyyāt.

300 Nafìr Sūriyya 11, in Dāyah, al-Mu'allim Buțrus al-Bustān̄i, 161.

$$
\begin{aligned}
& \text { ثانيا الحكم السياسي و لا نعني كل حكم بل الحكم الذي يهمه صـالح ر فاياه ورفاهة احو الهم ونجاح أمور هم وتقدمه في المعارف }
\end{aligned}
$$

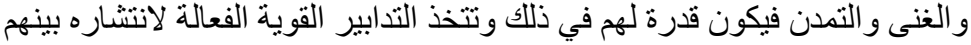

301 Ibid.

ومن لاحظ شدة العلاقة والاتصالية بين الحكومة و الر عايا يتفق معنا في الحكم بأنه لا يمكن وجود شعب متمدن تحت حكم غير متمدن ولا وجود حكم منمدن على شعب غير منمدن الأن 
relatively 'civilised' forms of government had, of course, previously been, and were then being, imposed upon Mount Lebanon by the Ottomans, at European prompting: the powersharing 'Dual Qa'im-maqamate' and the post-1860 Réglement organique. But Bustānī is determined not to back up his vision of civilised government by an appeal to foreigners, like the many Christian communities which petitioned European powers during the 1860 strife: he looks, rather, along with the Ottoman state, to his 'countrymen'. As with his suggestions in the tenth wataniyya for the good government of Syria, we can see this, with Makdisi, as a way of articulating a version of citizenship and reform somewhat different from that of Ottoman bureaucrats, and even as putting pressure on the Ottoman state, while remaining ultimately loyal to it. ${ }^{302}$ These are also, as one might expect from someone in Bustān̄̄ss position, clearly suggestions to the governors from a (loyal, if not blindly loyal) subject - as opposed to suggestions made from within the ranks of the governors themselves (See below, Chapter 4, 'The Philosopher and the King').

This ambiguity, between the older 'politics of notables' and the language of a more active and inclusive citizenship, was already implicit in Khūrī's epistle, with its blending of recognition of the Ottoman state with the new insistence on the activity and zeal of Syrian citizens (or some of them). We can see it as a manifestation of the transition from the older politics to (in Hourani's words) the era of 'the play, the novel and most of all the press-article aiming to inform, advise, criticize or arouse feeling, written not by the 'ālim responsible to an existing order regarded as of eternal value, but by the politician concerned with power or the intellectual acknowledging no sovereign except his own vision of what should or what

302 Nafìr Sūriyya 10 ('Tābi' arbāḥ al-wațan al-adabiyya'), 22 February 1861, in Dāyah, al-Mu 'allim Buṭus alBustānī, 150-154. His proposals are (briefly): strong, active government; the punishment of those fomenting civil violence; loyalty to the Sultan not the sectarian group; appointments to government positions by merit; the separation of religion and politics; and measures to guarantee public security and property. For Makdisi's comments on this, see 'After 1860', 607; See also Abu-Manneh, 'The Christians between Ottomanism and Syrian Nationalism'. 
must be. ${ }^{303}$ Men like Bustānī and Khūrī, in these years, were still in a phase of transition between these two conceptions of politics and of the role of writers and reading publics: the attraction of the emergent terms and concepts - tamaddun, the homeland, the 'new age'was strong. But, particularly in a moment of crisis such as 1860 , the old politics of notables still seemed the firmest basis for further social development: even if, as Makdisi suggests, this was itself changing into a new politics of sectarianism, and storing up troubles for the future.

\section{Tamaddun as external or internal standard?}

Tamaddun, in the abstract and universal definition given by Bustānī ('that state of the social body which is conducive to the growth of all the forces of the human race, individually and as a whole'), is principally an ideal or a standard. This is how it is deployed, in large part, in the first to the tenth wataniyyāt of Nafir Süriyya. Often this standard is clearly located outside Syria, in 'the civilised world'. This is the case in the first use of the opposition between tamaddun and tawahhush ('savagery'), in the opening of the first wataniyya:

\section{Countrymen!}

The news of the atrocities and abominations which the scoundrels among us have perpetrated this year in a short period of time has reached the ends of the inhabited earth. Its effect has been [to awaken] sorrow and pity on the one hand, and anger and fury on the other, in the entire civilised world. So that we see charity coming from all directions to aid the needy, and armies arriving from every land to protect the weak and punish the sinners and aggressors. Often we see the victorious group pride itself on what it has done, saying, "That is enough honour for us!" and the like - not knowing that the civilised world looks upon those deeds of which they boast only with disgust, contempt and anger, reckoning them to be the deeds of savage barbarians, devoid of humanity (insāniyya), good character, courage and religion; [the deeds of] thieves and highway robbers. For that reason [the civilised world] has united as one to bring down the worst punishment upon the perpetrators of

303 'Ottoman Reform and the Politics of Notables', 39. 
the outrages, and to chastise the aggressors. ${ }^{304}$

Here, clearly, tamaddun is set up as a largely external standard by which the homeland, and the primitive morality of 'victorious groups,' will be judged: the property of a 'civilised world' outside Syria. In the context of the crisis of 1860 and the international response, this meant the European powers which intervened diplomatically and militarily in Syria and also sent charitable aid to the victims. ${ }^{305}$ Bustānī wrote the words quoted above in late September 1860, six weeks after the arrival of at least one of the 'armies from every land', the French expeditionary force, in Beirut. ${ }^{306}$ The commander of this force, Marquis General Charles de Beaufort d'Hautpoul, informed his troops before departure that they were being sent by the Emperor 'in the name of civilised Europe' to 'avenge humanity'; Napoleon III himself informed them that their mission was for the sake of 'the rights of justice and humanity.' ${ }^{307}$ Fuad Pasha, dispatched by the Sultan to pacify Syria, took up the same language: according to Ussama Makdisi 'he insisted on the punishment of Druze notables whom he considered culpable for the events in Mount Lebanon, for they had, as he put it, shocked the "public conscience of the civilised world.". ${ }^{308}$ Bustānī was certainly correct in reporting that the 'civilised world' thought of itself, and its intervention in Syria, in terms of tamaddun and insāniyya.

304 Nafìr Sūriyya 1 (29 September 1860), in Dāyah, al-Mu'allim Buṭrus al-Bustān̄i, 113-114.

با أبناء الوطن

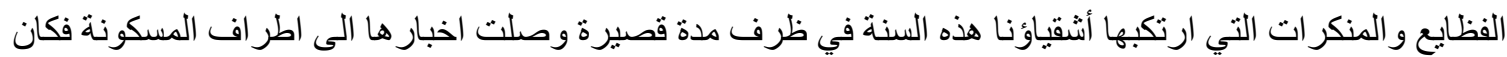

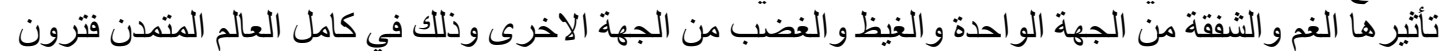

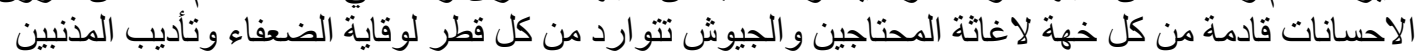

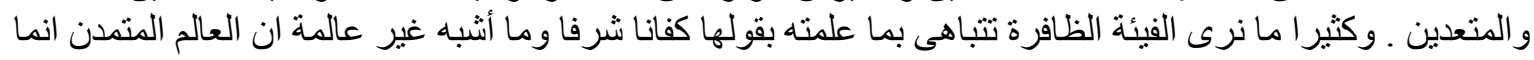

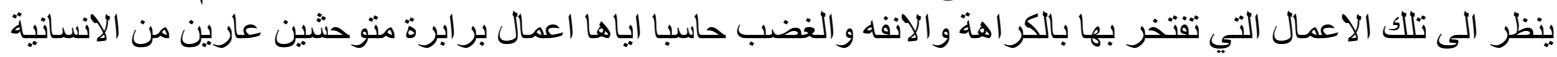

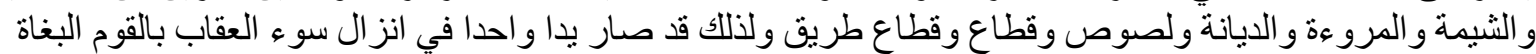

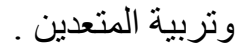

305 Bustānī refers to the charity sent: Nafìr Süriyya 6, in ibid, 130.

306 The landing of the French troops in Beirut, on on 16 August 1860, drew large crowds. The first number of Nafir Süriyya is dated 29 September 1860: by this date some of the French force was setting out into Mount Lebanon. See Fawaz, An Occasion for War, 116-118, 123-125.

307 Both addresses on 7 August 1860: cited in Fawaz, An Occasion for War, 115, 119.

308 Makdisi, 'After 1860,' 603. The citation of Fuad Pasha is from: Başbakanlık Archives, Irade Meclis-i Mahsus 935/1, Leff. 3, 24 January 1861, translated by Makdisi. 
Elsewhere in Nafìr Sūriyya Bustānī writes that one of the major 'losses' which the homeland has incurred during the recent disturbances is a loss of 'character or self-respect' (al-shima aw sharaf al-nafs), in the face of foreigners. ${ }^{309}$ Stephen Sheehi is certainly right to emphasize this 'shame' and 'embarrassment' (hayā' and khajal) before Western judgements as a vital factor in Bustān̄̄'s project in Nafìr Süriyya. ${ }^{310}$ Many of the uses of tamaddun and especially of al- 'àlam al-mutamaddin ('the civilised world') in Nafìr Süriyya reinforce the impression that tamaddun is located outside Syria, in a 'civilised world' that meant in practice the Western countries. ${ }^{311}$ Syria, in $1860-61$, is found wanting by their standards: ${ }^{312}$ one sign of this is that the 'opening of a new age for Syria', acclaimed so confidently less than three years ago by Khūrī, is now put off to the future. ${ }^{313}$ Bustānī's object often appears to be to communicate the shame he feels before Western judgements to the 'sons of the homeland', in order to shame them into putting an end to the sectarian violence.

This might, of course, lead to the call for tamaddun being read as a simple exhortation to accept the civilisational standards of the West. But it is precisely against an uncritical acceptance of all things European that Bustānī is concerned to warn in the eleventh wațaniyya. Here he stresses that by his universal definition of tamaddun, existing civilisations can be judged, and none is perfect. After commenting on the failings of the past civilisations of the Greeks, Romans and Arabs, he moves to modern Europe:

If we submit the present civilisation of Europe to the aforementioned definition [i.e.

309 Nafìr Sūriyya 8 ('Tābi ' khasāyir al-wațan al-adabiyya'), in Dāyah, al-Mu 'allim Buṭrus al-Bustānī, 137. 310 Sheehi, 'Unpacking Modern Arab Subjectivity'; 'Inscribing the Arab Self'.

311 Other Nahda writers - like Shidyāq in 1861 - had certainly showed their awareness of the Western propensity to assume that countries like Syria could not become civilised: see his article 'Fī al-tamaddun', al-Jawā'ib 6 (5 July 1861): partial translation in Bou Ali, 'Hall of Mirrors', 253-4.

312 See especially a passage of the fifth wataniyya, where Bustāni speaks of 'excus[ing] the sons of our homeland' before foreigners for their 'stupidity, lack of civilisation ( 'adam al-tamaddun) and the overcoming of the forces of reason by selfish desire (shahwat al-nafs)': Dāyah, al-Mu 'allim Butrus alBustānī, 124.

313 Nafir Sūriyya 4, in ibid, 122. 
'that state of the social body which is conducive to the growth of all the forces of the human race'], we can see that most of it is incomplete in many ways; this is because most of the partisans of progress (taqaddum) in [Europe] seek their own private benefit and are concerned with their own power and honour, more than with the growth of their people in knowledge and culture. For this reason we see there perfect science, grace and order, alongside ignorance, wildness, harshness, drunkenness, excessive self-love, and corrupt customs. Whatever the greatness and splendour of [European civilisation] it requires the salt of sound principles to correct it; without this, its life will be confused and short, and its power weak and mean. ${ }^{314}$

Even the greatest civilisation needs 'sounds principles' to prosper: Europe can be judged against Bustān̄̄’s universal definition of tamaddun and found wanting. Syria, of course, is found still more wanting; but the acceptance of the superiority of the West does not entail the uncritical adoption of all of its standards:

Thus the Franks possess a great deal of civilisation - indeed, taken as a whole they are at a higher degree of civilisation than that of the sons of the East, and consequently than the sons of this country, which was in its turn in past ages a cradle of civilisation and a centre of taste and splendour. And since everything strange or new has a certain glamour, and the age is Frankish, and Frankish customs and taste have greater power for Easterners than [the civilisation already possessed by Easterners], and will necessarily overcome it, it is to be feared that most of the people of our country [...] will content themselves, as far as civilisation is concerned, with imitating whatever they can of the Franks' customs, clothing and virtues, imagining that that is sufficient for them to be numbered among the civilised, and to elevate them above the sons of their race and the people of their country. They do not realise that it will only make them strangers in the eyes of their fellow-countrymen, and despised as imitators, borrowers of customs, or wearers of clothes they do not deserve, in the eyes of foreigners. ${ }^{315}$

This is the chief danger Bustānī warns against: counterfeit civilisation, meaning the blind imitation of the West. This had been, in 1859, the theme of Khūrì's Way, idhan lastu bi-

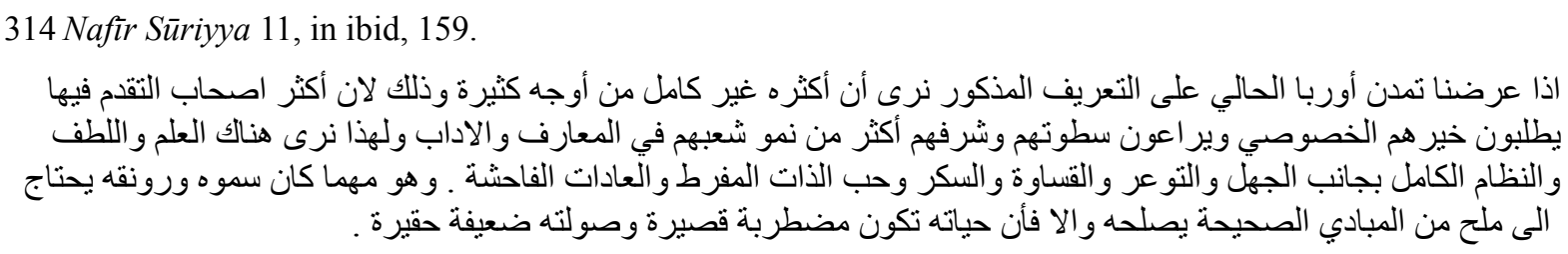

315 Ibid.

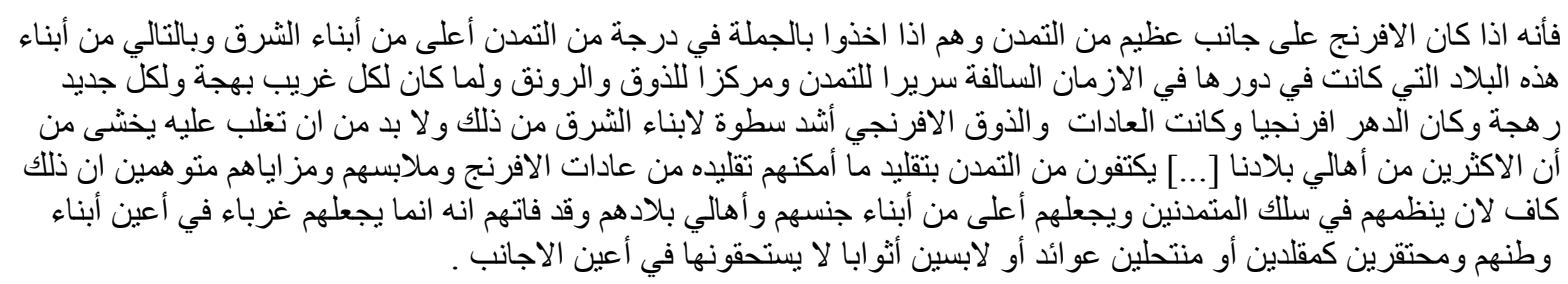


Ifranjī, and became a common refrain. ${ }^{316}$ Bustānī is careful also to mention the past

eminence of Syria: tamaddun can thus appear as a universal project, embracing Syria and

Europe, the past and the present. ${ }^{317}$ The actual civilisational status of Syria, however, is

deeply ambiguous. After the passage on Europe quoted above, Bustānī states that Syria,

before the recent violence, had appeared to be on the first rung of the ladder of tamaddun,

but has since suffered a setback. Yet elsewhere in Nafïr Süriyya he emphasizes that Syria is

capable of attaining, indeed ideally suited to attain, the highest degree of civilisation. ${ }^{318}$

Bustānī refers to the civilised past of Syria, as we have seen; yet his reading of a history of

the country (perhaps Tannūs al-Shidyāq's Akhbār al-A yān fì Jabal Lubnān, which he was

then editing) leads him to admit gloomily that much of its history has been animated by

sectarianism of a tribal or religious nature, implicitly hostile to tamaddun. ${ }^{319}$

The crux of his argument in the eleventh wataniyya is this:

Although we maintain that taking useful things $(f a w \bar{a}$ 'id $)$ from any land or people is a thing favoured and accepted among all reasonable people; that most of the useful things of civilisation come to us from Western lands; and that many of the people of Europe deserve full respect, we cannot accept absolutely and blindly that everything that comes to us from there is useful in itself and suitable for the success of Easterners and the climate of their countries [...] We know that those who accept and cling to everything that comes to them from the Frankish lands, without exact scrutiny, sound criticism, and selection of only the best, which will be useful for their progress and refinement as for the Franks, merely deceive themselves: they grasp the

316 The famous example of 'Abdallāh al-Nadīm's “Arabī tafarnaj' is discussed in Selim, The Novel and the Rural Imaginary in Egypt, 1880-1985, 50-52. For later North African instances and a discussion of the 'invention of authenticity', see James McDougall, History and the Culture of Nationalism in Algeria (Cambridge: Cambridge University Press, 2006). It is worth noting that solicitude for the 'authentic' or 'native' culture against corroding Western influences was common among European as well as Arab writers: see, for instance, James Lewis Farley, Two Years in Syria (London: Saunders and Otley, 1858); Ronald Storrs, Orientations (London: Nicholson \& Watson, 1943); and classically, T. E. Lawrence, Seven Pillars of Wisdom: A Triumph (London: Manning Pike, 1926). Sarkar, Writing Social History discusses overlaps between European orientalist and Indian elite-traditionalist versions of authenticity.

317 We should recall here the interest, then spreading among Syrian intellectuals, in the Syrian past: Khalīl alKhūrī's first book, Kharābāt Sūriyya (The Ruins of Syria), was published in 1861. For further evidence of the relevance of the Ancient past, see below, Chapter 3. The revival of the Arabic literary heritage was also, of course, a major project of the time, in which Bustānī was deeply involved: in 1860 he was secretary of al- 'Umda al-'Arabiyya li-Nashr al-Kutub al- 'Arabiyya (Arab League for the Publication of Arab Books), and editing its first publication, the Dīwān of al-Mutanabbī (1860).

318 Nafìr Sūriyya 9, in Dāyah, al-Mu 'allim Butrus al-Bustānī, 144.

319 Nafir Sūriyya 5, 1 November 1860, in ibid, 124-125. 
false dirham along with the true dinar, and exchange worn-out clothes for new rags. 320

This, then, is Bustān̄̄'s difficulty: there is a genuine universal ideal of tamaddun, which he accepts as a standard by which he and his countrymen should be judged. But in practical terms, in Syria in 1860-1, this standard is manifested largely in the civilisation of 'Western lands' - the concert of European powers which actually represented the 'civilised world' in intervening in Syria. There are two principal dangers for his countrymen: firstly and most pressingly in the context of 1860 , that they may fail to accept tamaddun, with its associated virtues of $u l f a$ and patriotism, as a standard at all, and persist in civil violence, leading to the ruin of the country. Secondly - and it is against this that he mainly warns in the eleventh wataniyya - that they should identify the genuine universal standard of civilisation simply with European civilisation, or - worse - with some of the external characteristics of European civilisation, and imitate this blindly. A subsidiary danger is that they may fall into the opposite reaction of complacency about their own Arab heritage: Bustānī thus attacks those who 'disapprove of anything simply because it is Frankish and approve anything simply because it is Arab; and vice versa. ${ }^{321}$

What comes through as an answer to this dilemma, if only negatively, is the independent activity of Syrians in the present. The implication is that the way to progress is through a critical selection from both traditions: the operative terms being fahs ('scrutiny'), intiqād 320 Nafìr Sūriyya 11, in ibid, 159-160.

$$
\begin{aligned}
& \text { ومع اننا نعتمد بأن اكتساب الفو ائد من أية جهة أو امة كانت هو من الامور المستحبة والمسلم بها عند كل عاقل وبأن أكثر فو ائد }
\end{aligned}
$$

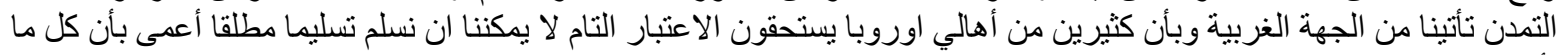

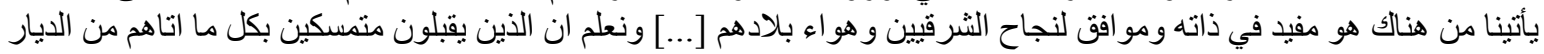

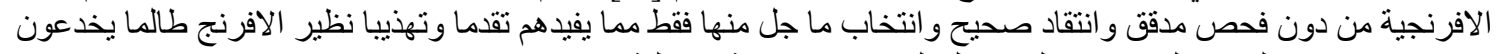

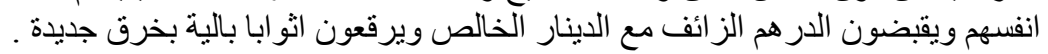

321 Ibid, 160.

$$
\text { من استهجن كل شيء لاجل مجرد كونه افرنجيا واستحسن كل شيء لاجل مجردكونه عربيا وبالعكس }
$$

Bustān̄̄ had previously denounced complacency about the Arab heritage in his Khuṭba fi Ādāb al- 'Arab (1859). Khūrî's Way, idhan..., in the same year, offered a similar two-sided critique, of 'European' complacency on the one hand and 'Arab-heritage' complacency on the other: for instance, he pokes fun at the Classical Arabic poet al-Mutanabbi before criticising the 'orientalist' prejudices of the modern French poet Lamartine. 
('criticism'), and intikhāb ('selection'). ${ }^{322}$ They denote the activities, not simply of a just ruler, but more importantly of Syrians of a certain social standing, belonging to the community of notables that is also the community of knowledge, not the ignorant commoners. The latter are perhaps indeed supposed to be civilised at some stage, but only through the agency of their 'leaders' can this be accomplished.

The pressure of Western opinion, of Western standards, the anxiety of Bustānī as he responds to these, are indeed, as Stephen Sheehi has argued, in evidence throughout Nafïr Süriyya, and the concept of tamaddun is very much a part of this. We can see how, in retrospect, Bustān̄̄ss remarks on tamaddun in Nafìr Süriyya appear to mark the beginning of an adoption of a teleological, Europe-centred standard of progress and civilisation. ${ }^{323}$ But if Bustānī takes Western tamaddun as the principal model for the tamaddun that must be constructed in Syria, he does not see it as a perfect or even, finally, as a sufficient model. The importance of tamaddun is not that it is a decisively new concept taken from Western sources, but that it can draw on both external and local cultural authority, and provide the ground on which inherited notions and imported ones can meet. If it opened up the way for the adoption of Western standards, it did so, often, in local terms. One of the most revealing passages of the eleventh wataniyya is that where Bustāni provides examples to illustrate the distinction between civilised and uncivilised:

The savage man stands in the same relation to the civilised man as the ignorant man to the wise man, or the beast to the man, or darkness to light, or the blind man to the sighted; or in the same relation as the monsters of farthest Africa, who eat one another, to the great men and nobles of Paris or England; or in the same relation as the Arabs who inhabit the desert ('Arab al-bādi'a) to the inhabitants of Beirut, for instance. ${ }^{324}$

\footnotetext{
322 The argument and the conclusion were both to persist, even as some of the terms changed: see, for instance, Muhammad al-Muwayliḥ̄ on 'al-madaniyya al-gharbiyya', in Hadīth 'Īsa ibn Hishām (1898-1902/1907: see Allen, A Period of Time). The tone was to change too: Bustānī's warning against blind acceptance becomes in Muwaylihī the despairing diagnosis that this has already happened. 323 As Ussama Makdisi has argued: 'After 1860,' 614. 324 Nafìr Sūriyya 11, in Dāyah, al-Mu 'allim Butrus al-Bustānī, 156-157.
} 
In the last two examples, we can see the merging of an external, indeed a Western imperial distinction, with an inherited elite Arab one - and both distinctions operate to exclude and repress, as well as to include and enable. The concept of tamaddun thus provided a way of drawing on the cultural authority of both the Syrian and Arab past, and the European present, in the interests of what was ultimately a local, elite-based, project of social order and reform. Civilisation - which had previously existed in the East - could exist there in the future too, and Easterners could participate in it as well as Westerners. This marks the vision of Nahda writers like Bustānī off from that of European 'orientalists' (in Edward Said's sense), to whom Easterners were necessarily inferior and the East could only be civilised by Western agency. But in either version there was a definite line between the civilised and the uncivilised or barbarous, and the former must rule (and hopefully improve) the latter. (See also below, Chapters 3 and 4.)

\section{Consolidation in the 1860s; Civilisation and Society}

1860-61, and Bustānī's Nafìr Süriyya, may be seen as a crucial moment in the emergence of the discourse of civilisation, as the concept in relation to which, more than any other, the Nahda was to make its judgements. Through the 1860 s and 1870 s we can see the consolidation of this discourse, as its vocabulary became the common currency of the Arabic press and educated discussion. The most central term was probably tamaddun; and Arab writers continued to produce definitions and descriptions of 'civilisation' through the period:

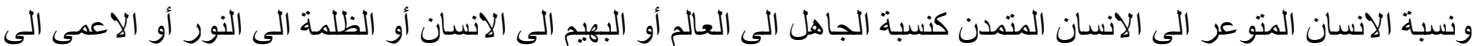

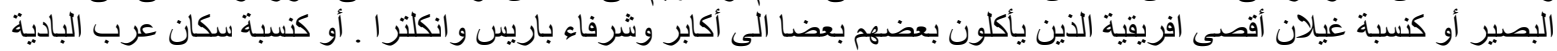

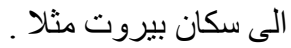


Bustānī in his dictionary Muḥịt al-muḥ̂̀t , and his encyclopedia, Dā'irat al-Ma 'ârifi; ${ }^{325}$ Fransī̄s Marrāsh at some length, as we shall see, in his utopian vision of tamaddun, Ghābat al-Haqq. Shidyāq offered a definitional article in $1861,{ }^{326}$ while Ṭahțāwī devotes whole chapters to expounding 'civilisation' in Manāhij al-albāb (1869) and al-Murshid al-amīn (1872). ${ }^{327}$

Closely grouped around the central term tamaddun were terms which suggest a distinct programme of 'civilisation': 'reform' (al-iṣlāh), 'the spirit of the age' (rūḥ al- 'așr), advancement or progress (irtiq $\bar{a}$ ' or taqaddum), success (al-najāh). ${ }^{328}$ In the more specialised sense of civilisation as 'culture', there are terms - generally older ones, but shifting in meaning - like education or cultivation (tarbiya, tahdhīb, or tathqīf - from the latter of which came the early twentieth-century coinage thaqāfa for 'culture), the sciences and arts (al-'ulüm wa-l-funūn), knowledge (al-ma'rifa). Then there are those which indicate a new sense of the society, nation, or public which, it is hoped, is becoming civilised: the homeland (al-wațan), 'society' or the 'social body' (al-hay'a al-ijtimà 'iyya), the public (al-jumhūr). Some of these 'keywords', still relatively novel, were the subject of definitions and descriptions like those offered for tamaddun, ${ }^{329}$ or programmatic calls to arms, like Khūrī’s epistle or Nafir Sūriyya.

Alongside such explicit definitions, this vocabulary was now being used in debate and informative, didactic writing on a great range of topics: Bustānī’s al-Jinān in particular, founded in 1870, carried many articles with titles such as 'al-Mar'a bayn al-khushūna wa-1-

325 See Bou Ali, 'Hall of Mirrors', Ch. 4 and passim for stimulating readings in these and Shidyāq's texts on tamaddun. See also 87-88 for a general survey of Bustān̄̄s writings and journalism.

326 'Fī al-tamaddun', al-Jawā' ib 6 (5 July 1861): partial translation in ibid., 253-4.

327 For another discussion of 'civilisation' in the nahda discourse, taking in some of these sources, see Johannes Stephan, 'Aspekte Des Tamaddun Als Formen Des Säkularen: Eine Untersuchung Des Arabischen Zivilisationskonzepts Im Werk von Fransīs Marrāš (1835-1874)’ (Masters thesis, Universität Bern, 2011), 7-26.

328 It is mainly these terms that al-Sharīf sees as making up the 'discourse of the Nahda': 'Qirā'a fĩ khițāb 'aṣr al-nahụa', in 'Rihānāt al-Nahḍa.

329 E.g. articles entitled 'al-Iṣlāḥ', al-Jinān 1 (1870): 129; al-Jinān 2 (1871): 177, 213, 249; and 'Rūḥ al- aṣr', al-Jinān 1: 385 . 
tamaddun' (by Fransīs Marrāsh); 'al-Ḥarb wa-l-tamaddun'; 'al-Tamaddun wa-l-jahl'. ${ }^{330}$

Articles and discourses on economics, trade, industry, agriculture; on history and geography; on education, law, politics, all made use of a vocabulary which had now become common and familiar. ${ }^{331}$ Meanwhile, serialised novellas - those of Butrus al-Bustānī’s son Salīm in al-Jinan especially - were elaborating tamaddun as a standard by which not groups but individuals might be judged. ${ }^{332}$ This brought with it another set of words, some of which we have seen in Bustānī, relating mainly to private life: elegance (zurf), taste (dhawq), art $($ fann $) .333$

In all this, tamaddun itself was becoming less a focus of attention, and more a known and assumed standard, by which other concepts - or groups, institutions, individuals - could be judged. Butrus Abu-Manneh has summarised, for instance, the ways in which the term was used, across a wide range of areas, by Aḥmad Fāris al-Shidyāq in al-Jawā 'ib:

$[\mathrm{H}]$ e gave a wide definition of tamaddun. Sometimes it is understood as excelling in sciences and learning or being polite and friendly, or being correct and straightforward in transactions, or cooperating between people, ignoring differences of belief or sect, or "if we define it as the growth of industry, handicrafts and commerce, no two persons disagree". ${ }^{334}$

Tamaddun and related concepts like the 'spirit of the age' or 'reform' did not need, in this kind of writing, to be explicitly defined or enthusiastically proposed; rather, this way of thinking - civilised, bourgeois - was assumed, as an accepted framework. By the 1870s we might suggest that it had become almost an 'empty signifier', so widely had it been used to indicate approval (and its absence, disapproval) in the Arab press. ${ }^{335}$

330 Al-Jinān 1 (1870): 462, 504, 600 respectively.

331 See, for instance, the discourses collected in Yūsuf Qizmā Khūrī, ed., A 'māl al-Jam 'iyya al- 'ilmiyya alSūriyya, 1868-1869 (Beirut: Dār al-Ḥamrā', 1990).

332 See Zachs, Making of a Syrian Identity, 71-74.

333 On the last-mentioned, see Mestyan, 'The Origin of Fann'.

334 'Shidyaq, al-Jawa' ib, and the Call for Modernity in Ottoman Lands', in The Economy as an Issue in the Middle Eastern Press, ed. Gisela Procházka-Eisl and Martin Strohmeier (Münster: LIT Verlag, 2008), 21. 335 Zachs, Making of a Syrian Identity, 72 notes the difficulty of pinning 'tamaddun' down to a specific meaning. 
It is instructive, from this period of the consolidation of the discourse of tamaddun, to select out a particular example, again from the writings of Buṭus al-Bustān̄̄, which enlarges on a term he had associated closely with tamaddun in Nafìr Süriyya: al-hay'a al-ijtimā 'iyya, the 'social body' or perhaps 'social organism'. In 1861, we remember, he had written that 'true civilisation'

extends to all the conditions of the public (jumhür), organized in a social body (hay'a ijtima 'iyya) under specific bonds ${ }^{336}$

Here the 'public', jumhūr, is a group of people in the mass; it becomes a society, a social body or organism (and thus capable of becoming civilised) only when 'organized' (muntazam). In his 1869 Discourse on the Social Body (Khițāb fì al-hay'a al-ijtimā 'iyya) delivered to the Syrian Scientific Society, Bustānī goes into more detail:

The social body means the inhabitants of a country or a city, who have shared interests; or to be exact, it is the condition that results from human sociability (alijtim $\bar{a}^{\prime}$ al-bashar $\left.\bar{\imath}\right)$. The real and natural foundation of human sociability is simply the needs (ihtiyajjāt) and fears of individuals (al-afrād); moreover, to the extent that the needs are widespread and important, and the fears varied and powerful, that basis is firm, and its bonds and relations are strong. ${ }^{337}$

The argument is similar to that made in the passage cited above (p. 72) on the common interests of the sons of the watan. But we cannot fail to note the continuity from Ibn Khaldūn:

One knows from philosophical works the statement that 'man is political (madan $\vec{\imath}$ ) by nature.' The philosophers cite that statement in connection with establishing the existence of prophecy and other things. The adjective 'political' (madan $\bar{\imath}$ ) refers to the 'town' [polis], which they use as another word for human social organization.

The statement means that a single human being cannot live by himself, and his

336 Nafìr Sūriyya 11, in Dāyah, al-Mu 'allim Buțus al-Bustān̄̄, 157.

$$
\text { يمتد الى كامل أحو ال الجمهور المنتظم في هيئة اجتماعية تحت رو ابط معينة }
$$

337 Khițāb fi al-hay'a al-ijtimā 'iyya, in Dāyah, al-Mu 'allim Buṭus al-Bustān̄̄, 163-164.

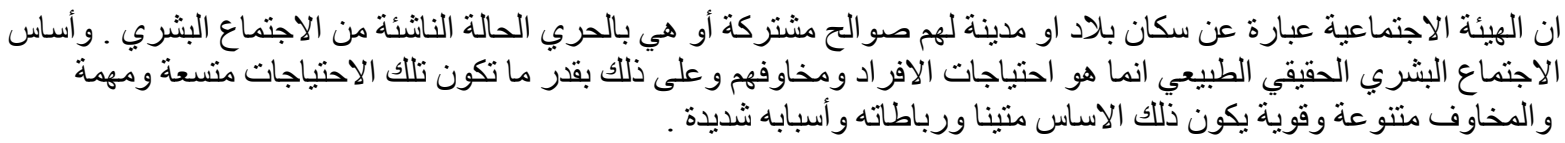


existence can materialize only in association with his fellow men. [Alone,] he would be unable to have a complete existence and lead a complete life. By his very nature, he needs the co-operation of others to satisfy all his needs. Such co-operation requires, firstly, consultation, and, then, association and the things that follow after it. Dealings with other people, when there is oneness of purpose [may lead to mutual affection, and when the purposes differ, they] may lead to strife and altercation. Thus, mutual dislike and mutual affection, friendship and hostility, originate. This leads to war and peace among nations and tribes. ${ }^{338}$

This itself refers back to Aristotle's 'man is political (madanī) by nature': Ibn Khaldūn glosses this concept in terms of al-ijtimā' al-insānnì; and Bustānī, likewise glosses 'the social body’ in terms of al-ijtim $\bar{a}^{\prime}$ al-basharī, reaching back to the Khaldūnian tradition if not Ibn Khaldūn himself. (The continuity from the Greek polis through madanī to tamaddun in the nineteenth century is also relevant: see above, p. 98 note 275.) Fārābī, in The Virtuous City, had also been writing in this tradition, when he referred to 'The need of mankind for society and cooperation' (Ihtiyyāj al-insān ilā al-ijtimā' 'wa-l-ta 'āwun) $)^{339}$ as had Miskawayh when he, like Ibn Khaldūn, quoted Aristotle. ${ }^{340}$

In many ways the form of Bustānī's argument is remarkably similar to that of the older writers, and suggests the possibility of direct imitation or influence, from some part of the tradition if not directly from these particular writers. ${ }^{341}$ But a crucial change has taken place.

338 From the opening of Ch. IV, part 3 of the Muqaddima, 'The experimental intellect and how it comes into being'. Translation adapted slightly from Ibn Khaldūn, The Muqaddimah: An Introduction to History, ed. Franz Rosenthal, trans. N. J. Dawood (New York: Pantheon, 1958), 2: 417. I follow Rosenthal in assuming an omission in the text between 'purpose' and 'may lead', and in supplying this: see his note 15a.

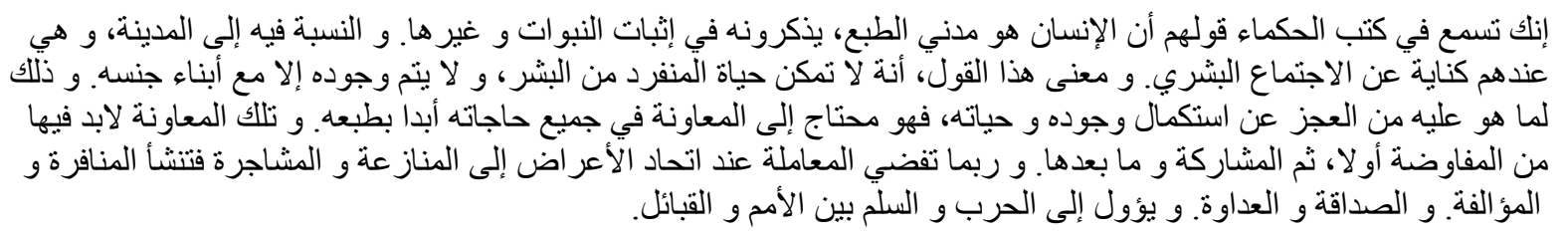

Cf the general discussion near the start of the Muqaddima: Ch. I, 'On human civilisation in general', First Prefatory Discussion: Ibn Khaldūn, The Muqaddimah, 1: 89.

339 This is the title of Ch. 26 of al-Madinna al-Fädila.

340 Antony Black, The History of Islamic Political Thought: From the Prophet to the Present, 2 nd ed. (Edinburgh: Edinburgh University Press, 2011), 70, 58.

341 Ibn Khaldūn had enjoyed a vogue in Ottoman literary-official circles in the sixteenth and seventeenth centuries: see Cornell Fleischer, 'Royal Authority, Dynastic Cyclism, and "Ibn Khaldûnism" in SixteenthCentury Ottoman Letters', African and Asian Studies 18, no. 3 (1 January 1983): 198-220; and Virginia H. Aksan, 'Ottoman Political Writing, 1768-1808', International Journal of Middle East Studies 25, no. 1 (1993): 53-69 for the development of this tradition into the early nineteenth century. It is uncertain to what extent these Ottoman discussions would have affected a Syrian like Bustānī; but the Muqaddima was 
For Ibn Khaldūn, 'the isolated human being' (al-munfarid min al-bashar) could only complete his existence 'with the sons of his species' (ma 'a abna' jinsihi), from whom he was 'in need of aid' (muḥtāj ilā al-mu 'āwana). For Fārābī, 'mankind' (al-insān) stood in need (ihtiyāj) of 'society and cooperation' (al-ijtimā' wa-l-ta 'âwun). 'Mankind' here is a whole, a species (jins), while ijtima ' is perhaps best translated as 'society', but in the older English sense of 'the company of one's fellows', or 'sociability': it is a property of the human species. (It occurs, often, in conjunction with the similar terms $i^{\prime} t i n a \bar{s}$ and $u n s$, from the same root as insān itself.) The case of 'the isolated human being', separated from his fellows, to which Khaldūn refers, is a hypothetical case: the whole argument of these older writers is that a single human being is dependent upon and thus inseparable from the rest of mankind.

In Bustānī, the apparent thrust of the argument is the same: the need of humans for 'society'. But Bustānī is already beginning to think, less of 'sociability' as a natural propensity of mankind, but of 'society' in the modern English sense, as an object, separate from the particular people who comprise it. And the term for this is 'the social body' (al-hay'a alijtimā' iyya), which is 'the condition that results from human society' (al-ijtimā' al-bashar $\bar{l})$. This is then explained, not as a result of a 'need' (ihtiyāj $)$ of mankind in general (as in Fārābī), but in terms of the 'needs (ihtiyājāt) and fears' of 'individuals' (al-afrād). The shift is subtle, and disguised by the continuity of the language - ihtiyāj/ihtiyajāat, ijtimā' 'ijtimā 'iyya, munfarid/afrād - but it is also radical. 'Individuals', in a new, strong sense, can now be seen as existing separate from, and indeed prior to, a similarly reified 'society': the 'needs and fears' they feel, as individuals, then compel them to take refuge in it. The notion of a separated individual is reinforced, a few pages later, by the example of

printed in Arabic, at Bulaq, in 1857. 
Robinson Crusoe (whose story Bustānī was of course then translating). ${ }^{342} \mathrm{He}$ is cited as an illustration of the difficulties a single individual has in providing for all his needs alone: this again reinforces Bustān̄̄'s point, on the necessity for society (as well as the division of labour), but not by reference to a hypothetical example (Ibn Khaldūn's al-insān al-munfarid) but rather a particular, isolated individual, who can now stand for a general type: the individual, as against the new, reified sense of society.

The shift to these newer meanings, from the older sense of mankind as a species and a category, with the necessary property of sociability (as a social or 'political' animal), is analogous to that described in English culture by Raymond Williams. ${ }^{343}$ In the older version, 'the ground of human nature is common; the 'individual' is often a vain or eccentric departure from this'. In the newer, 'Argument began from individuals, who had an initial and primary existence, and laws and forms of society were derived from them'. ${ }^{344}$ This came to be characteristic of Enlightenment thinking and especially of political economy, which began from an origin myth based upon individuals who then decided to cooperate. ${ }^{345}$ (Robinson Crusoe - as Marx noted - was often employed as an illustration.) $)^{346}$ It was, in fact, as Williams suggests, one of the deep forms of bourgeois thinking: it emerges in another way in the separation of the private (or domestic) and the public spheres, and, later, in a separation of (European) literary traditions, into writing on public affairs and on personal relations. ${ }^{347}$ Bustānī is, in a sense, adopting the terms of Enlightenment and bourgeois debate, and from European sources: his reference to individuals' 'needs', in particular, like his earlier account

342 Dāyah, al-Mu 'allim Buțrus al-Bustān̄̄, 166; Hill, 'Early Arabic Translations'.

343 The Long Revolution (London: Chatto \& Windus, 1961), Ch. 2, 'Individuals and societies'; Keywords, 'individual' and 'society'.

344 Keywords, 162-3.

345 David Graeber, Debt: The First 5,000 Years (New York: Melville House, 2011) opens with a useful, polemical account of these economical 'origin myths' and their continued influence today.

346 There is an illuminating discussion of this question in relation to Bustānī in Bou Ali, 'Hall of Mirrors', 141-2.

347 See The English Novel from Dickens to Lawrence (St Albans: Paladin, 1974). 
of 'profits and losses' in Nafïr Süriyya, seems to gesture towards the Utilitarian calculus of

human need. But we can still see the pull of the older senses, of the tradition of al-ijtima $\bar{a}^{\prime} a l$ insāni, and his intention, not simply to switch abruptly from one to the other, but to argue through the transition, even at the cost of some ambiguity. His 1869 Discourse may be seen as a similar point of transition to that which Williams located (for English) in Hume's Enquiry Concerning the Principles of Morals (1751), with its uses of 'society' in both the old and the new senses, as well as many crucial 'intermediate' cases. ${ }^{348}$

\section{Class Confidence: Beirut 1869}

If this is the way Bustānī deals with 'society' in general, it is instructive to turn to his account of it in the specific context of the Beirut of 1869: that now prosperous and peaceful 'society' dominated by self-interested bourgeois 'individuals'. In the Discourse he makes three points which justify the optimism he now feels:

First, most of the people of Beirut are lovers of public peace and stability ( $r \bar{a} h a)$, and have common interests (șawälih mushtaraka). They are made up of owners of industries, merchants, property-owners and leaders; the number of the rabble (al$a w b \bar{a} s h)$ in [Beirut] is very small compared with other cities.

Second, in Beirut there are persons of different countries (buldān) and races (ajnās) [...] these fall into two groups: Easterners and Westerners. Though they may differ in the matter of nationality (al-jinsiyya) and taste (al-mashrab), they have common interests, especially commercial (tijāriyya), civil (madaniyya) and moral (adabiyya); and if they wish, they may live together in security, ease, affluence and prosperity. Yes, there are at times some of the rabble ( $a w b \bar{a} s h)$ who have been thrown out by the purity of their country or the severity of its laws or other reasons to this country, in order to undermine [it] and destroy stability and public security; and some of the riff-

348 Keywords, 293; Raymond Williams, Writing in Society (London: Verso, 1983), 139-141. I have argued that Bustānī tends to modify the individualism of Robinson Crusoe in the direction of a collective (patriotic) project: Hill, 'Early Arabic Translations'. This perhaps indicates a similar ambiguity in his position. For later developments of 'al-hay' a al-ijtimā iyya' as a term (and its replacement by al-mujtama ), see Charles Tripp, Islam and the Moral Economy: The Challenge of Capitalism (Cambridge: Cambridge University Press, 2006); and Timothy Mitchell, Colonising Egypt (Berkeley: University of California Press, 1991); for 'individualism' in the generations after Bustani, see Donald M. Reid, 'Syrian Christians, the Rags-toRiches Story, and Free Enterprise', International Journal of Middle East Studies 1, no. 4 (1970): 358-67. 
raff $\left(r a^{\prime} \bar{a}\right)$ of our country may join them in this. But the sound ties and affection between the remainder of the population, both sons of the homeland and foreigners, tends to cure or prevent whatever harm may befall this country of ours from those vicious people.

Thirdly, most of the inhabitants of Beirut are civilised (mutamaddinūn); all their sympathies ( 'awātif) are directed towards civilisation and incline to it. They are strongly concerned with widening the circle of [civilisation] in their country and spreading its benefits in other places. Thus their needs (ihtiyajjāt) are the needs of a civilised people (qawm), as are their fears (makhāwif). So, in order that their social order should correspond to their needs, and that they should enjoy the results of that state of affairs, those needs must be properly fulfilled, and every one of those fears driven away. ${ }^{349}$

The emphasis, as earlier in the Discourse, is on unity through 'shared interests', here less of individuals than of potentially opposed groups: and these are Easterners and Westerners. The need for the unity of different religious sects among the 'sons of the homeland', the great theme of Nafir Süriyya, has dropped into the background. But it seems quite clear (as suggested above, Chapter 1, p. 72) that what Bustānī is defining here is a shared class interest, among both 'sons of the homeland' (of all sects) and foreigners, as against the 'rabble' or 'riff-raff', seen as largely coming from outside Beirut itself (as in the characteristic pattern of blaming the sectarian violence in Damascus or Aleppo on outsiders). But even taking into account these outsiders, 'the number of the rabble is small', while 'most of the people $(a h \bar{a} l \bar{l})$ of Beirut' are capitalist and property-owners, or 'leaders' in the older 'notable' sense ( $\bar{u} l \bar{a} t$ al-umūr). This statement is presumably not an accurate statement of relative numbers - the actual number of the poorer classes in Beirut, we may presume, 349 Khiṭāb fí al-hay'a al-ijtimā 'iyya, in Dāyah, al-Mu 'allim Buṭus al-Bustān̄̄, 167-168.

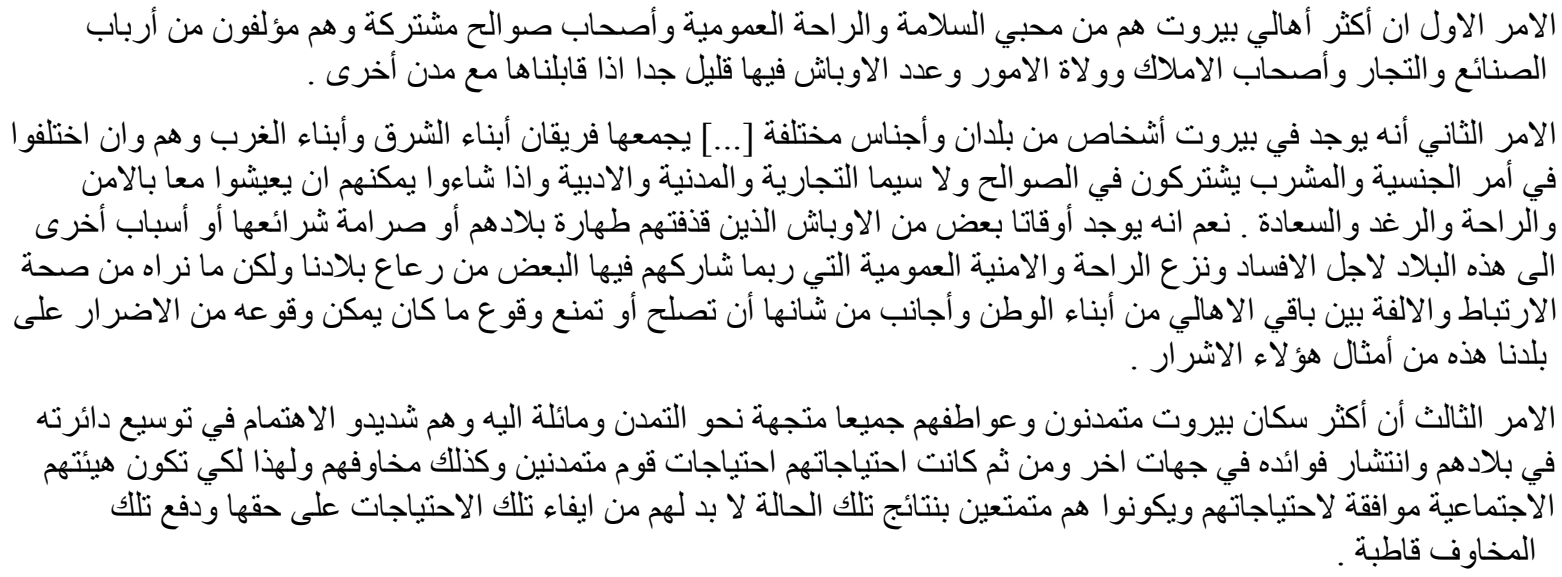


outnumbered that of the class Bustānī describes - but may be quite an accurate reflection of the relative social power of different classes in the city. Though the poor may have been in fact quite numerous, they were not visible, powerful or threatening (as they so notably had been, elsewhere, in 1860-61): the class unity of 'sound ties and affection' can easily deal with them. This indicates, then, a point we have touched on in the previous chapter - the exclusion of the poor from the social settlement of 1860 - and suggests that this may in fact have been greatest in a city like Beirut, where the scope for the new sectarian-populist politics indicated by Ussama Makdisi was most restricted. It was only towards the end of the century that Beiruti workers were to develop effective forms of industrial action, and that a new 'radical' politics was to take up their cause. ${ }^{350}$

At the same time, Bustānī's definition of the 'people' (ahālì) of Beirut, who are mostly 'civilised', is substantially different from that of the older separation between the 'people' or 'commoners' and an elite. Although the older kind of 'notables' (the $\bar{u} l \bar{a} t$ al-umūr) are included in Bustānī's 'people', they are in no sense the predominant group, over industrialists, merchants, and property-owners, whose wealth and social power was clearly economic in origin, rather than extra-economic (tax-farming or hereditary shaykhly status). The new property-owning class is open to those from outside the ranks of the old notability: it is not a particular elite of known persons, the khawāsș, wujūh or a $y \bar{a} n$, with their connotations of face-to-face relations. Like the 'public', jumh $\bar{u} r$, it can involve impersonal and anonymous forms of solidarity - its common 'interests' may be shared, and felt to be shared, by people who have never personally met. ${ }^{351}$ And by making this class practically

350 Donald Quataert, Erik Jan Zürcher, and International Institute of Social History, Workers and the Working Class in the Ottoman Empire and the Turkish Republic, 1839-1950 (London: Tauris, 1995); Khuri-Makdisi, The Eastern Mediterranean and the Making of Global Radicalism.

351 This anonymity of a class of interchangeable individuals has been seen as a major innovation of the bourgeoisie: Ernest Gellner, Nations and Nationalism (Oxford: Basil Blackwell, 1983); and for its literary and cultural aspect, Benedict Anderson, Imagined Communities: Reflections on the Origin and Spread of Nationalism (London: Verso, 2006). 
synonymous with the term 'people', ahālī, which had earlier referred mainly to the commoners (and often, as above, to the commoners as distinct from the notables), Bustānī can sustain a pretension to universality. The 'shared interests' of what is in fact a limited class become those of 'the people' of Beirut as such, from which category the 'rabble' are excluded. $^{352}$

Moreover, this unity - of a class in the economic sense, rather than a closed order or patriciate - is based not only on common material interests (sawālih), but also on the shared standards or values of tamaddun. This criterion, while uniting foreigners and 'sons of the homeland', might exclude, along with the 'rabble', other local groups: perhaps old-fashioned muqatajis in the Mountain, ignorant clerics, or those (over-eager nouveaux riches?) who believed that 'civilisation' consisted in the aping of Western fashions. And there is a new settled confidence about the civilised status of Beirut, very different from the urgency, as well as the intense shame and embarrassment, of 1860-61. The 'people' of Beirut are civilised: there is no longer that searching anxiety about what the foreigners would think: are we really civilised? Beirut is put forward almost as a utopia, with ideal conditions for tamaddun to develop. But the mood is different, too, from the near-messianism of Khūrī's epistle of 1858 (or other texts of the mid-century: see Chapter 4, 'Utopianism in the Nahda'), a young man's first flush of enthusiasm for the 'New Age'. Bustānī in 1869 is sanguine, confident, optimistic; but he offers solid reasons for his optimism, in 'shared interests' and social facts. This offers evidence, perhaps, of a change in attitude Ussama Makdisi has noted among the American missionaries, over a similar period: from the urgent sense of the 'flying of time' to a more settled, rational, 'secular modernity'.

352 The ideologues of the English Revolution had, similarly, assumed that 'the poor' could be excluded from the category of 'the people': 'Property, generally, is now with the people.... All government is built upon propriety, else the poor must rule it.' (Captain Baynes in Parliament, 1659). See Christopher Hill, Puritanism and Revolution: Studies in Interpretation of the English Revolution of the 17th Century (London: Panther, 1968), 296. 
I would stress that all three kinds of experience - the messianism of 1858, the sense of crisis and shipwreck in 1860 , the settled, even complacent optimism of 1869 - all represent real facets of the experience of these times, for those who lived through them. Stephen Sheehi (and perhaps others) has seen the experience of 1860-61, with its crisis, self-doubt and shame in the face of the West, as the foundational moment, not just for Beiruti intellectuals like Bustān̄i, but for modern Arab identity in general. ${ }^{353}$ I would suggest that if we take the full weight of the experience of those other moments - 1858, as the 'New Age' broke; 1869, as Beirut seemed most obviously to be reaping its fruits - this judgement must be qualified. I am not suggesting that it should be discounted - that we should see 1860 as an aberration, a minor blip in a narrative of steady progress. We may follow Sheehi in seeing that moment of crisis as revealing certain features which persist through the surface stability of more settled periods - but we should not see it as the whole picture. The settled prosperity of 1869 , which permitted a renewed confidence as to Syria's civilisational status, rather than shame in the face of the necessarily superior West, was a real experience too.

We need, therefore, to hold together in the same moment of thought the two sides of the experience - the confidence in steady progress and the cataclysm of violence - as they were bound together in the history. For if the arguments made in Chapter 1 hold good, then the progress of capitalism and reform, before 1860, the integration of Syria into the 'civilised world' which Khūrī hailed, must be seen as the major factor in precipitating the cataclysm. And the settled development of these processes after 1860, which licensed Bustānī's confidence, must be seen as crucially enabled by that moment of sectarian and class violence and its repression: the 'long peace' as the fruit of the months of war. Only after the old ahāli,

353 Sheehi, 'Unpacking Modern Arab Subjectivity'; Stephen Sheehi, Foundations of Modern Arab Identity (Gainesville, Florida: University Press of Florida, 2004). 
the commoners, had rebelled against the old notability, could Bustān̄'s new version of the ahāli arise - in Beirut and the Mountain at least - as a locally hegemonic class of a new kind, from which the bulk of the commoners could be excluded as 'rabble', awbāsh. And the 'civilisation', tamaddun, around which this class's ideology revolved, was no less dependent on the exclusion and repression of its opposite: some of the old rulers, to be sure, but principally the outsiders, and the uncivilised, barbarous lower orders.

\section{The Discourse of Civilisation: In Whose Terms?}

Finally, we may ask in what respects this 'discourse of civilisation' was really distinctive to the Arab Nahda. Might it not be seen simply as a local version - a set of calques or translations - of the existing European vocabulary (and ideology) of the 'age of improvement'? ${ }^{354}$ It might even be argued that some of its Arabic terms are more deeply marked in their morphology by the nineteenth-century conditions in which they were coined than are their European equivalents. Thus the etymological sense of the English 'reform' and its European cognates was simply that of re-shaping, for better or for worse; but it came to be translated in Arabic by an unquestionably positive word: iṣlāh, with the sense of making better or sounder. This was, of course, the connotation 'reform' had to forward-looking or 'progressive' European writers of the mid-nineteenth century. ${ }^{355}$ Similarly, 'progress' and its cognates indicate etymologically only 'moving forward', in 'a discoverable sequence'; ${ }^{356}$ an

354 See Asa Briggs, The Age of Improvement, 1783-1867 (London and New York: Longmans, 1959). The English version of this vocabulary is, to a large extent, that referred to by Williams in the introduction to Culture and Society 1780-1950; and later analysed in Keywords. For an attempt at a 'global' account of civilisation, see Margrit Pernau et al., Civilizing Emotions: Concepts in Asia and Europe, 1870-1920 (Oxford and New York: Oxford University Press, 2015).

355 Williams, Keywords, 262-4. The Arabic term conveyed, however, the central ambiguity Williams points to: the dual sense of 'restore to its original form' and 'make into a new form'. The relevance of this equally to the religious Reformation, the revival of Classical culture, and the 'renewal' (tajdìd) or 'revival' (nahḍ) of Arab culture or Islamic civilisation, is evident.

356 Ibid., 244. 
Arabic term often used to translate them in these years, however, was irtiq $\bar{a}$, with the sense of rising, becoming higher (though this came to be supplanted by taqaddum, a more literal translation of the etymological sense of the English 'progress' or French 'progrès'). Even these apparently ultra-'modern' examples, however, point to the difference between the Arabic and European histories: the language bears the marks not of a straightforward diffusion of European terms or ideas, but of a specific interaction with European culture at a particular period.

The specific way in which terms and concepts often, indeed, originating in Europe, were reshaped into their Arabic forms (partly through Ottoman mediation) is evident if we turn back briefly to Nafìr Sūriyya. One of the places where Bustānī, at first glance, most obviously calques the vocabulary of Western liberalism is in his discussion of the "rights and duties' owed to and by the homeland. The fourth wataniyya opens:

Countrymen: the people (ahl) of a homeland (watan) have rights over their homeland, as the homeland has duties to its people. ${ }^{357}$

And among the rights which the sons of a particular homeland can demand are

the security of the best of their rights - their blood, their honour and their property. Also among them is freedom in their civil (madaniyya), moral (adabiyya) and religious rights, especially freedom of conscience $(d a m \bar{i} r)$ in the matter of sect - how many nations have become martyrs to this freedom! $!^{358}$

This might be taken for a simple imitation of Western liberal nostrums. But the particular 'rights' Bustānī asserts here are the product of a specific combination of factors. For the first set - the security of blood (i.e. life), honour, and property - are, specifically, those provided

357 Nafìr Süriyya 4, in Dāyah, al-Mu 'allim Buțrus al-Bustānī, 121.

$$
\text { يا ابناء الوطن لاهل الوطن حقوق على وطنهم كما ان للوطن و اجبات على اهله . }
$$

358 Ibid.

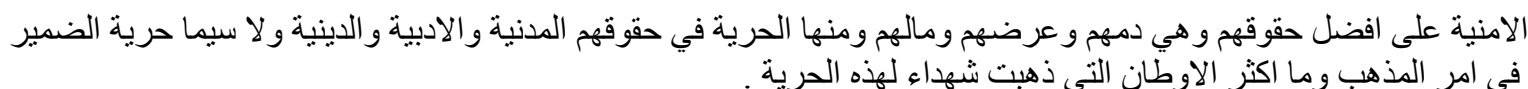


for by the Gülhane Rescript of 1839: the reference indicates loyalty to the Tanzimat project.

'Freedom in [...] civil, moral and religious rights' is more general, and appears to stretch that project a little in the direction of an active citizenry, as I have suggested. But with the specific example of 'freedom of conscience' in religion, Bustānī's own personal history and preoccupations are once relevant: he had suffered for his own conversion to Protestantism, and wrote much in favour of religious toleration (including an account of the life of the Syrian Protestant martyr, As 'ad al-Shidyāq). ${ }^{359}$ Even the final, apparently casual, 'how many nations...', reminds us of the stress laid on Catholic persecutions of Protestants during the Reformation, in many of the Protestant missionaries' translations and polemics of the period. ${ }^{360}$ The succeeding passage gives us a hint of the kind of compact Bustānī was aiming at, between reformist Ottoman governors and Syrian elites:

Among the things which increase the love the sons of the homeland (watan) feel for their homeland is the feeling that the country $($ bila $\bar{d}$ ) ) is their country, and that their happiness lies in its prosperity ( $i m \bar{a} r$ ) and stability ( $r \bar{a} h a)$, and that their misery lies in its ruin and distress. And among the things which increase their desire for its success and their zeal for its advancement (taqaddum) is that they should have a hand in its affairs, and enter into its interests: to the extent that responsibility is placed on them, these feelings grow stronger and firmer. ${ }^{361}$

Thus loyalty, and abstention from violent proceedings that might bring the country to 'ruin', is offered in exchange for 'a hand in its affairs'. This looks forward to the cooperation between Ottoman state and local elites during the 'long peace' after 1860, as well as to the promotion of local patriotisms by reformist governors, with their official journals entitled

359 See Ussama Makdisi, Artillery of Heaven: American Missionaries and the Failed Conversion of the Middle East (Ithaca, NY: Cornell University Press, 2008), Ch. 7; Hill, 'Early Arabic Translations'.

360 For instance the lives of Martin Luther and histories of the Reformation: see Nicole Khayat, 'Historiography and Occidentalism during the 19th Century Nahda: European History in Arabic' (Doctoral thesis, Haifa University, forthcoming). But see also anti-Catholic polemics like Jonas King's Farewell Letter or Mikhā’îl Mishāqa, al-Dalīl ilā ță à al-Injūl (Guide to Obedience to the Gospel) (Beirut: American Press, 1849).

361 Nafìr Sūriyya 4, in Dāyah, al-Mu'allim Buțrus al-Bustānī, 121-122.

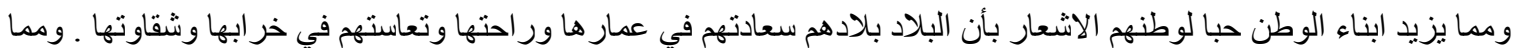

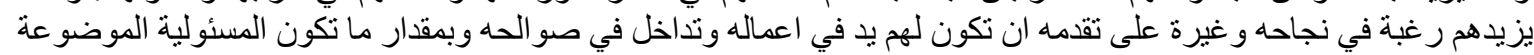

$$
\begin{aligned}
& \text { عليهم اكثر تكون هذه الحاسيات انثد و اقوى . }
\end{aligned}
$$


Süriyyā, al-Furāt, and the like: loyalty to the wațan, as part of the Empire and not in 'Arabist' opposition to it. ${ }^{362}$

This vocabulary was, then, shaped by a particular set of conditions, from which the West and Europe were never of course absent, but which cannot be reduced to a model of simple 'diffusion'. Nor, as I see it, should tamaddun, in particular, be assumed to point unequivocally towards a twentieth-, or twenty-first-century, form of 'modernity' or 'modernisation'. This point is raised in the terms used by some later scholars to translate or define tamaddun. Butrus Abu-Manneh translates tamaddun as 'modernity';363 Nadia Bou Ali, in one place (also with reference to Shidyāq), as 'Civilisation or Modernity'. ${ }^{364}$ And Fruma Zachs has defined tamaddun, in one place, in these terms: 'I have interpreted the local process of "modernization" mainly as tamaddun, as the [Syrian] merchants did.' This carries with it the useful emphasis that this was the Syrian merchants' own concept, indicating the 'specific characteristics of civilisation' adopted by 'the Beiruti bourgeoisie', rather than simply 'similarity to those of the West'. And it is in many senses right to see the Arab Nahda as the local, and specific, case of a much broader, global phenomenon ${ }^{365}$ (though whether 'modernisation', with its echoes of Rostowian modernisation theory, is an especially good description of this wider phenomenon, seems more questionable). But the difficulty of assuming that all of the meanings understood under the term tamaddun were necessarily 'modern' ones, or that they imply a repudiation of the past as such, is apparent when tamaddun itself clearly, in some cases, refers to the past. Abu-Manneh's translation of Shidyāq reads, in one place, 'isn't it that in former times modernity (tamaddun) and sciences were borrowed from the Muslims?'.366

362 See Mestyan, 'Project Jara'id'.

363 'Shidyaq, al-Jawa'ib', 18.

364 'Hall of Mirrors', 253. She also refers (95) to 'the hegemonic singular narrative of modernity that tamaddun, civilisation, stood for' (though emphasising that this narrative was contested). 365 As I have previously argued: 'Revisiting the Intellectual Space of the Nahda'. 366 'Shidyaq, al-Jawa' 'ib', 18. The reference is to Kashf al-Mukabbā' (Istanbul, 1299 [1881/1882]), 4. 
I would suggest that the English translation as 'modernity', here, confuses more than it clarifies; and, further, that one of the strengths of tamaddun as a term was precisely its vagueness, its wide potential range of reference. A Nahda writer would often, indeed, refer to the need for civilisation in the contemporary Arab lands, in the sense - as Abu-Manneh says of Shidyāq, of 'social and economic reform'. ${ }^{367}$ He could also refer to the civilisation of contemporary Europe or the 'civilised world', understood as Europe or the West, as examples to be learnt from (though rarely in an uncritical way). He could refer to degrees of civilisation between Syria or Egypt and Europe, or between the Syrian interior and Beirut. ${ }^{368}$ But he could also refer to the civilisation of Ancient peoples - a heritage not merely European but also belonging to the lands of Syria or Egypt, the homes of the ancient Egyptians and Phoenicians - he could refer to the past civilisation of the Arab and Muslims (perhaps following the example of European orientalist scholarship, as Jurjī Zaydān did in his Tārìkh al-tamaddun al-islāmì). And this range of potential reference - to other places and times besides the contemporary West and Ottoman-Arab lands - permitted a certain relativisation of the claim that 'modern' Europe was the only model of tamaddun - as we have seen above with Bustānī.

The assumption that Nahda writers either were, or ought to have been, iconoclastic 'moderns', intent on erasing every trace of the past as the opposite of 'modern civilisation', has left later scholars bemused, or dismissive, in the face of - for instance - the 'archaising' tendencies in the literature of the period, from Nāṣîf al-Yāzijī and Shidyāq to Muḥammad alMuwayliḥ̂̄'s Hadīth 'Isa ibn Hishām. ${ }^{369}$ I would suggest instead that tamaddun, during the

367 Ibid.: Shidyāq was 'a thinker and a promoter of social and economic reform, in short, of tamaddun'. 368 As for instance in Fransīs Fathallāh Marrāsh, Kitāb Riḥlat Bārīs (Beirut: al-Maṭba a al-Sharqiyya 'ind Hannā Najjār, 1867).

369 See, for instance, Matti Moosa, The Origins of Modern Arabic Fiction, 2nd ed. (Boulder, CO and London: Three Continents Press, 1997), 2; Gaston Wiet, Introduction à La Littérature Arabe (Paris: Maisonneuve et Larose, 1966), 273 (on Yāzijī). 
mid-nineteenth century at least, offered a slogan under which certain (necessarily selective) versions of the past, as well as contemporary European and other examples, and 'reformist' programmes, could be united. It was only later, towards the end of the century, that this unifying discourse of tamaddun was to split apart, under new pressures, into a modern 'Western civilisation' (al-madaniyya al-gharbiyya) on the one hand, and an Arab or Muslim 'heritage' (turāth) or 'civilisation' ( 'umrān). ${ }^{370}$

I am not suggesting, of course, that the discourse of tamaddun in the mid-nineteenth century was itself a mere survival or revival of an Arab or Islamic 'heritage': merely that the appearance of some continuity was necessary to it. We are looking, perhaps, at another examples of what Williams has called 'the confused way in which an idea changes, under an apparent continuity of terms', ${ }^{371}$ We will see in the next chapter some instances of the subtle rewriting of 'modern' European texts by Nahda writers; but there were also many rewritings of 'Classical' Arabic writers. We have already seen Bustānī's recrafting of, if not Ibn Khaldūn directly, at least the Khaldūnian tradition of writing on 'human society'. If we may take an example from elsewhere, we can note that Ṭahțāwī was especially subtle in his procedures: Manal Gamal al-Din Hosny has commented on a passage from his Manāhij alalbāb which she initially took for a paraphrase of a French Enlightenment pedagogue, but which turned out to be an unattributed quotation from Miskawayh; in another case, a phrase about 'progress', taqaddum, is carefully selected from Māwardī’s Adab al-dunyā wa-l-dīn, in such a way as to suggest less Mawardi's sense of the word than 'un progrès dans le sens européen du mot'. ${ }^{372}$ The point to retain is that the conflation between Classical Arabic sources and 'modern' or European ones was intentional: as Hosny comments, 'Tahtawi ne

370 As in Muwaylihị’s Hadīth 'Īsa: Roger Allen, A Period of Time (Reading: Ithaca, 1992), 'al-Madaniyya algharbiyya'.

371 Modern Tragedy (Peterborough, ON: Broadview Press, 2006), 46-7.

372 Manal Gamal El Din Hosny, 'Tradition et Renouveau Dans L'oeuvre de Tahtawi' (Doctoral thesis, Alexandria University, 2001), 86, 115-6. 
compile pas simplement ses textes, il sait choisir judicieusement les passages qui illustrent le mieux son idée.' This kind of intertextual blending could offer a 'traditional' as well as a 'modern' or forward-looking legitimation to the discourse of tamaddun, and thus to the classes - the Beiruti bourgeoisie or the new Egyptian or Ottoman officialdom - who claimed it as their own. 


\section{Chapter 3}

\section{A Place in the World}

The nature of every virtuous person, indeed of every human being, longs to encompass the knowledge of all creatures which have appeared and been discovered by means of voyages on land and sea; and to know how they live and die, and all their customs and benefits, their circumstances and alterations [...]

Rifā'a al-Ṭahțāwī, $1833 .{ }^{373}$

But now the Great Map of Mankind is unrolld at once; and there is no state or Gradation of barbarism, and no mode of refinement which we have not at the same instant under our View.

Edmund Burke, 1777. ${ }^{374}$

\section{Introduction}

One of the major changes in consciousness brought about by the movement later known as the 'Nahda' was in Arab intellectuals' perception of their place, and that of their countries and societies, within the world. This is often reduced to the question of their changing relationship with Europe - with some justification, for it was with Europe that they had the most intense and sustained contacts, and through Europe that they initially derived much of their knowledge of the world beyond. But the abundant evidence for their knowledge of, and interest, in the non-European world outside their own lands requires, it seems to me, a restatement of the question. They needed to locate themselves within a new picture of the world, one dominated by Europe and often seen by them through European eyes, but not in

373 Introduction to Georges-Bernard Depping, Qalā'id al-mafākhir fì gharīb 'awā' id al-awā' 'il wa-l-awākhir (The Necklaces of Glories, on the Marvellous Customs of the Ancients and Moderns), trans. Rifā'a Rāfi' alṬahțāwī (Bulaq, 1833), 2: 2.

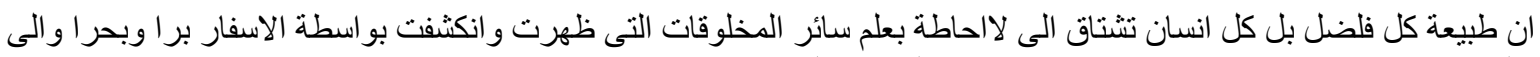

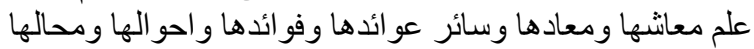

374 Letter to William Robertson, to congratulate him on the publication of his History of America, 9 June 1777: Selected Letters of Edmund Burke, ed. Harvey C. Mansfield (Chicago and London: University of Chicago Press, 1984), 102. 
fact reducible to the continent of Europe itself.

Nor is this a marginal point, for this diversity of the world beyond Europe was a crucial factor in forming that key concept of the Nahda which was analysed in Chapter 2: the idea of 'civilisation', with its perpetual counterpart, 'savagery' or 'barbarism'. In one of the Nahda's main sources, the European Enlightenment, this dichotomy was as much geographical as historical: not only the 'progress', through time, of civilisation out of barbarism (above all in Europe), but also Burke's 'Great Map of Mankind', showing every 'state' and 'Gradation' of barbarism and refinement, across the different parts of the world. ${ }^{375}$ The assumption that the world's societies could be 'placed' on this civilisational scale permeated European geographical knowledge; when the Arab intellectuals of the Nahda came into contact with it, they were concerned with 'placing' themselves in similar terms. An assertion that Syria or Egypt was, or could be, 'civilised' (mutamaddin), in the terms we have been examining, or that Bedouin or peasants were 'savage' (mutawahhish), placed these people and societies in relation, not only to Europe, but also to the other peoples held in Europe's scheme of the world: the Chinese, the American Indians, the Persians, the Hottentots. To that extent, even if knowledge of many of these peoples and places was, until the later nineteenth century, patchy and derivative from European sources, the fact that they were there was important.

This chapter will therefore investigate, not only the Nahda intellectuals' relationship with Europe, about which much has been written, but their place in the wider, Europeandominated world - a world changing and becoming more closely interconnected over the course of the nineteenth century. The sources for this investigation into how Nahda writers 'placed' themselves are various. In this chapter I will first consider the effect of European

375 See David N. Livingstone and Charles W. J. Withers, Geography and Enlightenment (Chicago and London: University of Chicago Press;, 1999), 14-15 and the sources cited. 
geographical knowledge on the first Arab writer to engage with it in a substantial way, Rifā'a al-Ṭahțāwī. I will look in detail at his translations and adaptations of early nineteenth-century French geography books into geographies of and for Mehmed Ali's state, by which Ṭahțāwī was employed. I will also suggest some contrasts between this new European-influenced geography and the existing, and rich, heritage of Arabic geographical writing (although it is difficult to say how much of this was known at the time). I will then deal in detail with the contrast between 'civilisation' and 'barbarism' described above, central to these European geography works as well as to much of the thinking of the Nahda, drawing on Tahțāwì's travel narrative Takhlīṣ al-ibrīz as well as his geographical translations. I will then pass more briefly in review other sources of geographical knowledge and geographical imagination in the mid-nineteenth century Egyptian and Syrian Nahda: geographies of the Ancient world and works dealing with great hero-figures, also mainly from translations of European works; and the foreign news reports of Hadīqat al-akhbār, mostly taken from European newspapers.

While this does not set out to be a comprehensive history of Arabic translations of European geographical works in the nineteenth century, a good deal of space is devoted to setting the historical and bibliographical record straight, presenting the sources and details of geographical and other writings of the Nahda. This may appear tedious at times, but is necessary in such a little-studied area. On these sources is then built an account of how Nahda intellectuals saw their own and their countries' place in the world. This account is inevitably partial and limited: I do not deal with the far better-known travel accounts by nineteenth-century Arab writers; my survey of the press is limited to some early numbers of Hadīqat al-akhbār. Works of imaginative literature also played an important role in the geographical imagination of the Nahda, but these will be considered in Chapter 4. In addition, this chapter has a somewhat polemical cast. This is directed against those scholars 
who have stressed the basic dependence on Europe of the Nahda intellectuals' worldview, their acceptance of European ideas and tropes. These scholars fall into two camps: those who regard this reliance on Europe in a more or less positive light - like Ibrahim Abu-Lughod, the first to write a major English study of the kind of material reviewed here ${ }^{376}$ - and those who see it in a negative light. This second category includes most of those Anglophone writers who have touched on these geographical materials since Abu-Lughod: the line of postcolonial critics which begins with Timothy Mitchell, and runs by way of Lisa Pollard to the recent work of Shaden Tageldin. ${ }^{377}$

It is with the second group that I mainly engage, in passing in the account of the various kinds of geographical writing, and in a more sustained manner in my conclusion. My attitude to them is far from wholly polemical, as I build in many places on their work. But I am concerned in the first place, as I have indicated above, to question the notion that Arab writers in this period were involved simply in a binary relationship with Europe (or 'the West'). In the second place, I am not convinced that their dependence on Europe, though undoubtedly strong, was as absolute and unqualified - at least in the period in question, the middle decades of the nineteenth century - as scholars such as Mitchell or Tageldin claim. And finally, I am concerned that the whole of this argument around ideological dependence on Europe, cultural imperialism, authenticity and the like, has been taking place in isolation from any detailed account of the economic, political and social formations to which Nahda intellectuals belonged: the kind of account sketched out in my first chapter. These questions will emerge as we proceed: for now, let us turn to the Arab writers and their work - and specifically, to begin with, that of Rifā'a al-Ṭahțāwī.

376 Ibrahim Abu-Lughod, The Arab Rediscovery of Europe: A Study in Cultural Encounters (London: Saqi, 2011).

377 Mitchell, Colonising Egypt; Lisa Pollard, Nurturing the Nation: The Family Politics of Modernizing, Colonizing, and Liberating Egypt, 1805-1923 (Berkeley: University of California Press, 2005); Shaden M. Tageldin, Disarming Words: Empire and the Seductions of Translation in Egypt (Berkeley: University of California Press, 2011). 


\section{Among the Geographers}

The attractions of European geographical writings, to an intellectual like Tahțāwī in the early nineteenth century, were various. He described two clear advantages in his introduction to Qalā'id al-mafākhir fì gharīb 'awā'id al-awà'il wa-l-awākhir (The Necklaces of Glories, on the Marvellous Customs of the Ancients and Moderns), his translation of Georges-Bernard Depping's Aperçu historique sur les mours et coutûmes des peuples, made during his stay in Paris in 1245/1829-30 and printed at Bulaq in 1249/1833. After the passage quoted above as an epigram, stating that everyone wished to gain 'the knowledge of all creatures which have appeared and been discovered', Țahțāwī continues:

It is clear that what is known to us is but a meagre quantity, especially in relation to distant countries, since we know only what was known to other people from ancient times. And perhaps knowledge of it came only from news and hearsay, not from witnessing and eyewitnessing. As for those countries the knowledge of which has appeared recently, like the country of America and the islands which are in the Pacific ocean, or those whose names were known but no their conditions, like the Frankish, Indian and Chinese countries and the Sudanese hinterlands, it [knowledge of them] requires explaining and making clear to us. So we had to search for it in its mines, and seek it in its treasuries and stores. And it has become famous among the elite and the commoners (al-khāss wa-l- 'amm) that the people of the Franks is now distinguished among peoples by trade and intercourse with other countries. Indeed, they have taken the knowledge of countries and their conditions as a means (sabab) and have selected elites (nukhab) for that. So their knowledge in geography (jughräfiy $\bar{a})$ and timekeeping ( $m \bar{\imath} q \bar{a} t)$ has expanded, and they are still increasing in sciences beyond other ages. So there is no way at this time to know the conditions of countries and creatures other than by transmitting them from those who have ascertained them among the Franks. ${ }^{378}$

378 Depping, Qalā'id al-mafākhir fì gharīb 'awā'id al-awā'il wa-l-awākhir (The Necklaces of Glories, on the Marvellous Customs of the Ancients and Moderns), 2: 2-3. My translation; for the use of the Egyptian colloquial word miqat, cf. Newman An Imam in Paris: Account of a Stay in France by an Egyptian Cleric, 1826-1831, trans. Daniel L. Newman (London: Saqi, 2004), 107, note 1.

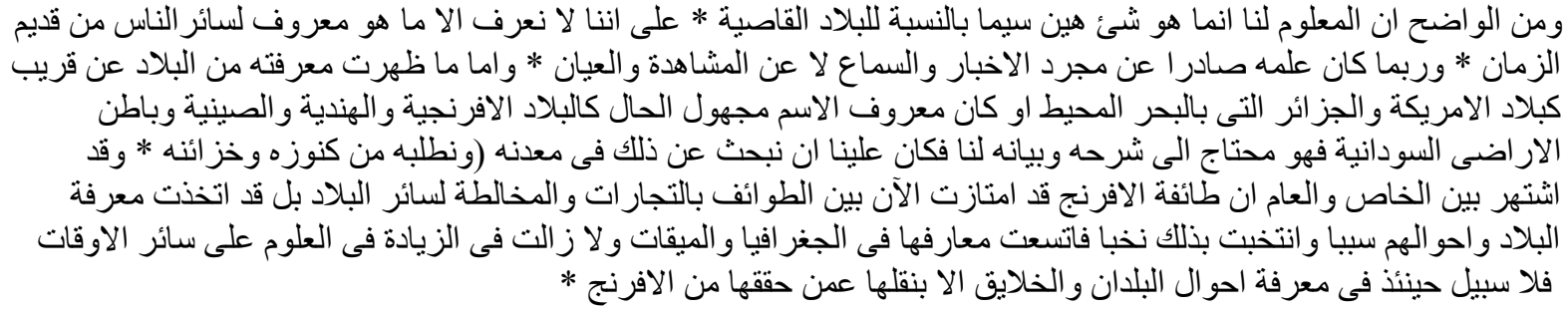

For the use of the Egyptian colloquial word mīqāt, cf. Newman, An Imam in Paris: 107, note 1. 
The two advantages of European geography books were, then, that they were up-to-date and based on first-hand accounts; and that they covered parts of the world which older geographies simply gave no account of: recently discovered America and the Pacific islands, but also Europe, India, China and southern Africa, previously known only by name. The Franks, by their 'trade and intercourse with other countries' and by their making a dedicated science of 'the knowledge of countries and their conditions', were uniquely qualified to offer this kind of knowledge. He had good reason to be acquainted with the efforts, particularly, of the French geographers: as he goes on to mention in this introduction, the man who had recommended Depping's book to him for translation was his teacher Edmé-François Jomard, the head of the school for the Egyptian scholarly missions in Paris, the editor of the Description de l'Egypte and a distinguished geographer in his own right. Geography was among the subjects studied by the missions in Paris: while there Tahțāwī translated into Arabic, in addition to Depping's Aperçu, Brard's Minéralogie populaire (Paris, 1826), an extract from Malte-Brun's Précis de géographie universelle, the introduction (on physical geography) to the Dictionnaire Universel de Géographie, an 'Introduction to Natural Geography in the edition by Monsieur [Alexander von] Humboldt', and 'a passage on cosmography'.379

The expertise of European geographers is perhaps still more sharply emphasized in his

379 Anne Godlewska, Geography Unbound: French Geographic Science from Cassini to Humboldt (Chicago and London: University of Chicago Press, 1999), 132-47 for Jomard; Mitchell, Colonising Egypt, reproduces the curriculum of the Egyptian scholarly mission to Paris: 73; An Imam in Paris, 290 and note 3; 299; 301 and notes 2 and 3. Newman identifies Humboldt's Natural Geography with al-Ta 'rībāt alshäfiya (299 n.3 and 43, n.3), but this seems to be erroneous. The work by Humboldt might have been either the Essai sur la géographie des plantes (an XIII/1805), or the Tableaux de la nature (1808): see C. (Carl) Bruhns and Robert Avé-Lallemant, Alexander von Humboldt. Eine wissenschaftliche biographie (Leipzig, F.A. Brockhaus, 1872), Section V: Bibliographische uebersicht. It is unclear exactly how these works relate to the 'geography textbook which comprised historical geography, physical geography, mathematical geography and political geography' and the 'treatise on natural geography in the form of an introduction to a geographical dictionary' which he refers to elsewhere in Takhlīs al-ibrīz. Newman (290, notes 2 and 3) identifies the second as the introduction to Malte-Brun's Dictionnaire géographique portatif, which seems plausible; this was probably the same as the Dictionnaire Universel de Géographie (300). The first is likely to be Malte-Brun's Géographie universelle, which divides the discipline up in a similar way to that which Țahțāwī describes. 
introduction to another translated geography book, the following year:

I had to hand no geography book in Arabic, which contained detail and organisation in the manner of what is in the Frankish books. For this reason I decided upon a book that summarises this valuable art, written for the schools of the principles of knowledge [presumably: primary schools] in the city of Paris, and I began to translate it lesson by lesson to this end $[\ldots . .]^{380}$

Here he mentions not the coverage of all parts of the world, nor eyewitness reports, but 'detail and organisation': precise information, and the method developed by French geographers of laying out the essential facts about the countries of the world, in this case for pupils of primary schools. The point is particularly relevant in the case of this work, which Ṭahțāwī dubbed al-Ta 'rībāt al-shāfiya li-murīd al-jughrāfiyā (Salutary Arabizations for the Seeker of Geography). Depping's book, the basis for Qalā'id al-mafākhir, was not a geography as such, but a work of proto-ethnography, on the 'manners and customs' of the peoples of the world. Though its main theme - the different degrees of civilisation and barbarism found among various peoples - is present throughout as a kind of organising principle, its structure can appear somewhat haphazard, as chapters on ‘women' or 'superstition' succeed those on diverse kinds of 'dwelling' and 'dress'. The principal source for al-Ta 'rībāt al-shāfiya, however - the French primary-school textbook to which Țahțāwī's introduction refers, though he nowhere names it - was the Nouvelle géographie méthodique of Achille Meissas and Auguste Michelot. ${ }^{381}$ This set out, as its title proclaims, to condense the work of eminent French geographers (such as Malte-Brun and Jomard himself) into a concise and methodically-organised form. It became a standard French school textbook in geography. ${ }^{382}$

380 Rifā'a Rāfi‘ Țahțāwī, al-Ta 'rībāt al-Shāfiya li-Murīd al-Jughrāfiyāa (Bulaq: Dār al-Maṭba'a alKhudaywiyya, 1250), 1: 3 . The textbook was reprinted in 1254/1838.

وليس بيدى من كتب الجغر افيا شئ باللغة العربية * يحتوى على التفصيل و الترتيب على نسق مئ ما في الكتب الافرنجية فلهذا اعتمدت

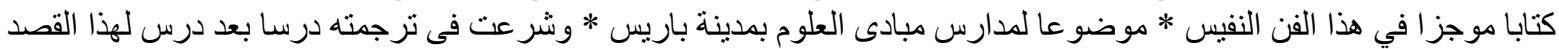

381 Achille Meissas and Jean Charles Auguste Michelot, Nouvelle géographie méthodique (Paris: Hachette, 1835).

382 The same textbook later appeared in Ottoman Turkish translation: Achille Meissas and Jean Charles Auguste Michelot, Risale-i coğrafya, trans. Bogos Tiryakioğlu (Istanbul: s.n., 1849). 
It also broke with the then-common fashion of writing elementary textbooks in the form of catechisms. This model had been followed in another geography textbook which Ṭahțāwi prepared for the Bulaq press, and which was printed in the same year as al-Ta'rībāt alshāfiya: Kitāb al-Kanz al-mukhtār fì kashf al-arạ̄̂̄ wa-al-biḥ̄àr (The Chosen Treasure, on Revealing Lands and Seas). ${ }^{383}$ This was a revision of a textbook printed by the Protestant missionaries at Malta the previous year. This work, Geoffrey Roper informs us, was based on the geography section of James Mitchell's Universal catechist [London 1824, pp. 152-206], with some additions from other sources, including William Channing Woodbridge's Rudiments of geography, London 1828, mainly relating to Middle Eastern countries [...]. It had been translated into somewhat unidiomatic Arabic, probably by [Christoph] Schlienz and ['İsā] Rassām, and it presents a quite Eurocentric view of world geography. ${ }^{384}$

Ṭahțāwî̀s changes, Roper notes, were limited mainly to Arabic style (to correct it from its 'barbarous Maltese mode of expression'), though there were also some changes which reflect his status as an (educational) functionary of Mehmed Ali’s state: 'Information about the Artillery School [at which Ṭahțāwī was then working], and the subjects studied there, is also inserted in pride of place in the section relating to education in Egypt. ${ }^{385}$ The same textbook continued to be used in both the Egyptian and the missionary schools: in 1836 a third edition was printed at Malta, with further revisions made by Fāris al-Shidyāq; and as late as 1871 , under Ismail, a Mukhtașar jughräfiyya prepared for the military schools was largely based on it (though the order of continents was altered: Africa, Asia, Europe, America, Oceania). ${ }^{386}$

But the Bulaq edition of al-Kanz al-mukhtār was perhaps intended by Ṭahṭāwī as a stop-gap

\footnotetext{
383 Rifā'a Rāfi' Țahțāwī, ed., Kitāb al-Kanz al-Mukhtār fì Kashf al-Arāộ̄ wa-l-Bihāàr, 2nd ed. (Bulaq: Mața'at Maktab al-Ṭūbjīyah, 1250).

384 Geoffrey Roper, 'Arabic Printing in Malta 1825-1845: Its History and Its Place in the Development of Print Culture in the Arab Middle East.' (University of Durham, 1988), 248. 385 Ibid., 248-9.

386 Ibrāhīm al-Disūqī, Mukhtașar Jughrāfiyya (Bulaq: al-Mațba‘a al-Khudaywiyya, 1290).
} 
measure, and in any case only aimed at a basic level of instruction in geography. ${ }^{387} \mathrm{Al}$ -

Ta 'rībāt al-shäfiya aspired to greater detail and sophistication, and was to a far greater extent the work of Tahțāwī himself - in his role as a loyal servant of Mehmed Ali's dynasty. His main interventions in the text of Qala 'id al-mafäkhir had been to add a glossary of unfamiliar terms - a common feature of the Bulaq translations, though this one was particularly extensive - and to suppress 'all the statements that are derogatory and defamatory of Islamic customs or what is useless and of no benefit whatsoever. ${ }^{, 388}$ With alTa 'rībāt al-shäfiya he intervened in a far more substantial fashion as editor-compiler, and this seems to have been prompted by deficiencies he perceived in Michelot and Meissas's textbook. After stating, in the passage from his introduction cited above, that, impressed by the 'detail and organisation' of this work, he had begun 'translating it lesson by lesson', Ṭahțāwī continues:

When I saw that its author was more verbose on Europe, since it is his homeland, and more concise on other [parts of the world], which are not his house or home, so in this way it was not sufficient for us, and would not quench the ardent thirst of those who looked into it. And I had perused other books on the geographical sciences, applied myself to them, and took them into the best consideration during my stay in the kingdom of the French, I wished to complete [these] aims by summarising what was suitable to the occasion, so that there should be equivalence and balance, proportion and parallel, and that by this the usefulness of this root and branch [i.e. of this science] might be made complete. So there came, by the aid of Him who is exalted, a great occurrence in this art, containing a summary of its lengthy books, accepted by the most acceptable of minds, and the most polished of intellects, the possessor of a virtuous soul, and a perfect and lofty intent [presumably his patron Mehmed Ali]. And I named it the Salutary Arabizations for the Seeker of Geography [al-Ta 'rībāt al-shāfiya li-murīd al-jughrāfiyā.$^{389}$

In other words, Ṭahțāwī has noted the Eurocentric bias of Michelot and Meissas's work, and

387 This is suggested by the fact that Țahțāwī refers the reader to both Qalä 'id al-mafākhir and al-Ta 'rībāt alshäfiya for further information, in his epilogue to al-Kanz al-mukhtār: 143.

388 Qalā'id al-mafākhir fì gharīb 'awā'id al-awā'il wa-l-awākhir (The Necklaces of Glories, on the Marvellous Customs of the Ancients and Moderns), 3; translation from Youssef Choueiri, Modern Arab Historiography: Historical Discourse and the Nation-State (London: Routledge, 2003), 5.

389 Al-Ta'rībāt al-Shäfiya, 1: 3.

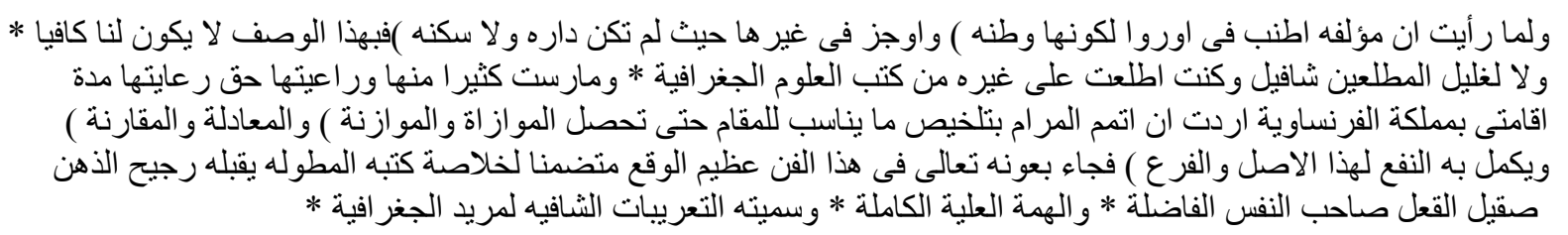


set out to remedy it, 'so that there should be equivalence and balance', by drawing on other geographical works. ${ }^{390}$ But other European works, which he had read 'during my stay in the kingdom of the French'. A similar procedure had been followed, presumably, by the original missionary translators of Mitchell's Universal catechist, with their 'additions from other sources $[\ldots]$ mainly relating to Middle Eastern countries [...]' (although Roper does not tell us exactly what 'Middle Eastern' countries this includes). Ṭahțāwī, in composing al-Ta 'rībāt al-shäfiya, thus follows a process of what European Renaissance rhetoric would have called contaminatio - the blending and creative adaptation of two or more different sources into one's own text. It is a technique also, of course, of the adab tradition in which Ṭahțāwī was trained; there are places in his other writings where he makes similar use of Classical Arabic authors. ${ }^{391}$ But here he uses these skills to emend - and, as we shall see, occasionally to contest - his main European sources, by means of other European sources.

Ṭahțāwī does not name the other geography books he uses, any more than he names Meissas and Michelot's work. The only source he does mention, in his second introduction (muqaddima), is a memorandum written by Jomard:

We have put into this book what circumstances require of the strength of states and kings, and their yearly revenue. In this we have based ourselves on a memorandum [or letter: risāla] written by the Khawäja Jomard, one of the chief men of the great school in the city of Paris. He is the cause of our applying ourselves to this science [of geography]; from the time of our parting until now he supplies us by correspondence with new benefits of this art $[\ldots .]^{392}$

390 Michelot and Meissas's textbook is in fact not only Eurocentric but Francocentric: in the 16th edition (1835), 163 of a total of 273 pages in the sections on physical and political geography are devoted to Europe, and only 110 to the rest of the world; moreover, of these 163, 75 (a little under half) are devoted to France alone. France receives a more detailed description than any other country (by départements) in the political section, and its own dedicated part of the physical section.

391 E.g. his insertion of an extract from Miskawayh into Manāhij al-albāb: see Hosny, 'Tradition et Renouveau Dans L'oeuvre de Tahtawi', 86.

392 Ṭahțāwī, Al-Ta 'rībāt al-Shāfiya, 1: 5.

وقد ادخلنا فى هذا الكتاب ما بحتاج اليه من قوة الدول و الملوك و اير ادهم السنوى و اعتمدنا فيه على رسالة الفها الخو اجه جومار احد

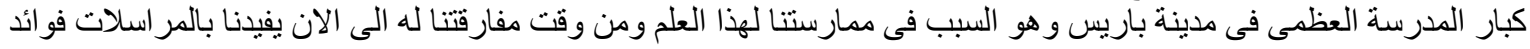
جديدة من هذا الفن الندار

I do not know whether any of this correspondence between Tahțāwī and Jomard survives. A letter sent to him by the French orientalist Reinaud, however, enquiring about his translation of Depping and informing him of a new edition of Malte-Brun, is reproduced in Takhlīs al-ibrīz: Newman, An Imam in Paris, 286-7. 
This information of Jomard's was presumably the basis for Tahțāwī's addition, at the end of sections derived from Michelot and Meissas, of figures for the military strength (quwwāt 'askariyya) and annual revenue (ìrādàt sanawiyya) of most countries.

But the main source for his additions to the base text of Meissas and Michelot was the Précis de la géographie universelle (1810-29) by Conrad Malte-Brun (1775-1826), a Dane who settled in France in 1799. Tahțāwī had studied and translated an extract from this work while in France; he was later to undertake a complete translation, of which, however, only Volumes 1 and 3 seem to have been printed (see below). The Précis, which runs into eight to twelve volumes in its different editions, is a much fuller work than Meissas and Michelot's textbook, for which it served as one of the sources. It was, as Anne Marie Claire Godlewska informs us, a deliberate revival of the tradition of universal geography, which goes back to the Ancient Greek Stoic Strabo. Compared to its predecessors, it is impressive in 'scope, ambition, and erudition'. Malte-Brun carefully cited his sources, in several European and Classical languages, across a broad range of topics:

He maintained a critical and thoughtful approach to the research that he reviewed. [...] His descriptions were lively and entertainingly written and some of his characterizations of governments and peoples were strikingly prescient. It was a remarkable effort [...].

But he was hostile to the cartographic tradition in geography, which regarded the map as the basis of the discipline; he was hostile, too, to generalising and speculative theories of geography. 'Rather, his conception of geography was vague, based on an attachment to the field's long-standing affiliation with history and the humanities, and hostile to the very foundations of modern science and social science.' In particular, he sought to 'protect physical geography' from the new geological theories 'on the origin and evolution of the earth'. This led to a somewhat uncomfortable marriage between physical and human 
geography: physical features, though prominent, are subordinated 'to the conventional political-regional structure' of the Précis. ${ }^{393}$

\section{The Old Geography and the New}

And here we should take a step back from the textual detail of Tahṭāwī’s translations and compilations, and consider some of the wider implications of this enterprise. We can understand the appeal of the European geographers - on the various grounds that Tahțāwi cites, of worldwide coverage, eyewitness and up-to-date information, organisation and detail - if we consider the difficulties he would have faced, if he had set about trying to compile a world geography from the existing resources of the Arabic geographical traditions. These were, of course, rich: al-Khwārazmī’s (d. 236/850) Șürat al-arḍ, with its version of the Ptolemaic system; discursive $a d a b$ works full of geographical detail, like al-Mas 'ūd̄̄’s (d. after 345/956) Murūj al-dhahab; Yāqūt's (d. 626 /1229) Mu 'jam al-buldān (to which Ṭahțāwī in Takhlīṣ al-ibrīz compared Malte-Brun’s Dictionnaire géographique portatif); the travel narratives of Ibn Jubayr (d. 614/1217) and Ibn Baț̣uṭa (travelled 725-54/1325-53), to mention only two; Maqrīzī’s (d. 845/1442) great Egyptian geography; and continuations of the tradition down to Ṭahtāî̄'s own day, such as Christian travellers to Europe, or alGhazzāl, the Moroccan traveller to Spain (d. 1191/1777). ${ }^{394}$

But not all of this immense heritage would necessarily have been available to even the bestequipped Egyptian scholar in the early nineteenth century. It is difficult to offer more than guesswork on this point without more detailed studies than yet exist of the Egyptian

393 Godlewska, Geography Unbound, 89-109; Lisa Pollard noted this same feature, accusing Malte-Brun of collapsing 'science' into 'subjectivity': Nurturing the Nation, 29-30, and notes 53 and 54. This is part of a larger argument about 'positivist' European knowledge, which will be discussed in the Conclusion.

394 For a summary account, see L. Richter-Bernburg, 'Geographical Literature', ed. Julie Scott Meisami and Paul Starkey, Encyclopedia of Arabic Literature (London and New York: Routledge, 1998). The most comprehensive study is still Kratchkovsky's: Tārīkh al-adab al-jughrāfì al- 'Arabī (History of Arabic Geographical Literature), trans. Șālāḥ al-Dīn 'Uthmān Hāshim, 2 vols. (Cairo: Lajnat al-Ta'līf wa-alTarjamah wa-al-Nashr, 1963). For Tahtawi's comparison, see An Imam in Paris, 290 and notes 3 and 4. 
intellectual 'scene' of the late eighteenth and early nineteenth centuries. Were geography or related disciplines taught in the Azhar or other schools? What works were held in their libraries? Such questions remain unanswered. But Kratchkovsky suggests that we can get a sense of the state of the geographical knowledge available to learned circles in Egypt at the end of the eighteenth century from al-Zabīdī's monumental dictionary Tāj al- 'ārūs.

Geographical sources he mentions are Yāqūt's Mu jam al-buldān (of which only three volumes were available to him), and a number of 'regional' geographies, focussed on Egypt, from a later period: Majīr al-Dīn's (d. 928/1522) al-Uns al-jalīl, Ibn Mamātī (d. 605/1209) and Ibn Jī'ān (d. 902/1497), and of course Maqrīzī. Kratchkovsky’s conclusion, which seems reasonable, was that to the eighteenth-century $a d \bar{\imath} b$ in Egypt, much of the older geographical tradition had been forgotten, and newer additions, such as travel narratives, had not yet become known. ${ }^{395}$

But then, Zabīdī was not a geographer; we may surmise that more works in the Classical tradition of geography, if not more recent ones, might have been available to a scholar who was prepared to spend more time on specialist research. But even so, consider their limitations, many of which Ṭahțāwī points out in his introduction to Qalā'id al-mafäkhir. They contained not only no America and no Pacific, but only hearsay knowledge of most of Europe. (The recent accounts by authors, many of them Christian, who had travelled to Europe, were unlikely to have been available to Ṭahțāwī; that of the Chaldean priest Ilyās alMawșilī, who went as far as South America, apparently remained in a Church library in Aleppo until the twentieth century; the Arabic narrative, written in 1831, of the West African slave 'Umar b. Sa 'īd, transported to America in 1807, was not rediscovered until 1995. ${ }^{396}$ )

395 Kratchkovsky, Tārīkh al-adab al-jughrāfì al- 'Arabī (History of Arabic Geographical Literature), 2: 775. 396 Ami Ayalon, 'The Arab Discovery of America in the Nineteenth Century', Middle Eastern Studies 20, no. 4 (1984): 5-17; Ghada Osman and Camille F. Forbes, 'Representing the West in the Arabic Language: The Slave Narrative of Omar Ibn Said', Journal of Islamic Studies 15, no. 3 (2004): 331-43. 
Their knowledge of even the Islamic lands, India and China, was several centuries old. Apart from more recent ages, there were whole epochs of the past which were unknown to them, and which Europeans had now begun to open up (think of Maqrīzī's account of the Ancient Egyptian monuments). Their cosmography was Ptolemaic, undisturbed by Copernicus or Newton, let alone by modern geological theories. ${ }^{397}$

Then there is their organisation: the episodic, sometimes fragmentary travel accounts, the ‘idiosyncratic, adab-like prolix works’ (Richter-Bernburg's expression) of al-Mas 'ūdī. Maqrīzī's geography of Egypt is ordered by physical locations (Egypt in general, the Nile, Alexandria, Cairo, Cairo's castles and gates, etc.), but with much variation and considerable digressions (e.g. into the history of Alexander the Great, under Alexandria; the organisation of diwans and law-courts, under the halls of Cairo Citadel). ${ }^{398}$

It is true that Depping's Aperçu can seem almost as genially haphazard as a work in the adab mode: Țahțāwī may well have drawn on it, as well as on Arabic travel-narratives and the $a d a b$ tradition, for the organisation of Takhlīs al-ibrīz. But Michelot and Meissas's Nouvelle géographie méthodique lives up to its name. It is divided into three sections, the first giving elementary information, the second more advanced details, and the third the principles of physical geography, cosmography, and the construction of maps (the last-mentioned section contributed by a M. Charle). Within these, the whole work is divided into numbered parts, ranging in length from a sentence to a few pages (445 in total, in the 1835 edition): these perhaps were the 'lessons' (dars) Țahțāwī refers to in his introduction. In the largest (second) section, each 'country' (contrée) is dealt with in standardised format: 1. population and

397 As we have seen in the case of Malte-Brun, the latter were widely in dispute in the early nineteenth century. American geography primers of the period (including Channing Woodbridge's, which was one of the sources for al-Kanz al-mukhtär) adhered to a religious version of the history of the earth: see Albert M. Craig, Civilization and Enlightenment: The Early Thought of Fukuzawa Yukichi (Cambridge, MA: Harvard University Press, 2009), Chapter 1.

398 Aḥmad ibn 'Alī Maqrīzī, Kitāb al-Mawā iz wa-al-i tibār bi-dhikr al-khiṭaṭ wa-al-āthār (Būlāq: Dār alṬibā'a al-Mișriyya, 1270). 
surface area (i.e. two numbers), 2. short historical notice, 3. general description, 4.

administrative divisions, 5. remarkable towns and places, 6 . additions to the information on physical geography given in the first section. ${ }^{399}$

As scholars influenced by Foucault such as Timothy Mitchell have emphasized, there is an exceptional impression of openness about such a work, of information laid out easily before the reader's eyes, which is lacking in the digressive narrative or descriptive accounts of Arab travellers and geographers. If knowledge in the latter had sometimes to be searched for among twisting alleyways like those Malte-Brun criticised in the city of Cairo, Michelot and Meissas's book is as well-ordered and palpably accessible as the grid-plan of a modern European city. This, with its numbered sections, its standardisation, its statistics, gives an impression not only of method but of unassailable objective truth. And Tahțāwī’s comment on the 'organisation' of European geographies in his introduction suggests that this was not unwelcome: indeed, he added one other element to it in a similar standardised and statistical mode - Jomard's information on revenues and military strength. Tartīb, organisation, was as Mitchell has pointed out one of the key words of Mehmed Ali's administration, used to express the new, rational, systematic ordering of several different areas of government. ${ }^{400}$ But other alterations and enlargements he made to Michelot and Meissas's scheme, drawing in particular on Malte-Brun's Géographie universelle - a work similarly systematic in conception but less rigid in execution - suggest a slightly different set of priorities. As we shall see, some of the lacunae, the defects, the questionable statements concealed beneath the apparently open and objective surface of Michelot and Meissas's textbook are noted, and steps are taken to remedy them.

399 Meissas and Michelot, Nouvelle géographie méthodique, 'Avertissement', ii.

400 Colonising Egypt, 88-9. I am less convinced by his account of its replacement by 'tarbiya', or the suggestion that this term only gained its meanings associated with 'education' during the nineteenth century: it is well-attested in the sense of 'upbringing' in the Classical dictionaries used by Lane, for instance. 
The Arabic geographical tradition did not die out in the nineteenth century: an edition of Maqrīzī’s al-Mawā 'iz wa-al-i 'tibār (known as al-Khițat al-Maqrīziyya) was printed at Bulaq in 1853, and Ali Pasha Mubarak wrote his al-Khițat al-Tawfiqiyya (Bulaq, 1304-6/1886-9) in much the same tradition. Tahțāwī was obviously aware of its existence - in his 'Introduction to Geography' (the second introduction to al-Ta 'rìbāt al-shāfiya), he states that although the 'Islamic scholars' (al- 'ulama $\bar{a}$ ' al-islāmiyyūn) did not often use the term jughrāfiyā, they expressed the same meaning under 'the science of registering countries or of mapping regions' ('ilm taqwīm al-buldān aw fann takhțịt al-aqālìm: it is perhaps of interest that he refers here to the most systematically organised and the most visually open parts of the Islamic tradition: the dictionaries and maps of countries). ${ }^{401}$ The travel narratives of the Nahda period, including Țahțāwì's, can be seen as continuing the lineage of Ibn Bațtūta. But as a means to knowledge of the world in general - if only a shortcut, a temporary measure these European textbooks were, in the 1830 s, irresistible. And irresistible especially to someone in Ṭahtāwầ’s position, who was making his entire career out of his specialised knowledge of European languages and European learning.

\section{'A picture of what his rule contained': a geography of Mehmed Ali's domains}

Nor was the appropriation of European geographical knowledge only a matter of abstract learning, taking place in the heads of intellectuals. In what is probably the fullest account of the geographical translations in English since Abu-Lughod, Lisa Pollard points out, in a footnote: 'Geography as the very concrete practice of studying the surface of Egypt was also crucial to many of Mohammad 'Ali's modernization programs, such as the construction of

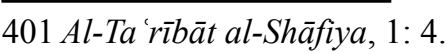


railroads, telegraphs, and irrigation canals. Here I am interested in geography as the more abstract practice of ordering the universe. As Winichakul has suggested [in Siam Mapped], this "abstract" geography becomes more concrete when maps are used to give boundaries to nations once they have been "placed." ${ }^{402}$ But I am not sure that we can separate so neatly as this the practical aspects of geography as employed by Mehmed Ali's state, and 'geography as the more abstract practice of ordering the universe': nor is it immediately apparent that the latter is the more worthy of attention. It is true that Țahțāwi sometimes writes in a way that suggests that he is thinking of geography in terms of pure knowledge: 'The nature of every virtuous person, yea of every human being, longs to encompass the knowledge of all creatures which have appeared and been discovered [...]' he wrote in his introduction to Qalā 'id al-mafākhir. But though trained in institutions of a 'disinterested' scholastic learning, he was now a servant of Mehmed Ali's state, and the geography textbooks he produced were destined for the military and bureaucratic schools. Alongside the introduction to Qalā'id al-mafäkhir we have to place that to al-Ta'rībät al-shäfiya, where he states that he has produced this book specifically for the Jihadiyya's new programme in history and geography teaching. ${ }^{403}$ The officers and officials who followed this programme were not being trained to abstractly order the universe, but to conquer and govern specific parts of the Near Eastern world. It may be worth recalling a few dates. Mehmed Ali had had troops in the Hijaz since 1811, fighting the Wahhabis; his son Ibrahim had campaigned against the Greek rebels in the Morea from 1824 to 1828 ; from 1830 to 1840 his forces held the island of Crete. In 1833, the year Qalā'id al-mafākhir was published at Bulaq, Ibrahim was installed as governor of Syria after the successful campaigns of the previous year; he held it until 1841. In 1833, too, Mehmed Ali dispatched another expeditionary force to Mocha in the Yemen; by 1838 he held the whole Red Sea coast of Arabia. In 1838 the Pasha personally

402 Nurturing the Nation, 220, n. 46. 403 Al-Ta 'rībāt al-Shāfiya, 1: 3. 
visited the 'Egyptian' Sudan, which his troops had first invaded in $1820 .{ }^{404}$

In other words, the publication of Ṭahțāwī’s translated geography books coincided with the years of Mehmed Ali's greatest success in military empire-building, before the 1840 treaty forced on him by Britain stripped him of all possessions outside Egypt except the Sudan. This may go some way towards explaining the urgency evident in the production of Qala 'id al-mafākhir, al-Kanz al-mukhtār, al-Ta 'rībāt al-shāfiya, and the first volume of alJughräfìya al- 'umūmīya on each other's heels, in 1833-5.

There is also the matter of Țahțāwī’s personal career. On his return to Egypt from the mission to France, in 1831, he was employed as a translator and French teacher at the School of Medicine: his translations of Brard's Minéralogie populaire and of Depping's Aperçu appeared in 1832 and 1833, and his revision of a translation of a French veterinary manual in 1833. This same year, he became chief translator at the military school at Tura, where he had a difficult relationship with the school's head, Don Antonio de Seguerra Bey. In 1834 Takhlīṣ al-ibrīz, his revised edition of al-Kanz al-mukhtār, and al-Ta 'rībāt al-shāfiya appeared, and he completed a manuscript Risāla fì jughräfiyā bilād al-Shām (Treatise on the Geography of Bilād al-Shām). In 1835, after a period in his native Tahțā to avoid the plague in Cairo, he presented his translation of the first volume of al-Jughräfìya al- 'umūmīya to Mehmed Ali he received 'a generous financial emolument, alongside a promotion to the military rank of șăghaqūl aghāsì (adjutant-major). The same year, he set up the Language School (Madrasat al-alsun) in Ezbekiyya, which grew considerably over the next decade; he was promoted to lieutenant-colonel and, on completing the third volume of al-Jughräfìya al-umūmìya in 1844, to amīr alāy al-rafí 'a (colonel), which brought with it the title of 'Bey'. ${ }^{405}$

404 Ibrahim, 'The Egyptian Empire, 1805-1885'.

405 Rifā'a al-Ṭahtāwī, An Imam in Paris, 38-51; the Treatise on the Geography of Syria is now in Dar alKutub in Cairo: a page and a map from it are reproduced in Hosny, 'Tradition et Renouveau Dans L'oeuvre 
From this it appears that he was building a career around his expertise in translation - where, indeed, he excelled all his rivals - but within this, around a specialisation in geography.

Behind this may have lain, to some extent, the influence of Jomard ('every inch a geographer', according to Godlewska); but the Egyptian demand for geography, the need of Mehmed Ali's officials for knowledge of the countries they were going forth to subdue, to govern, to negotiate with, seems likely to have been the major factor. ${ }^{406}$

The imperial nature of Mehmed Ali's state in these years, the connection of this with geographical knowledge, and Ṭahțāwī’s specialisation in just this discipline, seems to call for a reconsideration of the place of Țahțāwī and the Language School within the Egyptian state. It is often noted that the majority of the actual 'translation movement' under Mehmed Ali was directed to thoroughly 'utilitarian' or 'practical' subjects: military, engineering and medical manuals. The 'humanistic' knowledge which was Ṭahțāwī's particular province is sometimes seen as somehow exempt from this, a minor part of the whole project perhaps, but a largely independent one, driven by more disinterested, or at least more abstract motives. But while there is clearly a difference between a geography or history book, and a manual of gunnery, I am not sure that this kind of division accurately grasps the nature of Mehmed Ali's project. On the one hand, the two kinds of knowledge were bound up with each other in practice: Țahțāwī served in the Artillery School as well as the School of Languages; his textbooks were explicitly designed for use in the schools for officials and

de Tahtawi'. Only Volumes 1 and 3 of al-Jughräfı̀ya al- 'umūmīya seem to be extant: Shayyāl gives the dates as 'before 1251' and 'before 1262' respectively, but if Newman's account of the presentations to Mehmed Ali is correct, they appear to have been 1835 and 1838. As for the missing volumes, it seems odd that the second at least was never produced, but the history of the Bulaq translation project is full of unrealised schemes and unsubstantiated claims of translations made; see Jamāl al-Dīn Shayyāl, Tārīkh alTarjama wa-l-haraka al-Thaqāfiyya fi 'așr Muhammad 'Alī (History of Translation and the Cultural Movement in the Age of Muhammad Ali) (Cairo: Dār al-Fikr al-'Arabī, 1951), Appendix 1, no. 29, and Appendix 4. 406 Godlewska, Geography Unbound, 134. 
officers, alongside military and engineering manuals. On the other hand, 'humanistic'

knowledge could serve the state and dynasty as well as 'utilitarian' or technical knowledge.

These preoccupations become evident when we return to the detail of the text of al-Ta 'rībāt al-shäfiya. In the second of Ṭahțāwī's two introductions to this work - both plentifully larded, as is the case for most books printed at Mehmed Ali's presses, with praises of the ruler - we find, inserted into a potted history of the geographical discipline, the following passage:

The first map in the world was drawn by King Sesostris or Sisāa, the first of the kings of Egypt. He conquered the country and made subject to himself the rulers of India and Yemen, and he wished to make plain to the people of Egypt the greatness of his rule and the extent of his dominion. So he drew for them a picture of what his rule contained $[\ldots . .]^{407}$

The thought is not, perhaps, wholly irrelevant to the project of al-Ta' rībāt al-shäfiya. When we examine the alterations that Țahțāwī has made to the coverage of Meissas and Michelot's Nouvelle géographie méthodique, we find that - apart from the addition of Jomard's figures for revenue and military strength - these are almost entirely in the regions in which Mehmed Ali's forces were engaged. Tahtậwī states in a note on the section on Syria:

Since this eyalet is neighbouring to Egypt, and there is between them a kinship, a union and a proximity, we must explain them further and in general. So we should clarify in this book of ours the land of Egypt, Nubia, the Sudan, the provinces of the Hijaz and Bilād al-Shām more [extensively] than other countries, since they have been numbered among [lit: strung on the thread of] the Egyptian countries. But we will mention each region in its place. ${ }^{408}$

This then is the rationale: 'Egypt, Nubia, the Sudan, the countries of the Hijaz and Bilād al-

407 Al-Ta'rībāt al-Shāfiya, 1: 5.

$$
\begin{aligned}
& \text { و اول خرطة فى الدنيا هى الخرطة التى رسمها الملك سيستريس او سيساق وهو اول ملك من ملوك مصر فتح البلاد وخضعت له } \\
& \text { سلاطين الهند و اليمن فار اد ان بيين لاهل مصر الئ عظم ملكه و اتساع حكمه فرسم لهم صورة مل ما احتوى ملكه عليه }
\end{aligned}
$$

The history of geography states that the science reputedly began with 'Hermes al-hakīm' in Egypt. 408 Ibid., 1: 147-8.

$$
\begin{aligned}
& \text { من حيث هذه الايلة بجو ار مصر وبينهما مناسبة واتحاد ومجاورة وجب علينا زيادة بيانها وبالجملة فينبغى ان نوضح في كتابنا هذا }
\end{aligned}
$$

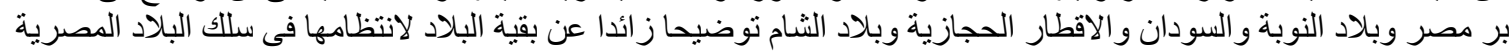

$$
\begin{aligned}
& \text { ولكن نذكر كل اقليم فى محله }
\end{aligned}
$$


Shām' are now 'the Egyptian countries', and ought to be dealt with in more detail (although Ṭahțāwī continues to adhere to Michelot and Meissas's original order: 'each region in its place'). This then is how Ṭahțāwī proceeds in combining his two main texts. He retains the general organisation, numbered sections and all, of Meissas and Michelot's textbook. Their first and third sections, on physical geography and geographical theory (including the construction of maps) he reproduces more or less exactly - with one exception which we shall consider below. The same goes for those parts of the main, second section (a detailed human geography of all the 'contrées' of the world), which deal with Europe and the majority of the non-European world. But for Egypt, Arabia, and Bilād al-Shām, and also for the Asian provinces of the Ottoman Empire, Țahțāw⿳亠丷厂s description is made up mainly of sections translated from Malte-Brun's Précis. These he continues to divide up mainly according to the headings (Notions historiques, Description générale, Villes et lieux remarquables, Additions à la géographie physique) of Meissas and Michelot, maintaining a consistency, in terms of organisation, with the rest of the text. Within this structure he often inserts, however, sections under different headings, derived from Malte-Brun or elsewhere. He also gives, after the main section from Malte-Brun, a 'summary', which consists in fact of the main general remarks (Notions historiques, Description générale, etc.) from Meissas and Michelot (in one instance, for Arabia, he apologises for the repetition of information which this entails). And as for most countries throughout the work, he adds at the end of each country's section Jomard's estimates of 'Military strength and yearly revenue'. ${ }^{409}$

In addition to these main 'Egyptian countries'- Egypt, Bilād al-Shām, and Arabia - he also adds individual sections on all the Asian eyalets of the Ottoman Empire, rather like those for the French départements in Meissas and Michelot's textbook. (I have not found the source of these additions, which do not seem to be from Malte-Brun.) The section on Greece is also 409 Ibid., passim. Arabia: 1: 134. 
rearranged, as we shall see. The North African lands of Algiers, Tunis, and Tripoli (listed under Meissas and Michelot's heading of 'Barbarie', translated as Ard al-barbar) are given a brief addition note clarifying their relationship to the Ottoman Empire. Despite his claim in the note to the 'Bilād al-Shām' section cited above, Nubia and the Sudan do not receive major additions: the Sudanese section, under the heading Bilād al-sūdān aw al-zunüj, is a close translation of Meissas and Michelot's section on 'La Nigritie', with a note on the name and the addition of figures for revenue and military strength. Nubia receives the same treatment, with the addition of some extra information on its administrative divisions. They, like the other non-European lands, including Muslim ones ('Independent Tartary', Persia, Afghanistan, Baluchistan, and the Muslim parts of India), are left with little more than the brief descriptions of Meissas and Michelot. ${ }^{410}$

Of the sections he takes from Malte-Brun, however, he does not everywhere follow the Danish geographer's text, but makes cuts and insertions quite freely. Certain differences between the preoccupations of the writer of the French original and his Egyptian adaptor become evident. In some of these the concerns of realpolitik and military affairs take priority over Malte-Brun's 'humanistic' digressions. Ṭahțāwī cuts a long passage on the supposed ancient origins of the Druzes of Mount Lebanon, and instead inserts more obvious points from their history, including important information such as the fact that they are supposed to be tributary to the Ottomans (kharäjiyyīn).

In the immediately preceding passage on the Maronites, Ṭahțāwī had inserted important information, not present in Malte-Brun's text: that the Maronites are under the protection of the Druze emir and pay the Ottoman kharäj; details of their political organisation under village sheikhs; a fuller account of their origin than in Malte-Brun; and accounts of the 410 Ibid., 1: 209 ('Barbarie'), 1: 244-8; Nouvelle géographie méthodique, 229-33 ('Nigritie' and 'Nubie'). 
attempts of Ottoman Sultans Selim and Murad to subdue them. In the section on Galilee in Palestine, Tahțāwī again omits substantial chunks of Malte-Brun, about the ancient monuments and Christian associations of Galilee and Nazareth (as well as an aside on the 'malignant genius' of the 'famous tyrant' Jazzar Pasha), and instead inserts references to more recent matters: the contemporary state of the population and monastery of Nazareth, and the account of a battle between the French (Napoleon's Armée de l'Orient) and the Ottomans in 1214 AH. Into Michelot and Meissas’s notice on Missolonghi, Ṭahțāwī is careful to insert the role of Egyptian forces in besieging the town during the Greek war. ${ }^{411}$

As with the insertion of Jomard's information on military strength and revenue, we can see here the priorities of utilitarian realpolitik - who is paying tax to whom, recent military history - replacing the Christian and antiquarian preoccupations of Malte-Brun. There is a particularly skilful example of Ṭahțāwì's adaptation of the French text to reflect lustre on his Khedivial master, in this section on Syria. Malte-Brun had concluded his general remarks on Syria thus:

In fine, the pashâs of Tripoli and of Seyde or Acre, have provinces almost entirely consisting of Maronites, Druses, and other independent tribes. The anarchy consequent on this political situation assumes different aspects, according to the character and conduct of the pashâs themselves, the emirs of the Druses, and the Arabian sheikhs. Enterprising chiefs erect independent states for a moment: yet Syria always returns under the unsteady yoke of the Turks. The unhappy condition of the people continues unchanged. The agriculturalist is continually pillaged by the authorized robberies of the pashâ, and the predatory attacks of the Arabs. The traveller can only have his choice of different bands of robbers for his escort. Art and industry languish for want of vigour and of information. Commerce, exposed to arbitrary vexation, is confined to timid bargains, or consigned to all the risks of caravans. Such is the deplorable condition of a country, rich in its soil, important in its local position, and which might, by a new crusade, be easily wrested from the grasp of its barbarous oppressors. ${ }^{412}$

The passage undergoes a remarkable transformation in Tahțāwī's version. This is aided by

411 Maronites: al-Ta rī̄bāt al-Shāfiya, 1: 153-4; Universal Geography: Or A Description of All Parts of the World, on a New Plan... (Philadelphia: A. Finley, 1827), 1: 357-8; Galilee: al-Ta rībāt al-Shāfiya, 1: 152; Universal Geography, 1: 355, 359-60; Missolonghi: al-Ta 'rībāt al-Shāfiya, 1: 134; Nouvelle géographie méthodique, 180.

412 Universal Geography, 1: 352. 
the fact that Malte-Brun's text had been written before the takeover of these Syrian pashaliks

by Mehmed Ali:

The pashalik of Tripoli has now been abolished and its eyalet divided between the eyalets of Damascus and Acre. These eyalets have now entered the possession of the Dispenser of Bounties, the governor of Egypt. God willing it will now have left the injustice of the pashas and the Arabs - for the peasants, though they were safe from the ruler, were not safe from the depredations of robbers. God most high willing, by the care of the Dispenser of Bounties arts, industries and sciences will enter them [these provinces] - for arts and industries are feeble in them due to the lack of justice and aid to property-owners, because trade in them [these provinces] is exposed to losses caused by injustice, aggression and the plunder of caravans, despite the fact that this land is rich with the aid of its soil, important in its position, which necessitates a condition of trade greater than that which it now has. One of the Frank authors has said that if it altered from this condition, its matter would be resolved; and if not, it would be easy for it to be conquered by a Frankish invasion, and it would fall into the hands of the Franks. Finis. ${ }^{413}$

The evils in government which Malte-Brun mentions are retained, but imputed to the "pashas and the Arabs' of the time before Mehmed Ali's occupation. The other evils are admitted, but it is assumed that Mehmed Ali's rule is relieving them. Malte-Brun's intuition that Syria, by its natural advantages, might achieve a state far beyond its current one, is presumed now to be on the way to being fulfilled under the Egyptian pasha's rule. The associated notion of Malte-Brun's, that Syria was most likely to achieve this happy state under European rule, after a 'new crusade', is again retained by Țahțāwī, but in a wholly different context: this is now a danger, against which Mehmed Ali's occupation is presented as the only effective bulwark. Even while depending on the 'Frank authors' as a source, Tahțāwī shows himself in the name, we may presume, of his Khedivial master - acutely aware of the danger of European imperial encroachment on the 'Egyptian countries'. We can find similar adaptations of the French source texts in the interests of Mehmed Ali's dynasty elsewhere in

413 Al-Ta 'rībāt al-Shäfiya, 1: 151.

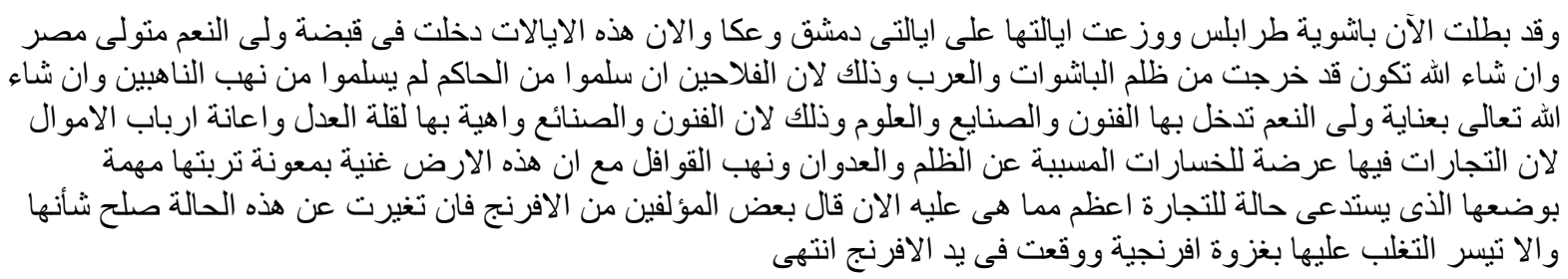


the sections on the 'Egyptian countries': Țahțāwī's rewriting of Malte-Brun's passage on the French occupation of Egypt and Mehmed Ali's rule; his careful treatment of Meissas and Michelot's criticism of Mehmed Ali's policies of economic monopoly; his adaptation of Malte-Brun's general remarks on Arabia, suggesting the strength of these lands if ever politically united, as they were close to being under Mehmed Ali. ${ }^{414}$

\section{Islam and the Ottomans}

But it was not only Mehmed Ali's dynasty itself that required alterations in the French texts; there were also the Ottoman Empire and the Islamic religion. Both in al-Jughräfiya al'umūmìya and al-Ta 'rībāt al-shäfiya, Țahțāwī modifies remarks by the French writers which do not show a sufficient respect for Islam. Where Meissas and Michelot list the world's religions, they place Christianity first:

Tous les peuples reconnaissent l'existence de quelque divinité, mais tous n'honorent pas de la même manière celle qui est l'objet de leur culte. Les principales religions répandues sur la terre sont : le christianisme, le mahométisme, le brahminisme, le boudhisme, qui reconnaissent un seul Dieu; et le polythéisme, comprenant toutes les religions qui enseignent l'existence de plusieurs divinités.

Le CHRISTIANISME est la religion révélée par JÉSUS-CHRIST. Il étend sa bienfaisante influence sur les peuples les plus civilisés; il est pratiqué par le tiers des habitants de la terre.

Their section on Islam comes after Christianity and Judaism, and begins: 'Le mahometisme ou islamisme se divise en deux sectes principales: celle des sunnites $[\ldots]^{, 415}$

Ṭahțāwī alters this to place Islam first:

414 Ibid., 1: 222; Universal Geography, 2: 444; al-Ta rībāt al-Shāfiya, 1:221; Nouvelle géographie méthodique, 222; al-Ta 'rībāt al-Shāfiyaal-Ta 'rībāt al-Shāfiya, 1: 175; Universal Geography, 1: 397. 415 Nouvelle géographie méthodique, 325-6. 
All nations hold that some divinity exists, whatever it may be, but they are not in all correct in their worship; rather, some are correct and most are in error. The basic religions present on the face of the earth are Islam, Christianity, Judaism, Brahminism and Buddhism, and these religions all maintain the oneness of God. As for the other religions, they maintain the multiplicity [of gods]. Now, Islam is divided into two main creeds: the Sunnis $[\ldots . .]^{416}$

In addition, he adds a criterion of correctness in religion (mușīb/mukhti') not present in the French. He also removes the Christian propaganda of the French original ('bienfaisante influence'). Otherwise, though, he translates fairly faithfully the 'Islam' section. In alJughräfìya al- 'umūmīya, too, we can see this dual solicitude both to alter passages where Malte-Brun is rather contemptuous of Islam, and to keep as much of the French text as possible. In sections on the religion of the Ottoman Empire, Tahtậī essentially keeps all the parts about Islam that could be construed positively, and omits the rest. He thus does his best to give the impression that Europeans' views of Islam are rather more positive than MalteBrun's text seems to warrant, adding at the end of this passage a claim that Europeans have now a better opinion of Islam than they used to (a considerable alteration from what MalteBrun says). ${ }^{417}$

Besides this concern to 'leave out all the statements that are derogatory and defamatory of Islamic customs', in the words of his introduction to Qalä 'id al-mafäkhir, we can find other concerns mingling them with religious ones. In his section on the religions of Syria, MalteBrun had unaccountably neglected to mention the presence of Islam at all, and simply begun with a description of 'the different Christian sects tolerated in this country'. Tahțāwī, translating the passage in his description of the provinces of 'Barr al-Shām', not only 416 Al-Ta rī̄oāt al-Shäfiya, 2: 47.

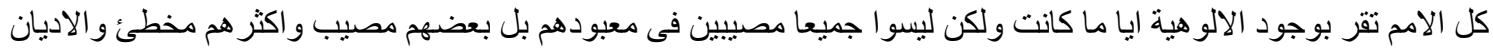

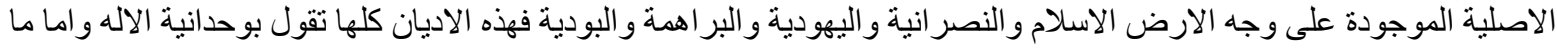
عدا هذه الاديان فانه قائل بالتعدد فالاسلام بنقسم الى طريقتين اصليتين و هما السنية الالية

417 Universal Geography, 1: 272; al-Ta 'rībāt al-Shāfiya, 3: 88; See also his treatment of the 'Appearance of Mahomet' in the section on Arabia: Ibid., 3: 95; Universal Geography, 1: 277. 
mentions Islam first, but also insists on its ruling role:

And the Islamic religion is the predominant one which holds sway over them [these provinces]; other religions are present, like the religion of the Syrian Christians $[\ldots . .]^{418}$

Here we can detect not only a pious inclination in favour of Islam, but also, it seems to me, a preoccupation with power-politics: it is as the ruling and politically established religion that Islam is important in this region. In a reference which follows to the 'Mutawallis' (i.e. Alawites) of Syria, Țahțāwī makes it clear that they are considered heretical, describing them as rawäfid, 'refusers' or 'renegades': a standard though pejorative Sunni epithet for the Alawis as well as other Shias, but later embraced by the Shia themselves. ${ }^{419}$

It is interesting, in this connection, that he does not pay much attention, in the section on Arabia, which he enlarges with materials from Malte-Brun and elsewhere, to the Wahhabis, and this despite the existence of a lengthy passage dealing with them in Malte-Brun's Précis. It is of interest, however, that when he came to translate the latter work in full, as alJughräfìya al- 'umūmìya, he reproduced this passage, he added some saj 'remarks on the Wahhabi doctrines, and also two notes, in brackets, stating that the talk of the power of the Wahhabis refers to the time when Malte-Brun's book was written, and that Mehmed Ali has since crushed them. ${ }^{420}$

Ṭahțāwī also shows a certain solicitude towards the Ottoman Empire. This is apparent, firstly, in his treatment of those regions which had recently been detached from it. As mentioned above, he lists the Greek provinces and towns among the Ottomans' possessions rather than as a separate country, and omits Meissas and Michelot's reference to their 418 Al-Ta 'rībāt al-Shāfiya, 1: 150; Universal Geography, 1: 352.

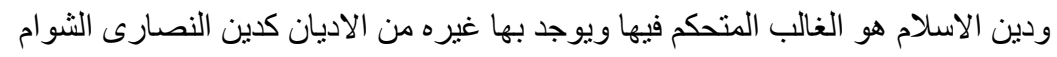

419 Ibid; ibid.

420 Universal Geography, 1: 389-90; al-Jughrāfìya al- 'umūmìya, trans. Rifā'a al-Ṭahțāwī (Būlāq: sn, 1838), 3: $101-2$. 
independent state under a Bavarian princeling. ${ }^{421}$ He translates the original passage from Michelot and Meissas on their war of independence (here, the French 'ont [...] secoué le joug de leurs oppresseurs' becomes 'kharajū [...] 'an țā' at malik al- 'Uthmāniyya wa-ṭalabū al-hurriya'). ${ }^{422}$ But he also adds a couple of notes - perhaps his own, or from other sources on the rebellion of the Greeks, in which it is clear that they are considered rebel subjects of the Sultan (for instance: 'wa-min hādhihi al-jazā' ir mā kharaja 'an al-țā'a ba 'd al-fitna [...]'). In one of these he admits, perhaps a little reluctantly, that 'the reader must remove [these lands] from the map of Ottoman countries'. He also inserts references, not in Meissas and Michelot, to the role of the 'allied European states' in bringing about the Greek secession. ${ }^{423}$

From the section on North Africa he also omits one crucial sentence from Meissas and Michelot's account: 'Alger appartient à la France.' In description of the town of Algiers, the French geographers had written only: 'ALGER (20,000 hab.). Cette ville a été conquise par les Français en 1830.' Tahțāwī adds a brief history of the reasons behind the conquest by the French, and concludes that Algiers is 'now in their hands' (wa-hiya al-än fì aydīhim). As in the case of independent Greece, the wording suggests that this new state of affairs is not entirely legitimate. ${ }^{424}$

It is also clear that Țahțāwī considers Mehmed Ali’s government, including his recently conquered lands, as part of the Ottoman state. Meissas and Michelot had listed the Ottoman 'possessions outside Europe' as Asiatic Turkey, the western part of Arabia, and Egypt. Ṭahțāwī adds to these Nubia and the Sudan (lands more recently claimed by Mehmed Ali),

421 Al-Ta rībāt al-Shāfiya, 1: 126-9 (provinces), 1: 129-134 (towns); Nouvelle géographie méthodique, 17980.

422 Nouvelle géographie méthodique, 175; al-Ta 'rībāt al-Shāfiya, 1: 125.

423 Al-Ta 'rībāt al-Shäfiya, 1: 128, 136; cf. Jomard's suppression of mention of the Greek war from the almanac he compiled for the Egyptian students' mission in Paris: Alain Silvera, 'The First Egyptian Student Mission to France under Muhammad Ali', Middle Eastern Studies 16, no. 2 (1980): 12.

424 Al-Ta 'rībāt al-Shāfiya, 1: 206-7, 208; Nouvelle géographie méthodique, 217, 219. 
and also the lands of 'the West' (al-gharb), i.e. North Africa, except the Kingdom of Marrakesh. He explains that Algeria, Tunis and Tripoli are Ottoman Qaim-maqamiyas, i.e. ruled by representatives of the Ottoman Sultan. ${ }^{425}$ At no point does his text suggest that Mehmed Ali is seeking to be independent of the Ottoman state, or put him in the same category as the rebellious Greeks, who 'kharaj[ $\overline{\mathrm{u}}]$ 'an al-țā'a ba 'd al-fitna'.

In a similar fashion, Țahțāwī in al-Ta 'rībāt al-shāfiya and al-Jughrāfìya al- 'umūmīya translates statements of Malte-Brun's on the 'despotic' nature of the Ottoman Empire, alters them, and adds, in al-Ta 'rībāt al-shāfiya, another 'note' from a different source, presenting a different view. ${ }^{426}$ Similarly, his pupil Khalīfa b. Maḥmūd adds to his translation of William Robertson's A View of the Progress of Society in Europe an appendix in which he takes issue with Robertson's description of the Ottoman Empire as despotic. In doing so he draws not only on his own knowledge, probably from Arabic or Ottoman sources, of Ottoman history the depositions of sultans, the power of the diwan and of the Islamic religion - but also on European writers who had themselves defended the Sublime Sultanate from the imputation of despotism, chiefly the Sicilian Alfio Grassi. ${ }^{427}$ This direct contestation of a European author, though drawing on other European authorities (as Khalifa claims, to avoid the imputation of pro-Islamic and anti-Christian bigotry) is unusual in the writings of the period, but not entirely absent. A similar example of criticism of a European text about the East is found, for instance, in Khalīl al-Khūrī's 1859 novella Way, idhan lastu bi-Ifranjī (Alas! then I am not a Frank), where he cites, translates into Arabic, and then pokes good-natured fun at a florid orientalist poem of Lamartine's. On the line, addressed to 'une jeune Arabe', 'Tu t’asieds sur la natte, à Palmyre émaillée', he comments:

425 Nouvelle géographie méthodique, 179; al-Ta 'rībāt al-Shāfiya, 1: 136.

426 Al-Ta rì̄bāt al-Shāfiya, 1: 143, 1: 126.

427 'Barāhīn jaliyya fī naqụ mā qīla fĩ al-dawla al- 'uthmāniyya', Kitāb itḥâf al-mulūk al-alibbā' bi-taqaddum al-jam 'iyyāt fì bilād Ūrūbbā: wa-huwa al-muqaddimah li-tārīkh al-Imbirātūur Sharlakān (Cairo: Maṭba'at Būlāq, 1258), 1: 364-389. 
We think all those of Eastern taste will not be able to restrain themselves from [feeling] distaste, when these noble senses strike their ears, especially the question of the mat (hașirra: French natte) which every Eastern reader will laugh at [....]

For our part, we do not think that a woman like the one he mentions was sitting on a mat, a thing which [even] the low people of our country dislike doing [...] If we considered it to be, as he says, one of the ruins of Palmyra - well, we have never heard of anyone from Beirut fetching a mat from Palmyra $[\ldots . .]^{428}$

I hope to develop a more detailed analysis of these examples of contestation of European authority elsewhere. For now we need only note that they existed. By means less obtrusive than these - additions and alterations - Țahțāwī, in al-Ta 'rībāt al-shāfiya, produced something rather different from Meissas and Michelot's textbook. The appearance of a standardised, universal, methodical order is maintained, in the retention of their general layout and numbering. It is less glaringly Eurocentric than that of Meissas and Michelot, though the Eurocentric and Francocentric bias of the latter is still present. ${ }^{429}$

But the 'equivalence and balance, proportion and parallel' which Ṭahțāwī sought to introduce in al-Ta 'rībāt al-shäfiya is only attempted for the Egyptian and to a lesser extent the Ottoman lands, and not for other parts of the world (an exception is the insertion of a

428 Way, Idhan Lastu bi-Ifranjī, 2nd ed. (Beirut: al-Maṭba 'a al-Sūriyya, 1860), 27.

$$
\begin{aligned}
& \text { نظن ان كل ذى ذوق شرقى لا يتمالك نفسه عن النفور حينما تقرع باب اذانه مطرقة هذه المعاني الثريفة ولاسيما مسئلة الحصيرة }
\end{aligned}
$$

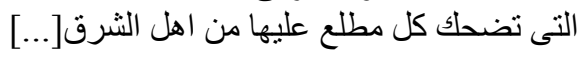

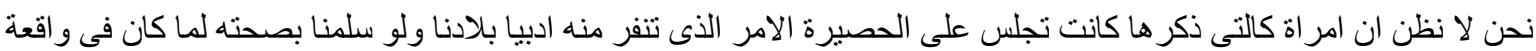

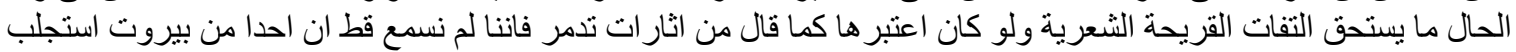

$$
\begin{aligned}
& \text { حصيرة من تدمر[.... }
\end{aligned}
$$

429 Thus comparing it to the Eurocentric and Francocentric textbook of Meissas and Michelot, we find only 117 of 293 pages devoted to Europe, and 176 to the rest of the world. The Eurocentric bias, in terms of space, is therefore less glaring, though still present. Of the 117 on Europe, around half (56) are on France: thus the Francocentric bias, within Europe, is maintained. (This is despite Țahțāwī's having apparently dropped the detailed descriptions of individual French départements - al-Ta 'rībāt al-shāfiya 1: 69, but is explained by his having also omitted parts considered insignificant in the sections on other European countries - or parts considered ideologically unwelcome, as with Greece. But of the 176 pages devoted to the world outside Europe, significant additions have only been made to the sections on the Asian provinces of the Ottoman Empire (especially Bilād al-Shām), Arabia, and of course Egypt. These accordingly take up 69 of the 176 pages; of these 69, 30 are devoted to Egypt. (These additions are made only to the section on political geography, not the shorter one on physical geography which precedes it; we could take them only in relation to the 167 pages on non-European political geography.) 
three-page note about the black people of Africa). ${ }^{430}$ Where Tahṭāwī has intervened, he has done so in the interests of the Khedive's rule, considered as part of the Ottoman Empire, as well as to preserve the religious decencies. This produces an Egyptian-Ottoman imperial geography, superimposed on a Euro- and Francocentric one; moreover, a practical, even 'utilitarian' work, produced in response to the decision to teach geography in the military and bureaucratic schools. And almost all of Țahțāwì's material is still taken from European sources, though these are various: Malte-Brun's more detailed and more 'humanistic' Précis, which he later set about translating in full, added to Meissas and Michelot's brief though 'methodical' textbook. It seems to take nothing in terms of either content or organisation, from the older Arabic geographical literature described above. But the European materials are, where it matters, rearranged and combined according to Ṭahțāwī’s (and the Khedive's) priorities. If knowledge was power, it could be so for Mehmed Ali's dynasty and its servants, as well as for Europeans. And if the forms into which knowledge was cast bore the marks of a particular centre of power - well, they could be recast, to a point, in the service of another one.

Geography continued to be a topic of interest to the Arab Nahda, besides Tahțāwī's intense engagement with it. Two travel works are among the translations made by the Damietta Circle early in the century; the Bulaq press continued to print geographical and travel works: we can note, from the 1830s and 1840s, a Géographie physique by Lamouroux, two manuals on map-making and surveying, and two European travel narratives of America and India. In the 1860s Yūsuf al-Shalfūn gave a lecture on the Geography of Syria Province to the Syrian Scientific Society in Beirut. In 1291/1875, the first volume of a planned encyclopedic work of geography and history by Salīm Jubrā' ̄̂l al- Khūrī and Salīm Mīkhā' īl Shahāahah appeared from Khalīl al-Khūrī's Syrian Press in Beirut (only two volumes seem to have been

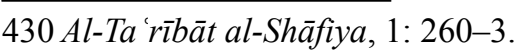


published). The geographical sections of the Bustānīs' Dā'irat al-ma 'ārif(Encyclopedia), another never-to-be-completed encyclopedic enterprise, were extensive and detailed. Later in this chapter we shall see some traces of the Arabic press's interest in various parts of the world. $^{431}$

\section{Civilisation and Savagery}

European geographical literature of the kind Ṭahtāwī was reading and translating was suffused, as mentioned above, with notions of the gradations of human society, from savagery to civilisation or enlightenment. Depping's Aperçu is largely organised by this theme, with the manners and customs of different peoples described from the most primitive to the most refined or advanced. The point is clearly picked up by Ṭațāwī in his introduction, which begins, conventionally, with a saj 'exordium:

In the Name of God, the Compassionate, the Merciful:

Praise be to God, who knows truths, and rules all creatures; worshipped in the west and east, unique in divinity from those other than Him; praise be to Him, the God who created the worlds and enumerated them; and brought them near to progress (al-taraqqi) and far from it; and granted them recognition of divinity $[\ldots . .]^{432}$

Depping's criterion is then inserted into a conventional Islamic frame of reference: the

431 Shayyāl, Tārīkh al-Tarjama; Ayalon, 'The Arab Discovery of America in the Nineteenth Century', 9-10 and 13-14; Shalfūn's lecture is reproduced in Khūrī, A 'māl Al-Jam 'iyya Al- 'ilmiyya Al-Sūriyya, $153-66$. 432 Qalä id al-mafākhir, 2: 2. My underlining.

$$
\text { (*) باسم الله الرحمن الرحيم (*) (2) }
$$

$$
\begin{aligned}
& \text { الحمد لله العالم بالحقائق * المدبر سائر الخلائق * المعبود فى المغارب و المشارق المنفرد بالالو هية عما سو اه * فسبحانه من آله } \\
& \text { * خلق العو الم واحصاها * وقربها الى الترقى و اقصاها* و على الاعتر اف بالالو هية اوصاها }
\end{aligned}
$$


degrees of civilisation, derived from Europe, are placed alongside the Islamic criterion for judging or 'placing' different peoples: that of correctness in religion. A couple of lines later, the introduction exclaims:

'O woe unto whoever turns men away from holding to the law ( $\left.\operatorname{sharī}^{\prime} a\right)$ of Islam $[\ldots . .]^{\prime 433}$

A similar blending of the secular 'degrees' or 'stages' of civilisation with religious criteria is found in his section on 'religious geography' in al-Ta 'rībāt al-shäfiya. This is the only place in which he departs in any major way from Meissas and Michelot's 'Troisième partie', which deals with 'Cosmographie', 'Géographie physique', and the construction of maps. Meissas and Michelot had dealt, illogically enough, with 'Race humaine', including 'Religions' and 'Civilisation, gouvernement', under the heading of 'Géographie physique'. ${ }^{434}$ Ṭahțāwī instead creates a separate section: 'Fourth Part: Religious Geography' (al-Qism al-rābi 'aljughräfiyā al-dīniyya). Neither Meissas and Michelot nor Malte-Brun had included a section on 'religious geography'. Tahțāwî̀'s first topic under this heading is the passage we have already examined, derived from Meissas and Michelot's subsection on 'religions'. He then proceeds to place under 'religious geography' subsections such as 'Political Geography', 'Languages and Tongues', ‘Types of Laws and States', and 'Universal Geography'. Apparently 'secular' material is thus placed within the framework of 'Religious Geography'. Within these sections, he draws on other material besides Meissas and Michelot, including Malte-Brun. ${ }^{435}$

It is under 'Political Geography' that Ṭahțāwī outlines the 'stage theory' of civilisation

433 Qalā'id al-mafākhir fi gharīb 'awā'id al-awā'il wa-l-awākhir (The Necklaces of Glories, on the Marvellous Customs of the Ancients and Moderns), 2: 2. My underlining.

$$
\text { * فيا ويح من حاد فى الانام * عن التمسك بشريعة الاسلام }
$$

434 Nouvelle géographie méthodique, 325-7.

$435 \mathrm{Al}$-Ta 'rībāt al-Shāfiya, 2: 47-54; Sections which appear to derive from Malte-Brun are 'Languages and Tongues' and 'Types of Laws and States', as well as the account of the geographical location of different types of Christianity, and the figure of 5,000 for the adherents of Judaism: see Universal Geography, 1: $265 \mathrm{ff}$. 
explicitly. He first offers a definition of civilisational sociability and a history of man's

progress from his natural state:

\section{Political geography (al-jughrāfiyā al-siyāsiyya)}

Languages and religions are the bonds of moral (adabi) $)$, i.e. mental ( $m a$ 'naw $\vec{\imath})$, sociability ( $\left.i^{\prime} t i n \bar{a} s\right)$; as for civilisational (tamaddun $\left.\vec{\imath}\right)$ and political (siyās $\left.\bar{\imath}\right)$ sociability, its bonds are in laws ( $\left.\operatorname{shara}^{\prime} i\right)$ and statutes $(a h k \bar{a} m)$. For instance, if a people were to unite under the rule of one law, they would be a state. And it is well known (' ' $\bar{u} m$, sic - read: $m a$ ' $\bar{u} m$ ) that man was originally innocent (sādhijiyya) and free of ornament, existing in his original nature, without knowledge. Then knowledge came upon him, and his acceptance of perfection in giving and getting, and the more he grew distant from his original condition and became skilful in intercourse (ikhtilatt) and association (mu' 'ashara), strong in the means of sociability (ta'annus) and subsistence (ta 'ayyush), and advanced (taraqqa) in industries and the varieties of prosperity ('umrān) and civilisation (tamaddun), the more he grew cultured ( $\left.a^{\prime} d a b\right)$, and refined, and great in his civilisation (tamaddun). ${ }^{436}$

The first phrase, like the heading 'Political Geography', apparently derives from Malte-

Brun: 'Languages and religious creeds are the ties of moral society, which often survive the

fall of civil and political society; but it is the latter which determines the boundaries of states and empires $[\ldots .]^{\prime 437}$ The succeeding pages of the Précis outline the history of humanity's progress in various aspects (regarding government, the division of labour and classes, and armed forces) - Țahțāwī has perhaps condensed all this into his own version, or used another source.

He then proceeds to give the classic tripartite division of peoples:

For this reason, some have divided people according to the manner of their subsistence (ta 'ayyush) and politeness ( $\left.t a^{\prime} a d d u b\right)$, or its absence, into three grades (marātib): the first grade is that of the savage nomads (al-hummal al-

436 Al-Ta 'rībāt al-Shāfiya, 2: 48-9.

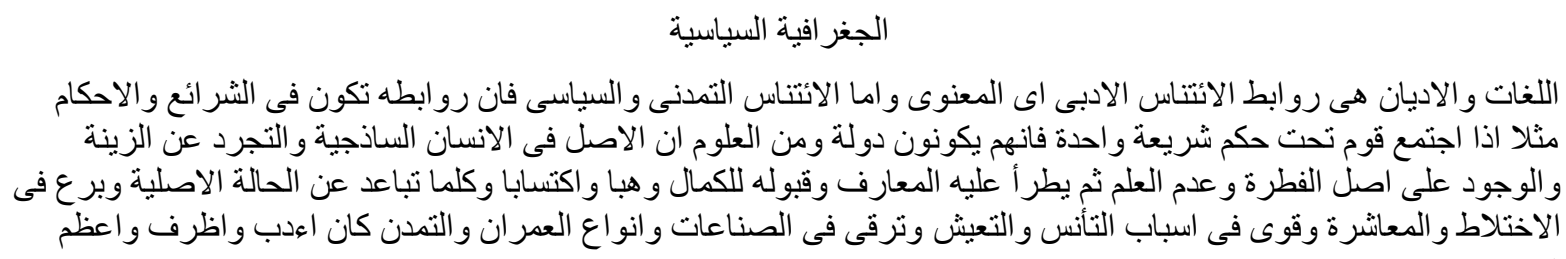

437 Universal Geography, 1: 273. 'Al-adabī ay al-ma 'nawī' is evidently Tahtawi's attempt to convey the dual meaning of the French 'moral'. 
mutawahhishin); the second is that of the barbaric, coarse people (ahl al-khushüna al-mutabarbarin); the third is that of the civilised (mutamaddinin) people of culture $(a d a b)$, elegance (zaräfa) and knowledge (ma'rifa). ${ }^{438}$

And offers examples of each stage:

An example of the first grade are the nomads of the countries of the Sudan and America, who are still like roaming beasts, who do not know right ( $h a l \bar{a} l$ ) from wrong (harām), cannot read or write, adopt no industry, and know nothing at all of the varieties of prosperity ( 'umrān), but are driven by their passions as their desires decree, like beasts. They cultivate [the land] sometimes, or hunt, merely to keep themselves alive. An example of the second grade are the Arabs of the desert: they are sociable and subsist together (yata'annasūn wa-yata 'ayyashün); they know right from wrong; they know how to write and read, and hold to a law ( $\operatorname{shari~}^{`} a$ ). But of the sociability (ta' annus) which belongs to the people of large cities they possess nothing whatsoever: thus the means of good livelihoods, industries and prosperity ( 'umrān) are not brought to perfection among them. And how could this be so, when they do not know how to build a house, and seek shelter from heat and cold by lesser means? But they excel at breeding animals and cultivating the earth. An example of the third grade are the countries of Egypt, al-Shām, the Turks, the Persians, the Arabs, some of the countries of the West (al-Maghrib) and China, the countries of America, and so on. These [countries] on the whole possess prosperity ( 'umrān), polities (siyāsāt), sciences, laws ( $\operatorname{shar} \bar{a} i)$ and industries ( $\left.\operatorname{san} \bar{a}^{\prime} i\right)$; tools, instruments, and devices in the varieties of livelihood have been brought to perfection among them. This grade differs in its varieties and the goodness of their condition, their adoption of the law (taqlìdiha al-shar $\bar{l}^{\prime} a$ ), and their advancement (taraqqū $)$ in industries and the sorts of refinement. So it is called the grade of civilisation (martabat al-tamaddun), and in its beginning it is called the grade of half-civilisation, and the grade of half-civilisation can [also] be applied to what came before it, i.e. the second grade. ${ }^{439}$

This passage seems to derive partly from Meissas and Michelot's section on 'Civilisation, gouvernement', which runs:

Les peuples, d'après leur manière de vivre et les progrès qu'ils ont faits dans les arts, peuvent se diviser en trois classes.

$1^{\circ}$ Les sauvages n'ont pas d'autre culte que de vaines superstitions; ils ne

438 Al-Ta'rībāt al-Shāfiya, 2: 49.

$$
\begin{aligned}
& \text { فلهذا قسم بعضهم الناس باعتبار كيفية تعيشهح وتأدبهم و عدم ذلك الى ثلاثة مر اتب المرتبة الاولى مرتبة الهمل المتوحشين * الثانية }
\end{aligned}
$$

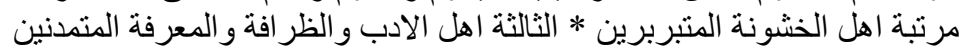

439 Al-Ta 'rībāt al-Shāfiya, 2: 49.

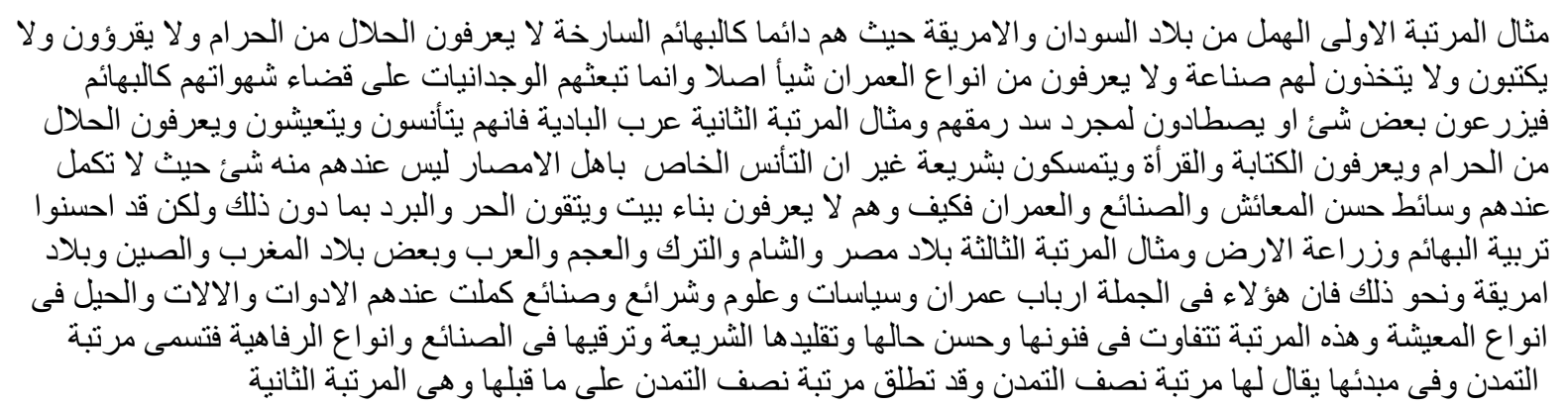


connaissent point l'art d'écrire; leur industrie se borne à un peu de jardinage, à la pêche, à la chasse; ils sont ordinairement nomades ou errants, et ne forment que de très-petites peuplades.

$2^{\circ}$ Les peuples barbares ou demi-civilisés ont un culte religieux et des lois; ils connaissent plusieurs arts, même celui de l'écriture. Les uns s'adonnent à la culture des terres, d'autres à l'éducation des troupeaux: ces derniers sont nomades.

$3^{\circ}$ Les peuples civilisés ont perfectionné les arts mécaniques; ils cultivent les sciences, les lettres et les beaux arts; ils ont, par leurs lumières, par la sagesse de leurs lois, et par leur commerce, augmenté la population, l'aisance et le bonheur général. ${ }^{440}$

But this section from the Nouvelle géographie méthodique seems indebted in its turn to Malte-Brun's account of the 'Classes of nations' (the phrase 'leur industrie se borne [ordinairement] à un peu de jardinage, à la pêche, [et] à la chasse', for instance, is found in the Précis with the addition of the two words indicated), and Ṭahțāwī may well have drawn directly on the latter source once again. ${ }^{441}$ Such an outline was in any case a common feature of geography textbooks of the period; the exact source or sources matter far less than Ṭahțāwì's use of them. Three aspects of this stand out. Firstly, to convey ideas such as 'civilisation' and 'society', he has drawn on an existing Arabic tradition of thinking about such matters, which goes back to Ibn Khaldūn and beyond. Such terms as 'umrān and $i^{\prime} t i n a \bar{s}$, as well as tamaddun itself, relate to this. Secondly and relatedly, he has introduced local examples of all the 'classes' of 'grades': the people of the Sudan, the desert Arabs, and the people of Egypt, al-Shām, and so on. The distinction between the settled people and the nomadic Bedouin had of course been one of Ibn Khaldūn's key concepts, and Ṭahțāwī’s distinction between the 'people of large cities' and nomads may well relate to this. He has also introduced non-local examples: the native Americans, China, and 'the countries of America', though not, interestingly, the Europeans. He ends on a note of ambiguity: the 'beginning' of the third, civilised, grade may be termed 'half-civilisation', but this can also

440 Nouvelle géographie méthodique, 327.

441 Universal Geography, 1: 281-2; Précis de la géographie universelle, ou Description de toutes les parties du monde, sur un plan nouveau... (Paris: Fr. Buisson, 1812), 2: 610. No traces remain in the Arabic, however, of the positive qualities which Malte-Brun concedes to the 'savages': their superiority to the civilised in 'bodily exercise', and their sometimes 'beautiful workmanship' and 'commodious and elegant habitations'. 
apply to the second (barbaric) grade.

Thirdly, Țahțāwī has placed 'Egypt, al-Shām, the Turks, the Persians, the Arabs, some of the countries of the West (al-Maghrib) and China' firmly within the third, civilised grade. This is not something that most writers of European geography textbooks would have done. Meissas and Michelot do not give examples in their scheme of classes; nor does Malte-Brun, although he does mention Christianity in his definition of 'civilised nations', and elsewhere expresses the hope that 'Asiatic Turkey [...] will, at some future time, be again subjected to the benign influence of civilisation' - which does not suggest a very sanguine view of the present civilised status of the Ottomans. ${ }^{442}$ American textbook writers were more explicit: Joseph Emerson Worcester, in 1819, placed 'Arabia' in 'the barbarous state', and 'Turkey, Persia, Hindoostan, and China' in a 'half-civilised state'. Channing Woodbridge, in 1824, similarly placed 'China, Japan, Southern Asia, Persia, Turkey, and Northern Africa' in the 'half-civilised state'; he also put 'Poland, Portugal, and a large part of Russia' in a merely 'civilised' category, reserving the term 'enlightened' for 'most of the nations of Europe'. Albert M. Craig gives a most interesting account of the translation and use of such material, from a comparable perspective to Ṭahțāwì's, by the Japanese intellectual Fukuzawa Yukichi. In 1869, translating an American geography, Yukichi left China in the original list of 'halfcivilised' countries - along with Turkey and Persia - but removed Japan. In 1875, in his Outline of Theories of Civilisation, he placed Japan too in the 'half-civilised' category, and insisted that his country must now aspire to attain the full 'civilisation' which existed only in Europe and America. As Craig rightly says, this second approach was far more 'iconoclastic' than Țahțāwī's: it pointed up the differences between Japan and 'the West' far more sharply, and led to a clearer call for radical change. ${ }^{443}$

442 Universal Geography, 1: 282, 367.

443 Civilization and Enlightenment, 34-8 (Worcester and Woodbridge), 48-50, 103-5, 159-60. See also 11-32 for some of the earliest version of this 'stage theory' of civilisation in the Scottish Enlightenment. 
Ṭahtậi is aided in eliding the differences between Europe and the Arab or Islamic world by his calquing of the civilised/barbarous distinction onto the Khaldūnian settled/Bedouin distinction: the division between town people and nomads comes to overshadow that between Europe and countries such as Egypt or Persia. He has also admitted that there are inequalities between the peoples within the third category, and left a certain ambiguity to 'half-civilised', as potentially referring to the 'beginning' of the 'civilised' stage or class as well as to the 'barbaric' second class. Egypt and other Islamic lands might thus be called 'half-civilised', but this could be taken to mean that they were 'on the whole' (fi al-jumla) within the 'civilised' third class. ${ }^{444}$

The question of divisions within this third 'civilised' class of nations and peoples is dealt with directly in the first chapter of Țahțāwî̀s introduction to Takhlīṣ al-ibrīz, in a passage that appears to be an expanded version of the one quoted above from al-Ta 'rībāt al-shäfiya. Here Țahțāwī has expanded his initial potted history of mankind to include several examples of technological inventions (e.g. fire, shipbuilding) leading to progress. He again divides people into three degrees or grades (darajāt or marātib), and places 'the nomads of the country of the Sudan' in the first, and the Arabs of the desert in the second. As for the third:

The third grade includes Egypt, al-Shām, Yemen, the lands of the Rum, Persia, the Franks, the Maghrib, Sennar, most of the lands of America, and many of the islands of the Encircling Sea [Oceania]. All of these nations (umam) possess prosperity ('umrān) and polities (siyās $\bar{a} t$ ), sciences ('ulüm) and industries (sinā' 'ât), laws $\left(\operatorname{shar} \bar{a}^{\prime} i\right)$ and trade (tijārât). They have perfect knowledge of the instruments of industries, and the devices used to carry heavy loads by the easiest of means, and are familiar with seafaring and things like it.

[The countries of] this third grade differ in the sciences and arts, the goodness of their condition, their adoption of a particular law (taqlìd sharì $a$ min al-sharì $^{-} a$ ), and their progress (taqaddum) in craftsmanship. For instance, the Frankish lands have attained the highest degree of proficiency in mathematics, natural sciences and metaphysics

444 There are perhaps similarities in Yukichi's 1869 translation of 'half-civilized' as ' mikai or 'not yet enlightened',' and his insistence on the relative nature of 'civilisation' in his Outline: Ibid., 48-50, 107-8. 
[...]. Nevertheless, they have not pursued the straight path, or entered upon the road towards salvation.

The Islamic countries, for their part, have excelled in the legal sciences and their application, and in the rational sciences, but have neglected the philosophical sciences entirely. For this reason they need the Western countries to acquire what they do not know. ${ }^{445}$

The first part of this passage is evidently very close to the one from al-Ta 'rìbāt al-shâfiya quoted above, with some changes of wording and of the countries listed. The latter part, from 'For instance, the Frankish lands [...]', develops the point of the 'difference' or 'discrepancy' (tafāwut) between the 'civilised' peoples. The Franks have an advantage in the 'philosophical sciences' - here the examples of mathematics, natural sciences and metaphysics are given, but a few pages later Ṭahțāwī sets out the various practical sciences and crafts which Egypt has to learn from the West: such things as law, engineering, military arts, medicine, etc., closely corresponding to the translation and education project of Mehmed Ali's state at the time. ${ }^{446}$ The 'Islamic countries' have the advantage in the legal and 'rational' ('aqliyya) sciences, and this is presented, in this passage, as a corresponding civilisational good, which the Franks (who 'have not pursued the straight path') obviously lack. A religious criterion of civilisation is thus explicitly introduced. Something of the kind had been at least implicit in Ṭahțāwì's exordium to the introduction to Qalä 'id al-mafākhir, quoted above, or perhaps in his employment of words with a religious connotation, like alsharī'a or halāl/harām, in al-Ta 'rìbāt al-shäfiya. This notion of the corresponding, balancing

445 Takhlīṣ al-Ibrīz fì Talkhịs Bārīz, 1st ed. (Būlāq: al-Maṭba a al-Khudaywiyya, 1250), 5-7; translation Newman, An Imam in Paris, 101-105.

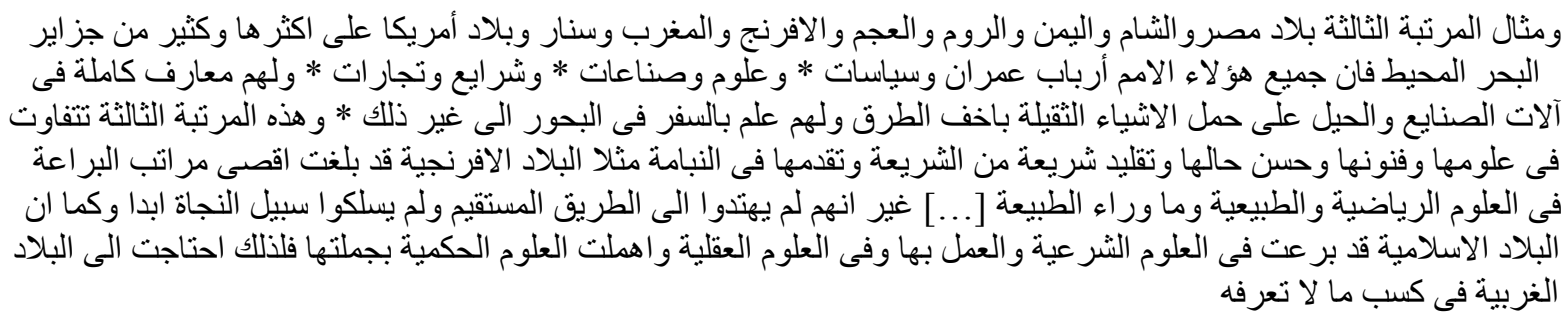

See also Newman's extensive notes on the terminology used in this section, and other examples of Tahtawi's use of such terminology elsewhere in Takhlīs al-ibrīz.

446 Takhlīṣ al-Ibrīz, 10-11; Newman, An Imam in Paris, 111-3. 
advantages of the Islamic countries and the West or the Franks is then used to justify seeking specific kinds of knowledge from them (the chapter of Takhlīs al-ibrīz from which the last extract was taken specifically sets out to justify 'our departure to this country, which is the abode of Infidelity and Obstinacy'). ${ }^{447}$

In this manner, Tahțāwi takes over the scheme of the stages or grades of civilisation from his European sources, placing the Egyptians and other Islamic peoples in the third, 'civilised' grade, separated from Europe only by (reciprocal) differences (tatafāwat). Both these and Europe, on the other hand, are placed in a different category entirely to the 'Arabs of the desert', and still more so the 'nomads of the Sudan' - both categories of people which, of course, Mehmed Ali's state was then attempting to subdue and conquer. Țahțāwī's tour d'horizon of the countries of the world, in another section of the introduction to Takhlīs alibriz, contains the pious wish that Islam may spread in Africa 'to the unbelievers of the Sudan (kuffār al-Sūdān), thanks to the efforts of the Dispenser of Bounties - may God the Almighty protect him' ${ }^{448}$ A religious justification for Mehmed Ali’s civilising mission - like the European geographers' Christian ones for the spread of the civilisation of Europe - was thus to hand. One of Ṭahțāwī’s few additions to the non-European and non-Egyptian or Ottoman world, in al-Ta 'rībāt al-shäfiya, was a three-page section entitled 'Reports and rarities about the countries of Africa concerning the black people that are in them', replete with evidence of the strange habits of the black Africans, the 'coarseness and crude nature' of their rulers, and so on. This concludes optimistically:

One cannot despair of the countries of the blacks (südān) prospering like other nations; but they need civilisation (tamaddun) to be introduced into them, and progress engendered among them, by intercourse with other [peoples]. ${ }^{449}$

447 Takhlīṣ al-Ibrīz, 5.

448 Ibid., 16; translation adapted from Newman, An Imam in Paris, 122.

449 Al-Ta 'rìbāt al-Shāfiya, 1: 260-3.

فلا يمكن للانسان الياس من ان بلاد السودان يفلحون كغير هم من الامم بل ينبغى الاخذ فى اسباب تمدنهم وتوليد الترقى عندهم

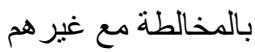


When we consider the place in the world, and on the scale of civilisation, barbarism and savagery, which intellectuals like Ṭahțāwī in Egypt were claiming for themselves, we must remember that they were facing, as it were, two ways. On the one hand there were the countries of Europe and the West, with their excellence in 'philosophical sciences' and in very practical arts and skills. With these they claimed parity, or potential parity. On the other hand there were these other peoples, who educated Arabs, like Europeans, were content to call 'savage' or 'barbarous': the blacks of the Sudan, the desert Arabs, the native Americans. As Eve M. Troutt Powell suggests, in her excellent study of Egyptian attitudes towards the Sudan, the claim of some non-European peoples to parity with Europe was bound up with their assertion of superiority over others - in this case with a specific imperial project to control the Sudan. ${ }^{450}$

\section{Ancient Geographies}

We can suggest one other reason why the affinity between Europe and the Near East countries such as Egypt and Syria - may have been easier to construct than one between Europe and, say, subsaharan Africa, or for that matter Yukichi’s Japan. It was, of course, modern, nineteenth-century Europe which Ṭahțāwī, and later others such as Bustānī or Marrāsh, had to come to terms with: the Europe of capitalism, industrialisation and empire.

There are other examples. Under 'religions', Meissas and Michelot had referred to polytheistic 'fétichisme' as being practised by 'peuples qui sont sauvages ou d'une profonde ignorance': Nouvelle géographie méthodique, 327; Ṭahțāwī adds 'the blacks of Africa' (sūdān bilād Ifrīqiyya) under this heading, as well as a reference to ancient peoples such as the Ancient Egyptians and 'jāhiliyyat al-Yūnān': al-Ta 'rībāt alShäfiya, 2: 48.

450 A Different Shade of Colonialism: Egypt, Great Britain, and the Mastery of the Sudan (Berkeley and Los Angeles: University of California Press, 2003), esp. 47-55 for Tahtawi's attitudes to the Sudan during his exile; Japanese intellectuals like Yukichi seem to have followed a similar path: thus he makes the point that 'civilised' is a relative term, in his Outline, by saying: 'the condition of China at present must be called half-civilized relative to the West. But if we compare China to the countries of southern Africa, or, more immediately, if we compare the people of Japan to the Ezo [Ainu], then both China and Japan are civilized.' Craig, Civilization and Enlightenment, 107. 
By the mid-nineteenth century, this Europe - or, we should more properly say, its dominant representative, the 'conquering bourgeois' - had constructed a vision of its own 'civilisation' as uniquely successful, outstripping not only all contemporary non-European countries but also all previous civilisations. Such a vision of the world comes through strongly - with a specific French twist, defining France as the pinnacle of this European civilisation - in Guizot's Histoire de la civilisation en Europe. This work was translated into Arabic by Hanīn Ni 'matallāh Khūrī and published in 1877, with a dedication, fittingly enough, to Khedive Ismail, who was to declare the following year:

Mon pays n'est plus en Afrique; nous faisons partie de 1'Europe actuellement. Il est done naturel pour nous d'abandonner les errements anciens pour adopter un système nouveau adapté a notre état social. ${ }^{451}$

It seems equally fitting that this remark was made in a speech addressed to Sir Rivers Wilson, accepting the results of the latter's Commission to enquire into Egypt's finances one more step along the road of financial entanglement which was to lead to Britain's invasion of Egypt in $1881 .{ }^{452}$ It was difficult to accept the Guizot version of European civilisation without also accepting the inevitability of European domination - hence the only way to attain to equality with Europe could seem to be, with Khedive Ismail, to become part of it. But in the eighteenth century, from which many of the works translated by Tahtận̄ and his pupils at the Language School dated, Europe had not yet attained quite this degree of triumphalism. The French philosophes could see in the Chinese Mandarins an enlightened class like themselves - as Victor Kiernan pointed out, this was not unrelated to the fact that France had no major Asian colonies until the later nineteenth century. ${ }^{453}$

451 Lord Cromer, Modern Egypt (London: Macmillan, 1908), 61-2; Kitāb al-Tuhfa al-Adabiyya fì Tārīkh tamaddun al-Mamālik al-Ürubāwiyya, trans. Ḥanīn Ni 'matallāh Khūrī (Alexandria: Maṭba'at al-Ahrām, 1877); reprinted ed. Yūsuf Qizmā Khūrī (Beirut: Dār al-Hamrā̄ , 1990); the translator gave part of the work as a lecture to Syrian Scientific Society in 1869: Khūrī, A 'māl al-Jam iyya al- ilmiyya al-Süriyya, 18681869.

452 Landes, Bankers and Pashas gives a brilliant account of these entanglements; for Ismail see also Lorne M. Kenny, 'The Khedive Isma'il's Dream of civilisation and Progress', The Muslim World 55, no. 2 (1965): $142-55$.

453 The Lords of Human Kind: Black Man, Yellow Man, and White Man in an Age of Empire (London: Cresset Library, 1988), 20-1. 
But there was also the fact that many European Enlightenment writers saw the process of 'enlightenment' or 'civilisation' in their own day not as a 'modern' phenomenon, but as a return to the civilisation of the Ancients - i.e. the Greeks and Romans - after a 'modern', meaning medieval, barbarism. ${ }^{454}$ They were not so much trying to do something new as to revive the old. Even long after the famous 'Querelle' of the Ancients and Moderns, many continued to hold that modern civilisation was inferior to ancient. By Ṭahțāwî̀s time, the Whiggish spirit of superiority was coming through, and he acknowledged it in Takhlīs alibrīz: the sages of England, France, and Austria, he writes, 'have surpassed the ancient scholars like Aristotle, Plato, Hippocrates and others like them [...]. Their philosophy is purer than that of their ancients [...]. ${ }^{, 55}$ But respect for Antiquity, the continual citing of ancient models and comparisons, continued.

The Ancients were relevant to 'modern', nineteenth-century inhabitants of lands such as Egypt and Syria because so many of them had in fact lived in these lands. And if these places had once been centres of civilisation, could they not be so again? The point was argued in the case of Syria, as we have seen, by Malte-Brun - and adapted by Tahțāwī. What I am suggesting is that the evidence, ever-present in the 'humanistic' works translated at Bulaq, of European respect for Antiquity, was potentially a powerful source of confidence for Arab intellectuals in their own countries' civilisational worth and potential. They were of course eager to pick up on any European acknowledgement of the role of the Arabs in the development of their own civilisation: Ṭahtāini claims in the Takhlīṣ al-ibrīz that the Franks 'acknowledge that we were their teachers in all sciences and that we had an advance on

454 This is argued cogently by J. G. A. Pocock, 'Perceptions of Modernity in Early Modern Historical Thinking', Intellectual History Review 17, no. 1 (2007): 79-92.

455 Rifā'a al-Ṭahțāwī, An Imam in Paris, 125. In 1852 an essay 'On the Superiority of the Moderns Over the Ancients' ('Fī fậl al-muta 'akhkharīn 'alā al-mutaqaddamīn'), by the missionary Cornelius Van Dyck, appeared in the Proceedings of the Syrian Society for the Acquisition of Arts and Sciences: $A$ ' $m a \bar{l} l$ alJam 'iyya al-Sūriyya, vol. 1, ed. Buṭrus al-Bustān̄̄ (Beirut: American Press, 1852), 71-75. 
them.' And of course 'credit goes to the precursor.' ${ }^{456}$ Bustān̄̄'s Ādāb al- 'Arab was one work which looked back to the earlier Arab Golden Age. Later, European works which acknowledged the flourishing of Arab or Muslim civilisation and its role in the development of Europe, like Gustave Le Bon's La civilisation des arabes (1884), or Carlyle's essay on Muhammad, 'The Hero as Prophet', were accepted willingly. ${ }^{457}$

But even in the absence of these, European respect for the Ancient or Classical world, and attention to its geographies, centred on the Near East and Mediterranean, could perhaps offset to some degree the European-dominated geographies of the modern world. Certainly the presence of Antiquity in the material translated from European languages into Arabic is remarkable. Ancient history had been one of the topics covered by the translations made at Damietta and Istanbul in the early years of the century, with part of Charles Rollin's Histoire ancienne and his Histoire romaine being translated - in addition to the two novels Télémaque and Bélisaire, set in ancient and Byzantine times. ${ }^{458}$ A history textbook translated by the missionaries at Malta, presumably from some English source, begins with, and devotes a large proportion of its content to, ancient history. ${ }^{459}$

Among the Bulaq translations two works dealt solely with the ancient world: the Mukhtașar tarjamat mashāhīr qudamā' al-falāsifa (Summary Biographies of the Famous Ancient Philosophers), 'Abdallāh Ḥusayn Effendi al-Mașrī's translation of Fénelon's Abrégé de la vie des plus illustres philosophes de l'antiquité (1252 [1836-7]), ${ }^{460}$ and the collective work 456 Ibid., 105.

457 Mitchell, Colonising Egypt, 122-5; Tageldin, Disarming Words, 152-94.

458 See my 'The First Arabic Translations of Enlightenment Literature: The Damietta Circle of the 1800s and 1810s', Appendix 1, A. 4 and A. 5., Appendix 2, 1 and 2.

459 Anon., Kitāb Tawārīkh Mukhtașar (Malta: Church Missionary Society Press, 1833); According to Roper this was a translation of William Pinnock, A Catechism of Universal History (1824): 'Arabic Printing in Malta 1825-1845', Appendix A, no. 48, 337-8.

460 This was corrected by Tahtawi - the translation has previously been misattributed to him. It is listed by Shayyal as Tärikh al-falāsifa al-yunāniyyīn: Tärīkh al-Tarjama, Appendix 1, no. 42. Neither he nor Newman $(289, n$. 1) identified the French original. The similarity in titles has evidently led to confusion with Levesque's work (see below). Reprinted at Istanbul 1302 (1884: Maṭba at al-Jawā'ib, as Tārīkh al- 
Bidāyat al-qudamā' wa-hidāyat al-ḥukamā' (The Beginning of the Ancients and Guide for the Wise: 1254 [1838]). This seems to have been, like al-Ta 'rībāt al-shäfiya, an exercise in contaminatio from several sources: in this case they were translated or compiled by various pupils of Tahtậ̄î̀'s and then combined by him into one book. As well as different European works, they include Classical Arabic sources: Ibn al-Athīr's al-Kāmil, Maqrīzī, Isfahānī’s Kitāb al-Aghān̄, and in the part about the ancient Arabs, many Arabic verses. ${ }^{461}$ Other works on the ancient world were among the books Ṭahtāwī studied in Paris: a work on 'the lives of the Greek philosophers' identified by Newman as Levesque's compilation Vie et apothegmes des philosophes grecs (1795); Montesquieu's Considérations sur les causes de la grandeur des Romains et de leur décadence, (1734; later translated by Hasan al-Jubaylī, a pupil of Ṭahtāwī’s: Bulaq 1293/1876), Barthélemy’s Voyage du jeune Anacharsis en Grèce (1788), and Louis-Philippe de Ségur's Histoire universelle ancienne et moderne (1821-22) ${ }^{462}$ The novel Télémaque, translated by Ṭahțāwī, was set in the world of the Iliad and Odyssey.

Many other Bulaq translations also touch on the ancient world. Of the two volumes of alJughräfiya al- 'umūmìya which are extant, one is devoted entirely to the history of geography, a large part of which is ancient history (it also mentions the role of the ancient and medieval Arabs). Other parts of Malte-Brun's text also often stray into descriptions of or allusions to the ancient world (we have seen an example of one, on the Druzes, which Ṭahțāwī excised from al-Ta 'rībāt al-shāfiya). European works on apparently modern topics, such as Voltaire's histories of Peter the Great of Russia and Charles XII of Sweden, or Robertson's History of Charles V, could also contain plenty of Classical allusions.

falāsifa) and Cairo 1328. The same work was published in 1854 at Smyrna (Imprimerie Daveroni et Sougiolli) in a bilingual French-Ottoman Turkish version, by Cricor Chumarian/Qrīqūr Qūmāryān. 461 Ibid., Appendix 1, no. 48, lists as translators Mustafā al-Zarābī, Abū al-Su'ūd, and Muhammad 'Abd alRāziq. He states that Tahtawi was corrector and wrote the introduction, and that Abu al-Fidā' was responsible for the section on the ancient Arabs, partly compiled from Arab authors. It was reprinted at Bulaq in 1282. cf. Choueiri, Modern Arab Historiography, 6 on Tahtawi's introduction. 462 An Imam in Paris, 289 and notes 1-5. 
In 1281/1864, the Egyptologist Mariette, employed by Khedive Ismail as director of antiquities, published an Aperçu de l'histoire d'Egypte both in French, and in an Arabic translation by 'Abdallāh Abū al-Su 'ūd. ${ }^{463}$ TTahțāwī himself set about an account of Ancient Egypt in later life, as the first part of a general history of Egypt. ${ }^{464}$ The Syrian writers had similar interests. The proceedings of the Syrian Scientific Society contain several contributions on the ancient world, from Salīm Shahāada's translation of Seneca's letters to Lucilius to Yūsuf Shalfūn on Greek and Egyptian legends (khurāfāt) to Jirjis Zwayn on the history of Syria. ${ }^{465}$ This interest continued in the 1870 s and 1880 s, with publications on the history of the Greeks, Romans and Macedonians, Babylon and Assyria. ${ }^{466}$ In 1859 Khalīl alKhūrī gave a lecture Kharābāt Sūriyya (The Ruins of Syria) to the Literary Club in Beirut; the following year this was printed as a short book at the Syrian Press. Its account of Tyre includes this passage:

Tyre was the most famous of the cities of the Phoenicians and the source of the civilisation (tamaddun) of the countries of the world; she drew to her bosom [members] of all peoples of the earth; her boast was that she was the inventor of the science of seafaring, the teacher of this craft to mankind, and the one who emboldened their hearts to the clash of the waves -[all] this by the power of a small boat. For this reason she was called the Queen of the Sea. All the merchants of countries near and far frequented her, in view of her goodly centre, the spaciousness of her harbour, and especially the good taste of her people and the correctness of their behaviour $[\ldots . .]^{467}$

Tyre, which is described in very similar terms in Télémaque, published serially in Khūrī’s

463 Auguste Bey Mariette, Aperçu de l'histoire d'Égypte : depuis les temps les plus reculés jusqu'à la conquête musulmane (Alexandria: Mourès, Rey, 1864).

464 Anwār Tawfìq al-Jalīl bi-Akhbār Miṣr wa-Tawthīq Banī Ismā '̄il (Bulaq, 1285); see Choueiri, Modern Arab Historiography, 8-15.

465 See Khūrī, A 'māl al-Jam iyya al- ilmiyya al-Sūriyya, 1868-1869, 100-120, 197-204, 181-4 respectively. 466 Jirjī Dimītrī Sursuq, Tārīkh al-Yūnān, Beirut s.n., 1876; Najīb Ibrāhīm Trād, Tārīkh al-dawla alMakdūniyya wa-l-mamālik allatī infașalat 'anhā, and Tārīkh al-Rūmāniyyīn min binā' Rūmā ilā talāshī alhukūma al-jumhūriyya, both Beirut: al-Mațba 'a al-Lubnāniyya, 1886; Jamīl Efendī Nakhla al-Mudawwar, corr. Ibrāhīm al-Yāzijīī, Tārīkh Bābil wa-Ashūr, Beirut: s.n., 1879.

467 Kharābāt Sūriyya (Beirut: al-Mațba'a al-Sūriyya, 1860), 36.

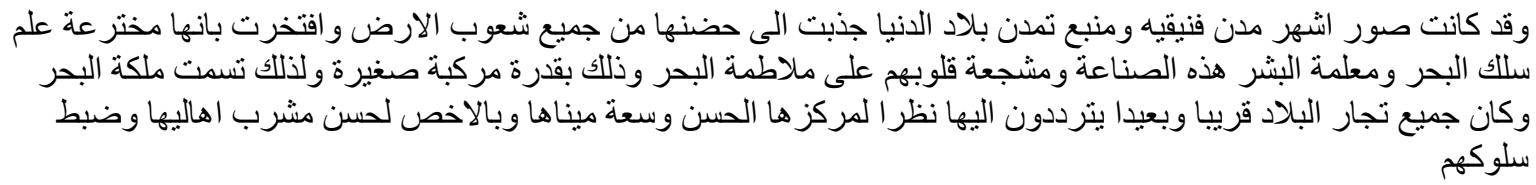

Ṭațāwī also mentions the story of the invention of seafaring at Tyre in Takhlīs al-ibrīz. 
Hadīqat al-akhbār between 1861 and 1867 in Ṭahțāwī’s translation, is only sixty miles down the coast from Beirut. As the history of Ancient Egypt and its original strong ruler, Sesostris, mapped conveniently onto the contemporary reality of Mehmed Ali's rule, so the ancient example of the trading entrepôt of Tyre might map onto nineteenth-century Beirut, then establishing itself as the principal port of Syria. The ancient civilisation which now-powerful Europe so admired had flourished in these lands; why might a modern civilisation, taking its example back from Europe, flourish there again? A century later, in the 1930s, Țāhā Husayn would argue this thesis in Mustaqbal al-thaqāfa fi Miṣr: but the foundations for his argument were already being laid a century earlier. ${ }^{468}$

\section{Great Men and Translatio Studii}

We have already seen an allusion of Tahțāwī's to Sesostris, the king of Ancient Egypt, in his second introduction to al-Ta 'rībāt al-shäfiya. Earlier in the same introduction, he had compared Mehmed Ali to three other great leaders, two ancient and one more recent:

the Caesar of his time and the Napoleon of his age; as if Alexander the Great had bestowed on him the port of Alexandria. ${ }^{469}$

As Youssef Choueiri has argued, many of the historical works translated by Ṭahțāwī and his associates can be seen as offering exempla based on the reigns of great military and political leaders: 'The frame of reference for such an ideal ruler [as Mehmed Ali] is contained in the biographies of illustrious men of the ancient and modern world, especially Alexander the

468 Mustaqbal al-Thaqāfa fì Miṣr (Cairo: Dār al-Ma ārif, 1938); The Future of Culture in Egypt, trans. Sidney Glazer (Washington, DC: American Council of Learned Societies, 1956).

469 Al-Ta'rībāt al-Shāfiya, 1: 3.

$$
\text { قيصر دهره ونابليون عصره فكانما اهداه اسكندر الاكبر ثغر الاسكندريه }
$$

Cf. the similar passage likening the Pasha to Caesar, Alexander and Frederick the Great, in Takhlīs al-ibrīz: An Imam in Paris, 354. 
Great, Louis XIV, Peter the Great, and Napoleon. ${ }^{470}$ All of these men - except, apparently, Louis XIV - were in fact the subjects of dedicated biography-histories translated into Arabic in the mid-nineteenth century. From Bulaq came translations of Voltaire's two histories of Charles XII of Sweden and Peter the Great of Russia - rival reforming monarchs on the edges of Europe. ${ }^{471}$ Part of Napoleon's Mémorial de Sainte-Hélène and the memoirs of one of his generals were also translated into Ottoman Turkish at Bulaq, along with Castéra's history of Catherine the Great. Țahțāwī read a biography of Napoleon in France, reckoned by Newman to be the 'hagiographical' work of Paul-Philippe de Ségur (1824). ${ }^{472}$ Meanwhile, the Piedmontese soldier Luigi Calligaris had written an Arabic history of Napoleon I (Paris 1856). This was later revised and republished in Beirut (1868) at the Mațba'a Wațaniyya, with additions on Napoleon's time in Egypt (probably from Niqūlā al-Turk's account). In the same year a History of Alexander the Great appeared from the same press. ${ }^{473}$

Roaming with their conquering armies across Europe, Africa and Asia, bestriding the world like so many Colossi, such figures could make the differences between continents seem less absolute. And as undoubted autocrats, but ones for whom European intellectuals had a great deal of respect, they called into question the notion that authoritarian rule was restricted to the 'despotism' of Asia.

470 Modern Arab Historiography, 7-8 and note 17; citing Rifā'a Rāfi 'Ṭahțāwī, Kitāb Manāhij al-albāb alMișriyya fì mabāhij al-ādāb al- 'așrīya, 2nd ed. (Cairo: Mațba 'at Sharikat al-Raghā'ib, 1912), 207, 214.

471 Histoire de Charles XII, roi de Suède, orig. 1731, Arabic: Mațāli 'shumūs al-siyar fì waqā' ' ' Karlūs althān̄̄ 'ashar, tr. Musțafā al-Bayyā', corr. R. al-Ṭahțāwī, Būlāq 1257. Histoire de l'Empire de Russie sous Pierre le Grand, orig. 2 vols., 1759, 1764, Arabic: al-Rawḍ al-azhar fĩ tārīkh Buṭrus al-akbar, tr. Ahmad 'Ubayd al-Ṭahțāwī, corr. R. R. al-Ṭahțāwī, Būlāq 1266. Shayyāl, Tārīkh al-Tarjama, Appendix 1, nos. 74 and 121. A Persian translation of the second, Tarikh-i Petr-i kabir, went into two editions: 1846 and 1895/6; On the French originals, see Síofra Pierse, 'Voltaire: Polemical Possibilities of History', in A Companion to Enlightenment Historiography, ed. Robert Sparling and Sophie Bourgault (Leiden: Brill, 2013), 170-3.

472 See Shayyāl, Tārīkh al-Tarjama, Appendix 1, nos. 7, 8, and 15; Johann Strauss, 'Türkische Übersetzungen Zweier Europäischer Geschichtswerke Aus Muhammad 'Alī’s Ägypten: Botta’s „Storia d'Italia“ et Castéra’s „Histoire de Cathérine“", ed. Einar von Schüler, Zeitschrift Der Deutschen Morgenländischen Gesellschaft Supplement VII, no. XXIII. Deutscher Orientalistentag (1985): 244-58; An Imam in Paris, 289 , n. 6.

473 Colonel Chevalier Louis Calligaris, Kitāb Sīrat Napulyūn al-Awwal (Histoire de l'Empéreur Napoléon), 1st ed. (Paris, 1856); Kitāb Tārīkh Nabulyūn Bunabārtā al-Awwal, 2nd ed. (Beirut: al-Mațba 'a al-wațaniyya, 1868); Anon., Tārīkh Iskandar Dhī al-Qarnayn al-Makdūnī (Beirut: al-Maṭba a al-wațaniyya, 1886). These are given as from al-Maṭba 'a al-wațaniyya, 1868, by Boustany, 'Imprimés Non Périodiques', 2: 343. 
All of these elements come together in Țahțāwì's introduction to his translation of Télémaque, Mawāqi al-aflāk fi waqā’i i Tilīmāk (1867). This includes a most interesting digression into Greek mythology (mìthulüjiyā) and the problematic questions of multiple deities or spirits, and their unions with humans, which is introduced by way of Hercules and Alexander the Great. After mentioning that Telemachus is the son of Ulysses, Tahțāwi makes a digression on the subject of Hercules - who some claim is the same person as Ulysses. Ṭahțāwī denies this link and instead links Hercules to Alexander the Great/Dhū al-Qarnayn. We can find other examples of Tahțāwī's interest in Alexander: in Takhlīṣ al-ibrīz he states that he translated, in France, an extract from an ancient history book about Alexander the Great, and mentions him elsewhere. ${ }^{474}$ There is also plenty of evidence for Mehmed Ali's self-comparisons with Alexander in particular: Afaf Lutfi al-Sayyid Marsot mentions, 'Two of his sons were named Iskandar, i.e. Alexander, for whom the father had a great deal of admiration and about whom he read much'. ${ }^{475}$

Early in the introduction to Mawāqi al-aflāk Mehmed Ali is compared favourably to the kings of ancient Egypt, and the early Caliphs, as well as Ulysses and Telemachus. ${ }^{476}$ His rule and that of Ibrahim is linked to the glory of Egypt. ${ }^{477}$ This glory is one of both power and culture:

His [Mehmed Ali's] days are days of sciences and letters, scholars and writers, armies and soldiers, champions and heroes. ${ }^{478}$

The association between cultural and military prowess is made clear again in the first wațaniyya poem included in the introduction. Tahțāwī writes of the sons of Egypt:

474 An Imam in Paris, 299; 131, 134, 135, 174, 354.

475 Egypt in the Reign of Muhammad Ali (Cambridge: Cambridge University Press, 1984), 81.

476 Mawāqi al-aflāk, 2-3.

477 Ibid, 15 ('man a 'àdā li-Miṣr fakhrahā al-sinnī’).

478 Ibid, 6 .

ايامه ايام علوم و اداب و علمآ وكتاب وجيوش وجنود وليوث و اسود 
Their taste is innate, their standing is great,

They are renowned for the honour of civilisation

Their soldiers are valiant, their hearts are iron,

Their enemies are driven away, or rather wrapped in a shroud! 479

In the second wataniyya, he again mingles cultural and military glories:

The schools of Egypt have returned, the numbers of their pupils has increased $[\ldots]$

We order our soldiers in a wonderful way $[\ldots] .^{480}$

This wonderful 'ordering' of the Egyptian armies was achieved with the help of techniques borrowed from Europe, and European advisors. Such features remind us of Țahțāwī’s place in a local, Ottoman-Arab-Egyptian hierarchy, as a servant of Muhammad Ali's dynasty - one which had, for a time, a significant imperial reach. Much of Ṭahțāwī’s own work in education and translation was designed to aid the dynasty, and Egypt, by bringing across knowledge from Europe. In her study of translation into Arabic during the Nahda, Shaden Tageldin refers to the close link between translatio imperii (the transfer of power) and translatio studii (the transfer of knowledge) in French writers such as Joachim du Bellay. ${ }^{481}$ We cannot fail to see the similarity in Tahțāwī. There was perhaps no question of Egyptian power superseding European power - as there was, for du Bellay, the prospect of France inheriting and eclipsing the power of Athens and Rome. But there was the prospect of Muhammad Ali's dynasty, by making use of knowledge and techniques from Europe, being 479 Ibid, 14.

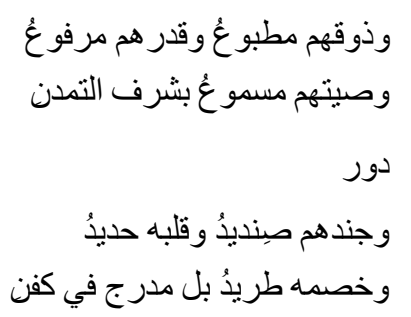

480 Ibid, 17.

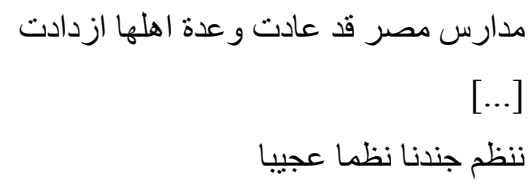

481 Disarming Words, 129-130. 
able to rival former rulers of Egypt, and other non-European rulers. Sciences and letters, 'civilisation' (tamaddun), were a part of the dynasty's claim to power and the right to power - just as attacking the dynasty's 'civilisation' could be a justification for limiting its rule. Not long before his own intervention against Muhammad Ali's forces in Syria, the British Foreign Secretary Palmerston wrote disparagingly of Muhammad Ali’s 'boasted civilisation of Egypt' as 'the arrantest humbug'. ${ }^{482}$

Against Palmerston and others, Ṭahțāwī sought to align Khedivial Egypt with Europe, the ancient world of heroes like Alexander; the Arab Caliphs. But another face of Egyptian 'civilisation' was turned towards the Egyptian peasantry, the conscript soldiers being so wonderfully 'ordered' (as Khaled Fahmy has shown) and Egypt's imperial possessions, such as the Sudan. ${ }^{483}$ It was here that Ṭahtāin̄ made the translation of Télémaque while in exile, a circumstance he bitterly regrets:

It was my fate to go to the country of Sudan - there is no escaping the fate God decrees. I spent a period there, my ardour dampened and my talent motionless, in that tedium, until I was almost destroyed by that hellish region, blazing with heat and poisons, and the ferocious elephant of the Sudan had nearly swallowed me up with its trunk. ${ }^{484}$

In this wilderness, his only pleasure comes from arabizing ( $t a^{\prime} r \bar{\imath} b$ ) Telemaque. The Arabic language and the European text Télémaque are thus allied, as pleasure-giving and refined; the Sudan is hellish and tedious. As Troutt Powell has pointed out, he expressed still more violent emotions towards the Land of the Blacks in a poem written in his exile. Here he describes the bestial customs of the Sudanese and concludes:

If it were not for the white Arabs, they would be

$$
\text { Blackness in blackness, in blackness }{ }^{485}
$$

482 Letter to Granville, quoted in Lutfi al-Sayyid Marsot, Egypt in the reign of Muhammad Ali, 243. 483 Fahmy, All the Pasha's Men.

484 Mawāqi 'al-aflāk, 4.

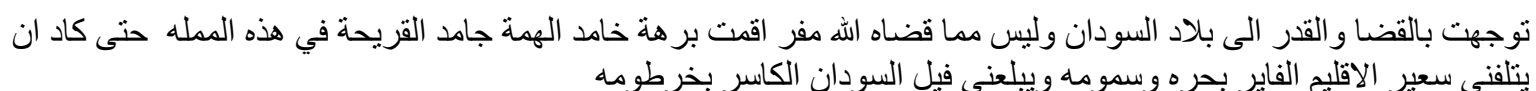
485 Ode included in Manāhij al-albāb, 267-8. Cited in Troutt Powell, A Different Shade, 54. 


\section{Through Western Eyes: the Foreign News Reports of Hadīqat al-akhbār}

Egyptian and Syrian writers' eagerness to identify with Europe, and with Europe's Ancient models, in addition to the attitudes we have seen here, and in Chapter 2, towards the lower orders of their own countries and imperial possessions like the Sudan, may have influenced their attitudes to Europeans' doings abroad. We have noted some instances of Țahțāwī's awareness of the possibility of European encroachment on Syria, and his support for the Ottoman Empire against attempts to detach some of its provinces by European powers or those inspired by them (the Greeks). But even in some of these cases close to home, let alone further afield, Arab intellectuals in these decades seem to have regarded European conquests of various 'native' peoples with either approval or insouciance. In the light of the future history of European imperial domination in the Arab world these views can appear absurdly shortsighted: the European occupations of India or Algeria were seen as in no way ominous for Egypt or Syria. But this peculiarity can to some extent be explained by two circumstances.

First, European ideology in the mid-century could be more benign and optimistic than in the later high imperial era. 'If England always had the biggest empire,' wrote Victor Kiernan, 'it was the least militarized among the big nations, and for a long time its faith was pinned to free trade and peace. To this faith the imperialist creed [of the later high imperialism] came as a painful challenge, a relapse into the mentality of bygone days. ${ }^{486}$ He claimed elsewhere, 'Mid-century Europe was more enlightened in some ways than either the earlier Europe of the time when British conquest in India began, or the later, when the general scramble for

$$
\text { لو لا البيضَ من العرب لكانوا سو ادأ في سوادٍ في سوادٍ }
$$

486 Marxism and Imperialism, 3. 
Africa took place. ${ }^{487}$ Free trade and peace in the age of Palmerston, even if they were overwhelmingly to be carried out under European rule or supervision and in largely European interests, appeared to have more to offer non-Europeans, or at least non-European bourgeois and bureaucratic elites, than the territory-grabbing empires of the 1880 s and 1890s. It was only in this later period that 'imperialism' as such was defined as a problem, and that analyses and critiques of it began to emerge, starting with J. A. Hobson. ${ }^{488}$ The alternatives to European rule could appear mere relapses into backwardness, ignorance and savagery - as most of the Indian bourgeoisie appears to have regarded the Indian Rebellion or 'Mutiny' of $1857 .{ }^{489}$

A second, related point is that Arab intellectuals were in this period largely dependent on the Europeans themselves for knowledge of their activities in the non-European world, beyond their own countries. This could be the case even for places rather near to home, such as parts of the Ottoman Empire. The fact that they tended to see Europe as very much the centre of the world of events, moreover, was not merely an adoption of Eurocentric views, but a reflection of the reality of the mid-nineteenth-century world, in which matters affecting the non-European world were to a great extent transacted among, or with, Europeans.

These features can be seen from a sampling of the news coverage in that pivotal Beiruti newspaper, Khalīl al-Khūrī's Hadīqat al-akhbār. In the manner of its organisation, this coverage offers a good instance of how Arab-Ottoman intellectuals organised the world in their own imaginations. The first section of news to appear, in Hadīqat al-akhbār - on the front page, and occasionally preceded by editorial announcements or official Ottoman

487 The Lords of Human Kind, 208.

488 Kiernan, Marxism and Imperialism, 1-3.

489 Benoy Ghose, 'The Bengali Intelligentsia And The Revolt', 103-118 in Mohammad Ashraf and Puran Chandra Joshi, eds., Rebellion, 1857: A Symposium (New Delhi: People's Publishing House, 1957), 257270. 
proclamations - is a 'political summary' (khulāṣa siyāsiyya), which usually continues onto the following page or two. This is a précis evidently written by the editors, but generally devoted to European events and reproduced from European papers. In one issue, it begins with a self-advertisement in just these terms:

Whoever now wishes to read the truth of the current conditions of politics in Europe, let him scrutinise this summary of ours: there is no doubt that he will be quenched from it just like one who drinks from the springs of the most approved European papers $[\ldots . .]^{490}$

At the end of this 'summary' there often appears, on the second (inside) page of the newspaper, a report of Ottoman official news: appointments, announcements and the like. This is followed by 'domestic news' (al-akhbār al-dākhiliyya) and then 'foreign news' (alakhbār al-khārijiyya). This division in Arabic newspapers, clearly derived from European ones of the era, apparently goes back to al-Waqa ' $i$ ' al-Mișriyya in 1828. Ami Ayalon claims that al-Waqa ' $i$ ' al-Mișriyya was the first Arabic paper to carry foreign news: drawn, 'as the paper acknowledged, "from the jurnālāt of Europe." ${ }^{491}$ For Hadīqat al-akhbār, the 'domestic' category covers such places as Beirut, Istanbul, Damascus, Tripoli, Antakya. These reports are generally derived from the newspaper's own correspondents, or sometimes from official Ottoman sources. 'Foreign' news covers everything else, and like the 'political summary' is generally précised or translated from European newspapers. These are generally mainstream or official papers: the 'Austrian Gazette', L'Indépendance Belge, Napoleon III's official Le Moniteur, the Morning Herald or Times of London. ${ }^{492}$

Eurocentrism is then evident in two senses. First, the world events which are seen as the

490 Hadīqat al-akhbār 57, 24 February 1859.

$$
\begin{aligned}
& \text { من ار اد ان يقف الان على حقيقة احوال السياسة الحالية فى اوروبا فليدقق النظر فى خلاصتنا هذه ولا شك انه يرتوى منها كمن }
\end{aligned}
$$

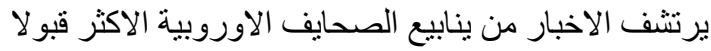

491 'Sihafa: The Arab Experiment in Journalism', Middle Eastern Studies 28, no. 2 (1992): 261.

492 Elizabeth Holt offers evidence for other papers in the early 1870s: 'Among the journals cited by al-Najāh in 1871 are La Liberté, Le Moniteur universel, La Turquie, L'Indépendance Belge, L'Univers illustré, La Cloche, Paris journal, Figaro, Gaulois, La Couronne de Paris, La Patrie, and The Times. In addition to publications of the Roman Catholic Church, al-Bashīr in 1870 and 1871 frequently references Le Moniteur 
most important are those happening in Europe: other parts of the world, including the 'internal', domestic lands, come second. Second, the information on these events, as well as on most of the world outside Europe, is derived from European sources - moreover respectable, bourgeois European papers like The Times or the official Le Moniteur. This is only mitigated in the case of the reports from 'domestic' correspondents, within the ArabOttoman countries themselves, and even here, events within the Ottoman Empire are sometimes reported from foreign papers, or seen from the perspective of 'Eastern Question' negotiations within Europe.

These aspects become clearer when we look in more detail at the news coverage in a few numbers of Hadīqat al-akhbār over June to December 1858: both early in the life of the newspaper, which started on 1 January 1858 , and a time of interesting political events internationally. Some of the leading news items in the 'political summary' are devoted to European diplomatic disputes (and hence potential wars): an incident involving the arrest of two Englishmen in Naples, the French ship Charles-et-Georges, seized by the Portuguese for slave-trading off Mozambique, a Naples-Austria dispute. ${ }^{493}$ Hadīqat al-akhbār also covered the dispute between the Ottoman Porte and Montenegro, along with negotiations over the status of Wallachia and Moldavia (then separate principalities under Ottoman suzerainty). Some of these events are reported from the Ottoman official newspaper (Takvim-i Vekayi, published from 1831), others from European papers, and many concern events relevant to the Ottoman Empire but taking place in European capitals. ${ }^{494}$ There are reports on the British

universel, suggesting it was available with some regularity in early 1870 s Beirut. Daniel Bliss mentions reading copies of several foreign papers in Beirut, among them The Observer, The Congregationalist, and The Record. See Letters from a New Campus, 1873-74 (Beirut: American University in Beirut Press, 1994), 55; 62. Additionally, journals of the period regularly mention The Levant Herald, and cite Arabic journals published outside Beirut, such as al-Jawä 'ib, Wādì al-Nīl, and al-Furāt.' 'Narrative and the Reading Public', 43-4, n. 19.

493 Hadīqat al-akhbār 24, 19 June 1858; 50, 18 Dec. 58; 51, 25 Dec. 1858.

494 Hadìqat al-akhbār 26, 3 July 58 and 24, 19 June 1858 both carry reports on Montenegro from European papers and the Ottoman official paper; see also no. 25, 26 June 58 for a report on the Paris Convention then deliberating on the 'Eastern Question', and the Wallachian majlis's thanks to the British House of Commons, and an essay on the disputed provinces. 
blockade against the slave trade, and seizures of US ships: some support is expressed for the blockade, but there is also the fear of enmity resulting from this obstruction of the USA's freedom of trade. ${ }^{495}$

A large amount of the coverage is given to the imperial affairs of European nations, mainly the British, French and Russians. The British were still in the last stages of suppressing the Indian 'Mutiny' which had broken out in 1857: several reports cover this, all apparently derived from the British (or British Indian) press. The reader of Hadīqat al-akhbār would have learnt on 19 June 1858 that the British people and Parliament were much concerned with the policy of Governor-General Canning in India, especially over Oudh (this was 'Clemency Canning', whose treatment of Indian rebels was seen as far too lenient by the Great British public), and that the British were also considering which troops to use against the rebels, those of Bombay and Madras being reckoned exceptionally loyal. ${ }^{496}$ The following week there was another report on troop numbers in India, as well as one stating that Parliament was considering new proposals for the government of India. ${ }^{497}$ In December, a large section dedicated to 'India' informed readers that these new plans were now realised: Hadīqat al-akhbār reproduced in full, from the Bombay Telegraph and Courier, Queen Victoria's Proclamation to the Princes, Chiefs and the People of India, which announced the end of the East India Company and the start of direct British rule over India. It also translated in full two petitions responding to Her Majesty and welcoming this happy event, one signed by 'over three thousand' citizens of Bombay, the other by the President and Members of the Bombay Presidency Association. ${ }^{498}$ This appears, then, to represent the Bombay bourgeois opinion which, like that of Bengal, was thoroughly opposed to the

495 Hadīqat al-akhbār 25, 26 June 1858 (noting that not all US states have freed their black population); and 26, 3 July 1858 (for the Times's disapproval of seizing US ships).

496 Ibid, 24, 19 June 1858. 497 Ibid, 25, 26 June 1858. 498 Ibid, 51, 25 Dec. 1858. 
rebellion (though it also sided with Canning and moderation). ${ }^{499}$ A September number had also carried a report stating that military operations against the rebels had stopped due to the heat, but that the rebels were so weakened that this respite would do them little good. ${ }^{500}$ The accounts of the Rebellion in Hadīqat al-akhbār appear to be pro-British, even by the standards of the European press outside Britain, if we can go by the results of the survey of foreign reports of the Rebellion in Ashraf and Joshi's Rebellion 1857: A Symposium. The French press was generally anti-British, if for nationalistic rather than anti-imperialist reasons. The Russian press, even though it apparently depended, like Hadīqat al-akhbār, on British reports of Indian events, often expressed sympathy with the Indian rebels; as, it seems, did many Italian writers of the time. ${ }^{501}$

While the British were crushing the Indian 'Mutiny', the French were busy pacifying Algeria. French forces had taken Algiers in 1830, while Ṭahțāwī was in Paris. In Takhlị̣̄ al$i b r \bar{z}$, he mentions the event merely as an episode in his narrative of the 1830 revolution - a French, metropolitan narrative. ${ }^{502}$ As we have seen, he notes the French occupation of Algiers briefly in al-Ta 'rībāt al-shāfiya, while maintaining that the North African provinces are still really part of the Ottoman Empire. In 1858 Hadīqat al-akhbār had a correspondent in Sétif: his report dated 3 June, classed under 'foreign news: the West' (al-gharb), states that Prince Napoleon (cousin of the Emperor Napoleon III) was to assume control of Algeria as Minister of Algeria and the Colonies. ${ }^{503}$ A report in December confirms this new arrangement, and offers a brief account of Algeria's division into areas of military and 499 Veena Naregal, 'The Mutiny in Western India: The “Marginal' as Regional Dynamic,' 169-88, in Crispin Bates ed., Mutiny at the Margins: New Perspectives on the Indian Uprising of 1857, Volume I: Anticipations and Experiences in the Locality (New Delhi: SAGE, 2013), 173; Benoy Ghose, 'The Bengali Intelligentsia And The Revolt', 103-118, in Ashraf and Joshi, Rebellion, 1857; Kiernan, The Lords of Human Kind, 48.

500 Hadīqat al-akhbār 37, 18 Sept. 1858.

501 Charles Fournian, 'Contemporary French Press', 313-321; Liliana Dalle Nogare, 'Echoes of 1857 in Italy', 322-331; P. Shastiko, 'Russian Press on 1857', 332-336, in Ashraf and Joshi, Rebellion, 1857.

502 Rifā'a al-Ṭahțāwī, An Imam in Paris, 326 ff. He also mentions having read a travelogue of Algeria during his time in Paris - presumably a European one: ibid., 290.

503 Hadīqat al-akhbār 25, 26 June 1858; also mentioned in no. 24, 19 June 1858. 
civilian control, as well as an expedition against some Arab tribes who had failed to pay their taxes. ${ }^{504}$ We may also reproduce a brief notice from early 1859 :

The West

The newspaper Le Moniteur has published a letter of 21 December from His Excellency General MacMahon, stating that he has chastened and subdued the band of Arabs (firqat al- 'urbān) who rose up at the instigation of a rebellious shaykh. ${ }^{505}$

The June 1858 report gives an account of the expansion of agriculture in the Sétif region under the aegis of the Compagnie génevoise des colonies suisses de Sétif. ${ }^{506}$

The December issue also carried an account of the French-Spanish punitive expedition to Cochin China (Vietnam). ${ }^{507}$ This was itself a side-effect of the Second Opium War, which involved all the great European powers against China, and was frequently reported in Hadīqat al-akhbār . In July, there was a report of fears that the Chinese might retake Canton (after the resumption of hostilies when the Xianfeng Emperor rejected the disadvantageous treaties of Tientsin and Aigun). ${ }^{508}$ But in September comes news of peace (although this was not in fact finally concluded until October 1860). A large part of the 'political summary' of one issue is devoted to this event, and the happy consequences expected from it, opening:

The most important piece of news that has come to us lately is the concluding of the peace treaty between the Chinese Empire and the European states in a way that the public good has hoped for some time. We have seen that the work of the envoys in China has been crowned with the blossoms of success and led to the progress of the world of trade (tarqiyat 'ālam al-tijāra), expansion of the general good (ittis $\bar{a}$ ' alkhayr al- 'âmm). For the Chinese majesty has awakened from its slumber and hurried to please the Great States with what they requested. This important piece of news is

504 Ibid, 50, 18 Dec. 1858.

505 Ibid, 57, 5 Feb. 1859.

$$
\text { التى قحيفة المونيتور اشهرت شتيخ متمرد رسالة فى إ ك ك من صاحب السمو الجنر ال ماك ما هون تخبر بانه قد قاصص وطيع فرقة العربان }
$$

506 For this company, see Claude Lützelschwab, La Compagnie Genevoise Des Colonies Suisses de Sétif (1853-1956): Un Cas de Colonisation Privée En Algérie (Bern: Peter Lang, 2006).

507 Hadīqat al-akhbār 50, 18 Dec. 1858.

508 Ibid, 26, 3 July 1858. 
mentioned in the paper L'Indépendance [Belge.] $]^{509}$

The report goes on to list the details of the peace, essentially that of the Treaties of Tientsin and Aigun - greater war compensation to Britain and France, the opening of Chinese ports to Western trade, Chinese acceptance of Western diplomats - and remarks what a great step forward this is for the Western powers, especially Britain. The December issue announces one of the bright prospects that has been opened up by the prospect of peace on such favourable terms (to the Western powers). A large part of the 'political summary' is devoted to Russian plans for the lands ceded to it at Aigun, north of the Amur River: a railway linking these to Russia is planned, the river is mentioned as capable of carrying shipping, and another port in the area, discovered by a recent Russian expedition, as free of ice for all but four weeks of the year. The new lands of the Tsar's Empire are described as being capable of growing 'all kinds of grains and fruit', as well as containing coal mines and possibly precious metals. There is also a report from the China Mail (Hong Kong) on Lord Elgin's new treaty with Japan, and notes that the Russians have a similar treaty - all this operating to the advantage of the European powers in opening up China for trade and exploitation..$^{510}$

A number of provisional conclusions can be derived from this sample. First, its coverage, though mainly taken from European sources, was global in reach. The 'rediscovery' taking place in these pages - as to some extent in the geography books dealt with above - was not, in the words of Abu-Lughod's title, the 'Arab Rediscovery of Europe' alone, but a discovery and rediscovery of the globe, although this globe was European-dominated. Second, a 509 Ibid, 37, 18 Sept. 1858.

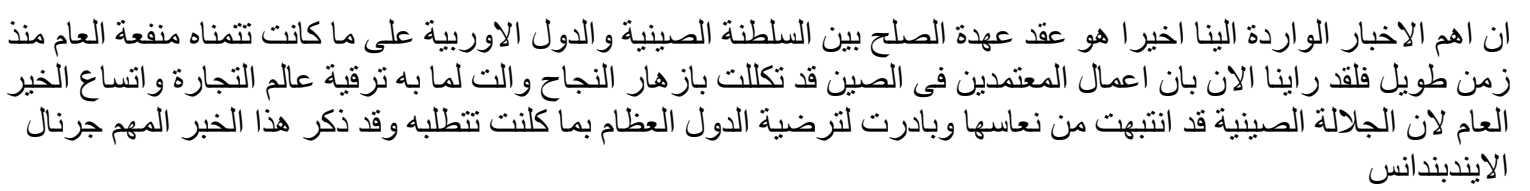
510 Ibid, 48, 4 Dec. 1858. 
similar bias is revealed to that of the translated geography books: the newspaper coverage of Europe and most of the rest of the world was taken from European sources (moreover, often official or semi-official ones), but for the Arab-Ottoman countries such sources as the Ottoman official gazette or reports of Arab correspondents were used. Third and most interestingly, the light in which the globe, and European expansion into its non-European parts outside the Arab-Ottoman lands was seen, was the light of capitalist 'progress'. Punitive expeditions, compelling China to submit to Western exploitation, the crushing of the Indian Rebellion, all tended to be seen as acts to increase the general peace and prosperity. European involvement in these countries was evidently stimulating material progress - railways, agriculture, the exploitation of mineral resources - in ways that Beiruti businessmen could understand. The reports on the Compagnie génevoise's expansion of agriculture in Algeria, on the possibilities of trade with China and of the new Russian lands north of the Amur run alongside a long article on electricity, references to the opening of the first transatlantic telegraph between Britain and the USA and the discovery of gold-mines in Colombia, an item on technical innovations of the water-carrying company of Odessa. ${ }^{511}$ The actions of Europeans abroad were very much part of the mood of celebration, almost wonder, at the marvels of technological and commercial progress and invention, as well as geographical discovery, which Elizabeth Holt refers to in 1870s Beirut: 'consumer goods, advances in science, and an air of the fantastic'. ${ }^{512}$

\section{Conclusion}

By the time Hadīqat al-akhbār was reporting on the Second Opium War in 1860, much had

511 Ibid, 25, 26 June 1858; 37, 18 Sept. 1858; 48, 4 Dec. 1858.

512 'Narrative and the Reading Public in 1870s Beirut', 68-9. 
changed in Nahda writers' consciousness of their place in the world since TTahțāwī first read Depping's Aperçu thirty years previously. His sense of the new and remarkable vistas opened up by European geographical knowledge, and of how this knowledge could be applied in the interests of the Alid state, had been overtaken, swallowed up perhaps, in a widening and deepening awareness of the world at large - both contemporary and ancient - as the pace of translation and exchange of information quickened through these decades. The readers of Hadīqat al-akhbār aspired to be citizens of this, admittedly European-dominated, world, firmly within the camp of 'civilisation' as opposed to 'barbarism'. And as they looked around the horizon they could see plenty of evidence for the efficacy of this view of things, as the onward march of capitalist progress through the quarter-century from 1848 to 1875 , Eric Hobsbawm's 'Age of Capital', proceeded without serious impediment. Observing this, they could derive from it, we may suggest, a powerful confirmation of their own 'civilising' projects or those of the reforming states - from the creation of new cultural and educational institutions, to the Ottoman Tanzimat reforms, to the penetration of European business interests into Syria and Egypt. They were marching in step with the world: and it was perhaps easy to think that those who stood against the new order - recalcitrant Chinese mandarins, rebellious Indian sepoys, peasant rebels in Kisrawan or violent urban crowds in Damascus - would inevitably be swept aside. This implied, evidently, a far more positive attitude towards Europe than that of later anti-colonial movements. Europe, including European imperial domination, was on the side of civilisation, prosperity and order; rebellions against it were on that of chaos, ruin and barbarism.

But this did not imply merely a capitulation to European values or intellectual authority - as the postcolonial scholars I engage with above - Timothy Mitchell, Lisa Pollard, and Shaden Tageldin - have tended to argue. I hope I have shown here that there are many examples of 
independence, autonomy, interests different from and at times opposed to those of Europeans, to be found in the literary record of these decades. These must be placed alongside the evidence - which undoubtedly exists - of cultural 'dependency' on Europe. They may be seen, if we wish, as two sides of a dialectic, of a cultural movement both unavoidably bound to and distinct from Europe, or 'the West'. Moreover, this dialectic did not take place in the head alone, but was, in both its aspects, deeply involved in the wider social dynamics analysed in Chapter 1, and to the position of these particular Arab-Ottoman intellectuals, or bureaucrats, or capitalists, in relation to Europeans and to other social classes in their own societies. The two sides of the cultural dialectic correspond to the two equally contradictory sides of their social position. As professional groups or as classes - merchants trading with Europe, newspaper editors, educators and translators supplying Western-derived knowledge - the whole position of 'men of the Nahda' in their own societies depended on contact with Europe, and with the rest of the European-dominated world. In a society rigidly isolated from outside or European influences, such groups would not even have come into being. On the other hand, unrestrained foreign domination, and especially direct colonisation, could not be in their interests: Syrian merchants might be forced out of business by British or French, cultural institutions dominated by foreign missionaries, top places in the bureaucracy monopolised by Europeans. These were all real dangers in different contexts through the nineteenth century. And so we find their characteristic mode, within the confines of this dialectic: accepting what Europe offered, but altering it to suit their own purposes; accepting the overall domination of Europe (and locally, of course, of Ottoman states), and negotiating the best position they could within this. Nor, in this, were they wholly unsuccessful, as some of the examples presented here go to show.

Here I may cite a suggestive example from a comparable imperial situation. One of the 
examples of Hadīqat al-akhbārr's foreign news coverage, cited above, was the translation of

Victoria's Proclamation of 1858, and of the loyal replies to it by citizens of Bombay. This

'loyalty' of the bourgeoisie and intellectuals during the Indian Rebellion perplexed later

Indian nationalists: were they, in terms similar to those of Tageldin or Mitchell, simply

'deluded' or 'echoing' the British rulers? In 1957, an Indian Marxist critic thought otherwise.

The loyalty of the Bengali intelligentsia was [...] conditional. So long as the British rulers acted in favour of the class interest of the intelligentsia, their loyalty was assured but not otherwise. [...] It would be unjust and untrue to say, therefore, that the Bengali intelligentsia of the eighteen-fifties merely echoed the sentiments of their rulers in expressing their hostile attitude towards the rebels. They had their own point of view and own say in the matter.

The new middle-classes created under British rule saw no hope in the 1857 revolt. Their hope lay in the success of the middle-classes in Europe and in England, in the political, economic and social fields. They found the representatives of these "middle-classes" in the British rulers and thought it more prudent in their own classinterest to follow them $[\ldots . .]^{513}$

I would argue that the new bureaucrats of Egypt, as well as the bourgeoisie of Beirut, had a similar attitude to European rule around the world and to the use of European knowledge and techniques in their own activities. The element of 'dependency' on Europe in their own class position, analysed in my first chapter, inclined them to see intensified contact with Europe as indispensable. As it later proved, they could accept this - like the Bengali or Bombay middle classes - even at the price of imperial rule by Europeans, but in fact in the mid-nineteenth century, under the Ottoman and Alid regimes, even this was not necessary, and did not appear inevitable. The Syrian merchants - or the Baghdadi Jews in India - would prosper rather well under European empires; the new breed of bureaucrats and technicians in Egypt or the Ottoman Empire owed their indispensability to their European-derived education and skills. This had its other side: Syrians also had an edge over their European competitors due to their greater local knowledge; and Muslim Egyptian or Ottoman bureaucrats could supplant Europeans, renegades or Syrian or Greek Christians due to their greater ability to

513 Benoy Ghose, 'The Bengali Intelligentsia And The Revolt', 103-118 in Ashraf and Joshi, Rebellion, 1857, $117,130$. 
adapt Europe-derived knowledge to local circumstances; and we can relate this to their reluctance to capitulate to Europe entirely.

Economically and politically as well as culturally, the position of these 'new social classes' of the Arab-Ottoman world was confined between the twin extremes of total dependence on Europe, and rejection and isolation. In assuming them to be agents or 'deluded' dupes of imperialism, postcolonial critics, remaining on the terrain of the history of ideas, have not given sufficient weight to their class position and interests. When Tahtậwī adapted European geography books for Mehmed Ali's state apparatus, he knew what he was doing, and was duly rewarded for it. Like the Bengali middle classes, the 'men of the Nahda' were aspiring to the condition of 'civilised' citizens of a world made safe for capitalism and the 'modern' state, largely by European efforts, but also by some of their own. Their consciousness of their own place in the world, in the scale of civilisation and barbarism, on Burke's 'Great Map of Mankind', was inseparable from their position in class and imperial relations, both bound to and distinct from Europe. 


\section{Chapter 4}

\section{An Arab Utopian}

Would that I had a trumpet-voice, - it should arouse this whole country. I would sound a warning in the ears of the slumbering, that the dawn has come, and we must be up and doing.

John Wortabet, 1852

I heard a voice resounding through the clouds, calling: 'Bear tidings, bear tidings, o ancient desert of Aramea; and rejoice and be glad, o Shahbā' of Syria: behold kingly Providence coming to you!'

Fransīs Marrāsh, 1865

\section{Placing 'Utopia'}

The use of the term 'utopia' in relation to the nineteenth-century Arab Nahda requires some explanation. The term itself, meaning in Greek 'no-place', of course originated with Sir Thomas More's Latin work of that name, in 1516. Since then it has come to stand for a tradition, generally seen as a more or less Western or even West-European one, deriving from or influenced by More's work. ${ }^{514}$ It has also been applied, retrospectively, to older traditions of thinking or writing: most often to works belonging to the 'Western' heritage: the lineage which goes back to Plato's Republic, that which goes back to St Augustine's City of God, or, in a different place on the social scale, medieval dreams of the Land of Cockaygne, popular millenarianism. But non-'Western' utopias have also been discovered, in ancient and modern times: in Confucianism, ${ }^{515}$ in Japanese literature of the nineteenth century, ${ }^{516}$ in al-

514 Frank Edward Manuel, Utopian Thought in the Western World (Cambridge, Mass: Belknap Press, 1979). 515 William A. Callahan, 'Confucian Harmonizing: Utopia, Dystopia and Heterotopia in Chinese Thought', Journal of Comparative Asian Development 2, no. 2 (2003): 233-57.

516 Yoriko Moichi, 'Japanese Utopian Literature from the 1870 s to the Present and the Influence of Western Utopianism', Utopian Studies 10, no. 2 (1999): 89-97; Alfred Owen Aldridge, 'Utopianism in World Literature', Tamkang Review XIV, no. 1 (Autumn 1983): 11-30; Seiji Nuita, 'Traditional Utopias in Japan and the West: A Study in Contrasts', in Aware of Utopia (Conference on Utopia in Comparative Focus), ed. David W. Plath (Urbana: University of Illinois Press, 1971), 12-32. 
Fārābī’s Virtuous City (itself bearing an obvious relation to Plato). ${ }^{517}$ Many also see science fiction as a late, contemporary form of utopia. ${ }^{518}$ Beyond these various 'literary' utopias, which presuppose at least shared aspects of literary form, traces of utopianism, or utopia-asideal, have been discovered still more widely. 'Utopia' could stand, for Karl Mannheim, as the counterpart to 'ideology' (any form of social thinking which sought change, as opposed to stasis) - an opposition later reworked by Fredric Jameson; ${ }^{519}$ for Franco Venturi, it could stand for political republicanism; ${ }^{520}$ for others it could, apparently, come to mean social change or 'reform' of almost any kind. ${ }^{521}$

The range of reference is itself suggestive, but it is necessary to define in what senses we can speak of 'utopia', with reference to the Arab nineteenth century. In the first place, we may agree that human cultures have long been in the habit of creating images of a better, even a perfect life; and that this propensity is in no sense confined to the 'West', or to the educated circles of the Plato-and-Augustus traditions. If 'utopia' can be applied retrospectively to Plato's Republic, it can certainly be applied also to Fārābī’s Virtuous City; and there seems no obvious reason why it should not be also to Cockaygne or millennarian dreams. On the other hand, the traditional, Anglocentric, caesura which we generally find in accounts of 'utopia', with Sir Thomas More's annunciation both of the term and of a different literary mode, is I think justified. For contemporaneous with More, for the first time, actual social change appeared to be reaching a level that was at least comparable with that which would

517 Dominic J. O’Meara, Platonopolis: Platonic Political Philosophy in Late Antiquity (Oxford: Clarendon, 2003).

518 Raymond Williams, 'Utopia and Science Fiction', in Culture and Materialism: Selected Essays, 11 (London: Verso, 2005), 196-212. Darko Suvin, Metamorphoses of Science Fiction: On the Poetics and History of a Literary Genre (New Haven: Yale University Press, 1979) sees utopia, rather, as a subspecies of science fiction.

519 Karl Mannheim, Ideology and Utopia: An Introduction to the Sociology of Knowledge (London: Routledge \& Kegan Paul, 1949); Fredric Jameson, The Political Unconscious: Narrative as a Socially Symbolic Act (London: Methuen, 1981), Ch. 6 'Conclusion: The Dialectic of Utopia and Ideology'.

520 Franco Venturi, Utopia and Reform in the Enlightenment (London: Cambridge University Press, 1971).

521 Shiping Hua, Chinese Utopianism: A Comparative Study of Reformist Thought with Japan and Russia, 1898-1997 (Washington, DC: Woodrow Wilson Center, 2009). 
be required to realise any previous 'utopian' vision. If previous utopias had been models of the existing society brought to a pitch of perfection which it could never reach, of a religiously unworldly existence, of an unrealisable dream, More's was able to posit, however tentatively, utopia as a positive and radically different model, which might actually be brought about by human action. At the same time, the positive side of utopia, which saw a bright future opening up, was accompanied by its opposite, anti-utopia or dystopia, which emphasised the negative potential inherent in society's new-found capacity for change.

But the change taking place in More's time was not 'change' in the abstract, or a generalised transition from the 'pre-modern' world to 'modernity': it was the specific advent of the capitalist mode of production and of a class of capitalists, traditionally though problematically referred to as the bourgeoisie. It is the virtue of the English Marxist critic A. L. Morton's account of the English utopian tradition that derived from More, that it sets utopia firmly within this social context. ${ }^{522}$

'It is impossible,' he tells us, 'to get very far with the writing of a history of utopianism without realising that what one is really writing about is the history of a special aspect of the bourgeois revolution: the rise and decline of Utopia cannot be separated from the rise and decline of the bourgeoisie as a progressive class, since at every stage it reflects the hopes, beliefs and fears of the most enlightened members of that class. ${ }^{523}$ The manner of Morton's insistence on the 'bourgeois' nature of utopia, redolent of vulgar-Marxist 'reflection theory', is at times irritating: he wrote, we remember at these points, as an orthodox Communist during Stalin's lifetime, and the weakest part of his argument is the assumption that 'utopia', along with the bourgeoisie, has been finally superseded by the creation of the Workers'

522 The English Utopia (London: Lawrence \& Wishart, 1952).

523 'Utopia as a Reflection of Social Ideas', Marxism Today, November 1962, 339-40. 
State. ${ }^{52}$ But the basic emphasis on connecting the literary and cultural phenomenon to particular social and class formations is crucial, and certain other features of his analysis are deeply suggestive. To mention two, there is his notion of a dialectic within the utopian mode, illustrated by the twin examples of Defoe and Swift: the positive, 'Whiggish' utopianism of the rising bourgeoisie, and the pessimistic anti-utopianism of Tory humanism. ${ }^{525}$ And there is the tendency, by the late nineteenth century, for anti-utopia or dystopia to win out, increasingly, over utopian optimism - intimately related to an actual social history which Morton thinks of, perhaps too single-mindedly, as the decline of the bourgeoisie as a progressive force, but which is no less real for that. I intend to carry some of these features across into the examination of 'utopia' in the nineteenth-century Arab world.

For it is in fact possible to see 'utopias', in the modern, post-More sense, as spreading across the globe largely in step with the spread of the power of capitalism, of the 'modern' militaryfiscal nation-state, and of the bourgeoisie. I can offer here only a cursory account of the phenomenon; but it is at least suggestive that More's Utopia arose in the country, England, where capitalism is seen by many as having its origin; and that it soon spread to those Western European and North American lands that were most closely bound into the original capitalist nexus. And from the eighteenth through to the early twentieth century, we see both literary utopias and, more loosely, 'utopian' thinking, multiplying across the globe, as the state-capital-class configuration itself advanced and multiplied. Utopias tend to multiply, as Morton suggests, in proportion to actual social change within the society concerned. In the

524 We may contrast the view of E. P. Thompson (building on arguments of Miguel Abensour) that socialism stands in continual need of the utopian 'education of desire': 'Romanticism, Moralism and Utopianism: The Case of William Morris', New Left Review 99 (1976): 83-111; or Raymond Williams's reconsideration of utopia: 'Utopia and Science Fiction'. For the flourishing of a utopian genre within the Actually Existing Utopia itself, see Darko Suvin, Other Worlds, Other Seas : Science-Fiction Stories from Socialist Countries (New York: Random House, 1970); idem, Russian Science Fiction, 1956-1974: A Bibliography: Original Books, Translated Books, and an Annotated Checklist of Criticism, with an Appendix on Criticism of Russian SF before 1956 (Elizabethtown, NY: Dragon Press, 1976).

525 The English Utopia, 86-110. 
eighteenth century, with the reforms of Peter and Catherine of Russia, we see utopian 'fragments' in Russian literature; ${ }^{526}$ in the mid-nineteenth century, after the upheavals of independence and revolution and intensified capitalist penetration, we see a Latin American utopian (as well as dystopian) literature ${ }^{527}$ in the late nineteenth century, with the Tokugawa and Meiji 'modernisation', we see a Japanese 'utopian' literature emerging. ${ }^{528}$ One index of this spread might be the global spread of translations of classic European works of the bourgeois Enlightenment, with a strong utopian component: Les aventures de Télémaque, Robinson Crusoe, Paul et Virginie.

Of course, we should not assume a mechanical relationship between the politico-economic history on the one hand and the literary and cultural history. ${ }^{529}$ In each of these specific cases, the rise of a local 'utopian' form took place in a particular local context which cannot be simply explained by reference to a general trend. But it is helpful from the outset to get beyond the narrowness of the Arab literary tradition by placing it within this global trend. With this in mind, we can define the phenomenon under investigation here as the Arab utopia in the post-More rather than the pre-More sense: utopia as a response to actual social change, brought about largely under the influence of capitalism. This Arab utopia includes both actual literary utopias like More's (of optimistic and pessimistic, 'anti-utopian' or dystopian kinds), and some of the more disparate phenomena often grouped around these, as 'utopianism': reflections on social change, political, economic or cultural programmes, and so on.

526 Jean Breuillard, 'Fragments d'Utopies Dans La Littérature Russe Du XVIIIe Siècle: Levšin et Xeraskov', Revue Des études Slaves 56, no. 1 (1984): 17-31.

527 Beatriz De Alba-Koch, 'The Dialogics of Utopia, Dystopia and Arcadia: Political Struggle and Utopian Novels in Nineteenth-Century Mexico', Utopian Studies, 1997, 19-30; Joseph L. Love, 'Utopianism in Latin American Cultures', in Aware of Utopia (Conference on Utopia in Comparative Focus), ed. David W. Plath (Urbana: University of Illinois Press, 1971), 118-9.

528 Moichi, 'Japanese Utopian Literature'; Aldridge, 'Utopianism in World Literature'; Nuita, 'Traditional Utopias in Japan and the West'.

529 For an account and critique of mechanical theories of culture as simple 'reflection', see Williams, Marxism and Literature, Ch. 4: 'From reflection to mediation'. 
The pre-eminent example of an original Arabic literary utopia, in the period under discussion - the mid-nineteenth century - is Fransīs Marrāsh's Ghābat al-Haqq (1865). This, along with its immediate contexts, will accordingly be the main focus of this chapter. But around Marrāsh's work I will group others: the more disparate 'utopianism' to be found in Nahda writing of the period; his antecedents both in European and in earlier Arabic writing; and the later development of the Arabic utopia of capitalist modernity.

\section{Utopian Thinking in the Nahda}

Both Syria and Egypt were being transformed, in the 1860s perhaps more visibly than ever before, by the impact of capitalism, the rise of the reforming state, the growth of the "new social classes'. It is obvious that the sense of a 'New Age' dawning, which we have seen in Khalīl al-Khūrī, was a response to these actual changes. Perhaps the most direct form of this response can be seen in the presence of new technologies in the Arabic press and literature of the period: in a newspaper like Hadīqat al-Akhbār we regularly see steamships (in the form of shipping listings), the telegraph (in the form of 'telegram' news items), and descriptions of various 'new inventions'. Elizabeth Holt has given an excellent description of the response to one technology, the hot air balloon, in the press of the early $1870 \mathrm{~s}$; as she notes, 'scientific advances $[\ldots]$ become imbued with a tinge of the fantastic'. ${ }^{530}$ Not just hot air balloons but a range of technologies and scientific discoveries were seen in this way, as the many poems and poetical expressions on steam-engines and the like show. ${ }^{531}$ Such discoveries may have

530 Holt, 'Narrative and the Reading Public in 1870s Beirut', 69; see also the many examples in Holt, 'Serialization and Silk'.

531 For Tahtawi's steam-engine poem, Manāhij al-albāb, 126; see also the other allusions to railways etc. mentioned in Albert Hourani, Arabic Thought in the Liberal Age, 1798-1939 (London: Oxford University Press, 1962), 81; Marrāsh also has poems on technical inventions in Mir'ät al-ahwāl. The steam train could still serve, in 1908, as a symbol of innovation and progress: see Sasson Somekh's analysis of the 
contributed to the 'disenchantment' of the world, but they often appeared, at first sight, as forms of enchantment. ${ }^{532}$

Most of these radically new elements in technology as in wider social relations had originated in Europe; and we may see a relatively direct apprehension of the changes in the world in the well-known travel accounts, the rihla literature. Europe could indeed appear as a kind of utopia (or perhaps more strictly 'heterotopia'); Marrāsh himself was to give almost a textbook example of the genre in his 1867 Rihlat Bāriss. ${ }^{533}$ But we have to remember the extent to which, in even the most adulatory description, the elements selected for emulation were, precisely, selected, by Arab writers whose intentions and priorities were not - could not be - the same as those of Europeans. We have already seen Bustān̄̄ss insistence on the dangers of merely copying the externals of European civilisation. The same theme recurs in an article of Khalīl al-Khūrī's 'On the English Nation': everyone, he writes, knows of England's greatness and power,

But it is rare that the majority care to seek for the reasons of this greatness and [imperial] extension, which have no known equal in history. They look at England as one looks at a fine mechanism, one of the inventions of human industry: they are amazed at its strange constructions, while ignorant of the secrets of its constitution and the wisdom of the principal components joined together by their association one to another $[\ldots . .]^{534}$

Iraqi poet al-Rușāfî’s 'Fī al-qitār' (1908): 'The Neo-Classical Arabic Poets', in Modern Arabic Literature, ed. M. M. Badawi, Cambridge History of Arabic Literature (Cambridge: Cambridge University Press, 1993), 72-4.

532 'Disenchantment' was Max Weber's term: Sung Ho Kim, 'Max Weber', in The Stanford Encyclopedia of Philosophy, ed. Edward N. Zalta, Fall 2012, http://plato.stanford.edu/archives/fall2012/entries/weber/; one interesting reappraisal in a modern Lebanese context is Lara Deeb, An Enchanted Modern: Gender and Public Piety in Shi'i Lebanon (Princeton University Press, 2006). Modern technologies were not only seen as 'enchanted' in the Arab world, of course; they had been new in Europe not long since: Ralph Waldo Emerson recorded in his Journals for 1842: 'Milnes brought Carlyle to the railway, and showed him the departing train. Carlyle looked at it and then said, "These are our poems, Milnes."' Journals of Ralph Waldo Emerson, vol. VI: 1841-44 (Boston and New York: Houghton Mifflin, 1911), 251. On the grand railway schemes of this period (and an example of 'wonder' from Bengali literature and film), see also the remarks in Hobsbawm, The Age of Capital, 72-4; and compare Williams's analysis of the role of the railway in Dickens's Dombey and Son: The English Novel from Dickens to Lawrence, 42-44.

533 See Stephan, 'Aspekte Des Tamaddun', 106-110, '3.2.1. Tamaddun als Utopie in Europa - Riḥlat Bārīs'. 534

غير انه قلما يلتفت الاكثرون الى البحث عن اسباب هذه العظمة وهذا الامتداد الغير المعروف لهما مثل فى التاريخ فانهم ينظرون

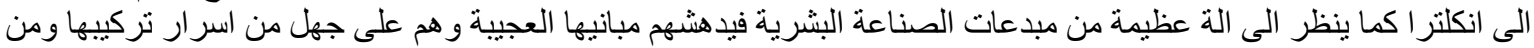


He goes on to describe the two unique characteristics of the English: their great 'patriotism' (hubb al-wațan), to the point of chauvinistic dislike for anything foreign; and their lack of susceptibility to the emotions. This means that they act always according to reason, rather than emotion; the Englishman is able to apply himself to a given task without boredom, for a great length of time; hence his capacity for skilled specialisation. He concludes his machine analogy:

the great mechanism that is made up of a number of parts whose movements are various cannot complete its work unless each part is restricted to its particular movement. $^{535}$

It is in this context, interestingly, that we find what must be one of the first references in Arabic to those thinkers Marx and Engels were to dub the 'utopian socialists': Fourier, SaintSimon and Robert Owen. This is instructive, as it reminds us which kinds of 'utopian' thinking were not acceptable to Nahda writers of Khūrī's stamp. The English 'patriotism' extends to the poor, Khūrī argues, and this, along with their unsusceptibility to emotions, makes them immune to 'revolutions' or 'movements' (harakät - a term also used for peasant risings in Lebanon, and sometimes used to translate 'revolution' ${ }^{536}$ ) against the rich and nobles.

Thus the works of the English, especially in great matters, [the first instalment of Khūrî's article concludes] are free from the defect of those emotional influences which often overthrow the guidance of reason and lead the nation astray into the wilderness of impossible hopes. The opinions and dreams, exceeding the world of truth and reality, that proceeded from the first French Republic, bear witness to the truth of this. ${ }^{537}$

535

$$
\text { حكمة الاو ايل المجتمعة بانضمام بعضهم الى بعض [...] }
$$

الالة العظيمة المجتمعة من عدة اجز ا مختلفة الحركات لا يمكن ان يتم عملها اتا اذا اقتصر كل جز منها على حركتها الخصوصية

536 E.g. in J. H. Merle d'Aubigné, Tārīkh al-iṣlāh fì al-qarn al-sādis 'ashar (History of the Reformation in the Sixteenth Century), trans. Cornelius V. A. Van Dyck (Beirut: American Press, 1878).

537 'F̄̄ al-umma al-inklīziyya', Hadīqat al-Akhbār 66, 9 April 1859.

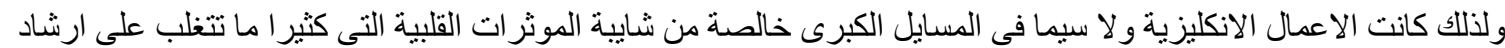

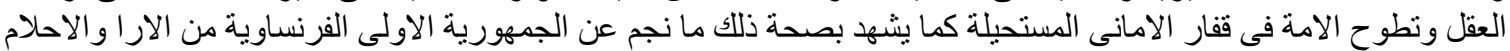
الثاطة عن عالم الحقيقة و الوجود الإن 
In the second instalment, he continues: the English, restricting their views to 'possible things' (al-ashyā' al-mumkina) 'whose benefits are unanimously agreed' (wa-allatī lā khilāf

\section{fì fāyidatihim),}

cannot be seduced by the magic of the new opinions and the philosophical systems which would be able (as their supporters claim) to remove evil from this world, so that it would become a kind of heavenly paradise, overflowing with all kinds of delights, without the admixture of the least suspicion of the natural evils inseparable from our human essence, as has claimed Fourier (1) the famous Frenchman, and Saint-Simon $(2)^{538}$

Despite the efforts of Fourier and Saint-Simon to spread their ideas, they fell on deaf ears in

England.

And when the Teacher Owen the Englishman wished to advocate the views of Fourier and his like and wrote a discourse on it that tried to clarify to the people of his country the school of sharing (madhhab al-mushāraka: communism or socialism) in a way suitable to their national tastes, most of them attributed his speech to the action of melancholia, known among them by the name of spleen, and paid no heed to him or his teachings. ${ }^{539}$

The rational English were not swept away by the seductions of the doctrine of the

perfectibility of man. In footnotes, Khūrī explains:

Note: (1) Fourier is one of the writers of this century who claimed that laws and in general all means of inhibition and discipline are useless in improving the conditions of man, indeed that they, on the contrary, are the reason for the existence of evil in this world. And he thought that it was necessary to leave the wilfulness of natural desires in complete freedom, because there is as he claims in their totality that which preserves them from defects and from being directed to evil purposes. He wrote on that a very abstruse book in which he included the fetters of the desires, and listed their kinds and the ways of educating them. This school of his includes necessarily the school of absolute communism (al-mushāraka al-mutlaqa).

(2) Saint-Simon is one of the famous men of this age, head of the heresy of the SaintSimonians, who propound absolute communism even in the family relation. ${ }^{540}$

538 Hadīqat al-Akhbār 68, 23 April 1859.

لا يمكن ان توخذ بسحر الار ا الجديدة والنظامات الفلسفية التى ينبغى ان ترفع بها على ما بز عم اولياو ها كل شر من هذا العالم حتى التى

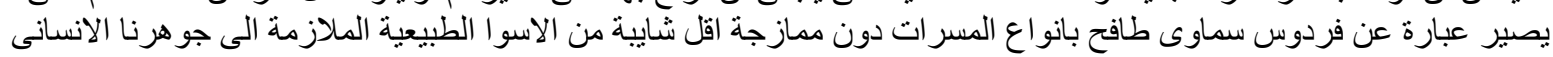

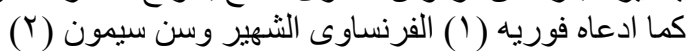

539

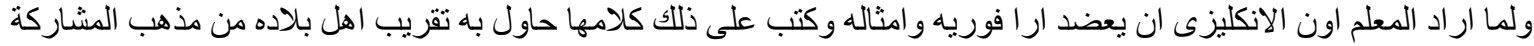

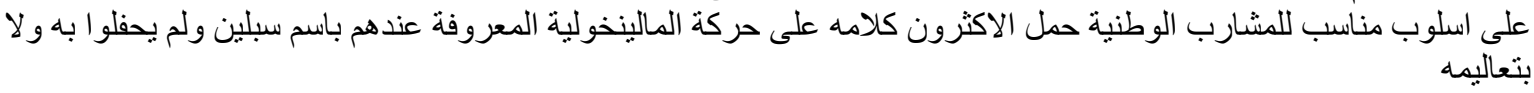
540

حاثية ( ) فوريه هو رجل من كتبة هذا الجيل زعم ان الرايع وفى الجملة جميع الوسايط الرداعة والتاديبية لا فايدة لها فى ترقية 
Such vistas of human perfectibility were not for Khūrī: he preferred the capitalist English, working together rationally as a well-functioning, revolution-free machine.

But modern, civilised Europe itself was not the only kind of other world available to literate Arabs. As I have argued above (Chapter 3), the expansion of geographical consciousness in this period took in much of the (European-dominated) globe, beyond Europe itself. Other 'heterotopias' - examples of societies where things were done differently, to be admired or despised - could be found in descriptions of China or India (later Japan would be much in vogue as an example of a non-European nation that had 'progressed' ${ }^{541}$ ). The geographical mobility we see enacted in those quasi-utopian European works which were translated in this period - Télémaque, Robinson Crusoe, Paul et Virginie - also bears an obvious relation to the expansion of geographical knowledge.

There was then the expansion of historical knowledge, which I have mentioned only briefly: those other social possibilities disclosed by the Ancient world, and by the medieval and early-modern stages of European history, in addition to the contemporary world. As for a vocabulary and set of concepts for dealing with different kinds of society, including ideal or potential ones, most obviously there was the discourse of 'civilisation', which we have seen elaborated in Bustānī and others. And as we have seen, this was itself a dialogue between European-derived histories and ways of thinking about history, and Arabic and Ottoman ones - in particular the thought of Ibn Khaldūn. There were also, of course, the inheritances of

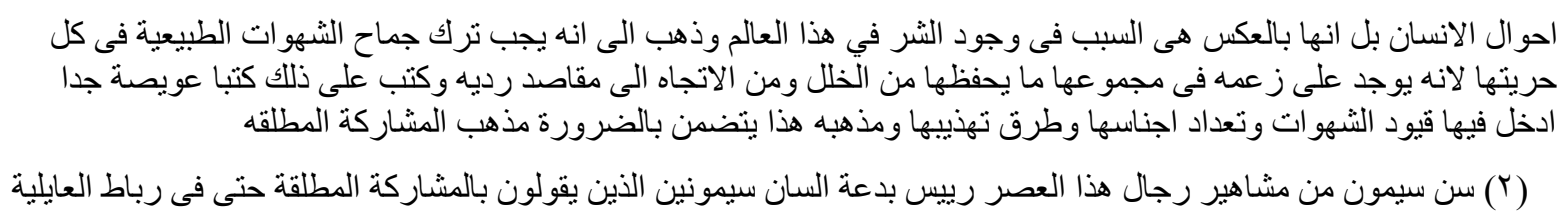

541 See, for instance, Eiji Nagasawa, Modern Egypt Through Japanese Eyes: A Study on Intellectual and Socio-Economic Aspects of Egyptian Nationalism (Cairo: Merit, 2009); Renée Worringer, Ottomans Imagining Japan: East, Middle East, and Non-Western Modernity at the Turn of the Twentieth Century (Basingstoke: Palgrave Macmillan, 2014). 
dream- and vision-literature, of images of Virtuous Cities, from the Arabic heritage: Kalīla wa-Dimna, al-Fārābī, Hayy ibn Yaqzānn. It is difficult to say exactly what of this heritage was available to Arab writers of the nineteenth century: Kalīla wa-Dimna was well-known (it was printed at Bulaq in 1834 and 1869, and at Beirut twice in the 1880s); and Hayy ibn Yaqzān was certainly known in Europe; but al-Ma'arrī's Risālat al-ghufrān does not seem to have been 'rediscovered' until the early twentieth century. Certainly some of the resemblances between these works and the new, European-derived 'mirrors for princes', were clear enough: Muhammad 'Abduh listed Télémaque alongside Kalīla wa-Dimna and the Marzbān-nāma as good and improving literature, in $1881 .{ }^{542}$ Télémaque offered a great range of different possible societies to choose between - from the 'primitive' society of Bétique, with no laws and no money, to the electoral monarchy of Crete and the rationally reformed government of Salente. Robinson Crusoe also offered, as well as a parable of the origins of an economy and the division of labour, a desert-island and 'primitivist' way of living; Paul et Virginie provided a more romanticised version of the same.

All of these examples - from other places, other times, imagined societies - could then be juxtaposed with, or compared to, the here and now of Syria or Egypt, Beirut, Cairo or Aleppo. Indeed, there is a powerful strand of emphasis on the natural advantages and future prospects of Syria, or Beirut, or Egypt, which can at times verge on the utopian. This is complicated by the fact that these often appear also - perhaps originally - in European writings, and can be bound up with imperialist ambitions (the advantages of the country if under European rule) as well as a dismissal of the present inhabitants of the land in favour of past civilisations which flourished so much more than later ages of decline. We have already seen an example of this in Malte-Brun: but his original was Volney, whose reflections in Les $49-50$. 
Ruines begin with his visit to Palmyra in Syria:

Here, said I, once flourished an opulent city; here was the seat of a powerful empire. Yes! these places now so wild and desolate, were once animated by a living multitude; a busy crowd thronged in these streets, now so solitary. [...] This Syria, said I, now so depopulated, then contained a hundred flourishing cities, and abounded with towns, villages, and hamlets. In all parts were seen cultivated fields, frequented roads, and crowded habitations. Ah! whither have flown those ages of life and abundance? - whither vanished those brilliant creations of human industry? Where are those ramparts of Nineveh, those walls of Babylon, those palaces of Persepolis, those temples of Balbec and of Jerusalem? Where are those fleets of Tyre, those dock-yards of Arad, those work-shops of Sidon, and that multitude of sailors, of pilots, of merchants, and of soldiers? ${ }^{543}$

We have already seen evocations of similar scenes in Khūrī’s Kharābāt Sūriyyā and elsewhere; Marrāsh's Ghābat al-Haqq contains some more. Among the first to emphasise the potential force in the world of a unified Arab race were Protestant missionaries, seeing in it a possible instrument for the spreading of the Gospel: 'the great Arab race', they wrote in 1844 , is

everywhere substantially the same $[\ldots]$ in origin, the same in language, and literature; [...] in external manners, habits and customs; and in the internal springs of action. [...] Nations and kingdoms, numerous and powerful, have risen, and flourished, and fallen, and disappeared, but they continue. [...] The Arab race cannot die. [...] Again, this people always has exerted, and probably always will exert, a powerful influence on a large portion of the human race. There are social, and civil, and intellectual, and moral elements in their character, which fit them for it; and their position in the centre and heart of the world ensure and perpetuate it They occupy the birth-place and the cradle of mankind. ${ }^{544}$

Antonius Ameuney was to use similar arguments to drum up support among British readers

for a new Arabic newspaper, in $1860 .^{545}$ The whole question of the relationship between

these European tropes and the ideas that were gradually taking form in the Arab countries

543 The Ruins, Or, Meditation on the Revolutions of Empires (Paris Translation) (New York: Twentieth Century, 1890), Ch. II: 'The Reverie'. Either the Ruines or Volney's Travels in Egypt and Syria (with similar reflections) was probably translated into Arabic at Damietta early in the nineteenth century: see Hill, 'The First Arabic Translations of Enlightenment Literature'; Philipp, The Syrians in Egypt, 1725$1975,69$.

544 'Syria Mission; Value of the Field', Annual Report of the American Board of Commissoners for Foreign Missions 1844 (1844): 122-27. This report was drawn up by the Syria Mission in Beirut, in justification of their own efforts, during the visit of Rufus Anderson, Secretary of the ABCFM. Cf. 'Reports of committees', Annual Report of the ABCFM, 1860, 16-17, celebrating having given 'a version of the New Testament to a race so wide-spread and influential as the Arab'.

545 'An Appeal on Behalf of 80,000 of the Human Family', in Ameuney, Notes from the Life of a Syrian, 6578. 
themselves as 'awakening' versus 'decadence' (nahḍa and inhițāț) certainly needs further investigation. ${ }^{546}$ But it would be wrong to assume that all such ideas, even where they can be traced to some European origins, necessarily remained captive to these origins (and hence part of a 'European' or 'imperialist' way of seeing the world). We have already seen, in Ṭahțāwì's careful rewriting of Malte-Brun's speculations on the potential of Syria, one way in which European designs could be taken over and adapted to rather different ends. To take another example, Jens Hanssen has drawn attention to writings in praise of Beirut through the nineteenth century, with odes referring to the 'blessed geography', 'the splendid views', and 'the rich history' of the city. From the early 1870s, he argues, 'al-Jinān began to ascribe to Beirut a particular geographical role and systematically mapped out the city's future.' Salīm al-Bustānī’s article 'Markazunā' of 1872 refers to Beirut as a 'gate' (bāb) between trade and agriculture, the sea and the hinterland, West and East. The theme is continued in Salīm's writing in the 1880s: in one place, Beirut's natural situation is seen as making it into a 'little earthly paradise' (firdaws arḍ̄ șaghīr). ${ }^{547}$ This may be seen as an already common pride in the city, its beauties and pleasures, becoming inscribed into a historical and geographical consciousness: an awareness of natural advantages and prospects for progress. And once again, it is local, Beiruti interests that are foregrounded here, rather than European ones.

It is in this context, then, of the range of ways of thinking about possible other forms of society - past and future, here and elsewhere, real and imagined - that we must situate that specific form of 'utopian' thinking that we see in Khūrī and again in Marrāsh - the sense of a 'new age' dawning - which may be seen as a register of a qualitatively new kind of

546 The current state of research is represented by, for instance, David Fieni, 'French Decadence, Arab Awakenings: Figures of Decay in the Arab Nahda', Boundary 2 39, no. 2 (2012): 143-60; and a rather unsatisfactory article by Jeffrey Sacks, 'Futures of Literature: Inhitat, Adab, Naqd', Diacritics 37, no. 4 (2007): 32-55.

547 Hanssen, Fin de Siècle Beirut, 226-30. Salīm al-Bustān̄̄, 'Markazunā', al-Jinān, 3 (1872) 145; and 'Madīnat Bayrūt wa-iḥtiyājātuhā,' al-Jinān, 15: 16 (1884), 381. 
consciousness of change. Yet even this notion already had a prehistory. It may be seen as being prefigured in the proclamation of Mehmed Ali of Egypt (and the Ottoman Sultans Selim III and Mahmud II before him) as 'renovator' (mujaddid), so often found in the eulogies that issued from the Bulaq printing press. This was not inappropriate to the scale of actual change entailed in these rulers' reforms, embodied in their personal image: it persists in the comparisons of Mehmed Ali with the heroic figures of Alexander and Napoleon.

And here, as with technology, we have to see the element of wonder, of the fantastic, in even what looks like a mundane, Whiggish record of 'progress'. The early Protestant missionaries to Syria and Palestine were imbued with messianism, that sense of the 'flying of time' described by Ussama Makdisi. ${ }^{548}$ This sense was transmitted, perhaps, to some of their Arab converts: Mīkhā'îl Mishaqa wrote that he was converted by his reading of Alexander Keith's Evidence of the Truth of Christianity Revealed in Prophecy, an eschatological work showing the fulfilment of the prophecies of the Bible in history. ${ }^{549}$ The parallel to those missionaries and others who saw the upheavals in the world - revolution, war, undermining of the Catholic Church and Ottoman Empire - as preparations for the Apocalypse, is close. ${ }^{550}$ Makdisi has argued that this messianic urgency mellowed, through the nineteenth century, into a less cataclysmic sense of 'secular time', but I think it is possible to see many ways in which the earlier urgency, and something of the millennial expectation, were not supplanted by but re-attached to a secular-enlightenment project. We can see one particularly interesting point of transfusion, from an Evangelical to an Enlightenment project, can perhaps be seen in the first volume of proceedings of the Syrian Scientific Society, edited by Bustānī. Here we find the Armenian-Arab Protestant doctor, John Wortabet, writing on 'The Measure of the

548 Makdisi, Artillery of Heaven.

549 Thackston, Murder, Mayhem, Pillage, and Plunder: The History of the Lebanon in the 18th and 19th

Centuries by Mikhayil Mishaqa (1800-1873), 235-6.

550 Compare the eschatological imaginings of Rev. Wolf, in Hill, 'Early Arabic Translations'. 
Progress of Knowledge in Syria at the present time, and its causes'. His paper concludes (in

Edward Salisbury's contemporary translation):

The former times have passed away, their people are no more, their darkness is gone [...]; and another era is opening for Syria - an era of light. [...] Since the dawn has at length appeared, let us rise and bestir ourselves. Already, have many opportunities been lost; and there is much for us to do before we reach the goal. Would that I had a trumpet-voice, - it should arouse this whole country. I would sound a warning in the ears of the slumbering, that the dawn has come, and we must be up and doing. ${ }^{551}$

This is the language of the pulpit, but calling the audience to 'knowledge' rather than

religion. Six years later, Khalīl al-Khūrī issued his call, which we have seen:

So it is up to you, people of the country, young men of the homeland: your minds must be stirred by cultural honour, and your bodies shaken by patriotic ardour, so that you storm forth to acquire knowledge and science $[\ldots . .]^{552}$

And in 1860, Bustānī was to address his countrymen with the 'trumpet-voice' of Nafir

Süriyyā. Soon after, John Wortabet would be teaching, in Aleppo, the apprentice doctor

Fransīs Marrāsh, whose Ghābat al-Haqq, another five years later, would culminate in the words:

I heard a voice resounding through the clouds, calling: 'Bear tidings, bear tidings, o ancient desert of Aramea; and rejoice and be glad, o Shahbā' of Syria: behold kingly Providence coming to you!' [...] I saw [the horizon] transformed to a sea of shining light, which began to sparkle like the morning sun in a cloudless sky [....] ${ }^{553}$

551 Edward E. Salisbury, 'II. Syrian Society of Arts and Sciences', Journal of the American Oriental Society 3 (1853): 486; Yūḥannā Wartabīt, 'Miqdār Ziyādat al- 'ilm fī Suriyyā fī Hādhā al-J̄̄l', in A 'māl al-Jam 'iyya al-Sūriyya li-Iktisāb al- 'ulūm wa-l-Funūn, ed. Buṭus al-Bustān̄̄, vol. 1 (Beirut: American Press, 1852), 10-13.

قد مضى ذلك الجيل واهله وظلامه مع عناصره الاربعة وبدأ تاريخُ اخر لسوريا ـ تاريخ النور. نعم انهُ لبس الا سحرٌ بعد و انما لا

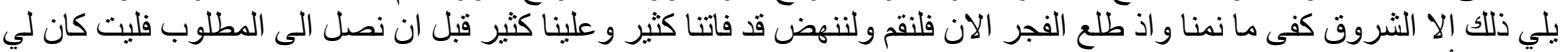

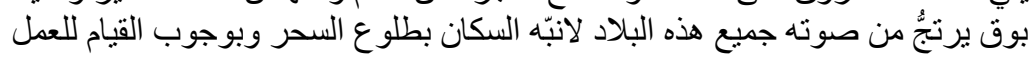

552

فعليكم الان يا اهالى البلاد ويا فتيان الوطن ان تلعب بروسكم النخوة الادبية وتهز اعطافكم الحمية الوطنية لتهجموا على اكتساب المعارف و الفنون [.....

553 Ghābat al-Haqq (Aleppo, 1865), 164-5; Ghābat al-Haqq (Beirut, 1881), 134.

سمعت صوتأ يدوي من خلال الغمام وينادى قائلا * ابشري ابشري يا برية ار ام القديمة وافرحى وابتهجى يا شهباء سوريا فها العناية

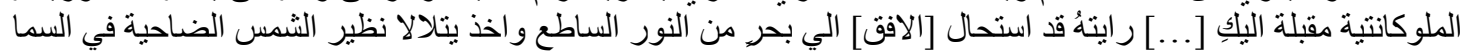

الصاحية . [...] 


\section{In the Forest of Justice}

In 1865, when Ghäbat al-Haqq was first printed in Aleppo, Marrāsh was 29 years old, and coming to the end of his apprenticeship with Dr John Wortabet. ${ }^{554}$ Soon afterwards, he would travel to Paris to continue his medical studies, producing an account of the experience, Riḥlat Bārīs, in 1867. He had previously accompanied his father, Fatḥallāh Marrāsh, a middling Aleppine merchant with consular connections, of a Greek Catholic family, to Paris and Beirut. But 1865 saw Fransīs within a tightly-knit and specifically Aleppine circle, which qualifies for description as a separate cultural 'formation', in Raymond Williams's sense, within the wider Nahda movement. ${ }^{555}$ This was based around a few wealthy, cultured, Christian families in the Judayda quarter of Aleppo such as the Marrāshes and Dallāls, who interacted regularly at majālis or salons. ${ }^{556}$

He had already published three works: Risalat al-mir'āt al-ṣafiyya fi mabādi' al-tabī'a (Treatise of the Clear Mirror on the Principles of Nature), a compilation on the natural sciences, which 'Alī al-Shar' suggests was probably made for pedagogical purposes $;{ }^{557}$ Dalīl al-ḥurriyya al-insāniyya (Guide to Human Liberty, 1861), a call to reform specifically among the Christians of Aleppo; and Khuṭba fi ta ziyat al-makrūb wa-rāhat al-mat 'üb (Sermon on the Consolation of the Sorrowful and the Ease of the Weary). Ghäbat al-Haqq

\footnotetext{
554 Wortabet was identified as Marrāsh's mentor in an unpublished study by Majīd Șawāyā, cited by both 'Alī al-Shar', Fransīs Fathallāh Marrāsh wa-Dawruhu fì al-Nahḍa al-Fikriyya wa-l-Adabiyya al-hadītha (Fransīs Fathallāh Marrāsh and His Role in the Modern Intellectual and Literary Awakening) (Irbad, Jordan: Dar al-Kindi, 2008), 15; and Karam al-Hulw, al-Fikr al-Lībrālì 'inda Fransīs al-Marrāsh : Binyatuhu wa-Ușūluhu wa-Mawqi 'uhu fì al-Fikr al-'Arabì al-hadīth (The Liberal Thought of Fransīs alMarrāsh: Its Structure, Origins, and Place in Modern Arab Thought) (Beirut: Markaz Dirāsāt al-Waḥda al'Arabīya, 2006), 58 (see note 35 for Șawāyā's evidence).

555 Williams, Marxism and Literature, 119; 'The Bloomsbury Fraction', in Raymond Williams, Culture and Materialism: Selected Essays (London: Verso, 2005).

556 See Bārūt, Harakat al-Tanwīr al- 'Arabī; al-Shar', Fransīs Fathallāh Marrāsh. Qusțākī al-Humșī, Udabā' Halab Dhuwū al-Athar fì al-Qarn al-Tāsi' 'ashar (Notable Literati of Aleppo in the Nineteenth Century) (Aleppo: Maronite Press, 1925) provides the testimony of a first-hand participant in this milieu; Haidar, 'Aleppo: The First Ground for Arab-European Cultural Encounters' is a helpful overview in English. 557 Fransīs Fathallāh Marrāsh, 51-2.
} 
appeared with no press imprint (though some have claimed it as a product of the Maronite

Press), but with two dedicatory odes: one to Îlyān Niqūlā Îlyān, who financed the printing, and the other to the then governor of Aleppo, the Ottoman reformer Ahmed Cevdet Pasha. Neither poem appeared in its later editions (at least in any I have seen): the omission of the poem to Cevdet aided the propagation of the notion that Marrāsh was a proto-Arab nationalist, irreconcilably opposed to the Ottoman rulers. ${ }^{558}$ As we shall see, his views of the Ottomans may have changed with time; but 1865 found him - like most of his Aleppine circle, in all probability - a believer in Ottoman reform for Aleppo and Syria under the benign rule of Sultan Abd al-Aziz. Indeed, the closeness of Aleppo and of the Christian Aleppine literati to Ottoman reformism may go some way towards explaining why this explicit 'mirror for princes', this overtly utopian blueprint for civilisation installed from above, appeared, in these years, from Aleppo rather than from Beirut or Cairo.

The 'Prologue' presents an unnamed narrator, who, wandering in 'the valleys of mental contemplation' (awdiyat al-ta 'ammulāt al- 'aqliyya), witnesses a 'strange scene' (mashhad 'ajīb): ${ }^{.59}$ first a procession of human civilisations, from the Egyptians to modern America, and then, as Chapter 1, 'The Dream' (al-Hulm), opens, the great forest of the title, in which a

558 The publication history of Ghäbat al-Haqq remains unclear in several points. The earliest attribution of the book to the Maronite Press that I have found is in the preface to a 1920s edition by 'Abd al-Masīh alAnțākī: n.d., Mațba 'at al- 'umrān, n.p. (preface dated Cairo, 1922), mentioned in Wielandt, 'Marrâsh Und Die Aufklärung', 117 n. 5, 124 n. 23 (for Anțākī, see al-Humșị, Udabā' Halab, 100ff.). Later scholars like Karam al-Hulw (al-Fikr al-Lìbrāli $\bar{\imath}$,272) attribute his three earlier works also to this press, but the history of printing in Aleppo in this period remains, as far as I know, rather obscure. The later editions I have come across were: (1) Beirut 1881 (which I cite here along with the 1865 edition); (2) Cairo: Mațba at Muhammad Efendi Farīd, 1298 (1880-1), including Mashhad al-Ahwāl; (3) the above-mentioned Anțākī edition; (4) London: Riyāọ al-Rayyis, 1989 (ed. Haydar Ḥājj Ismā' îl), also including Mashhad al-Ahwwāl; (5) Damascus: Dār al-Madā, 2001 (ed. Jābir 'Asfūr/Gaber Asfour). See Wielandt, 'Marrâsh Und Die Aufklärung', 124 n. 23, for some of these and references to other, perhaps apocryphal editions. Wielandt also believed the 1865 edition to be apocryphal. Al-Hulw, al-Fikr al-Lībrālī, 70-1 n. 27 also gives various conflicting accounts of the history of the printing of the book.

559 Ghābat al-Haqq ([Aleppo]: s.n., 1865), 2; (Beirut: Mațba at al-Qiddīs Jāwirjiyūs li-l-Rūm al-Urthūdhuks, 1881), 2. Hereafter I will cite Ghäbat al-Haqq (omitting the title) from the 1865 edition, but also reference, after a semicolon, the more easily obtainable Beirut edition of 1881. The latter and the Cairo 1880/1881 edition, on one of which all later editions seem to be based, were 'corrected' from the original: not only for punctuation and orthography but also, frequently, for grammar and style. The dedicatory poems were also cut. 
set of figures - the King Freedom, the Minister Love-Peace and the Captain of the Army of Civilisation - are discussing their battle against the Kingdom of Slavery. The news of the latter's defeat arrives; and they summon another figure, the Philosopher (al-Faylasüf) from the City of Light (Madinat al-nūr) to advise them on what to do with the prisoners. In Chapter 2, 'Reveries' (or perhaps 'Anxieties': al-Hawājis), he arrives, and being asked whether it is possible to get rid of the Realm of Slavery, a discussion ensues over lawed determinism and free will in nature. The Philosopher concludes that there is no natural freedom, but 'moral' or 'cultural' freedom (al-hurriyya adabiyyan) $)^{560}$ is possible, by following 'the laws of the state of civilisation and salvation' (ahkām dawlat al-tamaddun wa-l-ṣalāh $).{ }^{561}$

In Chapter 3, 'The Kingdom of the Spirit' (Mamlakat al-rūh), the characters discuss this other realm, which lies at the borders of the Kingdom of Civilisation. Against the suspicious King, the Philosopher argues that there is no opposition between civilisation and religion: religion is in fact the basis of civilisation. In Chapter 4, 'Statecraft and the kingdom' (alSiyāsa wa-l-mamlaka), the discussion turns to human and political affairs, the Philosopher offering a speculative narrative of the origins of governance, from the family to the tribe to kingship. The narrator (not the Philosopher) appears to describe a happy state, of just rule and obedient subjects, in a vision of his own, culminating in a patriotic 'War-song' (Harbiyya). ${ }^{562}$ In Chapter 5, 'Civilisation' (al-Tamaddun), the Philosopher lays out the 'laws of Civilisation', by way of which the conquered prisoners can be reformed, in five 'Pillars' (Da 'a 'im). These are: 1. 'The Refinement of Statecraft' (Tahdhīb al-siyāsa) - here he outlines the qualities of a good ruler; and of a good polity, including 'equality' (al-istiwa '),

$56041 ; 33$.

$56140 ; 32$.

$56260-65 ; 49-54$. 
largely before the law ${ }^{563}$, and the 'general/public good' (al-ṣālih al- 'āmm), which includes the encouragement of sciences, trade and industry. ${ }^{564} 2$. 'The Cultivation of Reason' (Tathqï $a l$ - 'aql) - here he gives a comprehensive educational programme in 'sciences and arts' (al'ulūm wa-l-funūn). ${ }^{565}$ 3. 'The Improvement of Customs and Morals', (Tahsīn al- 'awā' 'id wal-akhlāq), divided into 'private' (khāṣs ) and 'public' ( 'āmm) customs. ${ }^{566} 4$. 'The Health of the City' (Ṣaḥhat al-madīna), consisting of 'cleanliness' (al-nazāfa $)^{567}$ or hygiene, and urban planning reform. 5. 'Love' (al-Mahabba) - here the tone becomes lyrical: Love, as a law of Providence, ${ }^{568}$ governs both nature and human affairs; it is 'the goddess of society' (ilähat al-hay'a al-ijtimā 'iyya). ${ }^{569}$ Two cautionary poems are nonetheless given about the dangers of excessive passion. ${ }^{570}$

In Chapter 6, 'The Trial' (al-Muhākama), the Philosopher judges the enemy prisoners, who are allegorical vices such as the Captain of Ignorance $(Q \bar{a}$ ' $i d$ al-Jahl) or of Pride (alKibriy $\left.\bar{a}^{\prime}\right)$; they are confronted with their opposites, virtues such as Knowledge (al- ' $\mathrm{Ilm}$ ) or Humility (al-Ittid̄a $)$. In the trial of their leader, the King of Slavery, the Philosopher calls on Yāqūt, a negro, to present his story: he narrates his tale of being kidnapped into slavery in Sudan and then emancipated and educated. The Philosopher condemns the vices to be either extirpated entirely, or placed under the tutelage of their respective virtues. In the brief final section, 'Awakening' (al-Yaqza), the narrator returns, through thunder and confusion, to his own world, witnessing on the way voices and visions of 'the advent of good' (qudüm alkhayr) to Aleppo and Syria, ${ }^{571}$ under the rule of Sultan 'Abd al- 'Azīz. Finally, the horizon

$56374-5 ; 60-1$. $56477-9 ; 63-4$.

$56581 ; 65$.

56687 (misprinted as 78); 70.

567 98; 79.

568 102; 82.

$569105 ; 85$.

570 109-113; 88-92.

571 164; 133. 
becomes a sea of light, until he can no longer see; and passing again into the 'valleys of thought' (awdiyat al-hawäjis), ${ }^{572}$ he finds himself on his bed, 'beneath the sky of wakefulness' (tahta samā' al-yaqza). ${ }^{573}$

\section{Allegory, Dialogue and Narrative: the Framing of the Utopia}

This should give a sense of the remarkable scope of Marrāsh's work. Its centrepiece is, clearly, the utopian vision of 'civilisation' - announced at a point of transition from war (necessary to guarantee civilisation) to peace, comprising a great range of prescriptions for public and private virtues and vices. This, though mainly abstracted into allegorical figures, is in the finale relocalised into Syria and specifically Aleppo and its hinterland. Ghābat alHaqq is, I think, the first original 'utopia', in Morton's modern, post-Morean sense, to be written in Arabic. But while the 'mirror for princes' or political-civilisational utopia is central to the work, we should also attend to the way in which it is framed - first, literarily, within the formal convention of the dream and the 'valleys of thought' or imagination, and second, intellectually, within an overarching conception of the whole human and natural order.

Formally, Ghābat al-Haqq does not present an imagined 'other world' separated from our own by geography - like More's Utopia, many of the kingdoms visited by Telemachus and Mentor, or (though with an altered 'reality'-status) the geographies and anthropologies of Ṭahțāwî̀s translations or the riḥla tradition. Nor does it present an imagined different historical phase of our own world - like Morris's News From Nowhere, or the projections of 
a past golden age of Syria or Phoenicia. Rather, the world of Ghäbat al-Haqq - the 'Forest of Justice' - is an allegorised, abstracted version of Marrāsh's own world. The first shift the narrative performs, through the medium of the narrator's dream-awakening, is from the real world (Aleppo, Syria, in the 1860s) into this world: this shift is the formal equivalent of the voyage to Utopia, of the similar dream-awakening of Morris's narrator in a future London, or Bunyan's Pilgrim in a different kind of allegorised world.

At certain points (indicated in more detail below) the real Syria or Ottoman-Arab nineteenth century breaks through into the allegory: the realistic details of Yāqūt's story, the references to the American Civil War. But the overall framework is an abstract one, which perhaps owes a good deal to the similarly generalised terms of the older Arabic Mirrors for Princes. This formal device of estrangement - like others, including the transcultural or geographic ones of Les aventures de Télémaque, or Montesquieu's Lettres persanes - lends Ghābat al-Haqq the alibi of fictionality, permitting him to make recommendations or criticisms obliquely, as well rendering what follows striking and novel. The form it takes - as abstract allegory - also permits an appeal to general values and norms: we are offered, not simply the king of another country, but Freedom personified, reigning over Civilisation.

Within this allegorised world, however, there is a second shift, this time a historical one. For it is not captured in a steady, frozen state of perfection (or imperfection), as has been the tendency of the 'classic' utopian tradition: More or Morris, with their changeless, ahistorical worlds. Instead - although he does offer, in the Philosopher's prescriptions for Civilisation, a kind of static perfective blueprint - Marrāsh captures this allegorised world at a crucial point of transition: the war and conquest of Slavery/Barbarism by Civilisation. The transformation portrayed - the imposition of a regime of civilisation on the conquered - is evidently not 
wished for by the conquered themselves (who stubbornly and deceitfully resist it): if it is a revolution, it is a revolution from above. But it is not (to draw on distinctions made by Raymond Williams ${ }^{574}$ ) obviously the effect of a natural event external to humanity, like a comet or unexplained plague; nor of a purely technological innovation: Marrāsh, unlike the editors of Beiruti journals with their interest in 'new inventions', or the translators of Jules Verne in the $1870 \mathrm{~s},{ }^{575}$ seems rather indifferent to new technology, though deeply interested in new science, and the values of tamaddun are more obviously social and 'humanistic' than scientific or technological. ${ }^{576}$ And yet there remains a distinct ambiguity: can it finally be seen as a willed social and cultural transformation - though willed only by the Philosopher and court figures, not the conquered enemy - or is the agency displaced even from this limited group onto an unwilled, predetermined or Providential, historical destiny? For the onward march of civilisation is seen, in the opening and in many parts of the Philosopher's exposition, as virtually ineluctable: based on natural laws, it can hardly fail to rule the human world. ${ }^{577}$ There is also - admittedly a minor theme in Ghäbat al-Haqq, though much more insistently present in Rihlat Bāris - the suggestion that civilisation's highest form is to be found in the West. This would imply that the agency behind the transformation, if it has a human location, still does not find it in the Arab-Ottoman lands, Syria or Aleppo themselves, but in these other, Western lands - it is from the West that, in the final vision, the narrator sees the green tide spreading.

Yet in another way the advent of 'civilisation' is presented as not only a willed, but also a

574 See Williams, 'Utopia and Science Fiction', 196-199 for the categories of 'paradise or hell', 'externally altered world', 'willed transformation' and 'technological transformation'.

575 Stephen Sheehi, 'Arabic Literary-Scientific Journals: Precedence for Globalization and the Creation of Modernity', Comparative Studies of South Asia, Africa and the Middle East 25, no. 2 (2005): 438-48; Holt, 'Narrative and the Reading Public in 1870s Beirut'.

576 I draw on Williams's distinction between More and Bacon's New Atlantis: 'Utopia and Science Fiction', 199-200.

577 It might thus be compared with Bellamy's inevitable social transformation, in Looking Backward: Williams, 'Utopia and Science Fiction'; or again Jack London's, in The Iron Heel (though Shibli Shumayyil offers the closest Arabic analogue to these writers): 'Social Darwinism', in Williams, Culture and Materialism, 97. 
contested transformation - the contest that is seen as important being not that of the conquered enemy, whose opposition is delegitimised (they are after all by definition liars and traitors), but the argument between the rulers - allegorised rulers of Aleppo, Syria, the Ottoman Empire - the Minister, General, Queen, King, and Philosopher. All of them make different suggestions, and although the Philosopher's views are clearly presented as the correct ones, they have to be argued for, and at some points the argument is left apparently unresolved. In one way, it is the monologic discourse of the Philosopher which is dominant, and provides Marrāsh's 'message' in Ghābat al-Haqq - his understanding of nature and of human history, as well as his blueprint of 'civilisation', on all of which the planned historical transformation, of which we see a foundational stage enacted in the 'Trial' chapter, is based. And certainly the Philosopher's solution, as well as the authority of Civilisation in general, is legitimised by the natural and Providential understanding of history he offers. Nadhīr Ja far is I think right to see these monologues, and above all the chapter on Civilisation, as akin to newspaper articles written in the author's own voice. ${ }^{578}$ They cover a wide range of subjects, amounting, as I shall argue, to a 'cosmic' vision of both the natural and human worlds - this perhaps reveals a common Nahda ambition to encyclopedism, which Nadia Bou Ali has discussed in Bustānī and Shidyāq. ${ }^{579}$

But these article-like, monologic sections are held in tension with the dialogic arguments between the different rulers, which prevents us from seeing the Philosopher's solution as a merely predetermined outcome. In terms of the major action, the reader is left in uncertainty, at the start of the narrative as to whether Civilisation will win the war, and then through the six succeeding chapters, as to what solution will be adopted for the conquered enemy. (The

578 'Bunyat al-Lugha al-Sardiyya fī "Ghābat al-Haqq", in Fransīs Fathallāh Marrāsh Rā'idan Nahdawiyyan wa-Tanwīriyyan Baynanā (Fransīs Fathallāh Marrāsh: A Pioneer of Awakening and Enlightenment among Us), ed. Muhạmmad Jamāl Bārūt and İmān al-Șāliḥ (Beirut: Institut Français du Proche-Orient, forthcoming), 207-8.

579 'Hall of Mirrors', 198-206, 221-222. 
King of Freedom is indeed persuaded to return the prisoners to their country, and not to invade the Kingdom of the Spirit, but the Leader of the Army of Civilisation continues to doubt that the defeated enemy will become civilised in anything less than a thousand years.) And in terms of the intellectual arguments, there are unresolved disagreements or tensions between linear-progressive and Khaldūnian-cyclical conceptions of history, and between Providential and quasi-materialist conceptions of the physical world. As well as traces of the Aleppine salon debates in which Marrāsh's ideas had been formed, we can see in these features an unfinished, provisional quality - an openness reminiscent perhaps of Enlightenment dialogues like Diderot's - in tension with the monologic insistence on a particular, and abstract, vision of tamaddun. This may be seen as one formal aspect of the central ambiguity within Ghäbat al-Haqq, around agency and choice. Is 'civilisation' to be seen as inevitable - and the agency for it located ultimately either outside humanity entirely, in natural or God-given laws; or at least outside the people (even the rulers) of Syria and the Ottoman-Arab lands, in the civilisation-spreading West? Or can it be seen as something consciously chosen, by way of debate, among at least a few of the inhabitants of those lands, if only to be imposed on the others? The contradictory structure does not, I think, provide us with a final answer.

This contest between the Philosopher's monologue, in what appears for long sections indistinguishable from the author's own voice, and the directly presented dialogue of the characters, tends for most of the narrative to obscure that other level of narrative distancing implied by the presence of the original narrator, watching and overhearing these proceedings. Apart from the opening and the presentation of the 'Forest of Justice' itself, he intrudes only rarely, and most obviously in a scene-setting role at the opening of chapters (as with the ritualised scene, perhaps derived from Church services, of the appearance of the soldiers of 
Civilisation in the forest, at the start of Chapter 3). But embedded within the contest between monologue and dialogue there is - in addition to the Quranic, Biblical and poetic 'borrowings' which Ja far notes ${ }^{580}$ - a section of straightforward narrative, told by Yāqūt. He is called upon to speak and hence licensed by the Philosopher as part of the Trial proceedings - themselves a kind of stage-managed dramatic scene - amid the embodied vices and virtues, but clearly offers a tale, of enslavement and emancipation, more 'realistic' than 'allegorical' - a recognition, perhaps, of the persuasive value of personal testimony rather than abstract argument, on the crucial issue of slavery. His tale thus breaks back, with apparent inconsistency, into the 'real' world - Syria, Egypt, Anatolia - of the narrator's initial framing and the ending.

In this ending, the narrator re-emerges rather abruptly, and in a reversal of the original shift into the world of allegory - again accompanied by noise, movement and confusion - moves back to real 'Syria' and 'Aleppo'. We leave the world of wish-fulfilment, where the Philosopher's designs can come true (perhaps a little indulgently, in the Trial scene with its perfect combinations of good and evil?), and are left with the passionate and pious hope that this will be realised in actuality. There is a marked similarity of tone - a language at once visionary and urgent - between this final passage and many parts of the Philosopher's monologues, which reappears in Marrāsh's newspaper articles and other writings in his 'own' voice (some of which are discussed below). It is in this tone that we see most clearly the distance between utopian aspiration and Ottoman-Aleppine actuality, with which Marrāsh had to deal: a distance which he attempts to bridge with his projected voice, in exhortation and hope - and, later, biting criticism and despair. Similar attempts were to recur in Arabic writing: from the utopian imagery of Farah Anțūn, the Iraqi 'dream writers' of the

580 'Bunyat al-Lugha al-Sardiyya fī "Ghābat al-Haqq", 207. 
$1910 \mathrm{~s}^{581}$ or 'Romantics' such as Mīkhā'îl Nu 'ayma, to the resurrection trope of Muwaylihị̂’s Hadìth 'İsa ibn Hishām and its imitators, such as Manfalūṭị's al-Ba'th, around the turn of the twentieth century.

\section{The Natural and the Moral; Law and Freedom}

The second framework within which Marrāsh's utopian vision of 'civilisation' is set is the intellectual one of a single 'cosmic' vision of both the human and the natural worlds. The initial question posed to the Philosopher, about 'freedom', elicits a long discourse, not initially about human freedom but about the laws of nature, which render all of creation essentially unfree (or, as we might now say, determined). The slender opening of 'a kind of freedom', a 'moral freedom', for humanity, then leads the Philosopher on to a consideration, once again, of laws: human, political laws, and their development in history ('Statecraft and Kingdom'), down to the present (with America). These laws, whereby human freedom can alone be guaranteed, are then revealed, prescriptively, in the 'Pillars of Civilisation' and the Philosopher's judgements on the defeated 'Captains of Evil'. While freedom is therefore - as Rotraud Wielandt and others have argued - crucial to Marrāsh's thinking in Ghābat al-Haqq, it is not quite so central as has sometimes been suggested. Freedom is hedged about, here, with laws and determinations: freedom for Marrāsh consists (as Yūsuf Salāma, for instance, has pointed out $)^{582}$ in the recognition and acceptance of necessity.

Marrāsh's engagement here, within the same work, with both 'humanistic' questions and with a whole range of natural sciences, including medicine, is striking. If we may take two

581 See Hafez, The Genesis of Arabic Narrative Discourse, 140-2.

582 ‘Al-Ḥurriyya fī Fikr Fransīs al-Marrāsh', in Fransīs Fathallāh Marrāsh Rā’idan Nahdawiyyan waTanwīriyyan Baynanā, ed. Muhammad Jamāl Bārūt and Īmān al-Ṣālị̣, 113. 
English examples, Marrāsh's enterprise can be compared, in its ambition to bring within a single vision questions of natural and of human determination and freedom, with Shelley's in Queen Mab and its notes - or, later, and under the star of Marxism, that of Christopher Caudwell. ${ }^{583}$ As well as his studies with Wortabet and in Paris, we know that Marrāsh wrote, early on, a compilation on physics, as well as 'humanistic' work and poetry; this range persists in his later work, in the newspaper articles and Mir'āt al-ahwāl. This wide range of reference can be related to the wide interests of his Aleppine milieu: Jibrā' $\mathbf{1} l$ Dallāl's Minhāj al- 'ilm (Programme for Science), published in the same year as Ghäbat al-Haqq, offers a notably broad scope for human knowledge, encompassing natural and human - as does Marrāsh's account of 'the Cultivation of Reason' (Tathqīf al- 'aql) in Ghābat al-Haqq.

But this engagement with issues of the natural world should be situated also in the wider context of the Nahda, beyond Aleppo. Marrāsh's treatment of geography, politics and laws, morality, the succession of human civilisations in history fits into the context we have been examining: the civilisational discourse of Bustānī, Ṭahtāin̄i, or Khūrī. But for his engagement with the natural order - the $\operatorname{tab}^{\top} \hat{\imath} \bar{l}$ in addition to the $a d a b \bar{l}$, in the distinction he draws - we must look, largely, to another range of predecessors and contemporaries: not the familiar Nahda pioneers of Hourani, but a less well-studied series of 'scientific' enlighteners. In the generation preceding Marrāsh, this group includes - in addition to members of the ‘Aleppo Circle' - his mentor John Wortabet, Mīkhā’īl Mishāqa and Salīm Nawfal; ${ }^{584}$ further back, we might look to the Egyptian translators of medical works under Mehmed Ali and his successors, ${ }^{585}$ and to 'Isa Petro of the Damietta Circle, author of a work on physics as well as compiler of a treatise on the sciences from European sources. ${ }^{586}$

583 See the account in Thompson, 'Caudwell'.

584 See the papers by each of these in the first set of Proceedings of the Syrian Society for the Acquisition of

Sciences and Arts: Buțrus al-Bustānī, ed., A 'māl al-Jam 'iyya al-Sūriyya, vol. 1 (Beirut: American Press, 1852).

585 Zaydān, Tārīkh Ādāb al-Lugha al- 'Arabiyya, 4:191-204.

586 Hill, 'The First Arabic Translations of Enlightenment Literature'. 
This engagement with matters scientific was to press on, in the $1880 \mathrm{~s}$, to the famous controversy over Darwinism. ${ }^{587}$ At the time of Marrāsh's participation in it, however, science and religion appeared as allies rather than enemies. As Mishāqa wrote of his youth:

I believed that when I learned about them, the secrets of the universe would be unlocked to me. I thought that if the Prophet David's words were true that "the firmament showeth His handiwork," then astronomy would tell me everything the Creator had done and would do. My limited understanding and narrow learning led me to believe any such fables. ${ }^{588}$

Van Dyck had projected an Arabic translation of Paley's Natural Theology; ${ }^{589}$ and Marrāsh himself produced, at some point in his career, a work entitled Shahādat al-țabi' a 'ala wujūd Allāh wa-l-sharì'a (Witness of Nature to the Existence of God and the Law). ${ }^{590}$ Marwa Elshakry has given further evidence of the largely complementary manner in which science and religion were viewed, in American missionary circles and those influenced by them. ${ }^{591}$

There was then no overt opposition, when Marrāsh was writing, between 'science' and 'religion'. But natural theology was not in fact the principal way in which, in Ghābat alHaqq, he chose to relate the natural and the human worlds. Rather, this was by way of the concept of law, and an analogy between the laws that govern nature and those that govern human societies. Again, he was not alone in this: from his own Aleppo circle, Nașrallāh Dallāl's Athmār al-tadqīq (1881) is precisely a book-length attempt to illustrate the necessity of laws for human society, by analogy from those governing animals, vegetables and

587 Elshakry, Reading Darwin in Arabic, 1860-1950. Among those who resigned from the Syrian Protestant College in sympathy with Dr Lewis, who had referred to Darwin's ideas in his inaugural lecture, were John Wortabet and Cornelius Van Dyck (though Wortabet was later persuaded to return in some capacity). 588 Mikhā’̄il Mishāqa, Muntakhabāt Min al-Jawāa 'alā Iqtirāh al-Ahbāb (Beirut: Ministry of Education and Arts, 1955), 62-63; translation adapted from Thackston, Murder, Mayhem, Pillage, and Plunder: The History of the Lebanon in the 18th and 19th Centuries by Mikhayil Mishaqa (1800-1873), 96-97.

589 Abdul Latif Tibawi, American Interests in Syria, 1800-1901: A Study of Educational, Literary and Religious Work (Oxford: Clarendon Press, 1966), 126.

590 This was certainly printed by the American missionaries after his death, in 1891/2, after being serialised in their periodical al-Nashra al-usbü iyya). Karam al-Hulw and others also mention an Aleppo edition of 1871 which I have yet to see: al-Fikr al-Lìbrälī, 272.

591 Marwa Elshakry, 'The Gospel of Science and American Evangelism in Late Ottoman Beirut', Past \& Present 196, no. 1 (2007): 173-214. 
minerals. ${ }^{592}$ And this points to an engagement, less with natural theology than with that other set of questions raised by Enlightenment debates around free will and determinism, within an ordered, law-governed system of nature. Both in the order of the Philosopher's discourses and in his programme of education (Tathqif al- 'aql), the natural world comes before the human; and in the relationship between the two he stresses humanity's powerlessness before nature:

Still, it is possible for Man (al-Insān) to attain a kind of freedom, and to enjoy the pleasure of life after a fashion. As regards his attaining of freedom: this is possible only if he comprehends that the flaring of his existence, however numerous it may be, in relation to the nothingness that preceded it and which shall replace it, is like a tiny lightning-flash that shone out in a dark night. And that all the vicissitudes and sorrows of the world surround this meagre period of life, from which must be deducted the times of his sleeping, his childhood and old age, which amount to nothingness. And that all his surroundings attempt to destroy his frame, to take back from him by force the materials that he stole from them. And theft is forgiven only by returning [what was stolen], which is the judgement on the one who seized [them]. ${ }^{593}$

This shows the extent of Marrāsh's engagement with the problems raised by materialist, determinist, or necessitarian questionings - his position in this passage, in its stress on the powerlessness of man before an (at least potentially) hostile natural order, bears comparison with, for instance, that of Leopardi in La Ginestra. ${ }^{594}$ The emphasis on 'surroundings' or 'environment ${ }^{595}$ is reminiscent of Enlightenment materialism. ${ }^{596}$ And Marrāsh's Philosopher has to defend himself against accusations of pantheism as well as materialism. After his

592 al-Humșī, Udabā' Halab, 60.

593 32-33; 26.

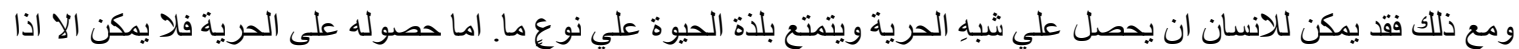

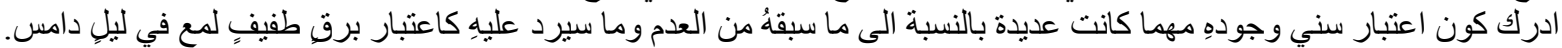

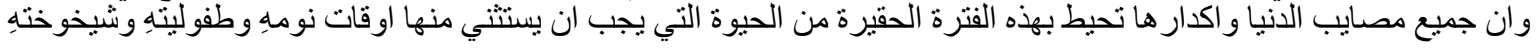

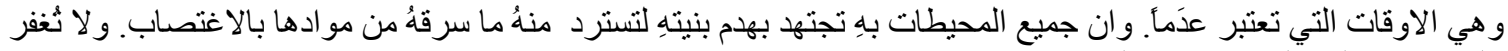

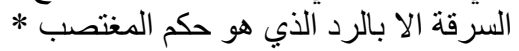

594 See Sebastiano Timpanaro, 'The Pessimistic Materialism of Giacomo Leopardi', New Left Review 116 (August 1979): 29-50.

595 See also 29; 23: sulțān al-muhītāat bihi 'alayhi.

596 For the French debates of the 1750s, involving La Mettrie and Diderot, see Ann Thomson, Bodies of Thought: Science, Religion, and the Soul in the Early Enlightenment: Science, Religion, and the Soul in the Early Enlightenment (OUP Oxford, 2008), 212; for the most influential early nineteenth-century medical development of mechanical materialism, see Martin S. Staum, Cabanis: Enlightenment and Medical Philosophy in the French Revolution (Princeton: Princeton University Press, 1980); for the British tradition from Bacon to Hartley and Priestley, see Roy Porter, Enlightenment: Britain and the Creation of the Modern World (London: Penguin, 2001). 
account of 'Love' (al-Mahabba) as a Providence's law for creation, he mentions possible

objections:

Some scowl and say: See, he infers from this the divinity of the motion of created things. Others turn up their noses and say: Ha! Ha! All that can be deduced from this talk is that the Word is mixed materially in the generality of created things. And yet others stare, and scream: This is the doctrine of the materialists (al-mädiyyin) itself! And this is not to mention those who will spread out their beards and say: How is it permitted for one who has not crossed the threshold of a school to speak theologically of a thing that his understanding does not encompass? And by what rule has he proved the determination of the active force upon the passive force, and torn down things spiritual with things material? ${ }^{597}$

The Philosopher has already concluded his account of the natural world by re-embracing religious truth: amazed at the works of nature, he says, we can be 'taken by the intoxication of imaginings and illusions' ( ma 'khüdhan min khamrat al-hawājis wa-l-awhām). ${ }^{598} \mathrm{We}$ contemplate the properties of matter and seek for the cause of its motion and life: first he suggests that each being has a 'particular life' (hayātun khușūṣiyya) and a 'general life' ( 'umümiyya) shared with other things. Then he offers as possible causes: electricity (alkahrabā'), 'the flowing of heat' (sayyāl al-harāra: perhaps conduction), 'light' (al-nūr), 'the law of gravity' (sharī'at al-tathāqul), and 'endless space' (al-fid̄à' al-ghayr al-muntahì). ${ }^{599}$

With all of these in turn, he says, we are unsatisfied: but finally we hit upon

a Lord far beyond the comprehension of [our] understandings, ever concerned with the regulation of all these creatures; from Him was life, and without Him was not any

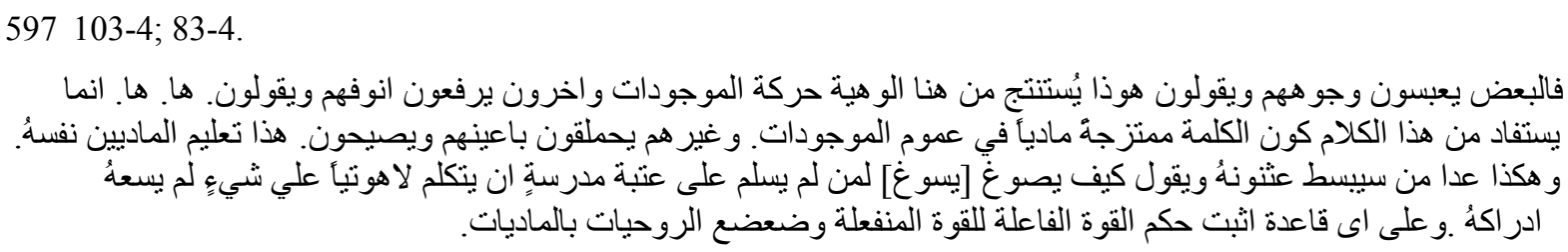

The Philosopher answers these objections thus: 'what is meant by the claim of universal Love is not that it is the Divine Essence itself spread amongst the particles of Creation but that it is the force by which that Essence moves the creatures and regulates beings' (104):

$$
\text { المر اد من دعوى الخحاديق ويدبر الكايناتة ليس كونها هي نفس الجوهر الالهى منوزعاً في جزعيات الخليقة بل كونها القوة التي بها ذلك الجوهر }
$$

This is turned in the Beirut edition into 'the force which God made to move the creatures and regulate beings'

(84: al-quwwa allatī ja 'alahā Allāh li-taḥ̂̄k al-khalā' iq wa-tadbīr al-kā'inat) - perhaps a linguistic

emendation, but possibly an attempt to make the original more orthodox (God creating 'Love', as opposed to the more abstract, possibly deistic, 'that Essence' which moves the creatures by Love).

$59837 ; 30$.

$59937-8 ; 30-31$ 
thing, that was made. He is the mover of the motions, the origin of beings, and to Him all things return. There is no God but He, and nothing but Him is worshipped. And instantly we are satisfied with this proposition, and withdraw all our thoughts from the positions of strange illusions and doubts, embracing the bride of truths and the firstborn of all Creation, enjoying the pleasure of life and the freedom of existence. ${ }^{600}$

Thus the 'imaginings' (hawäjis) of materialistic theories of nature are recuperated into natural theology (which is, moreover, ecumenical, drawing on the language of both John's Gospel and the Shahāda). In the context of so much uncertainty and ignorance about nature and man, it seems reasonable to settle back into the received truths of revealed religion. This overlaps with the argument, in the Trial, between Knowledge and Ignorance: Civilisation must leave some space to Ignorance because what we know will always be meagre by comparison with what we do not know. ${ }^{601}$ Mishāqa, in 1853, had argued along similar lines against overconfidence in human reason, culminating in an argument similar to Pascal's: if sceptics cannot prove that religion is false, it is prudent to assume its truth. ${ }^{602}$ But there is a sense in which the power of these hawajjis to unsettle has been demonstrated, despite the Philosopher's protestations of faith. In that moment of recuperation, the existence of God had been offered, not as unquestioned fact, but as a possible theory - like electricity or gravity - to explain the properties of matter.

\section{'The Spirit'; History, Polities and Laws}

There is a similar ambiguity in Marrāsh's approach to the 'Kingdom of the Spirit', inserted

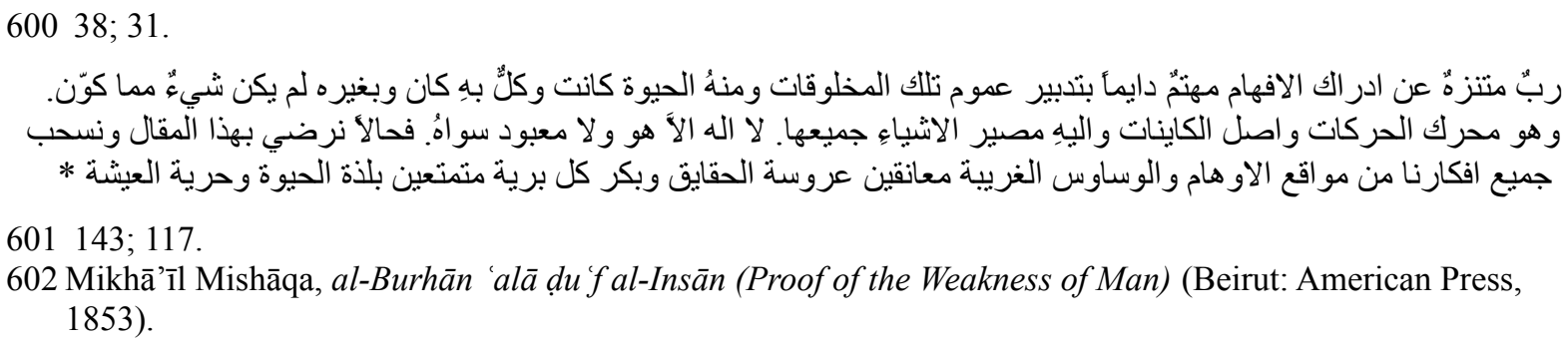


between the Philosopher's first account of the natural world and that of the human world ('Statecraft and Kingdom'). This is a question that has been much discussed, often in the form of: was Marrāsh a secularist, or seculariser? Authors have reached widely differing conclusions: Hourani includes him in his chapter on 'Christian Secularists' in Liberal Age; while Wielandt refers to him as a 'champion of a firm ecclesiasticism' (Verfechter einer dezidierten Kirchlichkeit). ${ }^{603}$ The fairest account of the question is perhaps an unpublished one by Johannes Stephan. ${ }^{604}$ The discussion departs, we recall, from a description of the Kingdom of the Spirit - a notably vague formulation, as opposed to, for instance, 'the Church' or 'Religion' - as a large kingdom contiguous to the Kingdom of Civilisation. The King of Freedom, expressing fears of subversion perhaps reminiscent of the vigorous Etat lä̈ of the French tradition, suggests annexing it; the Philosopher dissuades him by showing the true harmony between the two Kingdoms. His statement that there is no enmity between the Kingdom of the Spirit and that of Civilisation has been read, for instance by Yūsuf Salāma, as meaning that the two Kingdoms are in fact one; and that Marrāsh, accordingly, has a basically religious notion of human civilisation. ${ }^{605}$

It is true that certain of Marrāsh's statements ${ }^{606}$ lend themselves to Salāma's conclusion that, for Marrāsh, 'the spiritual element has the final victory (al-ghulba al-nihā'iyya)' ${ }^{607}$ But again I think we have to see the ambiguity of his formulations. The Kingdom of the Spirit is rendered in so abstract a fashion that it need not (though it could be) taken as referring

603 Wielandt, 'Marrâsh Und Die Aufklärung', 141. Salāma, 'al-Ḥurriyya fī Fikr Fransīs al-Marrāsh', though expressing himself in less strong terms, also concludes that Marrāsh opted, in the end, for religion. 604 'Aspekte Des Tamaddun'.

605 'Al-Hurriyya fī Fikr Fransīs al-Marrāsh', 107.

606 E.g. when the Queen says: 'for the higher governance (al-siyāsa al- 'alawiyya) is victorious always over the lower (al-sufliyya), and that which descends from above dominates that which rises up from below, and what is performed by chance is not victorious over the deeds of intention.' $(49 ; 40)$.

لان السياسة العلوية منتصرةٌ دايمأ علي السفليّة. وما يكون هابطأ من الاعالى يسطو مطلقأ علي ما ينهض من الاسافل. وما تفعلهُ

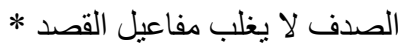


directly to any existing religious establishment. And though the divine (or perhaps the 'higher') is an active force throughout Ghäbat al-Haqq, acting on natural and human affairs through the agencies of Providence (al- Ināya) and Love (al-Mahabba), it is never, outside the section on 'the Kingdom of the Spirit', referred to as acting through 'spiritual' agents: organised religions or clerics. Rather, it is seen as a force animating nature and providing divine (and natural) laws for human civilisation - but these are seen as operating through material causes (for nature) and through human and secular ones (for civilisation). There is nowhere a mention of organised religions or priesthoods in the account of the growth of political authority and states - though there are descriptions of the growth of secular knowledge of nature and of technique or industry. ${ }^{608}$ No representative of the 'Kingdom of the Spirit' speaks or is present in the court of Civilisation, and it is the Philosopher who gives advice to the court and judgement on the prisoners. He refers in one place to the need, among the Arabs, of a 'love of country free from religious prejudices (mahabba wațaniyya munazzaha 'an aghrāḍ al-dīn), ${ }^{609}$ a formulation we have seen in Bustānī (Chapter 2). His uses of religious phrases draw equally, it seems, on the Quran and the Bible - suggesting an ‘ecumenism' again similar to Bustān̄̄'s ${ }^{610}$ - and in places suggest Enlightenment deism or toy with paganism. ${ }^{611}$

Even the Philosopher's pleadings against the invasion of the Kingdom of the Spirit are built

608 There is, however, a brief mention of primitive man worshipping the thunder as a god (53; 43). Later, superstitions about the planets are traced to the beliefs of the Ancient Greeks $(97 ; 78)$, and certain superstitious customs to those of the Arabs of the Jahiliyya (94; 76); compare Mishaqa's paper in Bustānī, A'māl al-Jam 'iyya al-Süriyya, 1:50-58. This gestures towards a secular history of at least some religious and magical beliefs.

$609138 ; 113$.

610 Ja far, "Bunyat al-Lugha al-Sardiyya fī "Ghābat al-Haqq"' cites many examples: 207; Wielandt, "Marrâsh Und Die Aufklärung', 136, merely finds this a little odd, and explains it in terms of Marrāsh's familiarity with the Arabic literary heritage (mostly written by Muslims). But within the context of writings of Bustān̄ and others it comes to look like a more deliberate ecumenism. Cf. Yasir Suleiman, The Arabic Language and National Identity: A Study in Ideology (Edinburgh: Edinburgh University Press, 2003), on similar, later uses by Khalīl al-Yāzij̄̄.

611 Thus Love is the Goddess of Society, and 'If an idol were to be erected to her in the Temple of the Mind, it would be in the form of a girl, all beautiful, without blemish [.... ' $(105 ; 85)$.

$$
\text { ولو أقيم لها وثنّ في هيكل الذهن لكان على شكل غادٍٍ كاهل جميلة وليس فيها معاب [....] }
$$


on secular maxims of policy more than they are on 'spiritual' arguments. ${ }^{612}$ And he has to defend himself, as we have seen, against possible criticisms from religious authorities among other things, of his lack of qualification to speak 'theologically' (lāhütiyyan). If Marrāsh, or the Philosopher, offer themselves as speaking of or for the divine, this is potentially an infringement on the unique claims of the official representatives of the 'Spirit'. The final effect, I would suggest, is ambiguous (and perhaps inconsistent): Marrāsh concludes a pact of non-aggression and harmony between the Kingdom of the Spirit and that of Civilisation, but then goes on to discuss the latter without reference to the former in any distinct form, separate from the divine laws of nature and civilisation as expounded, not by clerics, but by the Philosopher. This accords with the picture given by Bārūt of Marrāsh's Aleppo circle, as a mainly lay group with cultural, literary and scientific interests - though of course in close contact with religious establishments and to a large extent educated in Christian schools. ${ }^{613}$

The Philosopher's discussion of the 'Kingdom of the Spirit', as a separate domain, can thus be seen as something of a detour - on which Marrāsh must nevertheless venture, in order to make clear his non-aggression towards religion. But the principal contexts in which his prescriptive, utopian vision are set are two: nature and human affairs. This second frame requires less extensive comment, for we can recognise many of its aspects as shared with writers we have already considered: Țahțāwī, Bustānī, Khūrī. We should note two points: first, Marrāsh's presentation of history is rather more systematic and abstract than is often found in other Nahda writings. The succession of civilisations - mainly Ancient, but leading up to the modern day - is first encountered in the 'Prologue', and then repeated briefly in

$612 \mathrm{He}$ argues, for instance, that religion serves to protect the rich from the poor, and curb criminals $(47 ; 38)$; and that the Spirit is simply too powerful to defeat $(48 ; 39)$.

613 His suggestion of a major rift between the Aleppine bourgeoisie and the clergy (based on the single example of a dispute between the Kubba family and the Maronite hierarchy) seems less certain, though he is right to stress the independence of these merchant and 'Enlightenment' circles from the clergy: Harakat al-Tanwīr al- 'Arabì, 19-20. 
'Statecraft and Kingdom' and at greater length in the programme of education offered in the

'Cultivation of Reason'. ${ }^{614}$ This last (an account of the destruction of states) is introduced

with a passage that recalls both Kharābāt Süriyyā and the ruminations of Volney:

When he [the person being educated] mounts his secret contemplations, the steeds of history, and goes around the Syrian Desert, for example, where he perceives that the greatness of that region, ancient and beneficent in soil and origin, has been transformed by the action of the harsh ages into terrible destruction, where nothing is to be seen but ruins grievous to behold, and a small number of impoverished peoples, in the place of those former greatnesses, that shining glory and plentiful wealth. ${ }^{615}$

Though it has a local, Near Eastern focus, it is presented as a general sequence, belonging to what he in one place calls 'general' or perhaps 'universal' history (al-tārīkh al- 'âmm). ${ }^{616} \mathrm{We}$ also encounter, in the 'Prologue', general principles of development: the banners inscribed 'Reason reigns' (al- 'Aql yahkum) ${ }^{617}$ and 'Knowledge conquers' (al- 'Ilm yaghlib). ${ }^{618}$ This is universalising, 'philosophic' history, driven by unitary principles, of the French philosophe variety. ${ }^{619}$ The Philosopher, of course, believes in the reformability of the Kingdom of Slavery through the laws of Civilisation; ${ }^{620}$ in introducing his exposition of history in the Cultivation of Reason, he asserts that people's conditions are the result of their actions, which is why history may serve as a lesson for the present; ${ }^{621}$ the vocabulary of 'progress', taqaddum, has evidently reached a 'stronger' form than that in which we saw it in Khalīl al-

$6142-5 ; 2-4,66 ; 53-4$, and $85-6 ; 68-70$ respectively. There are many other references to Antiquity and the Biblical world: $18 ; 15,22 ; 17,23 ; 18,39 ; 32,61 ; 49,97 ; 78,148 ; 121$. $61584-5 ; 68$.

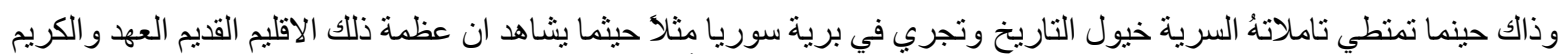

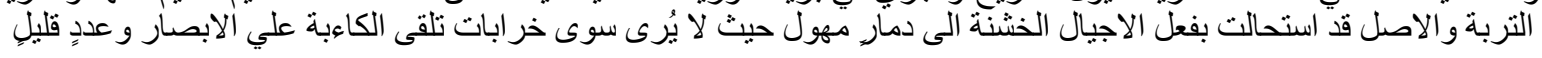

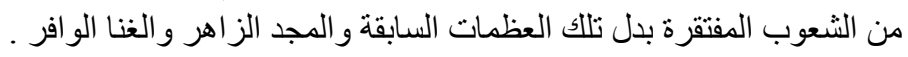

$61651 ; 42$. Jibrā'̄îl Dallāl was said to have written an incomplete risāla or summary on this topic: al-Humșī,

Udabā' Halab, 12; Cheikho, al-Ādāb al-'Arabiyya fí al-qarn al-tāsi' 'ashar, 148.

$6174 ; 3$.

$6184 ; 4$.

619 Wielandt's invocation of Condorcet and the Tableau des progrès de l'esprit humain ('Marrâsh Und Die

Aufklärung', 135) is in this case justified. But we should also note that 'philosophic history' had already been defined in the preface on the history of historiography, of unknown but probably French provenance, which Khalīfa b. Mạ̣mūd added to his translation of Robertson's A View of the Progress of Society in Europe, itself in fact a development away from the unilinear, universal history of the French philosophes, or Hume. See David J. Womersley, 'The Historical Writings of William Robertson', Journal of the History of Ideas 47, no. 3 (1986): 497-506.

$62069 ; 56$.

$62183 ; 67$. 
Khūrī's introductory letter to Hadīqat al-Akhbār in 1858 (Chapter 2). And of course Ghäbat al-Haqq ends by hailing the new era of civilisation about to open in Syria itself.

This optimism about human progress and improvability remains, however, in an unresolved tension with other, more pessimistic views of history. One is voiced by the pessimistic Minister of the Love of Peace, in the discussion of war and peace (in 'The Dream') before the arrival of the Philosopher. He offers a paean to peace, in terms reminiscent of Nafir Süriyyā:

by peace the society grows, the circle of its progress widens in wealth, knowledge and morals. With peace the fields are fertile, the earth gives its crops, agriculture improves and harvests are plentiful. By peace the country and villages prosper, and trade broadens, which is the axis of intercourse with the whole world. [.... $]^{622}$

This is followed by an attack on its opposite, war. But then he adds:

Despite all this, peace may give rise to wars and wars to peace. Since the increase of ease may create manifold evils which are only removed by means of hardship and exertion. And so too the increase of hardship may cause numerous evil symptoms which can only be subdued and eliminated under the rule of ease and calm. ${ }^{623}$

The case is brought closer to home by the example the Minister then gives: that peace (the good treatment of the Kingdom of Slavery, by his advice) has now given rise to war. But the argument around ease and hardship appears related to the Khaldūnian cyclical view of history. ${ }^{624}$

These doubts of the Minister may perhaps be discounted as occurring before the Philosopher arrives to enlighten him. Yet the Captain of the Army of Civilisation is still sceptical even $62219-20 ; 15$.

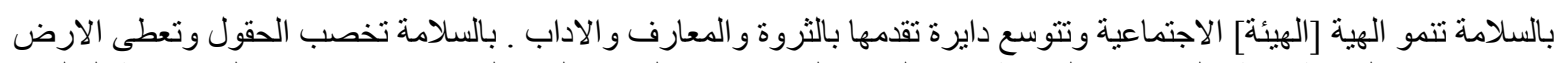
غلاتها وتجود الفلاحة ويكثر الحصاد ـ بالسلامة تعدر البلاد والقرى وتتسع التجارة التي عليها يقوم مدار الاشتر الك مع كافة العالم . $62320 ; 16$.

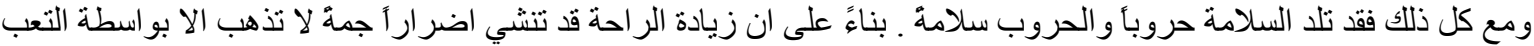

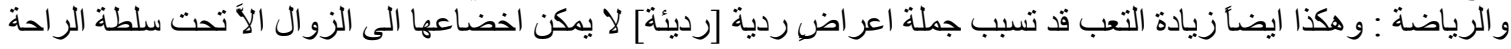

$624 \mathrm{Cf}$. the Khaldūnian desert/settled vocabulary used in the account of the development of government: peoples came to the city 'to flee the trials of the desert and attain the comfort of settled life' $(62 ; 50)$.

لكي يتخلصو ا من مشاق البادية ويفوزوا بر احة الحضر 
after the Philosopher's lengthy exposition of tamaddun:

But I still regard its [Civilisation's] spreading among the peoples of the Kingdom of Slavery as extremely difficult and arduous, even if its Pillars are planted in the heart of Natural Man; it is indisputable that, if corruption begins to spread in any place, and establishes itself, especially over the course of many years, reforming it is then in vain. How can wine be improved if it has turned to vinegar? ${ }^{625}$

The Philosopher of course thinks otherwise, and the King follows his advice; but as on other questions, due to the dialogic nature of the text, the doubts of other characters are not wholly subdued to the Philosopher's monologue, and a certain ambivalence remains. Man has, after all, in his relation to nature (including his own nature) been shown to be a deeply limited and perhaps (in the Kingdom of the Spirit) a fallen creature.

\section{The Philosopher and the King}

Many of the aspects of the Philosopher's utopian vision of tamaddun we have already seen foreshadowed in other Nahda writers - although Marrāsh's is perhaps the fullest and clearest single statement of what 'tamaddun' meant to be produced in the middle decades of the nineteenth century. Only the focus on the political (the first Pillar) is a little unusual, for reasons we shall examine. But the emphasis on education (the second Pillar), including the education of women, is familiar from writers (and educators) like Bustānī and Ṭahțāwī, only cast in more 'Enlightenment' terms (the Cultivation of Reason) and given a comprehensive and secular programme. 'Manners and customs' as a component of tamaddun are again familiar, from a different set of writings: the emphasis found in Khalīl al-Khūrī's Way, idhan lastu bi-Ifranjī, Salim al-Bustānı̄'s romances on personal and social behaviour, or of others

625 114-5; 94.

ولكنتي لا ازال ارى انتثارهُ بين شعوب مملكة العبودية عسر آ وشاقَ في الغاية ولو كانت دعايمهُ مرتكزةً على قلب الانسان الطبيعي.

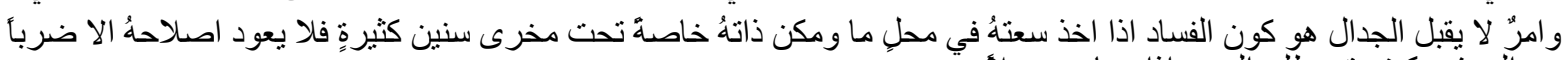
من العبث : كيف تصطلح الخمر اذا صارت خلاد الخاد 
who wrote on domestic affairs. 'The health of the city' (the fourth Pillar) fits with both the traditional (Khaldūnian) emphasis on settled, city life (preserving buildings against the ravages of time), and with the new preoccupation with town planning and civic reform (widening of streets), well described for Beirut by Jens Hanssen. ${ }^{626}$ There is also a particular emphasis - derived doubtless from Marrāsh's work with Wortabet - on health and medicine: both hygiene (al-nazāa $f a$ ) and town planning as a cure for certain kinds of disease. ${ }^{627}$ The fifth Pillar, Love (al-Mahabba), again has its precedents in the medieval Arab philosophers, as a component of human society (al-i'tinās/al-ijtima $\bar{a}^{\prime} a l$-insān $\left.\bar{l}\right)$, and in the reworking of their tradition by Nahda writers like Bustānī (as we have seen); as well as in Enlightenment and Christian notions of divine and brotherly love. ${ }^{628}$

The concern, in the Trial, with specific bad and good qualities may be related in one sense to religious traditions of virtue and vice; but in another to the Enlightenment notion of the relationship between vice or virtue and the overall health of societies or polities. ${ }^{629}$ This is explicitly referenced in the Philosopher's account of the decline of states, where the ruin of Ancient nations is attributed to specific vices: harshness (al-qasāwa) sank the ships of Egypt; negligence (al-taghafful) destroyed the Persians, and so on. ${ }^{630}$ In this sense, the 'public' and 'private', although separated out from each other (into public and private

626 See Hanssen, Fin de Siècle Beirut, esp. Chs. 3-5. It would be interesting to compare Marrāsh's own views of Beirut's 'civilisation', as well as that of Europe, in Rihlat Bāriss.

627 Rev. John M'Kerrow, History of the Foreign Missions of the Secession \& United Presbyterian Church (Edinburgh: Andrew Elliot, 1867), 502 mentions Wortabet's medical efforts in Aleppo and its hinterland around this time; This was a continuing concern of Wortabet's: in 1891 he was reporting on the eradication of cholera through civic hygiene measures in Aleppo. Robert Ian Blecher, 'The Medicalization of Sovereignty: Medicine, Public Health, and Political Authority in Syria, 1861-1936' (Doctoral dissertation, Stanford University, 2002), 84-85.

628 Māhir al-Sharīf, 'Ru' yat al-Marrāsh li-l-Tamaddun fì Ițār Khițāb 'așr al-Nahḍa', in Fransīs Fathallāh Marrāsh Rā'idan Nahdawiyyan wa-Tanwīriyyan Baynanā, ed. Bārūt and al-Șāliḥ, 69-92; and Wielandt, 'Marrâsh Und Die Aufklärung', both trace the concept of 'mahabba' in Marrāsh to Christian influence. But the term had been used in the context of human society (uns, madaniyya, etc), for instance by Miskawayh; as well as by the Christian faylasū f Yahyā ibn 'Adī, 893-974 AD, pupil of Fārābī and translator of Aristotle. See Black, History of Islamic Political Thought, 70, 58.

629 Bustānī used the vocabulary of social vices and virtues in Nafir Süriyya, as we saw in Chapter 2 (pp. 103,110), as did Khūrī on the 'English Nation' (above, pp. 203-4).

$63086 ; 69-70$. 
'customs and morals', in the Third Pillar of Civilisation) are in fact intimately connected.

The relationship between different vices and virtues is regulated, in the Trial, by the

Philosopher, speaking in the name of the State of Civilisation (which has just conquered the rebellious vices). This points to a prominent feature of Ghäbat al-Haqq: although its vision of civilisation and of human affairs is a comprehensive one, this has nonetheless a regulating centre, and this is in politics and the state.

This is already evident, before the explicit description of tamaddun is reached - first in the fact that the whole narrative opens with an allegorical court, engaged in the state's traditional primary function of war. There is then the title of 'Statecraft and Kingdom', and the fact that this section, accordingly, although it includes industries, arts, and other areas of society, consists mainly of an account of the origins of government. It is suggested that this is a parable of the imagination, illuminating but not literally true. ${ }^{631}$ We have of course seen a similar kind of parable of the origin of human society, in the passage of Bustānī’s, perhaps adapted from Ibn Khaldūn, in al-Hay'a al-ijtimā 'iyya; and Robinson Crusoe's creation of an economy from scratch on his island has been read in a similar way. ${ }^{632}$ But it is worth dwelling a little on the differences between an account of the origin of society and the division of labour, and an account of the origin of government or kingship. Both have 'Enlightenment' precedents; but the former, as in the political economists, tends rather to ignore the state, or to see it as secondary to human society and economic matters; whereas the second takes the political and the state as central. It belongs less to political economy than to that other Enlightenment emphasis on states, laws and constitutions. ${ }^{633}$ Even the

$63160 ; 49,65 ; 54$.

632 See, for instance, Ian Watt, 'Robinson Crusoe as a Myth', and Maximilian E. Novak, 'Robinson Crusoe and the State of Nature', in Daniel Defoe, Robinson Crusoe, ed. Michael Shinagel, Norton Critical Edition, 2nd edn (New York and London: Norton, 1994), 288-305, 309-319; in relation to Bustān̄’s translation, see Bou Ali, 'Hall of Mirrors', 141-2, $145 \mathrm{ff}$.

633 This could subsume the origins of society and the division of labour into itself, as for instance in Volney, The Ruins, Chs. VI-IX: 'The Primitive State of Man', 'Principles of Society', 'Sources of the Evils of Society', and 'Origin of Government and Laws'. 
constitution of nature is 'state-like', in Ghäbat al-Haqq, in the sense that it is governed by law; and the analogy is used (as, later, in Dallāl's Athmār al-tadqīq) to point the necessity for a law, that of Civilisation, to govern human affairs. And the first Pillar of Civilisation is 'The Refinement of Politics':

Since the rotation of the system of the human world can only be kept preserved from any rupture [or: disorder, defect, imbalance: khalal] by managing it (siyāsatihi), this law $\left(\operatorname{shari~}^{-} a\right)$ requires full attention to its refinement and improvement, as it is an axis around which turns a great world, the ordering of which which deserves attention. ${ }^{634}$

The stance of Marrāsh's Philosopher, then, is one of close interest and involvement in affairs of state, both in terms of advice to the rulers and of judgement upon the ruled. But this involvement is one which holds the state and court, nonetheless, somewhat at arm's length: the Philosopher travelling in upon a summons from the City of Light, rather than being a member of the initial court circle; his advice given as that of a wise outsider, supported by some (the Queen and Minister of the Love of Peace) within the court more than others (the King and Captain of the Army of Civilisation). Above all, his abstract discourses on freedom and determinism, history and the origins of the state, and even that on civilisation, for all its apparent character as a blueprint, transcend the immediate concerns of the rulers and point less towards a practical manual of advice than towards a generalised theory of both the $\operatorname{tab} \bar{\imath} \hat{l}$ and the $a d a b \bar{\imath}$. This stance - involved in the deliberations and decisions of rulers, but maintaining a deliberate distance and more general theoretical or scientific aspirations, as well as a readiness to make occasional, guarded criticisms - is one for which many precedents can be found in earlier Arabic, as well as Classical and European, traditions. It can be found in the Sassanid tradition brought into Arabic with Ibn al-Muqaffa ${ }^{c}$; ${ }^{635}$ it is there

\footnotetext{
$63471 ; 58$.

انهُ لما كان مدار نظام العالم الانسانى لا يمكن توقفه محفوظأ من كل خلٍِ الا علي سياستهِ. كانت هذه الشربعة تقتضي تمام الالتفات

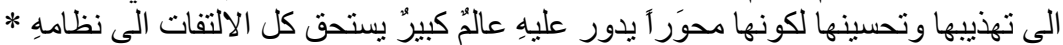
635 See for instance István Kristó-Nagy, La Pensée d'Ibn al-Muqaffa . Un «agent Double» Dans Le Monde Persan et Arabe, Studia Iranica, XIX (Versailles: Éditions de Paris, 2013); and Sulayman Al Bassam's excellent reworking of this moment in his 2006 play: The Mirror for Princes - Kalila Wa Dimna (London: Oberon, 2006).
} 
too in the classic attitude of Muslim ulama to the temporal power: their endorsement of the principle of authority but suspicion of actual rulers (and of ulama in rulers' service). ${ }^{636}$

The attitude to royal power of Sir Thomas More, as described by Morton, ${ }^{637}$ is recognisably similar, as is that of Fénelon, preceptor to the son of the great absolutist Louis XIV, in his Télémaque, which was appearing in Ṭahṭāwī’s translation in Hadīqat al-Akhbār from 1861, through the years when Marrāsh probably composed Ghäbat al-Haqq. Some of these literary predecessors were likely to have been important for Marrāsh, as influences - Télémaque almost certainly, Kalīla wa-Dimna or works of its tradition very probably, though perhaps not Fārābī or Thomas More in any direct way. But more than these potential literary influences, to understand the overall stance of Marrāsh and his Philosopher in Ghäbat alHaqq we should interrogate the social situation of the Aleppine circles to which he belonged, described above. For they may be seen as entertaining a similar arm's-length relationship with the Ottoman state, via its reformist officials: Fuad, Cevdet, Khayr al-Dīn al-Tūnisī. They had their own sources of education and cultural activity - Christian schools, European connections, majālis - independent of the state; but they aspired also, at times, to intervene in central Ottoman as opposed to local civic politics.

And, building on this, we may pursue the comparison initiated above between the intellectual circles of Aleppo, Cairo and Beirut, into the realm of the utopian and allegorical literature they produced. It is notable that Țahțāwī’s translation of Télémaque, which shares a good deal of the stance of Marrāsh's Ghābat al-Haqq, was undertaken during precisely that period when he was least engaged in the official translation and education movement - his exile in Sudan - and that, unlike the rest of his oeuvre, it was published not by that official

636 See for instance Zouhair Ghazzal, 'Chapter Four: The "Ulama”: Status and Function', in A Companion to the History of the Middle East, ed. Youssef M. Choueiri (Oxford: Blackwell, 2005), 72-86. 637 The English Utopia, 38, 50-51. 
movement's press at Bulaq, but by Khalīl al-Khūrī in Beirut. Whether or not we credit the oft-repeated suggestion of the translation's deliberate oppositional character, in response to his fall from favour and exile, we can certainly remark its lack of embeddedness in the institutions of the Egyptian state. Tahțāwī had developed, briefly, the kind of arm's-length relationship to government which both permitted work on a translation of less obvious utility to the state education programme than geography or law textbooks, and necessitated its publication through other channels.

As for the Beiruti intellectual circles, we can note three translations of quasi-utopian writings in the same period: Bustānī's retranslations of The Pilgrim's Progress (1844) and Robinson Crusoe (1861), and Salīm Șa 'b’s of Paul et Virginie (1863). All these are considerably less concerned with government, as such, than either Ghäbat al-Haqq or Télémaque, in its original French or in Ṭahțāwī's version: in the dramatic adaptation of Sa dallāh al-Bustānī, Fénelon's narrative also tends to shed its preoccupations with matters of state. The Pilgrim 's Progress is more concerned with matters of the spirit than with earthly government: the only ruler of consequence it involves is the ruler of Heaven. Defoe's novel is the story of a man who leaves behind the civilised states of Europe to set up his own autarkic economy on a desert island. This economy develops, it is true, state-like qualities, as Bustānī was aware in his translation, ${ }^{638}$ but the emphasis is on industry and production on the island, and on the trade networks which bring Robinson there, and which thus extend beyond the law-bound, civilised states of Europe or colonial America. In general, we may see Robinson Crusoe, like much of Defoe's work, as belonging to the emerging tradition of English - and Scottish political economy, aptly redescribed by Edward Thompson as 'more truthfully anti-political' economy: an 'economic protestantism' which 'did not threaten to overthrow the State: it

638 See Hill, 'Early Arabic Translations', 207. 
simply turned its back on it, leaving to it only vestigial functions ${ }^{939}$ - like those enjoyed by the monarch Robinson over his primitive kingdom, such as the guaranteeing of religious liberty. This may be contrasted, as Thompson implicitly contrasts it, with a Continental and above all French Enlightenment tradition far more directly concerned with the state whether absolutist or constitutional - a tradition in which Fénelon, with his array of different political constitutions, clearly belongs. When we place Bustān̄’s Tuhfa translation in the context of some of his other works of the time - specifically his manual of bookkeeping ${ }^{640}$ and Nafir Süriyya - we can suggest that the 'anti-political' or 'English' tradition appealed to a Beiruti bourgeoisie rather unconcerned with Ottoman high politics, and tending to concentrate on local civic affairs and above all on the making of money. ${ }^{641}$

Paul et Virginie, although drawing upon (and referencing) Fénelon's narrative, is set, like Crusoe, on a desert island largely beyond the reach of the power of civilised states; its frame of reference is basically individualist, concerned with styles of living and personal relationships. In this it represents, I think, a similar private as opposed to public concern of the Beiruti bourgeoisie at this time: a concern expressed in more directly local terms in Khalīl al-Khūrī’s Way, idhan..., and again in Sa'dallah al-Bustān̄̄’s reworked dramatic version of Télémaque - as well as in much of the subsequent 'romance' fiction of Salim alBustānī and others. ${ }^{642}$ In these works, 'civilisation' tended to become a matter of individual and domestic lifestyle or behaviour, rather than of states or public institutions. Fāris alShidyāq's concern, in $a l-S \bar{a} q$, with private lives and gender relations, as well as much of the

639 'The Peculiarities Of The English', 336.

640 Buțrus al-Bustān̄̄, Kitāb Kashf al-hijāb fì 'ilm al-Hisāb (Beirut: American Press, 1848); Buțus al-Bustān̄̄, Rawdat al-Täjir (The Merchant's Garden) (Beirut: n. s., 1859). A third similar work is also mentioned in Bou Ali, 'Hall of Mirrors', 88.

641 This is not to suggest that Marrāsh was not influenced by these writings. Gaber Asfour has suggested the influence of al-Tuhfa al-Bustāniyya on Ghābat al-Haqq (Ghābat al-Haqq, ed. Asfour, 16), and there are similarities too with The Pilgrim's Progress: the dreaming narrator, and phrases such as 'the Wrath to come' (al-ghadab al-ät $\bar{l})(23 ; 18)$.

642 See Zachs, Making of a Syrian Identity, 72-6; Moosa, The Origins of Modern Arabic Fiction, 157-95. 
'anthropological' interest which the travel-writers brought to European societies in this period, may be seen as belonging to the same tendency. And such a concentration on personal and domestic relations, local civic affairs and commerce, made considerable sense for a bourgeoisie which possessed power and autonomy in just those spheres, while the high politics of state - Ottoman or Egyptian - remained largely beyond it. ${ }^{643}$ It is similarly logical that directly political and constitutional interests, in these decades, should be found above all among those most directly concerned with these high politics: the Ottoman statesmen with their constitutional reforms; Tahtậ̄ī and his protégés translating the Charte constitutionnelle and French law; Khayr al-Dīn with his survey of European constitutions. And we may place Marrāsh, belonging to the Aleppine circle of quasi-independent intellectuals with Ottoman reformist connections, somewhere between the two, with his consideration of tamaddun both in terms of 'state and kingship', of social bonds like 'love', and of the virtues and vices of the 'trial' episode.

Beyond these questions of the general stance of Marrāsh and the Philosopher, we can go on to note more specific congruities. The whole utopian vision of Civilisation, though of course abstract, is applied directly to Syria, and Aleppo, in the final section ('Awakening'); and the story of the ex-slave Yāqūt, an interestingly 'realistic' narrative set within the largely abstract frame of Ghäbat al-Haqq, is based firmly within the Near East: Sudan, Egypt, the Arabcrewed ships of the Mediterranean, Istanbul. An important step on his road away from slavery is attending one of the new institutions of the Tanzimat, a Turkish military school. The opening of the trial of the King of Slavery states that 'you will see that the very majesty of the Prince of Egypt will announce an order to ban the taking of slaves from the depths of

643 Comparable perhaps to the inward-turning and concentration on domesticity in evidence among late nineteenth-century Bengali bhadralok, in Sarkar, Writing Social History, 22-3 and Ch. 8; or the turn to 'personal relations' within the English novel: Williams, The English Novel from Dickens to Lawrence (although both these instances, unlike the Beiruti one, refer to temporal phases, 'turns' in this direction at a point in history). 
Africa', ${ }^{644}$ according to what is decreed by his suzerain, 'His Majesty the great, powerful and mighty Ottoman Sultan Abd al-Aziz Khan, may his rule last for ever. ${ }^{945}$

Again, after listing the series of ancient nations destroyed by specific vices (up to the Greeks

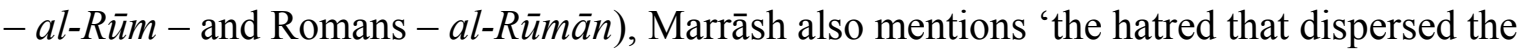
tribes of Lebanon and shook the pillars of Damascus' (al-baghḍ alladhī shattata shumal Lubnān wa-za'za'a arkān Dimashq) ${ }^{646}$ This could of course refer to some earlier event, but it seems likely that the allusion is to the 'events' of 1860-61. At the end of 'Statecraft and Kingdom', when the Captain of the Army of Civilisation despairs of the inhabitants of the Kingdom of Slavery attaining civilisation in less than a thousand years, he gives the following reasons:

For they are a people (sha $b$ ) made up of every tribe (qabila) and nation (milla) under the sky; each of their factions ( hizb) hates the other and strives to destroy and annihilate it; for Love cannot be founded upon a difference of races ( $i k h t i l a \bar{f}$ alajnass), and when love fails, Civilisation is torn apart, for it [Love] is the first basis of it [Civilisation], and when Civilisation departs, the bowels of the homeland are torn apart, and the banners of slavery stream out. ${ }^{647}$

This bitterness is surely traceable to a local context - of strife between Muslims and Christians, elite and commoners. ${ }^{648}$ The uncivilised, superstitious 'customs' denounced in the Third Pillar of Civilisation, too, were presumably actual practices in Syria. ${ }^{649} \mathrm{We}$ have noted $644128 ; 105$.

$$
\text { وسوف ترى ان نفس حضرة قيل مصر سييرز امرأ بابطال اقتناص العبيد من اعماق افريقيا }
$$

$645128 ; 105$.

$$
\text { جلالة السلطان العثماني الاعظم ذي الثوكة والاقتدار عبد العزيز خان ـ دام ملكه مدى الدوران }
$$

It is unclear whether this refers to a specific decree. Abd al-Majid had issued firmans in 1854 and 1857 banning the white and the black slave trade - according to Wielandt little-respected - and Abd al-Aziz was to guarantee the freedom of person of all Ottoman subjects in the 1876 Constitution: Wielandt, 'Marrâsh Und Die Aufklärung,' 137 n. 52.

$64686 ; 70$.

647 69-70; 56.

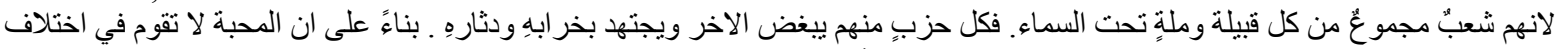

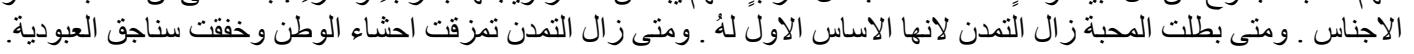

648 And perhaps also between different Christians: Marrāsh's family had been involved in an episode of violence between Greek Catholics and Greek Orthodox earlier in the century: al-Shar', Fransīs Fathallāh Marrāsh, 8.

649 Mishaqa, indeed, had attempted a reasoned disproof of such superstitions in his paper in Bustānī, A 'māl alJam ìya al-Süriyya, 1:50-58. 
the use of the phrase 'love of country free from religious prejudices': it was a theme to which Marrāsh was to return, for instance in an 1870 article on 'al-Wațan', where he denounces 'sectarian chauvinism' (al-ta 'așșb al-madhhabī) ${ }^{650}$ In Ghābat al-Haqq, the context in which it occurs is again reminiscent of Bustānī. Yāqūt is driven to attend his Turkish school because was because he heard 'all the Franks who happened to meet our ship or one of its sailors' (jamī' al-Ifranj alladīna kānū yușādifün markabanā aw aḥad mallāḥīhi) 'cursing the Arab race and despising it' (shatīmat al-jins al- 'Arabī wa-ihtiqārahu). ${ }^{651}$ It is the Arabs' own ignorance, Yāqūt thinks, that is the cause of this:

If [this race] had schools like them, and aids to the advancement of knowledge and a love of country free from religious prejudices, it would not have become a laughingstock among them [the Franks], but would perhaps be more advanced in learning than the entire world, on account of the force of its natural intelligence and energy. And the West does not deny the Arabs' precedence to it. ${ }^{652}$

The coupling of a sense of inferiority before the foreigner and the need for an Arab resurgence is familiar from Nafir Süriyyā; and the programme of schools that promote a nonsectarian patriotism reminds us of Bustānī’s Madrasa Wațaniyya. It is worth noting, incidentally, that despite the vigorous Arab pride of this passage, Yāqūt's own route to an education is still through a Turkish military school: as Bārūt has stressed for the Aleppines and Abu-Manneh for Bustānī, Arabism does not, in the 1860s, imply anti-Ottomanism. We can also find echoes also of Bustān̄’s (and others') suspicions of foreign designs to rule Syria (one of the reasons behind their Ottomanism): when the Philosopher decrees that he who exercises siyāsa must be educated, he gives as one reason that if he is ignorant, he may then be forced to seek guidance from foreigners or put them in charge, and they may

650 Al-Zahrā', 1870, 186-7; reproduced in al-Hulw, al-Fikr al-Lībrālī, 262-4.

$651138 ; 112-3$.

$652138 ; 113$.

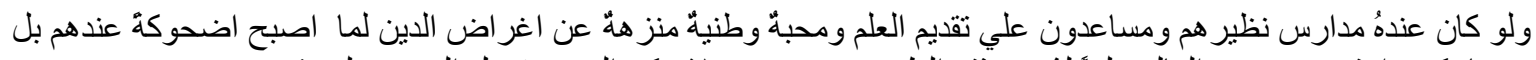

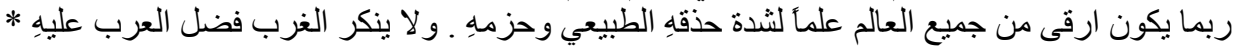

'Precedence' $(f a d l)$ probably refers to the fact that the West had acquired much of its learning from the Arabs, who therefore preceded it temporally. 
misguide him or betray him for the sake of personal interests of their own. ${ }^{653}$

The State of Civilisation conquering that of Slavery could be read in various ways - with reference to the American Civil War, for instance, a war of Abolitionists against slaveholders - but the local allusions seem reasonably clear. As Bruce Masters has convincingly argued, the suppression of the 1850 'events' (with great force) by the Ottoman state paved the way for a reassertion of Ottoman control over Aleppo province, simultaneous with the introduction of the Tanzimat reforms. ${ }^{654}$ This implied a transformation from, in Gramscian terms, a 'moment of force' or actual military repression to a 'moment of consent', or the building of a new, more consensual order (see Chapter 1, pp. 52, 60). The similarity to Marrāsh's account of the State of Civilisation winning its war, and then imposing the 'law of Civilisation' upon the conquered - while leaving them (the Vices) a certain subdued scope within the new order - is suggestive. One of the things the reassertion of Ottoman control allowed was a land-reclamation scheme coupled with 'pacification' of the Bedouin; the reference to the 'tide of greenness' overwhelming the desert around Aleppo, in 'Awakening', could be construed as a reference to this. American and other examples are in the background, to be sure, but it seems clear that this is principally a utopia to be instituted by the Ottoman state, reimposing its control over Syria much more effectively than previously, after the military repression of 1850 and 1860-1. It was to be advised (hopefully) by intellectuals like the Philosopher or members of Marrāsh's circle, and to carry out reforms in the 'Spirit of the Age': encourage trade and agriculture, civic reform, public health, opening careers to the talents, and abolishing manifestations of 'barbarism'. It was to remain nonantagonistic, though perhaps no more, towards religion (the City of the Spirit: the clergy); Ottoman institutions (such as the military schools) and enlightened acts (such as the freeing

$65372 ; 58$.

$$
\text { ويعود حينئذٍ ملتزمأ الى الارشتاد من الاجانب او تحكيمهم ومه ربما يضلونهُ او يخونونهُ لاغر اض ذاتيةٍ لِهم. }
$$

654 Masters, 'Political Economy of Aleppo'; 1864 also saw the reorganisation of Bilād al-Shām into two provinces (Aleppo and Damascus) rather than the previous four. 
of slaves) are specifically endorsed. ${ }^{655}$

\section{Discontents: Barbarous Civilisation}

But this is perhaps to give too unitary and settled a picture of Marrāsh's vision. A good deal of Ghäbat al-Haqq - probably the majority - can certainly be assimilated to this image of enlightened bourgeois civilisation and progress. But there are other elements which seem to sit ill at ease with it, or to push beyond it - and, confused and inchoate though much of this may be, it cannot all be dismissed with a reference to Marrāsh's inconsistencies. Certain of the contradictions in Ghäbat al-Haqq may be seen, in fact, to be prophetic: faultlines waiting to widen into rifts later in the century (including within Marrāsh's own later writing). ${ }^{656} \mathrm{We}$ have already noticed the ambiguity, if not the open contradiction, of Marrāsh's statements on religion and materialism; and though Marrāsh was to adopt, if anything, a more orthodox position with time (in Shahädat al-tabì $a$ ), others were to take up the other side of the debate: in the Darwinism controversy above all, we see the two sides of Marrāsh's quasipantheistic, quasi-materialistic natural theology split apart (the turn of the century was to see, also, a far more open anti-clericalism). ${ }^{657}$ There is also the sheer vehemence of his attack on slavery in the name of freedom. But there are other elements in Ghābat al-Haqq, and still more so in Marrāsh's later writings, that stand out as more difficult to reconcile with the

$655 \mathrm{It}$ is interesting to compare this to the views of Ottoman administrators outlined in Ussama Makdisi, 'Ottoman Orientalism', The American Historical Review 107, no. 3 (2002): 768-96. It might be suggested, however, that 'Orientalism' is in both the Ottoman and Arab cases something of a misnomer: similar attitudes to Western 'Orientalism' were of course displayed, but among Nahda intellectuals at least the repudiation of 'Easternness' was rare: rather, they represented a 'civilised' as opposed to 'uncivilised' East. Indeed, 'Orientalistm' may be usefully seen as a specific version of a wider opposition between 'civilisation' and 'barbarism', which could be applied by Easterners against other Easterners, and by Westerners against other Westerners (e.g. lowland Scots against Highlanders, or South American gentlemen against 'Indians'): see e.g. Kiernan, The Lords of Human Kind, 286-7.

656 To use the metaphor Terence Cave borrows from the 'New Historicists': 'Locating the Early Modern', Paragraph 29, no. 1 (March 2006): 13; see also his Pré-Histoires.

657 Khuri-Makdisi, The Eastern Mediterranean and the Making of Global Radicalism. 
comfortable bourgeois view of society we have seen, for instance, in Khūrī: the repudiation of French-revolutionary or 'utopian socialist' optimism; the celebration of an impersonal, mechanical rationality, and of the quietness of the poor under conditions of harsh inequality.

Thus Marrāsh's account of the trial of Avarice contains a denunciation of the profit-making mentality. Avarice, says the Philosopher, resolves to get children as servants, and accustom them to a meagre diet (bread, cheese and za tar) and hard labour:

And in this way I will be able to gather together all the property in the world. Because a dirham plus a dirham is two dirhams. And two plus two is four dirhams. And four times four is sixteen dirhams. And $16 \times 16=256$ and $256 \times 256=65536$. And so they increase from multiplicand to multiplier until they reach the highest total, where no number is and no pen runs. ${ }^{658}$

This might, in isolation, be read as going entirely counter to the emphasis we find in Bustānī, for instance, on the accountant's mentality (profits and losses) as a suitable way of registering human lives; or more widely - and in Marrāsh himself - the notion that trade and business are integral parts of Civilisation. But this impression would be misleading, as we see when we examine the terms in which this denunciation is framed. Besides this inhuman money-multiplying, it is true, Avarice is accused of inhumanity to the poor, a refusal to give charity. ${ }^{659}$ But Avarice first appears in the Trial as 'gripping with his hands the arm of the wheel of commerce and the support of livelihood'. ${ }^{660}$ And as he grows through multiplication, he thinks:

See! I am resolved to possess the entire world, stop all the wheels of business and make the people my slaves! ${ }^{661}$

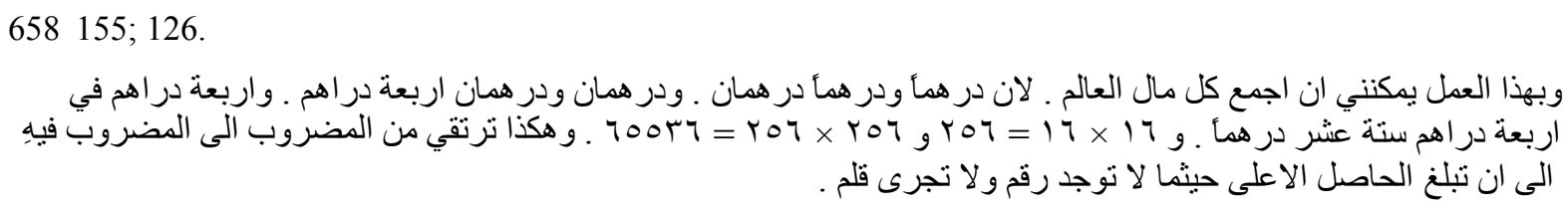


He is compared to the moon, thinking it can stop the rotation of the earth, with time, by its gravity; similarly:

You think that you will stop the movement of business by attracting all property from the hands of the people, and eventually you alone will have power and wealth. ${ }^{62}$

The attack here is then principally on monopoly, in the name of the free circulation of trade; and on a form of 'enslavement', as opposed to, presumably, 'free' capitalist labour. These images of free circulation, as opposed to blocks and obstructions, are found in Marrāsh's Dalīl al-hurriyya, which argues for the freeing up of capital, as opposed to tying it up in gold and jewellery; and Nașrallāh Dallāl argued along similar lines in an 1870 article: money must circulate freely in society, like blood in the human body (with analogies from medicine) ${ }^{663}$

This can plausibly be seen as a free-trade ideology, likely to appeal to the mainly commercial, mainly small-to-medium-sized bourgeoisie of Syria: take away impediments, restrictions and monopolies, and trade will naturally tend to increase the good of mankind. ${ }^{664}$ Marrāsh, in Ghābat al-Haqq, remains largely within these terms, but then also goes beyond them when he suggests that the profit motive itself, if unchecked, will itself lead to monopoly and the stoppage of free circulation. It therefore requires an external authority -

$662155 ; 126-7$.

* تخال انت ايضأ انك ستوقف حركة الاشغال بجذبك كل الامو ال من ايدى الناس وتعود منفرداً بالسطوة والغنا بعد العمر الطويل

663 Nasrallāh Efendi Abdallāh Dallāl, 'al-Māl wa-l-A ‘māl (Property and Labour)', al-Jinān, August 1870; Marrāsh's version of this in Dalīl al-hurriyya was also bound up with arguments against luxury (reminiscent of Fénelon among other Enlightenment writers): see 'Alī al-Shar', 'al-Fikr al-Ijtimā'ī fī Kitābāt al-Marrāsh', in Fransīs Fatḥallāh Marrāsh Rā idan Nahḍawiyyan wa-Tanwīriyyan Baynanā, ed. Bārūt and al-Ṣāliḥ, 177; see also the same complaint about capital hoarding in Syria in 1859 from Lewis Farley, then clerk of the Ottoman Bank at Beirut: cited in Hanssen, Fin de Siècle Beirut, 37-8. The analogy between circulation of trade and of the blood can be found in Adam Smith, Wealth of Nations (orig. 1776), Book 4, Ch. 7, 'Of Colonies', http://www.econlib.org/library/Smith/smWN17.html.

664 Compare, for instance, David Ricardo, Principles of Political Economy and Taxation (orig. 1817), Ch. 7, 'On Foreign Trade', http://www.econlib.org/library/Ricardo/ricP2a.html: 'Under a system of perfectly free commerce, each country naturally devotes its capital and labour to such employments as are most beneficial to each. [...] it distributes labour most effectively and most economically: while, by increasing the general mass of productions, it diffuses general benefit, and binds together by one common tie of interest and intercourse, the universal society of nations throughout the civilised world.' 
the Philosopher, in the name of the state of Civilisation, subordinating Avarice to Generosity - to keep it in its proper place. These passages are thus not quite the expression of a simply 'organic' relationship (Bārūt's term) to the commercial bourgeoisie. And there are suggestions that go even beyond the notion of a paternal regulating state. The initial indictment of Avarice begins with the description of a 'great rebellion': from noise, curses and insults,

It dawned on me that a great rebellion was rising in the world - yes, a great rebellion starting to break out [....] See, the inhabited world has risen against you, o evil spirit, Captain of Avarice and Greed, and see, all people hurl curses and insults at you $[\ldots . .]^{665}$

The indictment concludes:

So the world is not to be blamed, therefore, if it raised rebellions (fitan) against you, Captain of Avarice, [if] its voices are raised against you and its forces rush to slay you - because you are the plain enemy of it and all its interests $[\ldots . .]^{666}$

Here, then - although the Philosopher in the name of the state, 'from above', finally condemns Avarice (by subordinating it to Generosity), an entirely different agency, of an angry crowd, is at work, and is not condemned (though also not endorsed) by the voice of Philosophy. There are no clear indications of what actual 'rebellions' or revolutions Marrāsh may have had in mind; but neither Syria nor Europe were especially lacking in possible examples, from the Lebanese harakāt of the 1840s to the 1858 Kisrawān rebellion of Tanyūs Shāhīn; from the barricades of Paris in 1848 to the Chartists. Certainly Marrāsh gives us no licence to claim him as in any firm sense a socialist or revolutionary, but we are clearly in a somewhat different place to Khūrî̀s anxious repudiation of all 'harakāt'.

$665152-3 ; 124-5$.

$$
\begin{aligned}
& \text { ها قد بداء يلوح لي ان فتنة كبرى تثور في العالم. نعم فتنتة"كبرى آخذة في الثوران . [...] ها قد نهضت المسكونة عليك يا ايها الروح }
\end{aligned}
$$

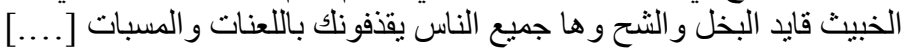

$666156 ; 127$

فلا يُعتب العالم اذن اذا اثار عليك الفتن يا قايد البخل وارتفعت اصو اتهُ ضدك وتبادرت قو اتهُ الى الفتك بك لانك العدو المبين لهُولكل 
Marrāsh's treatment of 'equality', too - for all its apparent casualness, referred to by

Wielandt - contained the seed of something more radical. 'The little men and the poor' (alsighār wa-l-fuqarā') are as necessary to society (perhaps more so) than 'the great and rich' (al- 'uzama $\bar{a}^{\prime} w a-l$-aghniy $\bar{a}$ ). ${ }^{667}$ The latter must recognise the importance of the former, and thus avoid 'the rising of the ninety-nine and the exceeding of the social contract' (wuthūb altis 'a wa-l-tis 'in wa-fart 'aqd al-jam 'iyya), ${ }^{668}$

And why do the voices of the rich have a right to ring out in the palaces of statecraft, and the voices of the rest of the people have not this right? They are the greater and more important part; upon them the power of kingdoms and the forces of kings are founded; upon them the axis of policies is based. ${ }^{669}$

This understanding of the poor not only as objects of charity, or dangerous riff-raff (though both of these are present), but also as the basis of the power and prosperity of the rich, goes beyond anything found in Nafìr Süriyya, as does this suggestion that the poor should participate in their own right in politics (though the means of this participation are left unclear). ${ }^{670}$ It is true that Marrāsh refers, elsewhere in Ghäbat al-Haqq, to the need for the one who exercises siyāsa to be 'a man of noble and wealthy origin' (rajulan min aṣl karìm wa-mūsir), since he will then have the 'good and sound education' (tarbiya hasana wașāliha ) needed in a ruler. ${ }^{671}$ But as 'Alī al-Shar' has shown, in his excellent article in the Ifpo-Aleppo volume, this was only one of the positions in social thinking that Marrāsh was to pass through. Al-Shar' traces his development, first, from his earlier concern (in Dalīl alhurriyya) with only the Aleppine Christian community to a broader view of society in Ghäbat al-Haqq. This is based, as he says, on what is basically a class (rather than a communitarian) conception of social divisions - the rich and poor, great and small - and

$66774 ; 60$.

$66875 ; 60$

$66975 ; 61$.

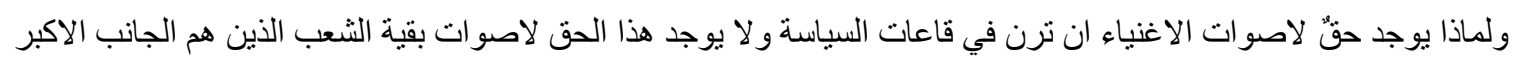

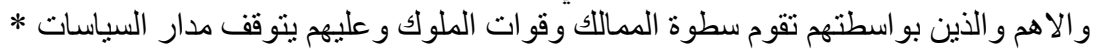

670 Wielandt, 'Marrâsh Und Die Aufklärung', 143-4 appears to read așwāt as referring to votes and thus the electoral franchise, but I think the vaguer sense of 'voices' more likely. $67172 ; 58$. 
may plausibly be related to a growing consciousness of common class interests among the Syrian bourgeoisie, overriding sectarian divisions. A similar division is expressed in a newspaper article of 1870. Here Marrāsh outlines three components of human society: the high, low, and middle. The higher class depends on the other two for the necessaries of life: they are stacked up like columns, 'like a well-built edifice' (mithl haykal jamīl al-bunyān). The upper class is defined by knowledge as well as wealth: property is, or ought to be, the result of cultivation (tahdhīb) and letters or manners ( $\bar{a} d \bar{a} b)$. If anyone without these gets property, he belongs in truth to the lower class - hence this 'stone' must be removed from the edifice and returned to the foundation (the lower class). ${ }^{672}$

This is still a hierarchical view of society; although as in Ghäbat al-Haqq the lower classes are necessary to support the upper, and we now have (what was not present in Ghäbat alHaqq) a third, middle class. Moreover, there is an interesting tension between a hierarchy of wealth and one of education: the two do not always match (as his earlier statement in Ghäbat al-Haqq about the 'man of noble and wealthy origin' would suggest). But in an article from the very end of his life (1873), Marrāsh takes issue with just this hierarchical structure in a far more radical way. All men, rich or poor, are equal in nature, he now says; but the 'barbarism of civilisation' (tawaḥhush al-tamaddun), with its greed, envy, pride and love of dominion has corrupted human nature. ${ }^{673}$ The major standard for judging people's worth is the work they perform: other standards (and Marrāsh had previously suggested largely education and refinement, which went along with wealth and nobility) are false. And from here he proceeds to a radical inversion of the traditional notion of the $a$ c $y \bar{a} n-$ the notables or leaders, as opposed to the common people. Playing on the other meaning of 'ayn as 'source', he now states that the workers are the a' $y \bar{a} n$ - the 'sources' of the prosperity of

672 'al-' Ālam al-basharī’, in al-Zahrā' 1870, p. 157, cited in al-Shar', Fransīs Fathallāh Marrāsh, 170-1. 673 Al-Shar' points to a similar notion in Mir'àt al-ḥasanā, 238: Ibid., 173. 
societies. Worth for them comes from work, whereas the rich have acquired their property by inheritance and by commercial subterfuge, a legal form of theft. Nor will the poor, Marrāsh now suggests, obtain their rights simply by asking for them. ${ }^{674}$

The values are altered, but the earlier insight - that wealth and power depend on the poor and powerless - is still present in the new version of the $a^{\prime} y \bar{a} n$. The comment about the 'barbarism of civilisation' points to another, perhaps more radical reversal: in Ghäbat alHaqq Marrāsh he had seen the laws of civilisation as inscribed in natural man, corrupted by 'the revolutions of conditions and ages' (taqallubāt al-aḥwāl wa-l-ajyāl), but waiting to be restored by civilisation and 'the Cultivation of Reason' ${ }^{675}$ In his last years, it seems, he came to a more pessimistic view of the power of any civilisation to corrupt, that begins to recall more forcefully the radical strands of the Enlightenment - Rousseau, Volney, Paine - as well, perhaps, as the views of Fourier denounced by Khalīl al-Khūrī. The reversal is found, earlier, in an 1870 al-Jinān article, entitled 'Barbarous civilisation' ('al-Tamaddun almutawaḥhish'): this was written against the background of the Franco-Prussian War, reported heavily in al-Jinān at the time, which offered the spectacle of two great 'civilised' nations of Europe destroying each other. ${ }^{676}$ It culminates:

Woe to the civilisation which has led humanity - while at the very summit of perfection - to create the worst of hellish instruments to kill and murder itself! And woe to the civilisation, which, while it calls with the trumpet of joy, glad tidings and song, multitudes of widows and orphans and the poor clamour around it! ${ }^{677}$

So much, it would seem, for the civilisation of Europe, which Marrāsh had admired to the point of adulation in Riḥlat Bārīs. The distance from Khūrī's admiration of England's

674 'al-A 'yān' in al-Jinān 1873 (15 February 1873): 119-22; Ibid., 171-4.

$67580 ; 65$.

676 See also the article 'al-Harb wa-l-tamaddun' by Hanīn Ni 'matallāh al-Khūrī, translator of Guizot's History of Civilisation in Europe: al-Jinān, 1870, 462-463; 504.

677 'Al-Tamaddun al-mutawaḥḥish', al-Jinān 1870 (December), 633.

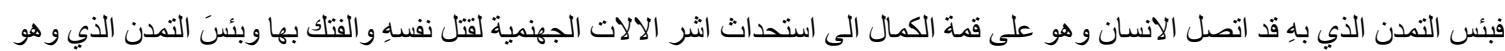

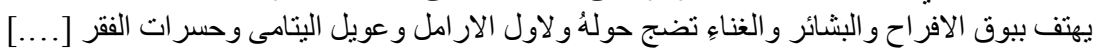


stability despite the flagrant gap between rich and poor should be obvious. Bārūt, additionally, cites an 1871 article, where Marrāsh apparently reverses his opinion of the Ottoman version of civilisation: the Tanzimat were nothing but 'a king of barbarism, who has put on the dress of civilisation'. ${ }^{678}$ The crucial point here is that disorder and contradiction are now seen, not between a harmonious civilisation and a 'barbarism' or 'slavery' external to it, but within the body of civilisation itself.

In these later articles, then, and in their foreshadowing in Ghäbat al-Haqq, Marrāsh can be seen as a predecessor - an incomplete one, to be sure - of the later 'radicalism' of the turn of the century; ${ }^{679}$ and Hourani may not have been so wrong in putting him out of chronological order under the title of 'Christian Secularists', with Shiblī al-Shumayyil and Farah Anțūn. ${ }^{680}$ But perhaps the quality by which Marrāsh stands out most among Arabic writers of his time is his tone, or style. There is a visionary urgency in his writing - visible in the last quotation, but also in many of the passages cited above - which the next generation of Arab literati certainly noted ${ }^{681}$ Something of this tone is already present in his Khutba fi ta ziyat almakrūb (1861), as is noted by al-Shar': he sees it as a genuinely new element in Arabic prose, though with precedents in existing Christian literature, and attributes it, with some reason, to the difficulty of an intellectual in a non-intellectual milieu, incapable of influencing the society around him. ${ }^{682}$

It is difficult, in fact, to separate out different elements: personal temperament, the later isolating effects of blindness, and his social situation. But one element of this combined situation is clear: Marrāsh - despite his supports in the 'Aleppo Circle', was isolated and

678 'Siyāhat al-'aql', al-Jinān 8 (15 April 1871), 69; cited in Bārūt, Harakat al-Tanwīr al- 'Arabī, 14 n. 7. 679 Khuri-Makdisi, The Eastern Mediterranean and the Making of Global Radicalism.

680 Arabic Thought in the Liberal Age, 1798-1939, Ch. X.

681 See, for instance, al-Humșī, Udabä’ Halab, 26.

682 Fransīs Fathallāh Marrāsh, 54-6. For some precedents in the Protestant missionary literature and Bustānī, see Hill, 'Early Arabic Translations'; and passages cited in Makdisi, Artillery of Heaven. 
alone, as compared with men like Bustānī, Ṭahțāwī and Khūrī. He was not, like them, an active educator or bureaucrat, manager of a newspaper or printing enterprise. He was, to be sure, during the years of the composition of Ghäbat al-Haqq and briefly afterwards, active as a medical practitioner with Wortabet. But on his return from Paris his blindness made this impossible; and we accordingly see him in his final years - the years of these more radical articles - as above all a writer, although he could not physically write and made insistent demands on his friends to write to his dictation. ${ }^{683} \mathrm{He}$ could hold court to a small circle of acquaintances in Aleppo; but his main - really his only - way of reaching the world beyond that was through his words. Supported by a wealthy family, he did not need to make a living by his pen, as writers of later generations did - this would have been near-impossible in any case under the still largely patronage-dependent conditions of the time. But one can see the urgent, projected voice, already present in his earlier writings, as an index and an element of a process which was to continue as the century went on: the separation of the writer or intellectual from precisely that 'organic' relationship to a class - the largely commercial bourgeoisie of Syria - that we have seen epitomised in the 'Aleppo Circle' and in Beiruti writers like Bustān̄ and Khūrī. The social basis, both of the 'radicalism' described by KhuriMakdisi, and of those later writers with a visionary, urgent style comparable to Marrāsh's Farah Anțūn, or 'Arab Romantics' like Jibrān Khalīl Jibrān and Mīkhā' īl Nu 'ayma - was to be far less in the comfortable merchant bourgeoisie than among an often diasporic 'lowermiddle-class' of professional people and intellectuals. Marrāsh, in anticipating this situation, bears out the supposition of Fredric Jameson: that 'ideology and utopia', the paired terms of Karl Mannheim, are not true opposites, but found together within the consciousness of a class or group, and its literary forms. ${ }^{684}$

683 al-Humșī, Udabā' Halab, 103-4.

684 The Political Unconscious, 290-1: ' [...] all class consciousness of whatever type is Utopian insofar as it expresses the unity of a collectivity [.... but] Utopian not in itself, but only insofar as all such collectivities are themselves figures for the ultimate concrete collective life of an achieved Utopian or classless society.' 


\section{Conclusions: Nahda Studies and Material Histories}

There has been a recent revival of interest in the Arab Nahda in the Western academy, of which this study forms a part. A spate of books and articles have appeared on Arabic culture and literature of the nineteenth century, many of which have already made an appearance in this study. In addition to, for instance, Shaden Tageldin's Disarming Words, Nadia Bou Ali’s In the Hall of Mirrors (soon to be published in book form), and Stephen Sheehi's Foundations of Modern Arab Identity, ${ }^{685}$ a special issue of Middle Eastern Literatures on 'Authoring the Nahda' ${ }^{686}$ and a pair of articles by Sheehi and Tageldin in the Journal of Arabic Literature offering a 'Critical Theory' and a 'Critical Pedagogy' of the Nahda,${ }^{67}$ have brought 'the Nahda' into clear focus before the specialist public. In social and cultural history, there has been a similar intensification of interest in the period, which again I have engaged with in the foregoing: Jens Hanssen's Fin-de-Siècle Beirut, Khaled Fahmy's All the Pasha's Men, Ilham Khuri-Makdisi's The Eastern Mediterranean and the Making of Global Radicalism, Ussama Makdisi's Culture of Sectarianism, are some of the fruits of this. And they take their place, perhaps, within a renewed interest in the 'late Ottoman' period beyond the Arab provinces. At the same time, there has been, it seems, an intensification of what is of course a much older interest in the period, in Arabic-language writing: 'Alī al-Shar's and Karam al-Hulw’s recent studies of Marrāsh, ${ }^{688}$ the substantial proceedings of a conference on

685 Others with which I have had less occasion to engage here include: Abdulrazzak Patel, The Arab Nahdah: The Making of the Intellectual and Humanist Movement (Edinburgh: Edinburgh University Press, 2013); the collective volume Nadia Al-Bagdadi, Fawwaz Traboulsi, and Barbara Winckler, eds., A Life in Praise of Words: Ahmad Faris al-Shidyaq and the Nineteenth Century, Literaturen Im Kontext. Arabisch Persisch - Türkisch (Wiesbaden: Reichert, 2015).

686 Kamran Rastegar, 'Introduction', Middle Eastern Literatures 16, no. 3 (1 December 2013): 227-31. 687 Stephen Sheehi, 'Towards a Critical Theory of Al-Nahdah: Epistemology, Ideology and Capital', Journal of Arabic Literature 43, no. 2-3 (1 January 2012): 269-98; Shaden M. Tageldin, 'Proxidistant Reading: Toward a Critical Pedagogy of the Nahdah in U.S. Comparative Literary Studies', Journal of Arabic Literature 43, no. 2-3 (1 January 2012): 227-68.

688 al-Shar', Fransīs Fathallāh Marrāsh; al-Hulw, al-Fikr al-Lībrālī; and of course the (still unpublished) Bārūt and al-Ṣāliḥ, eds., Fransīs Fatḥallāh Marrāsh Rā'idan Nahḍawiyyan wa-Tanwīriyyan Baynanā. 
Ṭahtāwīi, ${ }^{689}$ and Fawwāz Ṭarābulsī’s fascinating imaginative reconstruction of the period Harīr wa-hadì $d{ }^{690}$ all belong to the last ten years, while more general studies like Charbel Dagher's, Māhir al-Sharīf's and Bārūt's are not much older. ${ }^{691}$ There has also been a new and very welcome trend of reprinting original 'Nahda' texts in facsimile, by the press of Dār alKutub in Cairo, the Egyptian National Centre for Translation, and others; the online availability of such texts continues to increase; and translations (into English at least) are slowly beginning to appear. ${ }^{692}$

One can see, in other words, why Sheehi can write, in the aforementioned article, of 'Nahda studies' as an emerging field in its own right. In the field of literary and cultural criticism, the nineteenth century is attracting attention for its own sake, rather than being dismissed or hastily dealt with as prelude to the twentieth century; and the term 'Nahda' seems to have become fixed as the accepted general descriptor for the cultural movement of the period - a trend which goes back, I think, to Jurjī Zaydān's 'al-Nahḍa al-akhīra' ('the recent awakening') in $1914^{693}$ - and which I follow in this study.

In many ways all of this is most welcome, and it is good to be engaged in a visibly growing area of scholarship. At the same time, however, the hardening into 'the Nahda', or 'Nahda

689 Rifā 'a al-Tahṭāwī, Rā 'id al-Tanwīr, Silsilat Abhāth al-Mu’tamarāt 16 (Cairo: al-Majlis al-A ' lā li-l-thaqāfa, 2007).

690 Fawwāz Ṭarābulsī, Harīr wa-ḥad̄̄d, Min Jabal Lubnān ilā Qanāt al-Suways (Beirut: Riyāḍ al-Rayyis, 2013).

691 Charbel Dagher, al- 'Arabiyya wa-l-tamaddun, fì Ishtibāh al- 'alāqa Bayn al-Nahḍ wa-l-Muthāqafa wa-lhadātha (The Arabic Language and civilisation: The Ambiguous Relationship Between Nahda, Cultural Exchange and Modernity) (Beirut: Dār al-Nahār, 2002); Sharīf, Rihānāt al-Nahḍa; Bārūt, Harakat alTanwīr al- 'Arabī; see also, for a Franco-Lebanese collaboration, Père Karam Rizk and Dominique Avon, eds., La Nahda : Réveils de La Pensée En Langue Arabe. Approches. Perspectives (Colloque Organisé à l'USEK Les 28-29 Octobre 2004) (Kaslik: Presses de l'Université Saint-Esprit de Kaslik, 2009).

692 Newman's translation of Ṭahțāwī, An Imam in Paris; and Allen's of Muwayliḥ̄, Allen, A Period of Time have probably had a significant role in opening up the 'nahda' to English-speakers; recently we have acquired Humphrey Davies's magnificent translation of Fāris Shidyāq, Leg over Leg, trans. Humphrey Davies, 4 vols., Library of Arabic Literature (New York: NYU Press, 2013); while Jens Hanssen is undertaking a translation of Bustānī's Nafìr Sūriyyā.

693 Zaydān, Tārīkh Ādāb al-Lugha al- 'Arabiyya; Dominique Avon claims that the term was first adopted into English usage by Hamilton Gibb: 'La Nahda au cible de l'orientalisme', in Rizk and Avon, La Nahda: Réveils de La Pensée En Langue Arabe, 199-200. 
studies', brings with it certain risks, in a number of areas. How are we to conceive of this Nahda's location in time, and in space, or intercultural relations? And how are we to relate what remains a phenomenon perceived largely through the lenses of literary and cultural criticism or intellectual history, to the broader social and economic developments of its period? By way of conclusion, I will reflect on what this study and its subject-matter can suggest in seeking possible answers to these questions, in relation to other recent work in the field.

One thing that stands out about the recent work on the Nahda or the 'late Ottoman period' is its persistent orientation towards the future: even when its main subject is the nineteenth century, it tends to look forward to the twentieth century and indeed the present. This sense of the Nahda as the foundation or origin of modernity in the Arab world was present in Zaydān's early use of the term, persisted through many of the mid-twentieth century studies, ${ }^{694}$ and has considerable purchase today. The nineteenth century is still often treated though in greater detail than formerly - as a first, perhaps foundational stage, in studies of largely later phenomena: the Egyptian novel, Arab modernity, and the like. ${ }^{695}$ Even within the 'late Ottoman' period itself, historical studies tend to concentrate on the decades from 1880 to 1914 , even when they reach back into the 1870 s, 1860 s or further. ${ }^{696}$

I have no quarrel with this in itself; and some of the most impressive inquiries into the period (like 'Āmil's) have been attempts at understanding the past in order to answer pressing

694 Out of many, we may cite Antonius, The Arab Awakening; Albert Hourani, The Emergence of the Modern Middle East (Berkeley and Los Angeles: University of California Press, 1981); for literary modernity specifically, see Hafez, The Genesis of Arabic Narrative Discourse; Moosa, The Origins of Modern Arabic Fiction; for the Ottoman Empire and Turkey, see Lewis, The Emergence of Modern Turkey.

695 Selim, The Novel and the Rural Imaginary in Egypt; Tarek El-Ariss, Trials of Arab Modernity: Literary Affects and the New Political (New York: Fordham University Press, 2013); the title of Sheehi, Foundations of Modern Arab Identity, though it concentrates on the Nahda period itself, is also revealing. 696 For instance, Khuri-Makdisi, The Eastern Mediterranean and the Making of Global Radicalism; Hanssen, Fin de Siècle Beirut; Ryzova, Age of the Efendiyya. 
concerns in the present. But I am concerned that too many accounts approach the early and mid-nineteenth century with a view to finding in it foreshadowings of late-nineteenth and twentieth-century phenomena. The creation and military expansion of Mehmed Ali's regime, the rapid growth of Beirut and Mount Lebanon silk production, the Ottoman Tanzimat, are all studied in the knowledge that, to varying extents, they failed: that Egypt was occupied by the British, that the Lebanese silk trade vanished after the First World War, that the Ottoman Empire fell apart and was succeeded, in Bilād al-Shām, by the regime of the Mandates. In the cultural field, too, the style of Ṭahțāwī or Shidyāq or Nāṣîf al-Yāzijī is studied in the knowledge that it was replaced, ultimately, by the modern Arabic novel or short-story or newspaper article. And the knowledge that all this, in fact, happened, can lead to the assumption that it could not have happened in any other way: that all that earlier history was not just determined (as it was) by powerful forces outside the control of the particular historical agents we examine, but was predetermined to end just as it did.

But that is not the way that time, or any historical period, is lived through. It is in an attempt to offset this emphasis, and to explore the range of possibility within this earlier time, that I have concentrated, in this study, on the mid-nineteenth century, between roughly the 1830 s and the mid-1870s, as a distinct period, rather than as a prologue to the events of 1880-1914 or afterwards. It may be seen, in general historical terms, as an interlude between the advent of major contact with the forces then reshaping the world - the capitalist world market, the modern bureaucratic state, modern cultural forms, which had their centre of gravity in Europe or 'the West' - and the final imposition of direct Western imperialism over these lands. Of course the history is uneven: Algeria was directly occupied by Europeans at the start of our period, in 1830, Tunisia in 1881 and Egypt in 1882, while Bilād al-Shām escaped this fate until 1919. But there was a window, varying in length in different territories, when 
under the conditions of a European imperialism still primarily commercial and diplomatic rather than territorial and expansionist, certain 'independent' developments in the ArabOttoman lands appeared to be possible. ${ }^{67}$ Thus the connection between the bourgeois sense of 'civilisation' within these particular decades, and utopian writing and thinking, is more than a casual one. This was a period when 'utopian' possibility took on, for certain dominant groups in these lands, precisely that form: the aspiration to civilisation on a par with, and in similar terms to, the civilisation of bourgeois Europe. Nor (to turn back to the succeeding periods) was this aspiration wholly effaced by their subsequent imbrication in the more rigid conditions of the high-imperialist period. ${ }^{698}$

But as well as the mid-nineteenth-century specificities of the period under study here, there are also its links backwards in history: the continuities with earlier phases of Arab-Ottoman historical and cultural development. I have attempted to highlight these to some degree by insisting on the earlier Arabic presence of tamaddun, of the Mirrors for Princes genre, of Khaldūnian thinking, and the extent to which Nahda writers were drawing on these; ${ }^{699}$ or, in another area, on the Ottoman (as opposed to Egyptian-national) nature of Mehmed Ali's polity. But many of the precise links, of continuity or change, between the middle decades of the nineteenth century and what preceded them, remain to be drawn; and this is largely due to the lack of attention that has been given, in all areas, to the centuries between the Arab 'Golden Age' and the 'modern' period, which are now slowly beginning to be reclaimed from their reputation as the age of 'decadence' (itself the necessary counterpart to the notion of 'Nahụa', revival). This is an area which remains - despite the impressive work now being

697 See James McDougall, 'A World No Longer Shared: Losing the Droit de Cité in Nineteenth-Century Algiers' (unpublished manuscript, n.d.) for the extremely ephemeral character of this 'window' in Algeria. 698 For certain general distinctions between the two eras ('Age of Capital' and 'Age of Imperialism'), which, though Eurocentric, are partially applicable to the Arab-Ottoman lands, see Hobsbawm, The Age of Capital, $354-8$.

699 For another instance, the persistence of the maqāma form, and arguments against the teleology of modernity in a literary context, see Mohamed-Salah Omri, 'Local Narrative Form and Constructions of the Arabic Novel', Novel: A Forum on Fiction 41, no. 2-3 (Spring/Summer 2008): 244-63. 
done $^{700}-$ to be developed.

There is then the question of the Nahda's spatial or intercultural connections, within its own period. The Nahda has always been seen as an Arab phenomenon, and legitimately so: it is by definition the Arab, or Arabic-language, awakening or revival. But the insistence on its Arabness, or on the interaction between the Arabs and Europe, can lead us to overlook two other factors. First the variation within the 'Arab world': what is offered as an account of Arab history as a whole often turns out, on closer inspection, to be a study of only Egyptian or Levantine developments. It is with this in mind that I must disclaim, for this study, any validity beyond the specific centres it examines: Egypt (centred on Cairo), Beirut, Aleppo. My conclusions may - and I hope they will - offer suggestions for an examination of other parts of the Arab or Arab-Ottoman world; but they can in no sense substitute for such an examination. If we want to know what was happening in those other places, then rather than generalising about 'Arab history' or 'Arab modernity' from Egyptian or Shāmī instances, we must study - Iraqi, Tunisian, or Algerian history.

Second, there are the movement's other, non-Arab contexts. There is most obviously the fact that a large part of it took place within the Ottoman Empire, or within territories like Egypt and Tunisia which contained a strong Ottoman component. The interactions between the Ottoman reformism of the Tanzimat and the Nahda, long excluded from consideration by both Arab and Turkish nationalist historiographies, are still under-examined, though coming now into greater prominence. ${ }^{701}$ I hope I have given the Ottoman context its due weight in

700 Most notably, in the seventeenth and eighteenth centuries, on the Christians of Bilād al-Shām: the outstanding figure is Bernard Heyberger: for instance, Les Chrétiens Du Proche-Orient; Hindiyya, Mystic and Criminal, 1720-1798: A Political and Religious Crisis in Lebanon, trans. Renée Champion (Cambridge: James Clarke, 2013); But see also the work of the journal Mamluk Studies Review, and especially of Thomas Bauer: e.g. 'Mamluk Literature: Misunderstandings and New Approaches', Mamluk Studies Review 9, no. 2 (2005): 105-32.

701 As notably in Bārūt, Harakat al-Tanwīr al- 'Arabī; for a concise account of the development of Arabiclanguage historiography of the Ottoman period, see Muhammad 'Afĩfi, 'Arab wa- 'Uthmāniyyun: ārā 
this study, though I have been unable to draw directly on works and sources in Turkish and other of the languages of the Empire: that kind of connected or comparative undertaking is, however, beginning to emerge. ${ }^{702}$

Beyond the specifically Ottoman context, there is the question of the global placing of the Nahda. This is still too often reduced to the question of its relationship to (Western) Europe, despite the fascinating recent work on specific interactions between Arabic and non-WesternEuropean 'Enlightenment' movements: Orit Bashkin and Lital Levy on the Nahda and the Jewish haskalah, ${ }^{703}$ or Ioana Feodorov on the Arab-Balkan links of an earlier period. ${ }^{704}$ I have emphasised, in the third chapter of this study, that the expanded horizon of Nahda intellectuals took in not just Europe but the - European-dominated - globe; and that this was in fact crucial to their changing understanding of their own 'place in the world'. If there were some people (largely European) who might be thought of as, at least in some respects, 'above' the urban bourgeois or officials of Egypt and Syria in the scale of civilisation, there were also others (non-Europeans) who could be placed emphatically 'below' them; and this was a crucial way of legitimising their treatment of 'uncivilised' groups within the OttomanArab world itself, or (as in Sudan) at its edges. I have also on occasion sketched in, tentatively, some analogies with other non-European contexts: Indian or Japanese. But a fullscale comparative inquiry into different non-European (and perhaps also European) experiences of capitalist modernity would do far more to shift discussions of the Arab-

Mutaghāyira (Cairo: Dār al-Shurūq, 2005).

702 E.g. Stephan Guth, Brückenschläge: Eine Integrierte »turkoarabische« Romangeschichte (Mitte 19. Bis Mitte 20. Jahrhundert), Literaturen Im Kontext. Arabisch - Persisch - Türkisch (Wiesbaden: Reichert, 2003); Adam Mestyan, "“A Garden With Mellow Fruits Of Refinement” - Music Theatres And Cultural Politics In Cairo And Istanbul, 1867-1892' (Doctoral thesis, Central European University, 2011).

703 Bashkin, 'Why Did Baghdadi Jews Stop Writing to Their Brethren in Mainz?'; Lital Levy, 'Jewish Writers in the Arab East: Literature, History, and the Politics of Enlightenment, 1863-1914' (Doctoral thesis, University of California, 2007); Lital Levy, 'The Nahḍa and the Haskala: A Comparative Reading of "Revival” and "Reform", Middle Eastern Literatures 16, no. 3 (1 December 2013): 300-316.

704 'Circumstances of a Special Relationship: Christian Arabs and Romanians during the 16th-18th Centuries', Chronos. Revue d'Histoire de l'Université de Balamand, 2007, 95; 'Ottoman Authority in the Romanian Principalities as Witnessed by a Christian Arab Traveller of the 17th Century: Paul of Aleppo', Orientalia Lovaniensia Analecta 148 (2006): 295-310. 
Ottoman lands beyond not so much an Arab as a 'Middle-Eastern' or 'Islamic' narrowness, and enable us to see not only the shared but also the genuinely distinctive features of these different contexts. ${ }^{705}$

In one direction, indeed, this kind of debate may be being opened up, as the descriptor 'Nahda' is itself challenged, in much of the recent Arabic-language work, by the alternative term 'tanwīr', Enlightenment. ${ }^{706}$ The term's connotations are less Arabic-specific than 'Nahda', though they hover uneasily between universalism and Eurocentrism. Indeed, much older criticism of the Nahda (Western and Arabic) fell into a pattern of first assuming 'Enlightenment' (or 'the ideas of the French Revolution', or 'liberalism') as a fixed, unitary set of ideas, and then measuring an Arab writer by how far he or she has successfully 'accepted' or 'transmitted' these ideas. Thus, to take an example already discussed, Wielandt (perhaps following Ra'îf Khūrī) frames her article in terms of Marrāsh's status as 'one of the earliest and most engaged transmitters (Vermittler) of the thought (Gedankengut) of the Enlightenment and the French Revolution' for Arab readers. But, she asks, did Marrāsh really understand 'key concepts' like Freedom, Equality, Reason and Civilisation in the same way as 'those who had propagated them in the philosophy of the Enlightenment and the French Revolution'? - and she goes on to locate all those elements which are found in Rousseau, Condorcet, et al. but 'lacking' (fehlen) in Marrāsh. ${ }^{707}$ This manner of proceeding was always insufficient: it failed to recognise the varied and contested character of the European movements and discourses which may be summarised, in a kind of shorthand, as 'Enlightenment'; and it reduced the role of Arab intellectuals to passive reception or transmission, measuring them always by a - somewhat mythical - European standard. ${ }^{708}$

705 A collective work like Pernau et al., Civilizing Emotions: Concepts in Asia and Europe, 1870-1920 may be seen as moving towards this.

706 As in Bārūt, Harakat al-Tanwīr al- 'Arabī; al-Majlis al-A 'lā li-l-thaqāfa, Rifā 'a al-Tahțāwī, Rā' id al-Tanwīr, etc.

707 'Marrâsh Und Die Aufklärung', 118; 136; 139 n. 61.

708 For a critique of this approach in the case of liberalism and Egyptian thought, see Hussein Omar, 'Arabic 
In that sense, the expression 'the Arab Enlightenment' is greatly preferable to notions of the Arab reception or transmission of the (European) Enlightenment. It may still perhaps be in danger of flattening Arab writers' ideas into a kind of false homogeneity (as with overenthusiastic uses of terms like the 'Scottish' or 'French Enlightenment'); or of excluding the interactions of Arab writers with European post-Enlightenment thinking, or their very substantial interactions with earlier Arab intellectual traditions. But it is to be welcomed insofar as it allows us to see the extent to which these writers were genuinely part of an 'Enlightenment' discourse, and the extent to which they were genuine participants in that discourse in their own right: engaging, certainly, with ideas that had come from elsewhere and largely from Western Europe - but working through them and reshaping them according to their own situation and priorities. It is very much in this sense that I have tried to deploy such notions as 'Enlightenment' and 'civilisation' in this study. And I have suggested, for instance, parallels between Marrāsh and Shelley or Leopardi, not as suggestions of influences but as comparisons between writers grappling with and thinking through similar sets of ideas. It remains to be seen whether, and how, a concept like 'Enlightenment' may be extended, comparatively, across a wider range of different non-European formations over the long nineteenth century.

But whether we speak of 'Nahda' or of 'tanwīr', we are still dealing largely with a phenomenon seen through the perspectives of intellectual history, cultural studies, or literary criticism. And perhaps the greatest danger for 'Nahda studies' - greater than its tendency to a teleological orientation towards modernity, or its potential narrowness within the Arab world

Thought in the Liberal Cage', in Beyond Muslim Liberalism, ed. Faisal Devji and Zaheer Kazemi (London: Hurst, 2016); cf. on late Ottoman and Mandate Palestine, Munir Fakher Eldin, 'Communities of Owners: Land Law, Governance, and Politics in Palestine, 1858-1948' (Doctoral thesis, New York University, 2008). 
- is that it will remain confined within a culturalist perspective. It was the perception of this danger that led me, during the writing of this thesis, to preface what was initially planned as a literary and cultural study with an enquiry (Chapter 1) into the socio-economic relations within which those engaged in literary and cultural activity were situated. There are, to be sure, many excellent recent examples of attention to the specific material contexts of literary and cultural production: for instance the work of Elizabeth Holt and Jens Hanssen. But it is, I think, legitimate to question why the tone of much of the emerging 'Nahda studies' field in the Western academy should be dominated by questions of Arab 'identity', 'subjectivity', or a largely culturally-conceived 'modernity' - rather than, for instance, 'capitalism', 'modes of production', 'world-systems', as in some earlier phases of the historiography, namely the interventions of Wallersteinians, dependency theorists, and Arab and Soviet Marxists upon whom I draw - particularly that of Mahdī 'Āmil. It is because the first, culturalist set of questions seemed to me, finally, to be unanswerable in their own terms, that I have attempted to bring back in those earlier, perhaps 'economist', arguments; and to analyse part of the cultural production of the Nahda in relation to what is ultimately a hypothesis about class relations and modes of production, rather than about identities or epistemes.

One particular emphasis, within this 'culturalist' tendency, is worth dealing with in a little detail, as it has been especially influential. This is the concentration on the utter domination of European modes of thinking, or of 'representation' - a Foucauldian pattern of ideas which was most strikingly introduced into studies of the Arab-Ottoman world by Timothy Mitchell's Colonising Egypt (1988). ${ }^{709}$ As its preface states, this is 'not a history of the British colonisation of Egypt but a study of the power to colonise.' Derek Gregory, drawing upon Sami Zubaida's review of Colonising Egypt, has pointed out one limitation of this

709 I draw, in what follows, on criticisms of similar tendencies in South Asian postcolonial scholarship, by Sarkar, Writing Social History, esp. 91. 
approach: that 'it fixes its gaze so firmly on the West that it can only catch glimpses of other human beings through a glass, darkly.' Thus the travellers from Egypt to the International Congress of Orientalists with whom Mitchell begins 'disappear' from his account, and they, or any other Arab or Egyptian voice, 'rarely reappear'. ${ }^{710}$ Like his inspirer Michel Foucault, Mitchell looks at history from the same kind of place as the projectors of grand schemes of colonisation, discipline, and 'enframing'. Those who were the subjects of these schemes do not appear, or only in displaced form - as when he uses an account by Pierre Bourdieu of the Kabyle dwelling as a stand-in for the 'traditional', pre-colonisation organisation of space in Egypt.

I have tried, rather - especially in my third chapter - to focus firmly on the Egyptian and Shāmī voices, and specifically on the gaps between their consciousness and that of the European intellectuals, educators, projectors of schemes of order, whose works Ṭahțāwī and his pupils (for instance) were translating. ${ }^{711}$ Mitchell and those who follow him assume that there was a tendency towards the ultimate identity of these two kinds of consciousness: as the 'power to colonise' did its work, Arab and Ottoman minds were becoming effectively colonised by European ideas, or orders of representation. This oddly reproduces the older assumption of the simple transmission of European ideas into Arab minds, that we have seen in Wielandt's account of Marrāsh, while inverting its values: for Wielandt (and a host of earlier studies) 'modernisation' was presumed to be good; for Mitchell it is Western-imposed 'mischief'; but their notation of its processes and effects seems to be largely the same. I have tried to present some of the evidence on the other side of the question. Thus Tahțāwì's reshaping of various European works into a geography of Mehmed Ali's domains, in al-

710 Geographical Imaginations (Cambridge, MA and Oxford: Blackwell, 1994), 180; Sami Zubaida, 'Exhibitions of Power', Economy and Society 19, no. 3 (1990): 359-75.

$711 \mathrm{Cf}$. Khaled Fahmy's excellent attempt to show the scope for resistance, confusion, mistranslation, etc. of grand schemes of order, within the middle and lower ranks of Mehmed Ali's army: All the Pasha's Men, esp. 30-32. 
Ta 'rībāt al-shāfiya, his reworking of Malte-Brun's words on Islam and Syria, his blending of the European distinction between civilisation and barbarism and the Khaldūnian one between settled and nomadic life, offer alternative ways of understanding the relationship between European and Arab-Ottoman consciousness (even elite consciousness) in the Nahda period. They suggest that the process of adoption and adaptation of knowledge and of literary and cultural forms from Europe was creative and complex: that these were reshaped by interaction with local knowledge, priorities, and cultural forms. ${ }^{712}$

It is odd, then, to find many of these points being made, about literary translation from European languages into Arabic, by Shaden Tageldin in Disarming Words - but then being used to draw a conclusion very close to that of Mitchell: that the nineteenth and early twentieth centuries were a time when Arab writers were drawn in a state of almost total intellectual subjection to Europe. Tageldin modifies Mitchell's thesis, seeing 'cultural imperialism as a dynamic of translational seduction rather than unilateral imposition'. ${ }^{713}$ The complex ways in which European ideas and texts were rewritten into Arabic provide most of the matter of her book. Yet she finally reveals these modifications as Arabic disguises for what remain essentially European notions. Translation was 'seduction,' a process that encouraged Egyptians to aid enthusiastically the extension of Western power, by inducing them to see themselves as equal or even superior to Westerners. Thus European or Western imperialists do not simply recreate the world in their own image (as Marx and Engels said of the bourgeoisie), but induce the colonised into wanting to recreate themselves in the image of Europe, so that the latter will do the job for them. But it is a "delusory "mirror image" of themselves that they have caught, and admired, in the gleam of the colonizer's I'. ${ }^{714}$ The difficulty of this reflection metaphor is that it assumes that European ideas and forms, though 
Arabised, remained essentially European: hence the delusion involved in the colonised believing that they had seen themselves in the 'mirror image'. This is not to say that European-derived elements were anything less than crucial to the cultural phenomena under discussion; but it is to question whether, say, the adoption of European notions of 'order' in Mehmed Ali’s army or schools (including Țahțāwī's textbooks), was an event for which the impetus and agency can be located ultimately in Europe. What the examples presented in this study seem rather to show is the extent to which such forms of adoption were deliberate acts motivated by local agency and priorities: those of Mehmed Ali's dynasty, or of Arabicspeaking intellectuals like Ṭahțāwī within it.

In other words, I would accept much of the detailed argument of Tageldin's study - as well as many suggestive points from Mitchell - but reject the overall characterisation of the cultural dynamic of the Nahda as one of dependence alone. I have sought to show instead the scope that did exist for 'independent' agency on the part of members - to be sure, elite members - of Arab-Ottoman societies themselves. But what I do not wish to do, in emphasising this agency, is to slide back, from a Foucauldian sense of the utterly overwhelming determinations of power, into notions of the cultural, the aesthetic, or individual experience, as a privileged area outside the determinations of 'material' histories. This, it seems to me, is the danger of the emphasis found in a recent study which offers to work between the Nahda period and contemporary Arab culture: Tarek El-Ariss's Trials of Arab Modernity: Literary Affects and the New Political. In setting out his stance towards the Nahda, El-Ariss takes issue with Hourani, who 'argues that the Nahda [...] arises from the violent shock embodied in the French invasion of Egypt in 1798' - the classic if now rather outmoded focus on Napoleon, which Peter Gran, notably, earlier criticised. But El-Ariss is attacking, more than the focus on that particular year and event, the fact that 'violence $[\ldots]$ is 
often described and studied in colonial and military terms [...].' Instead, 'It is important to investigate literary staging of personal struggle, collapse, disorientation and crisis...' So: 'The experience of Arabic travellers and writers in European cities and towns, forced to endure different weather and food, and learn new languages and customs, are key for identifying multiple sites of the modern. ${ }^{715}$

Thus, from a violent military encounter, doubtless overemphasised but nonetheless understood in the terms of material ('colonial and military') history, El-Ariss has refocussed the whole question of the Nahda around the personal experiences of a handful of (elite and mainly exiled) individuals, understood in aesthetic terms ('literary staging'). It is not that personal experiences (or other questions that El-Ariss raises, such as the binary between East and West) are unimportant; nor that the emphasis on creative subjectivities is, in itself, unwelcome; but rather that the pressures upon them of material contexts and determinations recede, in El-Ariss's treatment, into a distant background, and we are left with individuals 'wrestling with modernity' (a generalised and largely culturally-conceived modernity), in intensely private ways. ${ }^{716}$ We can see, perhaps, an analogous though less pronounced tendency in Stephen Sheehi's work: though he does not relegate material processes to the background of his argument, he tends to subordinate them to questions of 'epistemology', 'identity', 'subjectivity', and the like; or to think of them in abstract, categorical terms ('capital', 'modernity') rather than in their specifics. ${ }^{717}$ This leads (as also in the work of Nadia Bou Ali) to an engagement, indeed, with 'material' histories, but through the lenses of 715 Trials of Arab Modernity, 12-13.

716 Certain of Aijaz Ahmad's strictures on Edward Said, in In Theory: Classes, Nations, Literatures (London and New York: Verso, 1994) - eclecticism, name-dropping ('Said, Adorno, Horkheimer, and al-Shidyaq all interrogate the canon and unsettle its episteme' - p. 86), an exclusive focus on the 'Third-World' intellectual who has moved to the imperial metropolis - seem to me doubly relevant to El-Ariss's book.

717 Thus, for instance. in 'Towards a Critical Theory of Al-Nahdah', 272: 'The new wave of Nahdah studies, if I may coin the term, locates the operative discourses on modernity and emergent subjectivities in the formation of new "social groups" and organic intellectuals, who, in turn, naturalized material and ideological conditions of nation-state and bourgeois selfhood.' It is with the emphases - discourses, subjectivities, selfhood, rather than, say, classes, production, social relations - that I take issue, as well as the tendency to abstraction. 
'idealist' terms. We can perhaps see here too, though to a lesser degree, that abstraction 'in all but the most general terms, from histories of production and social relationships', which Sumit Sarkar saw in the discourse analysis of the late Subaltern Studies school. ${ }^{718}$

Instead of rendering the social and political into private, aesthetic terms, or abstracting it into generalities, I have sought, in this study, to shift the argument out of the domain of the history of ideas (or 'representation') which postcolonial and postmodernist writers continue to dispute with 'orientalists' or believers in 'modernisation', and towards a consideration of the wider social dynamics which I analyse in my first chapter. Thus, for instance, I agree with Tageldin that there were powerful reasons for Arab elites to identify with Europe: we can see this above all in the attitude to European actions abroad implied in Hadiqat al$a k h b \bar{a} r$ 's coverage of the Indian 'Mutiny', the Opium War, and the French in Algeria. Europe, including European imperial domination, was on the side of civilisation, prosperity and order; rebellions against it were on that of chaos, ruin and barbarism. But we cannot regard the propensity to cultural 'dependency' on Europe which Tageldin describes - or, for that matter, the independence which some of my examples show - as unrelated to the position of these particular intellectuals, or bureaucrats, or capitalists, in relation to Europeans and to other social classes in their own societies.

It is in an attempt to re-place these cultural questions within their material context that I have tried to analyse Nahda writings, in this study, in relation to a hypothesis, derived from that of Mahdī 'Āmil, as to the socio-economic and above all the class formations of the ArabOttoman world in this period. This remains a hypothesis, rather than a fully substantiated conclusion (which would have required a rather different kind of study), and must be judged against other kinds of evidence than the 'cultural' in the narrow sense: economic and 718 Writing Social History, 4-5. 
political practices, regimes of law and custom. Ongoing work in these areas will doubtless permit its refinement or rejection. But pending this, it offers at least an argument as to the general shape of the 'material' context within which the Nahda existed (and of which it formed itself a part). Many links, of course, remain to be drawn - even within the midnineteenth century decades to which this study is confined, and in relation to the three specific 'formations' I study in Beirut, Egypt and Aleppo - most crucially perhaps in the area of the social organisations and institutions through which they operated. The majālis of the Aleppo Enlightenment; schools like Bustānī’s Madrasa Waṭaniyya; learned societies like the Syrian Scientific Society; the exchange of verses dedicated to particular individuals in the press and printed books; or the emergent theatre - all these might be examined (given sufficient sources) as at once institutions of cultural production and of sociability, of class- or elite-formation. Far more evidence of the kinds drawn on here - for instance from the press, or writing directly on economic and political matters - could of course be adduced; as well as other kinds, largely unexplored for this period - most notably, private writing, correspondence and the like. Some crucial political connections - between Syrian intellectuals and Ottoman statesmen, for instance - remain obscure. All I can hope to have done here is, first, to offer a plausible explanation for the - still largely literary - evidence with which I deal directly, which seems to me more satisfactory than one cast in purely culturalist terms; and, second, to suggest that it is to this kind of interrogation that we need to submit the evidence we possess of the period. As I see it, this offers a more fruitful approach to the realm of cultural activity and production which we may call 'the Nahda' than an attempt to read it against generalised, cultural notions ('modernity', 'encounter with Europe', 'identity' or 'authenticity'), or in the isolation of an aesthetic or subjective reading. Not that I mean to exclude the questions that these kinds of reading raise - but I do not think that, in the end, we can gain a satisfactory sense of why the people who made the Nahda acted, 
thought and wrote in the ways they did, without tracing the specific material contours of capitalism, imperialism, and state power, in that particular time and place. 


\section{Bibliography}

Abdelhady, Dalia. The Lebanese Diaspora: The Arab Immigrant Experience in Montreal, New York, and Paris. New York: NYU Press, 2011.

'Abduh, Muhammad. 'Al-Kutub Al- 'ilmiyya Wa-Ghayruha'. In Al-A 'māl Al-Kāmila Li-LImam Muhammad 'Abduh, edited by Muhammad 'Amara, 3:49-51. Beirut: alMu' assasa al-'Arabiyya li-l-dirāsa wa-l nashr, 1972.

Abu-Lughod, Ibrahim. The Arab Rediscovery of Europe: A Study in Cultural Encounters. London: Saqi, 2011.

— 'The Transformation of the Egyptian Élite: Prelude to the'Urābī Revolt'. The Middle East Journal, 1967, 325-44.

Abu-Manneh, Butrus. 'Shidyaq, Al-Jawa'ib, and the Call for Modernity in Ottoman Lands'. In The Economy as an Issue in the Middle Eastern Press, edited by Gisela Procházka-Eisl and Martin Strohmeier, 15-24. Münster: LIT Verlag, 2008.

- 'The Christians between Ottomanism and Syrian Nationalism: The Ideas of Butrus Al-Bustani'. International Journal of Middle East Studies 11, no. 3 (1980): 287-304.

- 'The Islamic Roots of the Gülhane Rescript'. Die Welt Des Islams 34, no. 2 (1994): 173-203.

'Afîfī, Muhammad. 'Arab Wa- 'Uthmāniyyun: ārā Mutaghāyira. Cairo: Dār al-Shurūq, 2005.

Ahmad, Aijaz. In Theory: Classes, Nations, Literatures. London and New York: Verso, 1994.

Aksan, Virginia H. 'Ottoman Political Writing, 1768-1808'. International Journal of Middle East Studies 25, no. 1 (1993): 53-69.

Al-Bagdadi, Nadia, Fawwaz Traboulsi, and Barbara Winckler, eds. A Life in Praise of Words: Ahmad Faris Al-Shidyaq and the Nineteenth Century. Literaturen Im Kontext. Arabisch - Persisch - Türkisch. Wiesbaden: Reichert, 2015.

Al Bassam, Sulayman. The Mirror for Princes - Kalila Wa Dimna. London: Oberon, 2006.

al-Disūqī, Ibrāhīm. Mukhtașar Jughrāfiyya. Bulaq: al-Maṭba'a al-Khudaywiyya, 1290.

Aldridge, Alfred Owen. 'Utopianism in World Literature'. Tamkang Review XIV, no. 1 (Autumn 1983): 11-30.

al-Ḥulw, Karam. Al-Fikr Al-Lībrālī 'inda Fransīs Al-Marrāsh : Binyatuhu Wa-Ușūluhu WaMawqi 'uhu Fī Al-Fikr Al- 'Arabī Al-hadīth (The Liberal Thought of Fransīs AlMarrāsh: Its Structure, Origins, and Place in Modern Arab Thought). Beirut: Markaz Dirāsāt al-Waḥda al-`Arabīya, 2006. 
al-Ḥumșī, Qusțākī. Udabā' Halab Dhuwū Al-Athar F̄̄ Al-Qarn Al-Tāsi ' 'ashar (Notable Literati of Aleppo in the Nineteenth Century). Aleppo: Maronite Press, 1925.

Allen, Roger. A Period of Time. Reading: Ithaca, 1992.

al-Majlis al-A ' lā li-l-thaqāfa, ed. Rifā'a Al-Ṭahṭāwī, Rā 'id Al-Tanwīr. Silsilat Abhāth AlMu'tamarāt 16. Cairo: al-Majlis al-A 'lā li-l-thaqāfa, 2007.

al-Sharīf, Māhir. 'Ru' yat Al-Marrāsh Li-L-Tamaddun Fī Ițār Khițāb 'așr Al-Nahḍa'. In Fransīs Fathallāh Marrāsh Rā'idan Nahdawiyyan Wa-Tanwīriyyan Baynanā (Fransīs Fathallāh Marrāsh: A Pioneer of Awakening and Enlightenment among Us), edited by Muḥammad Jamāl Bārūt and İmān al-Șāliḥ, 69-92. Beirut: Institut Français du Proche-Orient, forthcoming.

al-Shar', 'Alī. 'Al-Fikr Al-Ijtimā' '̄ F̄̄ Kitābāt Al-Marrāsh'. In Fransīs Fathallāh Marrāsh Rā'idan Nahdawiyyan Wa-Tanwīriyyan Baynanā (Fransīs Fathallāh Marrāsh: A Pioneer of Awakening and Enlightenment among Us), edited by Muhammad Jamāl Bārūt and Īmān al-Ṣāliḥ, 169-82. Beirut: Institut Français du Proche-Orient, forthcoming.

Fransīs Fathallāh Marrāsh Wa-Dawruhu F̄̄ Al-Nahḍa Al-Fikriyya Wa-L-Adabiyya Al-hadītha (Fransīs Fathallāh Marrāsh and His Role in the Modern Intellectual and Literary Awakening). Irbad, Jordan: Dar al-Kindi, 2008.

Ameuney, Antonius. Notes from the Life of a Syrian. London: W. Bennett, 1860.

'Āmil, Mahdī. Muqaddimāt nazariyya li-dirāsat athar al-fikr al-ishtirākī fì harakat altaharrur al-wațani (Theoretical Prolegomena to the Study of the Influence of Socialist Thought on the National Liberation Movement). Vol. 2. 2 vols. Beirut: Dār al-Fārābī, 1978.

Amin, Samir. Unequal Development: An Essay on the Social Formations of Peripheral Capitalism. Hassocks: Harvester, 1976.

Anderson, Benedict. Imagined Communities: Reflections on the Origin and Spread of Nationalism. London: Verso, 2006.

Anderson, Perry. Lineages of the Absolutist State. London: New Left Books, 1974.

Anon. Kitāb Tawārīkh Mukhtașar. Malta: Church Missionary Society Press, 1833.

—. Tārīkh Iskandar Dhī Al-Qarnayn Al-Makdūnī. [Beirut], n.d.

Anscombe, Frederick F. 'Islam and the Age of Ottoman Reform'. Past \& Present 208, no. 1 (2010): 159-89.

Antonius, George. The Arab Awakening: The Story of the Arab National Movement. Capricorn Books, 1946.

Ashraf, Mohammad, and Puran Chandra Joshi, eds. Rebellion, 1857: A Symposium. New 
Delhi: People’s Publishing House, 1957.

Ayalon, A. 'Modern Texts and Their Readers in Late Ottoman Palestine'. Middle Eastern Studies 38, no. 4 (2002).

Ayalon, Ami. 'Arab Booksellers and Bookshops in the Age of Printing, 1850-1914'. British Journal of Middle Eastern Studies 37, no. 1 (2010).

—. Language and Change in the Arab Middle East: The Evolution of Modern Arabic Political Discourse. Oxford and New York: Oxford University Press, 1987.

'Sihafa: The Arab Experiment in Journalism'. Middle Eastern Studies 28, no. 2 (1992): 258-80.

- 'The Arab Discovery of America in the Nineteenth Century'. Middle Eastern Studies 20, no. 4 (1984): 5-17.

- The Press in the Arab Middle East: A History. New York and Oxford: Oxford University Press, 1995.

- 'The Syrian Educated Elite and the Literary Nahda'. In Ottoman Reform and Muslim Regeneration, 127-48. I.B.Tauris, 2005.

Bārūt, Muhammad Jamāl. Harakat Al-Tanwīr Al- 'arabī F̄̄ Al-Qarn Al-Tāsi' 'ashar: halaqat Halab Numüdhajan (The Arab Enlightenment Movement in the Nineteenth Century: The Aleppo Circle as Model). Damascus: Ministry of Culture (Syria), 1994.

Bārūt, Muhammad Jamāl, and Īmān al-Șāliḥ, eds. Fransīs Fathallāh Marrāsh Rā idan Nahdawiyyan Wa-Tanwīriyyan Baynanā (Fransīs Fathallāh Marrāsh: A Pioneer of Awakening and Enlightenment among Us). Beirut: Institut Français du Proche-Orient, forthcoming.

Bashkin, Orit. 'Why Did Baghdadi Jews Stop Writing to Their Brethren in Mainz? - Some Comments about the Reading Practices of Iraqi Jews in the Nineteenth Century'. In History of Printing and Publishing in the Languages and Countries of the Middle East, edited by Philip Sadgrove. Journal of Semitic Studies Supplements 15. Oxford: Oxford University Press, 2004.

Batatu, Hanna. The Old Social Classes and the Revolutionary Movements of Iraq: A Study of Iraq's Old Landed and Commercial Classes and of Its Communists, Ba'thists, and Free Officers. Princeton: Princeton University Press, 1978.

Bauer, Thomas. 'Mamluk Literature: Misunderstandings and New Approaches'. Mamluk Studies Review 9, no. 2 (2005): 105-32.

Bawardi, Basiliyus. 'First Steps in Writing Arabic Narrative Fiction: The Case of Hadīqat AlAkhbār'. Die Welt Des Islams 48, no. 2 (2008): 170-95.

Beshara, Adel. The Origins of Syrian Nationhood: Histories, Pioneers and Identity. Abingdon and New York: Routledge, 2011. 
Black, Antony. The History of Islamic Political Thought: From the Prophet to the Present. 2nd ed. Edinburgh: Edinburgh University Press, 2011.

Blecher, Robert Ian. 'The Medicalization of Sovereignty: Medicine, Public Health, and Political Authority in Syria, 1861-1936'. Stanford University, 2002.

Booth, Marilyn. May Her Likes Be Multiplied: Biography and Gender Politics in Egypt. Berkeley and Los Angeles: University of California Press, 2001.

—. "She Herself Was the Ultimate Rule": Arabic Biographies of Missionary Teachers and Their Pupils'. Islam and Christian-Muslim Relations 13, no. 4 (2002): 427-48.

Bou Ali, Nadia. 'In the Hall of Mirrors: The Arab Nahda, Nationalism, and the Question of Language'. Doctoral thesis, Oxford, 2012.

Boustany, Joumana. 'La Production Des Imprimés Non Périodiques Au Liban de 1733 à 1920 : étude Bibliométrique'. Doctoral thesis, Université Michel de Montaigne, Bordeaux 3, 1997.

Brenner, Robert. 'The Origins of Capitalist Development: A Critique of Neo-Smithian Marxism'. New Left Review 104 (1977): 25-92.

Breuillard, Jean. 'Fragments d'Utopies Dans La Littérature Russe Du XVIIIe Siècle: Levšin et Xeraskov'. Revue Des études Slaves 56, no. 1 (1984): 17-31.

Briggs, Asa. The Age of Improvement, 1783-1867. London ; New York: Longmans, 1959.

Bruhns, C. (Carl), and Robert Avé-Lallemant. Alexander von Humboldt. Eine wissenschaftliche biographie. Leipzig, F.A. Brockhaus, 1872.

Bunyan, John. Siyāhhat Al-Masīḥ̄ (The Pilgrim’s Progress). Translated by Buṭrus al-Bustānī. Beirut: American Press, 1844.

. The Pilgrim's Progress. London, n. d.

Burke, Edmund. Selected Letters of Edmund Burke. Edited by Harvey C. Mansfield. Chicago and London: University of Chicago Press, 1984.

Bustān̄i, Buṭrus al-, ed. A 'māl Al-Jam 'iyya Al-Sūriyya Li-Iktisāb Al- 'ulūm Wa-L-Funūn. Vol. 1. Beirut: American Press, 1852.

'Khițāb F̄̄ Al-Hay'a Al-Ijtimā iyya Wa-L-Muqābala Bayna Al- 'awā' id Al-'arabiyya Wa-L-Ifranjiyya'. In Al-Mu 'allim Butrus Al-Bustān̄i : Dirāsa Wa-Wathā'iq, by Jān Dāyah. Beirut: Dār al-Fikr, 1981.

—. 'Khițāb F̄̄ Ta 'īm Al-Nisā'’. In Al-Mu 'allim Buṭrus Al-Bustān̄̄ : Dirāsa WaWathā'iq, by Jān Dāyah. Beirut: Dār al-Fikr, 1981.

. Kitāb Kashf Al-hijāb F̄̄ 'ilm Al-Hisāb. Beirut: American Press, 1848. 
—. Raw بạt Al-Tājir (The Merchant's Garden). Beirut: n. s., 1859.

Callahan, William A. 'Confucian Harmonizing: Utopia, Dystopia and Heterotopia in Chinese Thought'. Journal of Comparative Asian Development 2, no. 2 (2003): 233-57.

Calligaris, Colonel Chevalier Louis. Kitāb Sìrat Napulyūn Al-Awwal (Histoire de l'Empéreur Napoléon). 1st ed. Paris, 1856.

—. Kitāb Tārīkh Nabulyūn Bunabārtā Al-Awwal. 2nd ed. Beirut: al-Maṭba'a alwațaniyya, 1868.

Cave, Terence. 'Locating the Early Modern'. Paragraph 29, no. 1 (March 2006): 12-26. . Pré-Histoires: Textes Troublés Au Seuil de La Modernité. Vol. 1. Geneva: Droz,
1999.

Cheikho, Louis. Al-ādāb al- 'Arabiyya fì al-qarn al-tāsi' 'ashar. 2nd ed. Bayrūt: Jesuit Press, 1924.

Choueiri, Youssef. Modern Arab Historiography: Historical Discourse and the Nation-State. London: Routledge, 2003.

Clark, T. W. 'The Languages of Calcutta, 1760-1840'. Bulletin of the School of Oriental and African Studies 18, no. 3 (1956): 453-74.

Craig, Albert M. Civilization and Enlightenment: The Early Thought of Fukuzawa Yukichi. Cambridge, MA: Harvard University Press, 2009.

Cromer, Lord. Modern Egypt. London: Macmillan, 1908.

Cuno, Kenneth M. The Pasha's Peasants: Land, Society, and Economy in Lower Egypt, 1740-1858. Cambridge: Cambridge University Press, 1992.

Curtin, Philip D. Cross-Cultural Trade in World History. Cambridge: Cambridge University Press, 1984.

Dagher, Charbel. Al- 'Arabiyya wa-l-Tamaddun, fi Ishtibāh al- 'Alāqa bayn al-Nahḍ wa-lMuthāqafa wa-l-hadātha (The Arabic Language and Civilization: The Ambiguous Relationship Between Nahda, Cultural Exchange and Modernity). Beirut: Dār alNahār, 2002.

Dallāl, Nasrallāh Efendi Abdallāh. 'Al-Māl wa-l-A 'māl (Property and Labour)'. Al-Jinān, August 1870.

Dāyah, Jān. Al-Mu 'allim Buṭrus Al-Bustān̄̄ : Dirāsa Wa-Wathā iq. Beirut: Dār al-Fikr, 1981.

De Alba-Koch, Beatriz. 'The Dialogics of Utopia, Dystopia and Arcadia: Political Struggle and Utopian Novels in Nineteenth-Century Mexico'. Utopian Studies, 1997, 19-30.

Deeb, Lara. An Enchanted Modern: Gender and Public Piety in Shi'i Lebanon. Princeton 
University Press, 2006.

Defoe, Daniel. Robinson Crusoe. Edited by Michael Shinagel. Norton Critical Edition, 2nd edn. New York and London: Norton, 1994.

Depping, Georges-Bernard. Qalā'id al-mafākhir fì gharīb 'awā'id al-awā'il wa-l-awākhir (The Necklaces of Glories, on the Marvellous Customs of the Ancients and Moderns). Translated by Rifā‘a Rāfi‘ al-Ṭahțāwī. Bulaq, 1833.

Deringil, Selim. The Well-Protected Domains: Ideology and the Legitimation of Power in the Ottoman Empire, 1876-1909. London: IB Tauris, 1998.

El-Ariss, Tarek. Trials of Arab Modernity: Literary Affects and the New Political. New York: Fordham University Press, 2013.

Elshakry, Marwa. Reading Darwin in Arabic, 1860-1950. Chicago and London: University of Chicago Press, 2013.

- 'The Gospel of Science and American Evangelism in Late Ottoman Beirut'. Past \& Present 196, no. 1 (2007): 173-214.

Emerson, Ralph Waldo. Journals of Ralph Waldo Emerson. Vol. VI: 1841-44. Boston and New York: Houghton Mifflin, 1911.

Fahmy, Khaled. All the Pasha's Men: Mehmed Ali, His Army and the Making of Modern Egypt. Cambridge: Cambridge University Press, 1997.

Fahmy, Ziad. Ordinary Egyptians: Creating the Modern Nation through Popular Culture. Stanford: Stanford University Press, 2011.

Fakher Eldin, Munir. 'Communities of Owners: Land Law, Governance, and Politics in Palestine, 1858-1948'. Doctoral thesis, New York University, 2008.

Farah, Ceasar E. Politics of Interventionism in Ottoman Lebanon, 1830-1861. London: IB Tauris, 2000.

Farley, James Lewis. The Resources of Turkey Considered with Especial Reference to the Profitable Investment of Capital in the Ottoman Empire. London: Longman, Green, Longman and Roberts, 1862.

—. Two Years in Syria. London: Saunders and Otley, 1858.

Faroqhi, Suraiya. Approaching Ottoman History: An Introduction to the Sources. Cambridge: Cambridge University Press, 1999.

Fawaz, Leila Tarazi. An Occasion for War: Civil Conflict in Lebanon and Damascus in 1860. Berkeley: University of California Press, 1994.

Fayrūzābādī, Majd al-Dīn Muhammad b. Ya 'qūb al-. Al-Qāmūs Al-Muhīṭ. Edited by Muḥammad Na 'īm al-'Arqasūsī. 8th ed. Beirut: Mu'assasat al-Risāla, 2005. 
Feodorov, Ioana. 'Circumstances of a Special Relationship: Christian Arabs and Romanians during the 16th-18th Centuries'. Chronos. Revue d'Histoire de l'Université de Balamand, 2007, 95.

'Ottoman Authority in the Romanian Principalities as Witnessed by a Christian Arab Traveller of the 17th Century: Paul of Aleppo'. Orientalia Lovaniensia Analecta 148 (2006): 295-310.

Fieni, David. 'French Decadence, Arab Awakenings: Figures of Decay in the Arab Nahda'. Boundary 2 39, no. 2 (2012): 143-60.

Findley, Carter V. Bureaucratic Reform in the Ottoman Empire: The Sublime Porte, 17891922. Princeton Studies on the Near East. Princeton: Princeton University Press, 1980.

Firro, Kais. 'Silk and Agrarian Changes in Lebanon, 1860-1914'. International Journal of Middle East Studies 22, no. 2 (1990): 151-69.

Fleischer, Cornell. 'Royal Authority, Dynastic Cyclism, and "Ibn Khaldûnism" in SixteenthCentury Ottoman Letters'. African and Asian Studies 18, no. 3 (1 January 1983): 198-220.

Foster-Carter, Aidan. 'The Modes of Production Controversy'. New Left Review 107 (1978): $47-78$.

Fox-Genovese, Elizabeth, and Eugene D. Genovese. Fruits of Merchant Capital: Slavery and Bourgeois Property in the Rise and Expansion of Capitalism. New York: Oxford University Press, 1983.

Gekas, Athanasios (Sakis). 'Class and Cosmopolitanism: The Historiographical Fortunes of Merchants in Eastern Mediterranean Ports'. Mediterranean Historical Review 24, no. 2 (2009): 95-114.

Gellner, Ernest. Nations and Nationalism. Oxford: Basil Blackwell, 1983.

Ghazzal, Zouhair. 'Chapter Four: The "Ulama": Status and Function'. In A Companion to the History of the Middle East, edited by Youssef M. Choueiri, 72-86. Oxford: Blackwell, 2005.

Godelier, Maurice. L'Idéel et le matériel: Pensée, économies, sociétés. Paris: Fayard, 1984.

—. 'Ordres, Classes, Etat Chez Marx'. In Visions Sur Le Développement Des Etats Européens. Théories et Historiographies de l'État Moderne. Actes Du Colloque de Rome (18-31 Mars 1990), 117-35. Rome: Ecole Française de Rome, 1993.

Godlewska, Anne. Geography Unbound: French Geographic Science from Cassini to Humboldt. Chicago and London: University of Chicago Press, 1999.

Graeber, David. Debt: The First 5,000 Years. New York: Melville House, 2011. 
Grallert, Till. 'To Whom Belong the Streets? Property, Propriety, Appropriation: The Production of Public Space in Late Ottoman Damascus, 1875-1914.' Doctoral thesis, Freie Universität Berlin, 2014.

Gramsci, Antonio. Selections from the Prison Notebooks. Translated by G. Nowell-Smith and Q. Hoare. London: Lawrence and Wishart, 1971.

Gran, Peter. "Passive Revolution" as a Possible Model for Nineteenth-Century Egyptian History'. In Money, Land and Trade: An Economic History of the Muslim Mediterranean, edited by Nelly Hanna, 84. The Islamic Mediterranean. London: I.B.Tauris, 2002.

Greenstein, Ran. 'A Palestinian Revolutionary: Jabra Nicola and the Radical Left'. Jerusalem Quarterly 46 (2009): 32-48.

Gregory, Derek. Geographical Imaginations. Cambridge, MA and Oxford: Blackwell, 1994.

Guizot, François. Kitāb Al-Tuhfa Al-Adabiyya F̄̄ Tārīkh Tamaddun Al-Mamālik AlÜrubāwiyya. Translated by Hanīn Ni 'matallāh Khūrī. Alexandria: Maṭba'at alAhrām, 1877.

- Kitāb Al-Tuhfa Al-Adabiyya F̄̄ Tārīkh Tamaddun Al-Mamālik Al-Ūrubāwiyya. Edited by Yūsuf Qizmā Khūrī. Translated by Ḥan̄̄n Ni 'matallāh Khūrī. Beirut: Dār al-Ḥamrā', 1990.

Guth, Stephan. Brückenschläge: Eine Integrierte »turkoarabische« Romangeschichte (Mitte 19. Bis Mitte 20. Jahrhundert). Literaturen Im Kontext. Arabisch - Persisch Türkisch. Wiesbaden: Reichert, 2003.

Haddad, Robert M. Syrian Christians in Muslim Society: An Interpretation. Princeton: Princeton University Press, 1970.

Hafez, Sabry. The Genesis of Arabic Narrative Discourse: A Study in the Sociology of Modern Arabic Literature. London: Saqi, 1993.

Haidar, Otared. 'Aleppo: The First Ground for Arab-European Cultural Encounters in the Early Modern Period'. In From Ancient Arabia to Modern Cairo: Papers from the BRISMES Annual Conference 2009, edited by Philip Sadgrove, 127-38. Journal of Semitic Studies Supplements 28. Oxford: Oxford University Press, 2012.

Halliday, Fred. 'The Millet of Manchester: Arab Merchants and Cotton Trade'. British Journal of Middle Eastern Studies 19, no. 2 (1992): 159-76.

Hanioğlu, M. Şükrü. 'Blueprints for a Future Society: Late Ottoman Materialists on Science, Religion, and Art'. In Late Ottoman Society: The Intellectual Legacy, edited by Elisabeth Özdalga, 28-116. Abingdon: Routledge Curzon, 2005.

Hanssen, Jens. Fin de Siècle Beirut: The Making of an Ottoman Provincial Capital. Oxford and New York: Oxford University Press, 2005. 
_. "Malhamé-malfamé": Levantine Elites and Transimperial Networks on the Eve of the Young Turk Revolution'. International Journal of Middle East Studies 43, no. 1 (2011): 25-48.

Heyberger, Bernard. Hindiyya, Mystic and Criminal, 1720-1798: A Political and Religious Crisis in Lebanon. Translated by Renée Champion. Cambridge: James Clarke, 2013.

- Les Chrétiens Du Proche-Orient Au Temps de La Réforme Catholique, Syrie, Liban, Palestine, XVIIe-XVIIIe Siècles. Rome: École française de Rome, 1994.

Heyworth-Dunne, James. 'Printing and Translations under Muhammad 'Alī of Egypt: The Foundation of Modern Arabic'. Journal of the Royal Asiatic Society of Great Britain and Ireland, no. 3 (1940): 325-49.

Hill, Christopher. Puritanism and Revolution: Studies in Interpretation of the English Revolution of the 17th Century. London: Panther, 1968.

Hill, Peter. 'Early Arabic Translations of English Fiction: The Pilgrim's Progress and Robinson Crusoe'. Journal of Semitic Studies LX, no. 1 (2015): 177-212.

_ . 'Revisiting the Intellectual Space of the Nahḍa (Eighteenth-Twentieth Centuries)'. Les Carnets de l'Ifpo, 5 June 2014. http://ifpo.hypotheses.org/6013.

- 'The First Arabic Translations of Enlightenment Literature: The Damietta Circle of the 1800s and 1810s'. Intellectual History Review 24, no. 2 (2015): 209-33.

Hobsbawm, E. J. The Age of Empire, 1875-1914. London: Weidenfeld \& Nicolson, 1987.

Hobsbawm, Eric. On History. London: Hachette UK, 2011.

—. The Age of Capital. London: Abacus, 1995.

Holt, Elizabeth M. 'Narrative and the Reading Public in 1870s Beirut'. Journal of Arabic Literature 40, no. 1 (2009): 37-70.

- 'Serialization and Silk: The Emergence of a Narrative Reading Public of Arabic in Beirut, 1870-1884'. Doctoral thesis, Columbia University, 2010.

Hosny, Manal Gamal El Din. 'Tradition et Renouveau Dans L'oeuvre de Tahtawi'. Doctoral thesis, Alexandria University, 2001.

Hourani, Albert. Arabic Thought in the Liberal Age, 1798-1939. London: Oxford University Press, 1962.

- 'Ottoman Reform and the Politics of Notables'. In The Emergence of the Modern Middle East, 36-66. Berkeley and Los Angeles: University of California Press, 1981.

- The Emergence of the Modern Middle East. Berkeley and Los Angeles: University of California Press, 1981. 
Hsu, C.-H. 'A Survey of Arabic-Character Publications Printed in Egypt during the Period of 1238-1267 (1822-1851)'. In History of Printing and Publishing in the Languages and Countries of the Middle East, edited by Philip Sadgrove. Journal of Semitic Studies Supplements 15. Oxford: Oxford University Press, 2004.

Hua, Shiping. Chinese Utopianism: A Comparative Study of Reformist Thought with Japan and Russia, 1898-1997. Washington, DC: Woodrow Wilson Center, 2009.

Humphrey, Michael. 'Lebanese Identities: Between Cities, Nations and Trans-Nations'. Arab Studies Quarterly, 2004, 31-50.

Hunter, F. Robert. 'Egypt's High Officials in Transition from a Turkish to a Modern Administrative Elite, 1849-1879'. Middle Eastern Studies 19, no. 3 (July 1983): 277-300.

- Egypt under the Khedives, 1805-1879: From Household Government to Modern Bureaucracy. Cairo: American University in Cairo Press, 1999.

Husayn, Țāhā. Mustaqbal Al-Thaqāfa Fī Miṣr. Cairo: Dār al-Ma ārif, 1938.

Hussein, Taha. The Future of Culture in Egypt. Translated by Sidney Glazer. Washington, DC: American Council of Learned Societies, 1956.

'Abbās Hāmid, Ra'ūf, and Assem El-Dessouky. The Large Landowning Class and the Peasantry in Egypt, 1837-1952. Syracuse, NY: Syracuse University Press, 2011.

Ibn Khaldūn. The Muqaddimah: An Introduction to History. Edited by Franz Rosenthal. Translated by N. J. Dawood. New York: Pantheon, 1958.

Ibrahim, Hassan Ahmed. 'The Egyptian Empire, 1805-1885'. In The Cambridge History of Egypt, 2: Modern Egypt:, From 1517 to the End of the Twentieth Century:198-216. Cambridge: Cambridge University Press, 1998.

İhsanoğlu, Ekmeleddin. The Turks in Egypt and Their Cultural Legacy. Cairo: American University in Cairo Press, 2013.

İnalc1k, Halil. Studies in Ottoman Social and Economic History. Collected Studies 214. London: Variorum Reprints, 1985.

Islamogu-Inan, Huri. The Ottoman Empire and the World-Economy. Cambridge: Cambridge University Press, 1987.

Issawi, Charles. 'British Trade and the Rise of Beirut, 1830-1860'. International Journal of Middle East Studies 8, no. 1 (1977): 91-101.

Jackson, Stanley. The Sassoons. New York: Dutton, 1968.

Jalāl, Īmān al-Sa '̄id. Al-Muștalah 'ind Rifā'a Al-Tahțāwī: Bayn Al-Tarjama Wa-L-Ta 'rīb. Cairo: Maktabat al-Ādāb, 2006. 
Jameson, Fredric. The Political Unconscious: Narrative as a Socially Symbolic Act. London: Methuen, 1981.

Ja far, Nadhir. 'Bunyat Al-Lugha Al-Sardiyya Fi "Ghābat Al-ḥaqq"'. In Fransīs Fathallāh Marrāsh Rā'idan Nahḍwiyyan Wa-Tanwīriyyan Baynanā (Fransīs Fathallāh Marrāsh: A Pioneer of Awakening and Enlightenment among Us), edited by Muhammad Jamāl Bārūt and Īmān al-Ṣāliḥ, 205-12. Beirut: Institut Français du Proche-Orient, forthcoming.

Kasaba, Reşat. 'Was There a Compradore Bourgeoisie in Mid-Nineteenth-Century Western Anatolia?' Review (Fernand Braudel Center), 1988, 215-28.

Kassir, Samir. Beirut. Berkeley: University of California Press, 2010.

Kayat, Assaad J. A Voice from Lebanon. London: Madden \& Company, 1847.

Kenny, Lorne M. 'The Khedive Isma'il's Dream of Civilization and Progress'. The Muslim World 55, no. 2 (1965): 142-55.

Khayat, Nicole. 'Historiography and Occidentalism during the 19th Century Nahda: European History in Arabic'. Doctoral thesis, Haifa University, forthcoming.

Khoury, Philip S. Urban Notables and Arab Nationalism: The Politics of Damascus 18601920. Cambridge: Cambridge University Press, 2003.

Khūrī, Khalīl al-. Kharābāt Sūriyya. Beirut: al-Maṭba' a al-Sūriyya, 1860.

—. Way, Idhan Lastu Bi-Ifranjī. 2nd ed. Beirut: al-Maṭba 'a al-Sūriyya, 1860.

- Way, Idhan Lastu Bi-Ifranjī: Awwal Riwāyah 'Arabiyya. Facsimile. Cairo: al-Majlis al-A' lā li-1-thaqāfa, 2007.

Khuri-Makdisi, Ilham. The Eastern Mediterranean and the Making of Global Radicalism, 1860-1914. Berkeley and Los Angeles: University of California Press, 2010.

Khūrī, Yūsuf Q. Rajul sābiq li- 'aṣrihi: al-mu'allim Buṭus al-Bustānī, 1819-1883. Amman: Bīsān, 1995.

Khūrī, Yūsuf Qizmā, ed. A 'māl Al-Jam ‘iyya Al- ilmiyya Al-Sūriyya, 1868-1869. Beirut: Dār al-Hamrā', 1990.

Kiernan, V. G. Marxism and Imperialism: Studies. London: Edward Arnold, 1974.

- 'Review of Raymond Williams, Culture and Society, 1780-1950'. New Reasoner, no. 9 (Summer 1959).

Kiernan, Victor Gordon. The Lords of Human Kind: Black Man, Yellow Man, and White Man in an Age of Empire. London: Cresset Library, 1988.

Kim, Sung Ho. 'Max Weber'. In The Stanford Encyclopedia of Philosophy, edited by 
Edward N. Zalta, Fall 2012., 2012.

http://plato.stanford.edu/archives/fall2012/entries/weber/.

Kratchkovsky, Ignati Iulianovich. Tārīkh al-adab al-jughräfì al- 'Arabī (History of Arabic Geographical Literature). Translated by Șālāḥ al-Dīn 'Uthmān Hāshim. 2 vols. Cairo: Lajnat al-Ta'līf wa-al-Tarjamah wa-al-Nashr, 1963.

Kremer, Alfred Freiherr von. 'Ein Jahr in Beirut'. Das Ausland (Augsburg), 1872.

Krimsti, Feras. 'The 1850 Uprising in Aleppo. Reconsidering the Explanatory Power of Sectarian Argumentations'. In Urban Violence in the Middle East. Changing Cityscapes in the Transition from Empire to Nation State, edited by U. Freitag and N. Fuccaro, 141-63. New York and Oxford: Berghahn, 2015.

Kristó-Nagy, István. La Pensée d'Ibn Al-Muqaffa'. Un «agent Double» Dans Le Monde Persan et Arabe. Studia Iranica, XIX. Versailles: Éditions de Paris, 2013.

Laffan, Michael. 'The New Turn to Mecca. Snapshots of Arabic Printing and Sufi Networks in Late 19th Century Java'. Revue Des Mondes Musulmans et de La Méditerranée, no. 124 (2008): 113-31.

Landes, David S. Bankers and Pashas: International Finance and Economic Imperialism in Egypt. Cambridge, MA: Harvard University Press, 1958.

Lawrence, T. E. Seven Pillars of Wisdom: A Triumph. London: Manning Pike, 1926.

Levy, Lital. 'Jewish Writers in the Arab East: Literature, History, and the Politics of Enlightenment, 1863-1914'. Doctoral thesis, University of California, 2007.

_ . "The Nahḍa and the Haskala: A Comparative Reading of "Revival" and "Reform". Middle Eastern Literatures 16, no. 3 (1 December 2013): 300-316.

Lewis, Bernard. The Emergence of Modern Turkey. London: Oxford University Press, 1968.

. The Political Language of Islam. Chicago ; London: University of Chicago Press, 1988.

Livingstone, David N., and Charles W. J. Withers. Geography and Enlightenment. Chicago and London: University of Chicago Press; 1999.

Love, Joseph L. 'Utopianism in Latin American Cultures'. In Aware of Utopia (Conference on Utopia in Comparative Focus), edited by David W. Plath, 117-34. Urbana: University of Illinois Press, 1971.

Lutsky, Vladimir B. Modern History of the Arab Countries. Translated by Lika Nasser. Moscow: Progress Publishers, 1969.

Lützelschwab, Claude. La Compagnie Genevoise Des Colonies Suisses de Sétif (18531956): Un Cas de Colonisation Privée En Algérie. Bern: Peter Lang, 2006. 
Makdisi, Ussama. 'After 1860: Debating Religion, Reform, and Nationalism in the Ottoman Empire'. International Journal of Middle East Studies 34, no. 4 (2002).

- Artillery of Heaven: American Missionaries and the Failed Conversion of the Middle East. Ithaca, NY: Cornell University Press, 2008.

—. 'Corrupting the Sublime Sultanate: The Revolt of Tanyus Shahin in NineteenthCentury Ottoman Lebanon'. Comparative Studies in Society and History 42, no. 1 (2000): 180-208.

—. 'Ottoman Orientalism'. The American Historical Review 107, no. 3 (2002): 768-96.

- The Culture of Sectarianism: Community, History, and Violence in NineteenthCentury Ottoman Lebanon. Berkeley and Los Angeles: University of California Press, 2000.

Malte-Brun, Conrad. al-Jughrāfìya al- 'umūmīya. Translated by Rifā'a al-Ṭahțāwī. Būlāq: sn, 1838.

- Précis de la géographie universelle, ou Description de toutes les parties du monde, sur un plan nouveau... Paris: Fr. Buisson, 1812.

- Universal Geography: Or A Description of All Parts of the World, on a New Plan... Philadelphia: A. Finley, 1827.

Mannheim, Karl. Ideology and Utopia: An Introduction to the Sociology of Knowledge. London: Routledge \& Kegan Paul, 1949.

Manuel, Frank Edward. Utopian Thought in the Western World. Cambridge, Mass: Belknap Press, 1979.

Ma'oz, Moshe. Ottoman Reform in Syria and Palestine, 1840-1861: The Impact of the Tanzimat on Politics and Society. Oxford: Oxford University Press, 1968.

Maqrīzī, Aḥmad ibn 'Alī. Kitāab al-Mawā 'iz wa-al-i 'tibār bi-dhikr al-khițaṭ wa-al-āthār . Būlāq: Dār al-Ṭibā'a al-Miṣriyya, 1270.

Mardin, Şerif. The Genesis of Young Ottoman Thought: A Study in the Modernization of Turkish Political Ideas. Syracuse, NY: Syracuse University Press, 1962.

Mariette, Auguste Bey. Aperçu de l'histoire d'Égypte : depuis les temps les plus reculés jusqu'à la conquête musulmane. Alexandria: Mourès, Rey, 1864.

Marrāsh al-Ḥalabī, al-Khawājā Fransīs Fatḥallāh. Kitāb Riḥlat Bārīs. Beirut: al-Maṭba'a alSharqiyya 'ind Ḥannā Najjār, 1867.

Marsot, Afaf Lutfi al-Sayyid. Egypt in the Reign of Muhammad Ali. Cambridge: Cambridge University Press, 1984.

Masters, Bruce. 'Arabistan (the Arabic-Speaking Lands)'. Edited by Bruce Masters and 
Gábor Ágoston. Encyclopedia of the Ottoman Empire. New York: Facts on File, Inc., 2009.

. 'The 1850 Events in Aleppo: An Aftershock of Syria's Incorporation into the Capitalist World System'. International Journal of Middle East Studies 22, no. 1 (1990): 3-20.

- 'The Political Economy of Aleppo in an Age of Ottoman Reform'. Journal of the Economic and Social History of the Orient 53, no. 1-2 (2010): 1-2.

_ . 'Trading Diasporas and "Nations": The Genesis of National Identities in Ottoman Aleppo'. The International History Review 9, no. 3 (1987): 345-67.

Ma 'lūf, 'Īsā Iskandar. ‘Al-Khūrī 'Īsā Bitrū Al-Ūrshalīmī’. Majallat Al-Ni ‘ma, December 1911.

McDougall, James. 'A World No Longer Shared: Losing the Droit de Cité in NineteenthCentury Algiers'. Unpublished manuscript, n.d.

- History and the Culture of Nationalism in Algeria. Cambridge: Cambridge University Press, 2006.

McDougall, Mary Lynn. 'Consciousness and Community: The Workers of Lyon, 18301850'. Journal of Social History 12, no. 1 (1978): 129-45.

Meissas, Achille, and Jean Charles Auguste Michelot. Nouvelle géographie méthodique. Paris: Hachette, 1835.

—. Risale-i coğrafya. Translated by Bogos Tiryakioğlu. Istanbul: s.n., 1849.

Merle d'Aubigné, J. H. Tārīkh al-iṣlāh fì al-qarn al-sādis 'ashar (History of the Reformation in the Sixteenth Century). Translated by Cornelius V. A. Van Dyck. Beirut: American Press, 1878.

Mestyan, Adam. “"A Garden With Mellow Fruits Of Refinement” - Music Theatres And Cultural Politics In Cairo And Istanbul, 1867-1892'. Doctoral thesis, Central European University, 2011.

. 'Arabic Lexicography and European Aesthetics: The Origin of Fann'. Muqarnas 28 (2011): 69-100.

- , ed. 'Project Jara'id: A Chronology of Nineteenth Century Periodicals in Arabic (1800-1900)', and ongoing 2012. http://www.zmo.de/jaraid/HTML/index.html.

Meyer, Maisie. 'Baghdadi Jewish Merchants in Shanghai and the Opium Trade'. Jewish Culture and History 2, no. 1 (1999): 58-71.

Mishāqa, Mikhā'īl. Al-Burhān 'alā du f Al-Insān (Proof of the Weakness of Man). Beirut: American Press, 1853. 
—. Al-Dalīl Ilā țā 'at Al-Injīl (Guide to Obedience to the Gospel). Beirut: American Press, 1849.

- Muntakhabāt Min Al-Jawāb 'alā Iqtirāḥ Al-Aḥbāb. Beirut: Ministry of Education and Arts, 1955.

Mitchell, Timothy. Colonising Egypt. Berkeley: University of California Press, 1991.

M'Kerrow, Rev. John. History of the Foreign Missions of the Secession \& United Presbyterian Church. Edinburgh: Andrew Elliot, 1867.

Moichi, Yoriko. 'Japanese Utopian Literature from the 1870s to the Present and the Influence of Western Utopianism’. Utopian Studies 10, no. 2 (1999): 89-97.

Mondal, Anshuman A. 'Between Turban and Tarbush: Modernity and the Anxieties of Transition in Hadith 'Isa Ibn Hisham'. Alif, no. 17 (1997): 201-21.

Moore. 'Report by Mr. Acting Consul-General Moore on the Trade of Beyrout for the Year 1861.' House of Commons Parliamentary Papers 1863, no. LXX (1863): 448-51.

Moosa, Matti. The Origins of Modern Arabic Fiction. 2nd ed. Boulder, CO and London: Three Continents Press, 1997.

Moretti, Franco. The Bourgeois : Between History and Literature. London: Verso, 2013.

Morton, A. L. The English Utopia. London: Lawrence \& Wishart, 1952.

—. 'Utopia as a Reflection of Social Ideas'. Marxism Today, November 1962, 336-42.

Nagasawa, Eiji. Modern Egypt Through Japanese Eyes: A Study on Intellectual and SocioEconomic Aspects of Egyptian Nationalism. Cairo: Merit, 2009.

Naregal, Veena. 'The Mutiny in Western India: The 'Marginal' as Regional Dynamic.' In Mutiny at the Margins: New Perspectives on the Indian Uprising of 1857, Volume I: Anticipations and Experiences in the Locality, edited by Crispin Bates, 169-88. New Delhi: SAGE, 2013.

Nuita, Seiji. 'Traditional Utopias in Japan and the West: A Study in Contrasts'. In Aware of Utopia (Conference on Utopia in Comparative Focus), edited by David W. Plath, 12 32. Urbana: University of Illinois Press, 1971.

Omar, Hussein. 'Arabic Thought in the Liberal Cage'. In Beyond Muslim Liberalism, edited by Faisal Devji and Zaheer Kazemi. London: Hurst, 2016.

O’Meara, Dominic J. Platonopolis: Platonic Political Philosophy in Late Antiquity. Oxford: Clarendon, 2003.

Omri, Mohamed-Salah. 'Local Narrative Form and Constructions of the Arabic Novel'. Novel: A Forum on Fiction 41, no. 2-3 (Spring/Summer 2008): 244-63. 
Osman, Ghada, and Camille F. Forbes. 'Representing the West in the Arabic Language: The Slave Narrative of Omar Ibn Said'. Journal of Islamic Studies 15, no. 3 (2004): 33143.

Owen, Roger. Cotton and the Egyptian Economy, 1820-1914: A Study in Trade and Development. Oxford: Clarendon Press, 1969.

_. 'Lebanese Silk Industry'. In The Ottoman Empire and the World-Economy, edited by Huri Islamogu-Inan. Cambridge: Cambridge University Press, 1989.

—. The Middle East in the World Economy, 1800-1914. London: IB Tauris, 1993.

Panov, V. P. 'Comprador Bourgeoisie'. The Great Soviet Encyclopedia, 791970. http://encyclopedia2.thefreedictionary.com/Comprador+Bourgeoisie.

Patel, Abdulrazzak. The Arab Nahdah: The Making of the Intellectual and Humanist Movement. Edinburgh: Edinburgh University Press, 2013.

Pernau, Margrit, Helge Jordheim, Emmanuelle Saada, Christian Bailey, Einar Wigen, Orit Bashkin, Mana Kia, et al. Civilizing Emotions: Concepts in Asia and Europe, 18701920. Oxford and New York: Oxford University Press, 2015.

Philipp, Thomas. Acre: The Rise and Fall of a Palestinian City, 1730-1831. New York: Columbia University Press, 2001.

'Bilād Al-Šām in the Modern Period: Integration into the Ottoman Empire and New Relations with Europe'. Arabica 51, no. 4 (2004): 401-18.

. 'The Farhi Family and the Changing Position of the Jews in Syria, 1750-1860'. Middle Eastern Studies 20, no. 4 (1984): 37-52.

—. The Syrians in Egypt, 1725-1975. Stuttgart: Franz Steiner, 1985.

Pierse, Síofra. 'Voltaire: Polemical Possibilities of History'. In A Companion to Enlightenment Historiography, edited by Robert Sparling and Sophie Bourgault, 153-87. Leiden: Brill, 2013.

Pocock, J. G. A. 'Perceptions of Modernity in Early Modern Historical Thinking'. Intellectual History Review 17, no. 1 (2007): 79-92.

Pollard, Lisa. Nurturing the Nation: The Family Politics of Modernizing, Colonizing, and Liberating Egypt, 1805-1923. Berkeley: University of California Press, 2005.

Porter, Roy. Enlightenment: Britain and the Creation of the Modern World. London: Penguin, 2001.

Powell, Eve Troutt. A Different Shade of Colonialism: Egypt, Great Britain, and the Mastery of the Sudan. Berkeley and Los Angeles: University of California Press, 2003.

Quataert, Donald, Erik Jan Zürcher, and International Institute of Social History. Workers 
and the Working Class in the Ottoman Empire and the Turkish Republic, 1839-1950. London: Tauris, 1995.

Quilty, M. James. 'Bridging the Dichotomy: Socio-Economic Change and Class Consolidation in Ottoman Beirut and Damascus'. Doctoral thesis, Simon Fraser University, 1992.

Rastegar, Kamran. 'Introduction'. Middle Eastern Literatures 16, no. 3 (1 December 2013): $227-31$.

Rebhan, Helga. Geschichte und Funktion einiger politischer Termini im Arabischen des 19. Jahrhunderts, 1798-1882. Wiesbaden: Harrassowitz, 1986.

Reid, Donald M. 'Syrian Christians, the Rags-to-Riches Story, and Free Enterprise'. International Journal of Middle East Studies 1, no. 4 (1970): 358-67.

Ricardo, David. Principles of Political Economy and Taxation. Library of Economics and Liberty, 1817. http://www.econlib.org/library/Ricardo/ricP2a.html.

Richter-Bernburg, L. 'Geographical Literature'. Edited by Julie Scott Meisami and Paul Starkey. Encyclopedia of Arabic Literature. London and New York: Routledge, 1998.

Rifā'a al-Ṭahțāwī. An Imam in Paris: Account of a Stay in France by an Egyptian Cleric, 1826-1831. Translated by Daniel L. Newman. London: Saqi, 2004.

Rizk, Père Karam, and Dominique Avon, eds. La Nahda : Réveils de La Pensée En Langue Arabe. Approches. Perspectives (Colloque Organisé à l'USEK Les 28-29 Octobre 2004). Kaslik: Presses de l’Université Saint-Esprit de Kaslik, 2009.

Robertson, William, and Khalīfa ibn Maḥmūd. Kitāb Itḥāf al-mulūk al-alibbā' bi-taqaddum al-jam 'iyyāt fì bilād Ūrūbbā: wa-huwa al-muqaddimah li-tārīkh al-Imbirāțūr Sharlakān. Cairo: Maṭba'at Būlāq, 1258.

Rochlin, Samuel A. 'Early Arabic Printing at the Cape of Good Hope'. Bulletin of the School of Oriental and African Studies 7, no. 1 (1933): 49-54.

Roded, Ruth. 'The Syrian Urban Notables: Elite, Estates, Class?' Asian and African Studies 20 (1986): 375-84.

Rogan, Eugene L. 'Sectarianism and Social Conflict in Damascus: The 1860 Events Reconsidered'. Arabica 51, no. 4 (2004): 493-511.

Roper, Geoffrey. 'Arabic Printing in Malta 1825-1845: Its History and Its Place in the Development of Print Culture in the Arab Middle East.' University of Durham, 1988.

Roth, Cecil. The Sassoon Dynasty. New York: Arno Press, 1977.

Ryzova, Lucie. The Age of the Efendiyya: Passages to Modernity in National-Colonial Egypt. Oxford University Press, 2013. 
Sacks, Jeffrey. 'Futures of Literature: Inhitat, Adab, Naqd'. Diacritics 37, no. 4 (2007): 3255.

Sadgrove, Philip. The Egyptian Theatre in the Nineteenth Century: 1799-1882. Reading: Garnet \& Ithaca Press, 1996.

Salāma, Yūsuf. ‘Al-Hurriyya Fi Fikr Fransīs Al-Marrāsh'. In Fransīs Fathallāh Marrāsh Rāìdan Nahdawiyyan Wa-Tanwīriyyan Baynanā (Fransīs Fathallāh Marrāsh: A Pioneer of Awakening and Enlightenment among $U_{S}$ ), edited by Muhammad Jamāl Bārūt and Īmān al-Ṣāliḥ, 105-14. Beirut: Institut Français du Proche-Orient, forthcoming.

Salisbury, Edward E. 'II. Syrian Society of Arts and Sciences'. Journal of the American Oriental Society 3 (1853): 477-86.

Sarkar, Sumit. 'The Complexities of Young Bengal'. Nineteenth Century Studies (Calcutta) 4 (1973): 504-34.

—. Writing Social History. Delhi: Oxford University Press, 1997.

Sawaie, Mohammed. Azmat Al-Muștalah̆ Al- 'Arabī F̄̄ Al-Qarn Al-Tāsi' 'ashar (La Crise de La Terminologie Arabe Au XIXe Siècle. Introduction Historique Générale).

Damascus: Institut Français de Damas, 1999.

Schilcher, Linda Schatkowski. Families in Politics: Damascene Factions and Estates of the 18th and 19th Centuries. Wiesbaden: F. Steiner, 1985.

Selim, Samah. The Novel and the Rural Imaginary in Egypt, 1880-1985. Albany, NY: SUNY Press, 2004.

Sharīf, Māhir al-. Rihānāt Al-Nahḍ F̄̄ Al-Fikr Al- 'Arabī (The Stakes of the Nahda in Arab Thought). Damascus: Dār al-Madā, 2000.

Shayyāl, Jamāl al-Dīn. Tārīkh Al-Tarjama Wa-L-ḥaraka Al-Thaqāfiyya Fī 'așr Muhammad 'Ali (History of Translation and the Cultural Movement in the Age of Muhammad Ali). Cairo: Dār al-Fikr al-'Arabī, 1951.

Sheehi, Stephen. 'Arabic Literary-Scientific Journals: Precedence for Globalization and the Creation of Modernity'. Comparative Studies of South Asia, Africa and the Middle East 25, no. 2 (2005): 438-48.

Foundations of Modern Arab Identity. Gainesville, Florida: University Press of Florida, 2004.

. 'Towards a Critical Theory of Al-Nahdah: Epistemology, Ideology and Capital'. Journal of Arabic Literature 43, no. 2-3 (1 January 2012): 269-98.

'Unpacking Modern Arab Subjectivity: Reading Al-Mu'allim Butrus Al-Bustani's" Nafir Suriya"”. The Arab Studies Journal, 1998, 87-99. 
Sheehi, Stephen Paul. 'Inscribing the Arab Self: Butrus Al-Bustani and Paradigms of Subjective Reform'. British Journal of Middle Eastern Studies 27, no. 1 (2000): 724.

Shidyāq, Fāris. Leg over Leg. Translated by Humphrey Davies. 4 vols. Library of Arabic Literature. New York: NYU Press, 2013.

Silvera, Alain. 'The First Egyptian Student Mission to France under Muhammad Ali'. Middle Eastern Studies 16, no. 2 (1980): 1-22.

Sinha, Manisha. 'Eugene D. Genovese: The Mind of a Marxist Conservative'. Radical History Review 88, no. 1 (2004): 4-29.

Sluglett, Peter. 'Aspects of Economy and Society in the Syrian Provinces: Aleppo in Transition, 1880-1925'. In Modernity and Culture: From the Mediterranean to the Indian Ocean, Leila Fawwaz, Christopher Bayly and Robert Ilbert. New York: Columbia University Press, 2002.

Smith, Adam. Wealth of Nations. Library of Economics and Liberty, 1776. http://www.econlib.org/library/Smith/smWN17.html.

Somekh, S. 'The Neo-Classical Arabic Poets'. In Modern Arabic Literature, edited by M. M. Badawi, 36-81. Cambridge History of Arabic Literature. Cambridge: Cambridge University Press, 1993.

Staum, Martin S. Cabanis: Enlightenment and Medical Philosophy in the French Revolution. Princeton: Princeton University Press, 1980.

Stein, Sarah Abrevaya. 'Protected Persons? The Baghdadi Jewish Diaspora, the British State, and the Persistence of Empire'. The American Historical Review 116, no. 1 (2011): $80-108$.

Stephan, Johannes. 'Aspekte Des Tamaddun Als Formen Des Säkularen: Eine Untersuchung Des Arabischen Zivilisationskonzepts Im Werk von Fransīs Marrāš (1835-1874)’. Masters thesis, Universität Bern, 2011.

Storrs, Ronald. Orientations. London: Nicholson \& Watson, 1943.

Strauss, Johann. 'Türkische Übersetzungen Zweier Europäischer Geschichtswerke Aus Muḥammad 'Alī’s Ägypten: Botta's „Storia d'Italia“ et Castéra”s „Histoire de Cathérine ". Edited by Einar von Schüler. Zeitschrift Der Deutschen Morgenländischen Gesellschaft Supplement VII, no. XXIII. Deutscher Orientalistentag (1985) (n.d.): 244-58.

Suleiman, Yasir. The Arabic Language and National Identity: A Study in Ideology. Edinburgh: Edinburgh University Press, 2003.

Suvin, Darko. Metamorphoses of Science Fiction: On the Poetics and History of a Literary Genre. New Haven: Yale University Press, 1979. 
- Other Worlds, Other Seas : Science-Fiction Stories from Socialist Countries. New York: Random House, 1970.

- Russian Science Fiction, 1956-1974: A Bibliography: Original Books, Translated Books, and an Annotated Checklist of Criticism, with an Appendix on Criticism of Russian SF before 1956. Elizabethtown, NY: Dragon Press, 1976.

Sweezy, Paul M., and Maurice Dobb. The Transition from Feudalism to Capitalism. Edited by Rodney Hilton. Foundations of History Library. London: New Left Books, 1976.

'Syria Mission; Value of the Field'. Annual Report of the American Board of Commissoners for Foreign Missions 1844 (1844): 122-27.

Tageldin, Shaden M. Disarming Words: Empire and the Seductions of Translation in Egypt. Berkeley: University of California Press, 2011.

- 'Proxidistant Reading: Toward a Critical Pedagogy of the Nahdah in U.S. Comparative Literary Studies'. Journal of Arabic Literature 43, no. 2-3 (1 January 2012): 227-68.

Ṭahțāwī, Rifā'a Rāfi‘. Al-Ta 'rībāt Al-Shāfiya Li-Murīd Al-Jughrāfiyāa. 2 vols. Bulaq: Dār alMațba'a al-Khudaywiyya, 1250.

—. Anwār Tawfìq Al-Jalīl Bi-Akhbār Miṣr Wa-Tawthīq Banī Ismā ìl. Bulaq, 1285.

, ed. Kitāb Al-Kanz Al-Mukhtār F̄̄ Kashf Al-Arāḍ̄ Wa-Al-Bihārr. 2nd ed. Bulaq: Mațba'at Maktab al-Ṭūbjīyah, 1250.

—. Takhlīṣ Al-Ibrīz F̄̄ Talkhīṣ Bārìz. 1st ed. Būlāq: al-Maṭba a al-Khudaywiyya, 1250.

Ṭahṭāwī, Rifā'a Rāfi' . Kitāb manāhij al-albāb al-Miṣriyya fì mabāhij al-ādāb al- 'așrīya. 2nd ed. Cairo: Maṭba at Sharikat al-Raghā'ib, 1912.

Ṭarābulsī, Fawwāz. A History of Modern Lebanon. London: Pluto, 2007.

- Harīr Wa-ḥad̄̄d, Min Jabal Lubnān Ilā Qanāt Al-Suways. Beirut: Riyāọ al-Rayyis, 2013.

- Șilāt Bilā Waṣl: Mīshāl Shīhā Wa-L-īdiyūlūjiyā Al-Lubnāniyya (Unconnected Links: Michel Chiha and the Lebanese Ideology). Beirut: Riyāḍ al-Rayyis, 1999.

Thackston, Wheeler N. Jr. Murder, Mayhem, Pillage, and Plunder: The History of the Lebanon in the 18th and 19th Centuries by Mikhayil Mishaqa (1800-1873). Albany, NY: SUNY Press, 1988.

Thompson, E. P. ‘An Open Letter to Leszek Kolakowski'. Socialist Register 10 (18 March 1973): 1-100.

—. 'Caudwell'. Socialist Register 14 (1977): 228-76. 
_. 'Eighteenth-Century English Society: Class Struggle without Class?' Social History 3, no. 2 (1978): 133-65.

. 'Romanticism, Moralism and Utopianism: The Case of William Morris'. New Left Review 99 (1976): 83-111.

—. 'The Peculiarities Of The English'. Socialist Register 2 (19 March 1965).

Thomson, Ann. Bodies of Thought: Science, Religion, and the Soul in the Early Enlightenment: Science, Religion, and the Soul in the Early Enlightenment. OUP Oxford, 2008.

Tibawi, Abdul Latif. American Interests in Syria, 1800-1901: A Study of Educational, Literary and Religious Work. Oxford: Clarendon Press, 1966.

Timpanaro, Sebastiano. 'The Pessimistic Materialism of Giacomo Leopardi'. New Left Review 116 (August 1979): 29-50.

Toledano, Ehud R. State and Society in Mid-Nineteenth-Century Egypt. Cambridge: Cambridge University Press, 2003.

Tripp, Charles. Islam and the Moral Economy: The Challenge of Capitalism. Cambridge: Cambridge University Press, 2006.

Venturi, Franco. Utopia and Reform in the Enlightenment. London: Cambridge University Press, 1971.

Volney, C. F. The Ruins, Or, Meditation on the Revolutions of Empires (Paris Translation). New York: Twentieth Century, 1890.

Wallerstein, Immanuel. 'The Ottoman Empire and the Capitalist World-Economy: Some Questions for Research'. Review (Fernand Braudel Center) 2, no. 3 (Winter 1979): 389-98.

Wallerstein, Immanuel, Hale Decdeli, and Resat Kasaba. 'The Incorporation of the Ottoman Empire in the World-Economy'. In The Ottoman Empire and the World-Economy, edited by Huri Islamogu-Inan, 88-97. Cambridge: Cambridge University Press, 1987.

Wartabīt, Yūḥannā. 'Miqdār Ziyādat Al- 'ilm Fī Suriyyā Fī Hādhā Al-Jīl'. In $A$ 'māl AlJam iyya Al-Sūriyya Li-Iktisāb Al-'ulūm Wa-L-Funūn, edited by Buṭus al-Bustānī, 1:10-13. Beirut: American Press, 1852.

Watenpaugh, Keith David. Being Modern in the Middle East : Revolution, Nationalism, Colonialism, and the Arab Middle Class. Princeton: Princeton University Press, 2006.

Wielandt, Rotraud. 'Fransîs Fatḥallâh Marrâshs Zugang Zum Gedankengut Der Aufklärung Und Der Französischen Revolution'. In The Middle East and Europe : Encounters and Exchanges, edited by G. J. H. van Gelder and Ed de Moor, 116-46. Orientations, 
1. Amsterdam: Rodopi, 1992.

Wiet, Gaston. Introduction à La Littérature Arabe. Paris: Maisonneuve et Larose, 1966.

Williams, Raymond. 'Base and Superstructure in Marxist Cultural Theory'. In Culture and Materialism: Selected Essays, 31-49. 11. London: Verso, 2005.

- Culture and Materialism: Selected Essays. London: Verso, 2005.

- Culture and Society 1780-1950. London: Penguin, 1961.

- Keywords: A Vocabulary of Culture and Society. Revised edition. London: Fontana, 1983.

—. Marxism and Literature. Oxford: Oxford University Press, 1977.

—. Modern Tragedy. Peterborough, ON: Broadview Press, 2006.

—. The English Novel from Dickens to Lawrence. St Albans: Paladin, 1974.

—. The Long Revolution. London: Chatto \& Windus, 1961.

- 'Utopia and Science Fiction'. In Culture and Materialism: Selected Essays, 196212. 11. London: Verso, 2005.

- Writing in Society. London: Verso, 1983.

Wolf, Eric R. Europe and the People without History. Berkeley: University of California Press, 1982.

Womersley, David J. 'The Historical Writings of William Robertson'. Journal of the History of Ideas 47, no. 3 (1986): 497-506.

Wood, Ellen Meiksins. 'The Non-History of Capitalism'. Historical Materialism 1, no. 1 (1997): 5-21.

- 'The Question of Market Dependence'. Journal of Agrarian Change 2, no. 1 (2002): $50-87$.

Worringer, Renée. Ottomans Imagining Japan: East, Middle East, and Non-Western Modernity at the Turn of the Twentieth Century. Basingstoke: Palgrave Macmillan, 2014.

Zachs, Fruma. 'Building a Cultural Identity: The Case of Khalil Al-Khuri'. In From the Syrian Land to the States of Syria and Lebanon, edited by Thomas Philipp and Christoph Schumann, 27-39. Beirut: Ergon in Kommission, 2004.

- 'Cultural and Conceptual Contributions of Beiruti Merchants to the Nahda'. Journal of the Economic and Social History of the Orient 55, no. 1 (2012): 153-82. 
—. 'The Beginning of Press Advertising in 19th Century Beirut: Consumption, Consumers and Meanings'. In The Economy As an Issue in the Middle Eastern Press, edited by Gisela Procházka-Eisl and Martin Strohmeier, 187-202. Münster: LIT Verlag, 2008.

- The Making of a Syrian Identity: Intellectuals and Merchants in Nineteenth Century Beirut. Leiden: Brill, 2005.

Zachs, Fruma, and Sharon Halevi. 'From Difā' Al-Nisā' to Mas'alat Al-Nisā' in Greater Syria: Readers and Writers Debate Women and Their Rights, 1858-1900'. International Journal of Middle East Studies 41, no. 4 (2009): 615-33.

Zaydān, Jurjī. Tārīkh Ādāb Al-Lugha Al- 'Arabiyya. Vol. 4: al-Nahḍa al-Akhīra. 4 vols. Cairo: Dār al-Hilāl, 1914.

Zolondek, Leon. 'Al-Tahtawi And Political Freedom'. The Muslim World 54, no. 2 (1964): 90-97.

_. 'Ash-Sha' $b$ in Arabic Political Literature of the 19th Century'. Die Welt Des Islams 10, no. 1 (1965): 1-16.

—. 'The French Revolution in Arabic Literature of the Nineteenth Century'. Muslim World 57, no. 3 (1967).

Zubaida, Sami. 'Exhibitions of Power'. Economy and Society 19, no. 3 (1990): 359-75. 